\title{
WestVirginiaUniversity
}

THE RESEARCH REPOSITORY @ WVU

Graduate Theses, Dissertations, and Problem Reports

2014

\section{Floodplain Mapping in Response to Surface Mine Reclamation}

Erin E. O'Leary

Follow this and additional works at: https://researchrepository.wvu.edu/etd

\section{Recommended Citation}

O'Leary, Erin E., "Floodplain Mapping in Response to Surface Mine Reclamation" (2014). Graduate Theses, Dissertations, and Problem Reports. 6345.

https://researchrepository.wvu.edu/etd/6345

This Thesis is protected by copyright and/or related rights. It has been brought to you by the The Research Repository @ WVU with permission from the rights-holder(s). You are free to use this Thesis in any way that is permitted by the copyright and related rights legislation that applies to your use. For other uses you must obtain permission from the rights-holder(s) directly, unless additional rights are indicated by a Creative Commons license in the record and/ or on the work itself. This Thesis has been accepted for inclusion in WVU Graduate Theses, Dissertations, and Problem Reports collection by an authorized administrator of The Research Repository @ WVU. For more information, please contact researchrepository@mail.wvu.edu. 
Floodplain Mapping in Response to Surface Mine Reclamation

\author{
Erin E. O’Leary
}

Thesis submitted to the

Benjamin M. Statler College of Engineering and Mineral Resources

At West Virginia University

In partial fulfillment of the requirements for the degree of

\author{
Master of Science \\ In \\ Civil Engineering
}

Dr. Leslie C. Hopkinson, Ph.D., Chair

Dr. John D. Quaranta, Ph.D.

Dr. Antar Jutla, Ph.D.

Department of Civil and Environmental Engineering

\author{
Morgantown, West Virginia
}

2014

Keywords: valley fill, modeling, geomorphic design, surface mine reclamation

Copyright 2014, Erin E. O'Leary 


\section{Abstract \\ Floodplain Mapping in Response to Surface Mine Reclamation}

\section{Erin E. O'Leary}

Surface mining and the associated reclamation cause changes in land use and land cover. This change can affect the hydrologic balance. In some cases, an increase in number and magnitude of flood events is observed both on site and in surrounding areas. This research analyzed the hydrologic effects downstream of a reclaimed surface mine, considering the impact of an alternative reclamation technique. Geomorphic landform design (GLD) is a reclamation method that considers the development mature landform shapes to help create a long-term hydrologic balance. Flood maps were created for the pre-mined condition and compared to maps created for three reclamation conditions: conventional reclamation, GLD (During mining) reclamation, and GLD (Post-mining) reclamation. The valleyfill and study site is located in southern West Virginia. Approximately $2.1 \mathrm{~km}$ of the adjacent downstream channel were evaluated. The study area receives $101.6-127 \mathrm{~cm}$ precipitation annually and has a basin slope range of $0.44-0.56 \mathrm{~m} / \mathrm{m}$. GIS data were used to develop a schematic of the downstream channel. Cross-sections were extracted from a triangulated irregular network (TIN) developed from 1/9arc-second elevation data. These geometric data and projected stormflow hydrographs for seven storm events were used to develop both steady and unsteady flow 1-D hydraulic models (HECRAS). The resulting water surface elevations were used to display flooding extents over time resulting from each reclamation condition. For smaller storm events (e.g. 2-yr), conventional reclamation resulted in decreased flooding, and increased flooding was observed for large storm events (e.g. 100-yr, 500-yr). The GLD (During mining) reclamation condition resulted in increased flooding; this increase was mitigated with time. The GLD (Post-mining) results were comparable to those of the pre-mining condition. GLD has the potential to mitigate flooding impacts from surface mining in the long-term in southern West Virginia, but is dependent on properly sized channels and stability of landforms. 


\section{Acknowledgments}

The project described in this publication was supported by Grant/Cooperative Agreement Number G12AP20156 from the United States Geological Survey. Its contents are solely the responsibility of the authors and do not necessarily represent the official views of the USGS.

I am deeply grateful to my advisor and committee chair, Dr. Leslie Hopkinson, for providing the research opportunity and giving excellent guidance throughout this project. I would like to thank both Dr. John Quaranta and Dr. Antar Jutla for providing their time and being on my committee. I would also like to thank Allison Sears and Michael Snyder for their previous work on geomorphic landform design which contributed to my research.

I would also like to express my gratitude to my family and friends who have provided support and encouragement. 


\section{Table of Contents}

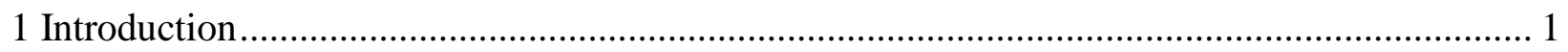

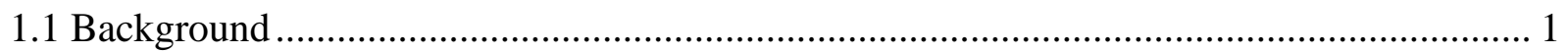

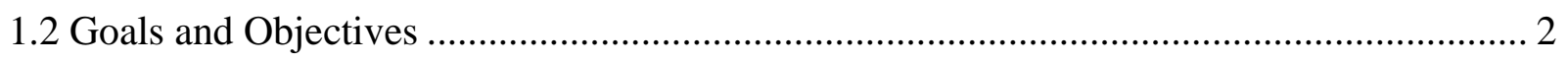

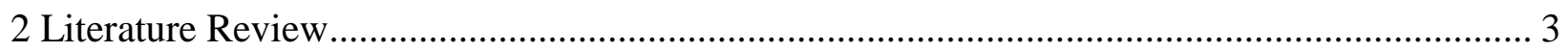

2.1 Techniques and Development ...................................................................................... 3

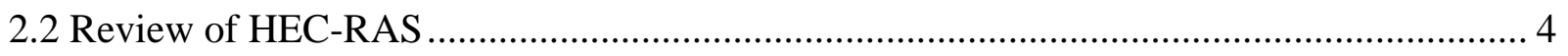

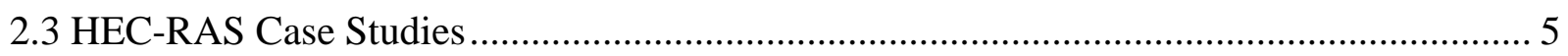

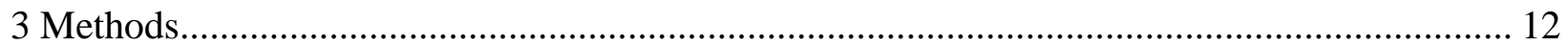

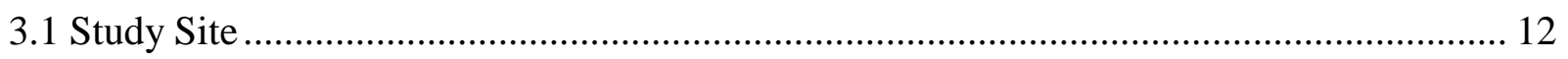

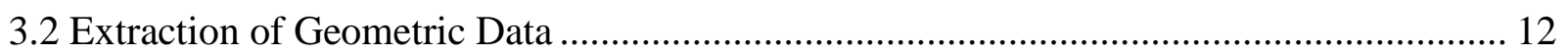

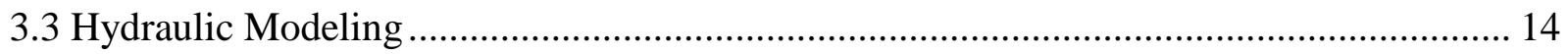

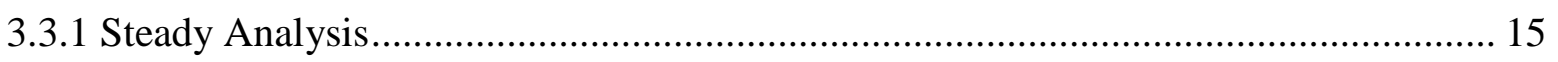

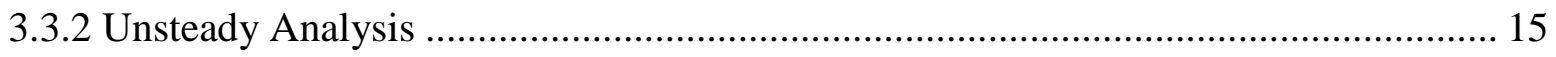

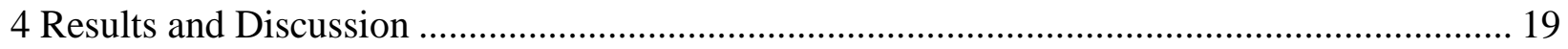

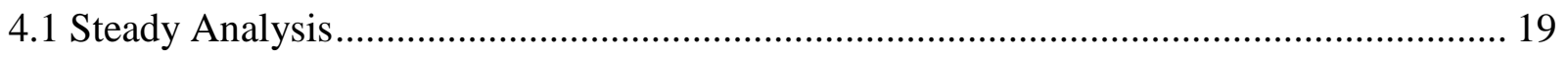

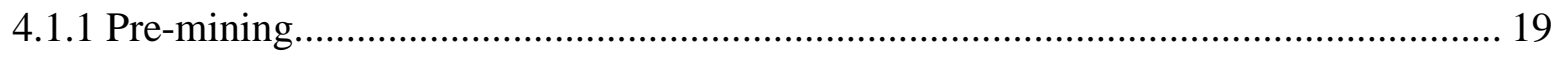

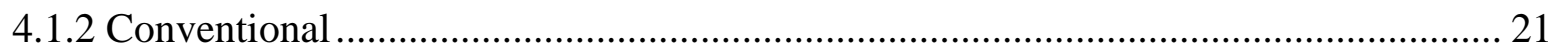

4.1.3 GLD (During mining) ........................................................................................ 22

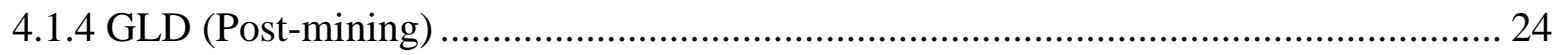

4.1.5 Comparison of Reclamation Designs to Pre-mined Condition.................................... 25

4.2 Unsteady Analysis ………………………………….............................................. 29

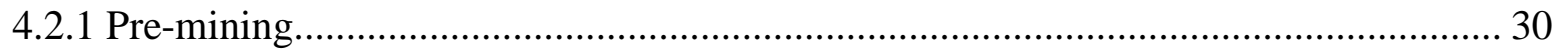

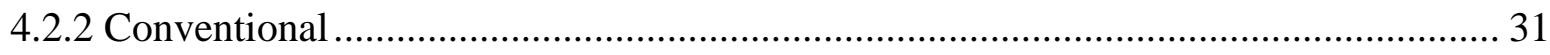

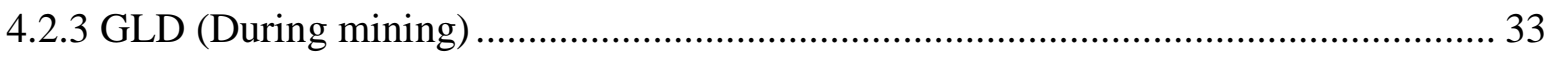

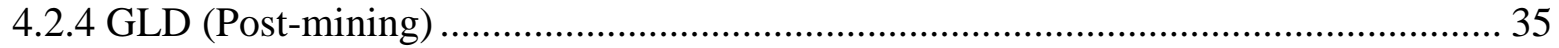

4.2.5 Comparison of Reclamation Designs to Pre-mined Condition..................................... 37

4.3 Comparison of Steady and Unsteady Analysis ............................................................. 43

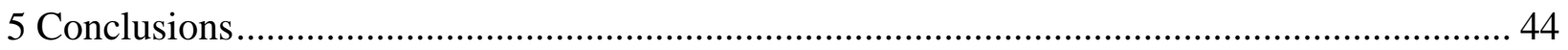

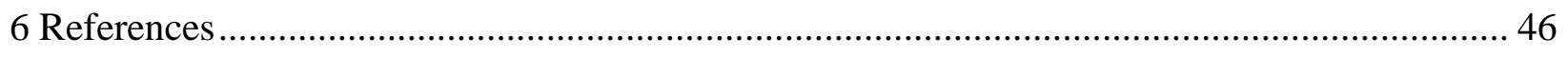

Appendix A - Maps from Unsteady Storms 5-, 10-, and 25-yr Storm Events ............................. 49 


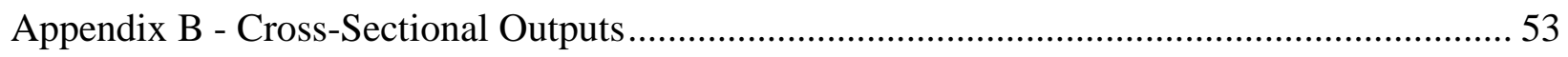

Appendix C - Steady Longtudinal Profiles, 2-, 100-, and 500-yr........................................ 117 


\section{Table of Figures}

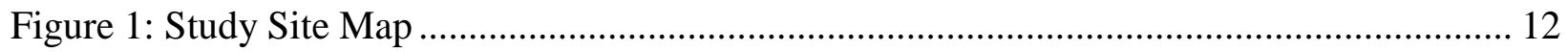

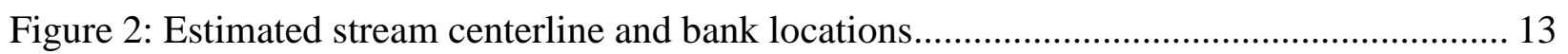

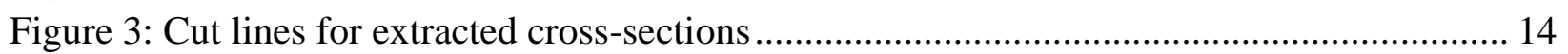

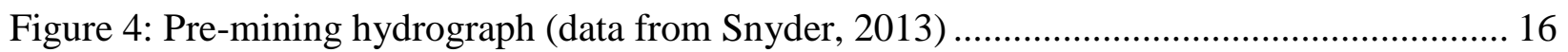

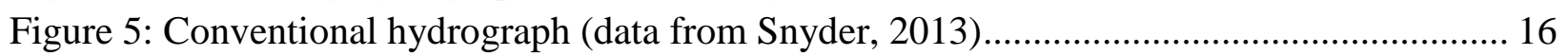

Figure 6: GLD (During mining) hydrograph (data from Snyder, 2013)...................................... 17

Figure 7: GLD (Post-mining) hydrograph (data from Snyder, 2013) ...................................... 17

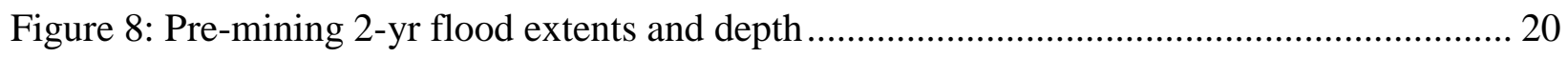

Figure 9: Pre-mining 100-yr flood extents and depth ............................................................... 20

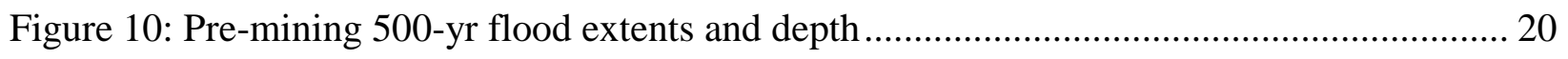

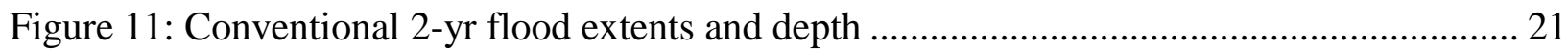

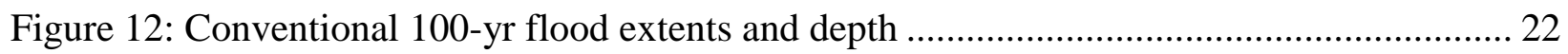

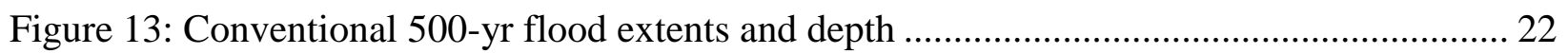

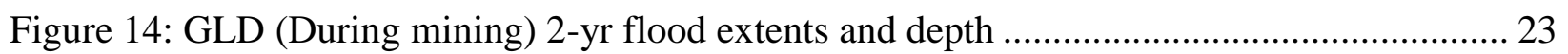

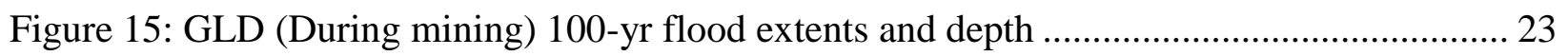

Figure 16: GLD (During mining) 500-yr flood extents and depth .............................................. 23

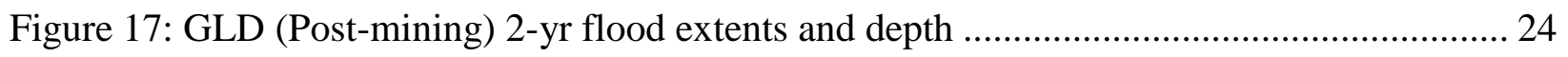

Figure 18: GLD (Post-mining) 100-yr flood extents and depth .................................................. 25

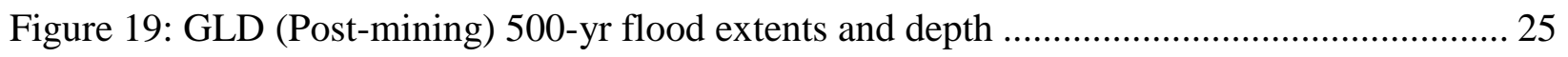

Figure 20: Pre-Mining 2-yr unsteady max water level flood extents and depth........................... 30

Figure 21: Pre-Mining 50-yr unsteady maximum water level flood extents and depth ................ 31

Figure 22: Pre-Mining 100-yr unsteady maximum water level flood extents and depth .............. 31

Figure 23: Pre-Mining 500-yr unsteady maximum water level flood extents and depth .............. 31

Figure 24: Conventional 2-yr maximum unsteady flood extents and depth................................ 32

Figure 25: Conventional 50-yr maximum unsteady flood extents and depth .............................. 33

Figure 26: Conventional 100-yr maximum unsteady flood extents and depth ............................. 33

Figure 27: Conventional 500-yr maximum unsteady flood extents and depth ............................. 33

Figure 28: GLD (During mining) 2-yr maximum unsteady flood extents and depth .................... 34

Figure 29: GLD (During mining) 50-yr maximum unsteady flood extents and depth .................. 34

Figure 30: GLD (During mining) 100-yr maximum unsteady flood extents and depth ................ 35

Figure 31: GLD (During mining) 500-yr maximum unsteady flood extents and depth................ 35

Figure 32: GLD (Post-mining) 2-yr maximum unsteady flood extents and depth ........................ 36

Figure 33: GLD (Post-mining) 50-yr maximum unsteady flood extents and depth ...................... 36

Figure 34: GLD (Post-mining) 100-yr maximum unsteady flood extents and depth .................... 37

Figure 35: GLD (Post-mining) 500-yr maximum unsteady flood extents and depth .................... 37

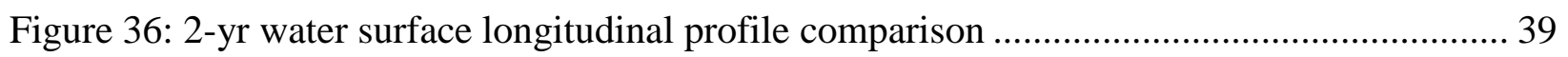

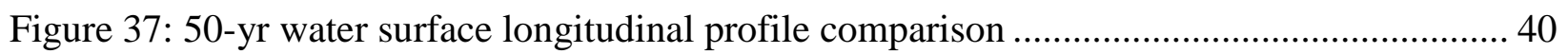

Figure 38: 100-yr water surface longitudinal profile comparison ................................................. 41

Figure 39: 500-yr water surface longitudinal profile comparison ............................................. 42 
Figure 40: Pre-Mining 5-year unsteady maximum water level flood extents and depth ............. 49

Figure 41: Pre-Mining 10-year unsteady maximum water level flood extents and depth........... 49

Figure 42: Pre-Mining 25-year unsteady maximum water level flood extents and depth........... 49

Figure 43: Conventional 5-year maximum unsteady flood extents and depth ......................... 50

Figure 44: Conventional 10-year maximum unsteady flood extents and depth ........................ 50

Figure 45: Conventional 25-year maximum unsteady flood extents and depth ....................... 50

Figure 46: GLD (During mining) 5-year maximum unsteady flood extents and depth .............. 50

Figure 47: GLD (During mining) 10-year maximum unsteady flood extents and depth ............ 51

Figure 48: GLD (During mining) 25-year maximum unsteady flood extents and depth ............ 51

Figure 49: GLD (Post mining) 5-year maximum unsteady flood extents and depth................. 51

Figure 50: GLD (Post mining) 10-year maximum unsteady flood extents and depth................. 52

Figure 51: GLD (Post mining) 25-year maximum unsteady flood extents and depth................ 52

Figure 52: Steady 2-yr water surface longitudinal profile ............................................... 117

Figure 53: Steady 100-yr water surface longitudinal profile ............................................... 117

Figure 54: Steady 500-yr water surface longitudinal profile .............................................. 118

Figure 55: Unsteady 5-yr water surface longitudinal profile............................................. 118

Figure 56: Unsteady 10-yr water surface longitudinal profile ............................................... 119

Figure 57: Unsteady 25-yr water surface longitudinal profile ............................................ 119 


\section{Table of Tables}

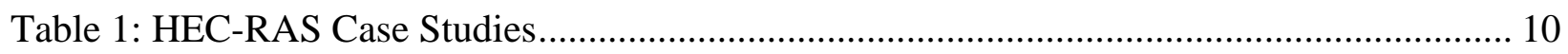

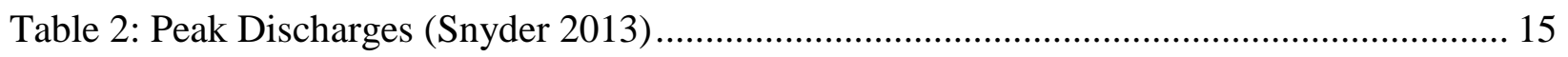

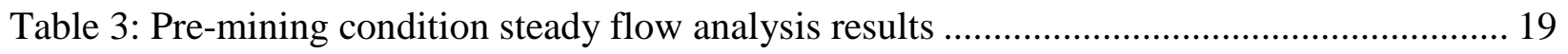

Table 4: Conventional reclamation condition steady flow analysis results ................................... 21

Table 5: GLD (During mining) reclamation condition steady flow analysis results .................... 22

Table 6: GLD (Post-mining) reclamation condition steady flow analysis results ......................... 24

Table 7: Percent change in inundation area between reclamation conditions and pre-mining..... 26

Table 8: Average percent difference between original topography and reclamation designs over all cross-sectional outputs for 2-yr......................................................................................... 27

Table 9: Average percent difference between original topography and reclamation designs over

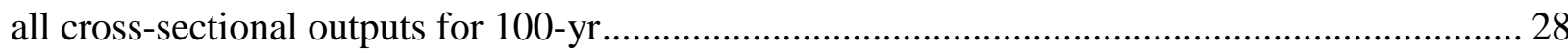

Table 10: Average percent difference between original topography and reclamation designs over

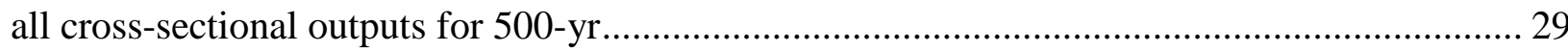

Table 11: Maximum water surface pre-mining condition unsteady flow analysis results ............ 30

Table 12: Maximum water surface conventional condition unsteady flow analysis results.......... 32

Table 13: Maximum water surface GLD (During mining) condition unsteady flow analysis

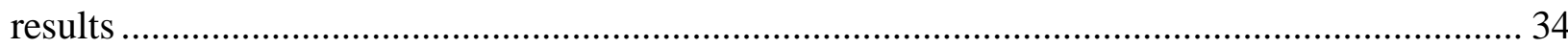

Table 14: Maximum water surface GLD (Post-mining) condition unsteady flow analysis results

Table 15: Percent change in inundation area from maximum water elevations between reclamation conditions and pre-mining

Table 16: Average percent difference between original topography and reclamation designs over

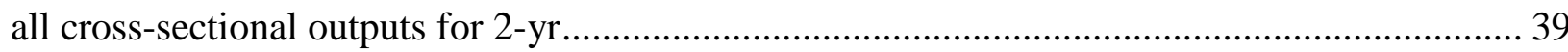
Table 17: Average percent difference between original topography and reclamation designs over

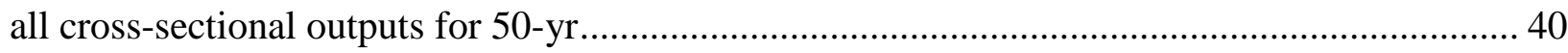
Table 18: Average percent difference between original topography and reclamation designs over all cross-sectional outputs for $100-\mathrm{yr}$

Table 19: Average percent difference between original topography and reclamation designs over

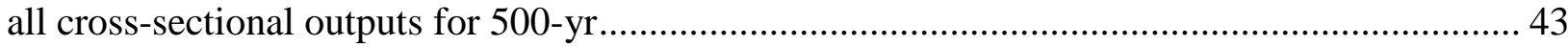

Table 20: Steady Pre-mining cross-sectional properties......................................................... 53

Table 21: Steady Conventional cross-sectional properties ......................................................... 58

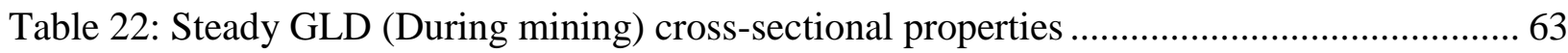

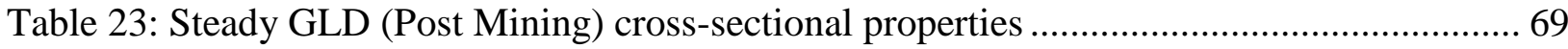

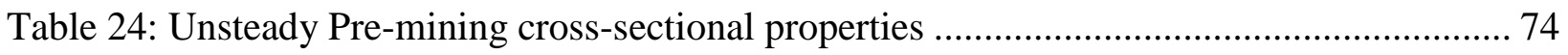

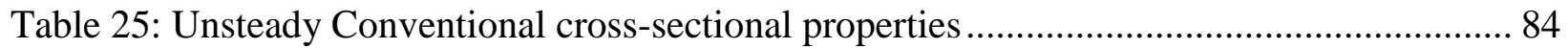

Table 26: Unsteady GLD (During mining) cross-sectional properties ...................................... 95

Table 27: Unsteady GLD (Post mining) cross-sectional properties .......................................... 105 


\section{Introduction}

\subsection{Background}

From 1973 to 2000, the leading cause of land use/land cover (LULC) change in Central Appalachia has been associated with mining, specifically surface mining and its subsequent reclamation (Climate Change Science Program 2003, Ferrari et al. 2009). This method of coal mining dramatically alters topography, vegetation, surface and subsurface properties, and potentially hydrologic response (Phillips 2004). Studies have shown that surface mines and valley fills tend to increase the runoff and decrease the surface detention time of the area (Phillips 2004). Flood magnitudes have been found to increase linearly as the percentage of land affected in the watershed increases. Earthmovers used during reclamation compact the soil and decrease infiltration rates up to 2 orders of magnitude, compared to undisturbed forest. The trends of LULC from surface mining and reclamation are similar to those of urbanization (Ferrari et al. 2009). Changes in hydrologic response associated with urbanization are typically mitigated with stormwater management practices; whereas LULC associated with both active and reclaimed surface mines tend to lack sufficient stormwater management (Phillips 2004).

Studies have also found long-term trends of increased precipitation (Leonard and Law 2004) and precipitation intensity (Pitchford et al. 2012) for the majority of West Virginia. These climate changes also demonstrate an increased number of extreme events that are expected to increase in the future (Kharin and Zwiers 2005). The increase of extreme events in combination with landuse change has potential to greatly increase flooding impacts.

These changes caused by surface mining and associated reclamation can increase the flow output into the headwaters of the adjoining channel and cause flooding. The downstream effects of surface mining and associated reclamation strongly depend on local conditions. Because of this, prediction of outcomes should be done on a case-by-case basis (Phillips 2004, Graf 2001). Floodplain maps are tools used to display flood extents of a channel into the surrounding areas based on water surface elevations of a given storm. Flood extent data can be combined with other data such as maps displaying critical infrastructure (bridges, roads, etc.), buildings (hospitals, etc.), and homes, to analyze the effects of the land use change when various storm events occur (Wurbs and James 2002). This work examines potential flooding impacts resulting from an alternate reclamation technique, geomorphic landform design (Phillips 2004). 


\subsection{Goals and Objectives}

The objective of this research was to explore the potential application of geomorphic landform design (GLD) techniques for surface mine reclamation in southern West Virginia. Specific goals were to model the downstream flooding effects of four different conditions: Premining, conventional reclamation, GLD (During mining) reclamation, and GLD (Post-mining) reclamation. Both cross-sectional properties (area, velocity, maximum depth, etc.) and flood extents were analyzed for various storm events. The conventional reclamation and both GLD reclamation conditions were compared to the pre-mining condition. The steps to achieve these objectives included obtaining geometric data for the study site, developing a hydraulic model, creating flood maps for each condition studied, and analyzing the results to find which reclamation technique to be most comparable to the pre-mining condition. 


\section{Literature Review}

\subsection{Techniques and Development}

The basic process of floodplain delineation involves comparing water surface elevations with ground surface elevations. Observed water level points are marked on a topographic map, and then extended until intersection with a higher elevation contour. The points where water and land intersect are connected together by contour lines to form the extent of inundation (Noman et al. 2001). Development of floodplain delineation typically consists of six steps. First, determine a design flow. This flow can be estimated from a hydrologic model or statistical analysis. Then acquire channel geometry data of the study area. A hydraulic model is then developed using the previously established design flow and channel geometry data to compute water surface elevations and associated hydraulic parameters. The resulting water surface elevations are mapped to create a water level surface. Water depth is then determined by subtracting the ground surface elevations from the water surface elevations. The areas with positive values result in the flood inundation map (Merwade et al. 2008, Noman et al. 2001).

Manually delineating inundated areas on topographic maps can be a tedious and timeconsuming process (Noman et al. 2001, Yang et al. 2006). Developments in linking hydraulic modeling and GIS have led to more sophisticated methods in floodplain mapping. Hydraulic modeling parameters can be extracted from a digital terrain model (DTM) and then imported into the hydraulic model. Output from the hydraulic model is then processed for display and analysis in GIS (Noman et al. 2001, Tate et al. 2002, Merwade et al. 2008).

Multiple features influence the accuracy of floodplain delineation due to uncertainties from the design flow, terrain data, hydraulic model, and mapping techniques (Yang et al. 2006, Merwade et al. 2008). The most important attribute of the modern floodplain delineation process is the accuracy and resolution of the DTM (Casas et al. 2006). Light detection and ranging (LiDAR) is commonly used as a source of topographic data for developing DTMs, although it cannot penetrate the water surface (Merwade et al. 2005) and generally overestimates inundation extent predictions compared to predictions based on surveyed data (Shatnawi and Goodall 2010). Casas (2006) assessed various DTMs developed from three different altimetric sources (GPS survey and bathymetry, LiDAR, and vectoral cartography (1:5000 scale)) for accuracy and cost- 
effectiveness in hydraulic modeling of floods. The study found LiDAR (as the only elevation data source) as a suitable source for obtaining channel parameters and floodplain topography, especially in hydraulic modeling. The addition of surveyed points can improve DTMs developed by LiDAR.

\subsection{Review of HEC-RAS}

In the U.S., HEC-RAS is commonly used for floodplain mapping (Noman et al. 2001, Tate et al. 2002, Knebl et al. 2005, Merwade et al. 2008, Shatnawi and Goodall 2010). HECRAS is a one-dimensional hydraulic modeling software developed by the U.S. Army Corps of Engineers, and is the successor of HEC-2 (Yang et al. 2006). The primary function of HEC-RAS is to calculate water surface elevations for observed flow or routed hydrograph data (USACE, 2010A). Using geometric data input by the user, HEC-RAS has the capabilities to run river analysis for steady flow, unsteady flow, sediment transport, and water quality. (USACE 2010B, Shatnawi and Goodall 2010)

Boundary conditions are necessary for establishing starting water surface at the ends of the river system (upstream and downstream). The boundary conditions required depend on type of flow being analyzed. For steady flow data, the downstream boundary condition is required for subcritical flow analysis, upstream boundary condition for supercritical flow analysis, and both upstream and downstream boundary conditions are required for mixed flow regime calculations. For unsteady flow, both upstream and downstream boundary conditions are required. Internal boundary conditions can also be input as needed (USACE, 2010B).

The steady flow analysis component of HEC-RAS is intended to compute water surface profiles for steady gradually varied flow. Other outputs generated by HEC-RAS steady flow simulations include velocity, flow area, and top width (Shatnawi and Goodall 2010). It is capable of modeling subcritical, supercritical, and mixed flow water surface profiles. Manning's equation is used for these calculations, except around bridge piers, at river confluences, and hydraulic jumps where the momentum equation is used. Hydraulic structures such as bridges, culverts, and weirs, can be incorporated into the computational data (USACE 2010B).

The unsteady flow analysis component is similar to the steady flow analysis in that it computes flow data for a full network of open channels, can model various flow conditions, and 
can incorporate hydraulic structures into the simulation. However, the unsteady flow analysis is designed to complete analysis for systems where flow characteristics change over time. Capabilities unique to the unsteady flow analysis component include dam break analysis, levee breaching and overtopping, pumping stations, navigation dam operations, and pressurized pipe systems (USACE 2010B).

The sediment transport component of HEC-RAS is designed to simulate scour and deposition in channels over moderate time periods. The model simulates long-term trends of scour and deposition in a channel resulting from modifying channel geometry or flow characteristics. The sediment transport component can be used to evaluate deposition in reservoirs, evaluate sedimentation in fixed channels, predict the influence of dredging on the rate of deposition, and estimate the maximum possible scour during large flood events (USACE 2010B).

The water quality analysis component is designed to perform environmental analysis of rivers and streams. The analyses included in this component are dissolved nitrogen, dissolved phosphorus, dissolved oxygen, and carbonaceous biological oxygen demand (USACE 2010B).

A major deficiency of HEC-RAS is that the simulated water surface elevation data cannot be transferred directly to topographic maps. However, the HEC-RAS channel network model supports the importation and exportation of GIS data. Other benefits include quick and simple cross-section interpolation and 3D view of river reach and cross-section data (Yang et al. 2006).

\subsection{HEC-RAS Case Studies}

The following section examines case studies that incorporated HEC-RAS for analysis. Descriptions of major objectives, data needs, and data sources are summarized in Table 1. HECRAS was used to model reservoir storage, assess different types of river morphological data, assess a potential dam breach, develop a new method for real-time flood management in riverreservoir systems, demonstrate a 1-D jokulhlaup simulation, determine flood frequency, quantify hydrogeomorphic processes that influence alluvial gully erosion along a fluvial megafan, and compute water levels in a channel network (Owusu et al. 2013, Saleh et al. 2013, Yochum et al. 2008, Malekmohammadi et al. 2010, Alho and Aaltonen 2008, Maingi and Marsh 2002, Shellberg et al. 2013, Knebl et al. 2005) . From the case studies, it is shown that when channel 
cross-sectional data is unavailable, cross-sections can be created from high resolution DEMs (Knebl et al. 2005, Yochum et al. 2008, Owusu et al. 2013, Shellberg et al. 2013).

Owusu et al. (2013) completed a case study in the Dzorwulu basin in Accra, Ghana simulating the incorporation of reservoir storage to analyze the effects on the reduction of flood peaks and volume in urban areas. Longitudinal and cross-sectional channel characteristics were determined from a field survey, and combined with a TIN model to establish surface elevations. A DEM from the Global Land Cover Facility website was also incorporated to georeferenced the data to the basin. A derived inflow flood hydrograph was used as the hydrology input. The study found that a reservoir-storage approach could be a good alternative for flood hazard reduction. The simulated reservoir resulted in a $45.45 \%$ reduction in flood peak and $38.50 \%$ reduction in inundation depths. It was also noted the use of HEC-RAS and HEC-GeoRAS were useful in flood studies and simplified producing useful results.

A study conducted by Saleh et al. (2013) assessed how various types of river morphological data affect a 1D Saint-Venant hydraulic model (HEC-RAS): mainly when surveyed cross-sections are not available. An Eau-Dyssee hydrologic model was used to simulate lateral inflows, which was then used as an internal boundary condition for the HECRAS model. An observed mean daily discharge hydrograph was used as the upstream boundary condition, and a rating curve based on discharge measurements and observed water levels was used as the downstream boundary condition. Morphological data of the study reach was readily available and consisted of 20 surveyed cross-sections with distances varying from $1 \mathrm{~km}$ to 10 $\mathrm{km}$. Six geometry scenarios were tested, varying the number of surveyed cross-sections used, linearly interpolating bed levels, and using different cross-sectional shapes. The simulated water levels and discharges for the six geometry scenarios were compared to the observed water levels and discharge of the original geometry. The study found that simulated water levels are impacted more by the longitudinal description of bed level profiles than shape of cross-sections. River bed geomorphological irregularities influence the simulated water levels, particularly during low flows. It was also found that model error is likely to decrease as frequency of cross-sections along the reach is increased.

Yochum et al. (2008) conducted a case study testing the accuracy of dam breach predictions. The HEC-RAS unsteady option was used to construct and verify a model of the 
dam failure. Geometric data for the model consisted of 105 cross-sections developed from a 10 $\mathrm{m}$ DEM with additional cross-sections interpolated at $61 \mathrm{~m}$ spacing and eight bridge sections. The downstream boundary condition was normal depth, assuming energy slope equaled valley slope. A breach hydrograph was used as the hydrology input. TR-66 and WinTR-20 hydraulic models were also assessed for this flood event. The study concluded that HEC-RAS produced predicted water levels that were relatively accurate compared to the measured high water marks. However, there were measurable errors due to the geometry extracted from a $10 \mathrm{~m}$ DEM, and higher resolution data was recommended for future studies. WinTR-20 resulted in a reasonably accurate breach attenuation prediction compared to measured high water marks. TR-66, however, did not compare well.

Malekmohammadi et al. (2010) presented a study for a river-reservoir flood management methodology using a combined optimization-simulation approach. The unsteady option in HECRAS was used for the flood inundation modeling and damage estimation portion of the study. The geometric data consisted of 129 cross-sections from a DEM representing the flood plain topography. Arcview GIS was used to combine various layers of geographic information as well as data from the hydraulic model to visualize and estimate flood damages. A genetic algorithm optimization model was used to construct release hydrographs which were used as the hydrology input in the hydraulic model. Specific boundary conditions, DEM resolution, and other flood plain modeling information were not provided within the text of this case study. The results of the hydraulic model and flood damage estimates were used to develop optimal operating rules for the methodology.

The capability of a 1-D hydraulic model (HEC-RAS) to simulate jokulhlaup inundation is compared to the results of a 2-D finite element model to determine possible limitations from the 1D model in a study by Alho and Aaltonen (2008). The finite element mesh from the 2-D model was converted into a TIN of the floodplain topography. From this, 28 cross-sections with $800 \mathrm{~m}$ spacing were extracted and input into the 1-D hydraulic model. An unsteady flow simulation was completed using an inflow hydrograph as the upstream boundary condition and normal depth $(0.004 \mathrm{~m} / \mathrm{m}$ slope $)$ as the downstream boundary condition. The results of the 1-D and 2-D hydraulic models were compared. The 1D HEC-RAS model was found to generally compare favorably to the 2-D infinite mesh model (Alho and Aaltonen 2008). 
A study by Maingi and Marsh (2002) assessed alterations to the hydraulic regime of the Tana River due to the construction of the Masinga Dam. A portion of the study focused on impacts to riverine forests. The steady module of HEC-RAS was used to compute water surface profiles at peak discharges to determine flood frequency at river sections near 71 vegetation sample plots. Geometric data was obtained from existing surveyed cross-sectional data. Only the downstream boundary condition was needed for analysis due to subcritical flow. Normal depth was used with an energy slope of 0.00033. Initial hydrology input consisted of reference discharges to calibrate the HEC-RAS model. Various discharges were then entered into the calibrated hydraulic model to determine the minimum discharge that would cause inundation of the study area. Results found plots located $1.8 \mathrm{~m}$ or less above dry season water level saw an increased number of days flooded, while plots above $1.8 \mathrm{~m}$ experienced decreased number of days flooded. Mean flood pulse duration from the pre- to post- dam period also declined from 8.2 days to 5.2 days. This study concludes that there were significant changes to the hydrologic regime and these changes will negatively impact the riverine forest in the Tana River basin (Maingi and Marsh 2002).

Shellberg et al. (2013) conducted a study with the goal of quantifying hydrogeomorphic processes affecting alluvial gully erosion along the fluvial megafan of the Mitchell River in Australia. The hydraulic modeling portion of the study was accomplished using the HEC-RAS unsteady module. LiDAR data was used to create DEMs $\left(1 \mathrm{~m}^{2}\right.$ pixel $)$ for each reach. Crosssections and other parameters were extracted using HEC-GeoRAS. The model was calibrated using measured stage-discharge curves. The calibrated model was then used to model local rating curves to model inundation. The flood stage data and hydraulic modeling results showed increased flood duration and floodplain/gully connectivity. This study recommends a strong understanding the physical processes affecting large floodplain river systems for land, river, and restoration management (Shellberg et al. 2013).

A case study by Knebl et al. (2005) presents a methodology to streamline the process of modeling rainfall-runoff relations. HEC-HMS was used as the rainfall-runoff model and provided hydrograph data for use in the hydraulic model (HEC-RAS). The HEC-RAS unsteady module was executed using geometric data extracted for a high resolution DEM to compute water levels in the channel network. The results were combined with GIS to produce flood 
inundation areas and depths. The study demonstrated regional hydrologic modeling incorporating real-time rainfall data and resulted in a complete hydrological and hydraulic model and comprehensive GIS database for the San Antonio River Basin. The methodology presented has strong potential to be successful in regional flood models for other regions of Texas and possibly throughout the nation (Knebl et al. 2005). 
Table 1: HEC-RAS Case Studies

\begin{tabular}{|c|c|c|c|c|c|}
\hline Objectives & $\begin{array}{l}\text { Flow } \\
\text { Classification }\end{array}$ & Geometric Data & Hydrology Input & $\begin{array}{l}\text { Boundary } \\
\text { Conditions }\end{array}$ & Reference \\
\hline $\begin{array}{l}\text { Model potential effects of } \\
\text { incorporating reservoir storage for } \\
\text { reducing flood peaks and volume }\end{array}$ & Unsteady & DEM (size not specified) & Inflow flood hydrographs & $\begin{array}{l}\text { US**: Flow } \\
\text { hydrograph } \\
\text { DS**: * }\end{array}$ & (Owusu et al. 2013) \\
\hline $\begin{array}{l}\text { Evaluate 1-D hydraulic model } \\
\text { sensitivity to various types of river } \\
\text { morphological data }\end{array}$ & Unsteady & Surveyed cross-sections & $\begin{array}{l}\text { Hydrogeological modeling } \\
\text { platform Eau-Dyssée used } \\
\text { to simulate lateral inflows }\end{array}$ & $\begin{array}{l}\text { US: Observed } \\
\text { mean daily } \\
\text { discharge } \\
\text { hydrograph } \\
\text { DS: Rating curve }\end{array}$ & (Saleh et al. 2013) \\
\hline $\begin{array}{l}\text { Assess the potential accuracy of dam } \\
\text { breach inundation predictions } \\
\text { compared to an actual event }\end{array}$ & Unsteady & $\begin{array}{l}\text { 10-m DEM ( } 7.5 \text {-min USGS } \\
\text { quadrangle maps) and } \\
\text { bridge cross-sections }\end{array}$ & $\begin{array}{l}\text { Breach hydrograph } \\
\text { created using the dam } \\
\text { breach option within } \\
\text { HEC-RAS }\end{array}$ & $\begin{array}{l}\text { DS: Normal } \\
\text { depth }\end{array}$ & (Yochum et al. 2008) \\
\hline $\begin{array}{l}\text { Develop a methodology for real-time } \\
\text { flood management in river-reservoir } \\
\text { systems }\end{array}$ & Unsteady & $\begin{array}{l}129 \text { cross-sections (method } \\
\text { not specified) }\end{array}$ & Inflow flood hydrographs & $*$ & $\begin{array}{l}\text { (Malekmohammadi } \\
\text { et al. 2010) }\end{array}$ \\
\hline
\end{tabular}




\begin{tabular}{|c|c|c|c|c|c|}
\hline Objectives & $\begin{array}{l}\text { Flow } \\
\text { Classification }\end{array}$ & Geometric Data & Hydrology Input & $\begin{array}{l}\text { Boundary } \\
\text { Conditions }\end{array}$ & Reference \\
\hline $\begin{array}{l}\text { Demonstrate the capability of 1-D } \\
\text { jokulhlaup simulation and compare } \\
\text { results with a 2-D finite element } \\
\text { model }\end{array}$ & Unsteady & $\begin{array}{l}\text { Nodes of a finite element } \\
\text { mesh converted into TIN } \\
\text { form to extract cross- } \\
\text { sectional data }\end{array}$ & Flow hydrograph & $\begin{array}{l}\text { US: Discharge } \\
\text { hydrograph } \\
\text { DS: Normal } \\
\text { depth }\end{array}$ & $\begin{array}{l}\text { (Alho and Aaltonen } \\
\text { 2008) }\end{array}$ \\
\hline $\begin{array}{l}\text { Determine the frequency of flooding } \\
\text { of vegetation sample plots. }\end{array}$ & Steady & Surveyed cross-section data & $\begin{array}{l}\text { Initial analysis: Gauge } \\
\text { data and known water } \\
\text { surface elevations (for } \\
\text { calibration). } \\
\text { After calibration: } \\
\text { Theoretical discharges } \\
\text { used }\end{array}$ & $\begin{array}{l}\text { DS: Normal } \\
\text { depth }\end{array}$ & $\begin{array}{l}\text { (Maingi and Marsh } \\
\text { 2002) }\end{array}$ \\
\hline $\begin{array}{l}\text { Specify hydrogeomorphic processes } \\
\text { affecting alluvial gully erosion along } \\
\text { the Mitchell River fluvial megafan in } \\
\text { Australia }\end{array}$ & Unsteady & $\begin{array}{l}\text { Extracted cross-sections } \\
\text { and estimated other } \\
\text { geomorphic parameters } \\
\text { from } 1 \mathrm{~m}^{2} \text { pixel DEMs } \\
\text { developed from LiDAR }\end{array}$ & $\begin{array}{l}\text { Discharge and flood } \\
\text { frequency data from river } \\
\text { gauge stations }\end{array}$ & $\begin{array}{l}\text { DS: Normal } \\
\text { depth }\end{array}$ & $\begin{array}{l}\text { (Shellberg et al. } \\
\text { 2013) }\end{array}$ \\
\hline $\begin{array}{l}\text { Develop a framework for regional } \\
\text { scale flood modeling that integrates } \\
\text { NEXRAD Level III rainfall, GIS, and } \\
\text { a hydrological model (HEC- } \\
\text { HMS/RAS) }\end{array}$ & Unsteady & $\begin{array}{l}\text { DEM enhanced by available } \\
\text { cross-sections from the } \\
\text { USGS }\end{array}$ & $\begin{array}{l}\text { Hydrographs developed in } \\
\text { HEC-HMS }\end{array}$ & $*$ & (Knebl et al. 2005) \\
\hline
\end{tabular}

*Not specified.

**US = upstream, DS = downstream 


\section{Methods}

First a conceptual model was developed using GIS data to develop a base map, extract geometric data, and display simulation results for the hydraulic modeling process. Then geometric data of the study reach was extracted from the model and exported into a hydraulic model (HEC-RAS 4.1.0). HEC-RAS was used to run both a steady and unsteady analysis of the inflow data from various reclamation conditions.

\subsection{Study Site}

The study site was an approximately 2.1 kilometer section of a 3rd order stream, located in southern West Virginia named Study Creek for the purposes of this report. The study reach began at the outlet of the unnamed mountain stream carrying the runoff from the mine site to Study Creek, and ended at the junction of Study Creek and the downstream tributary.

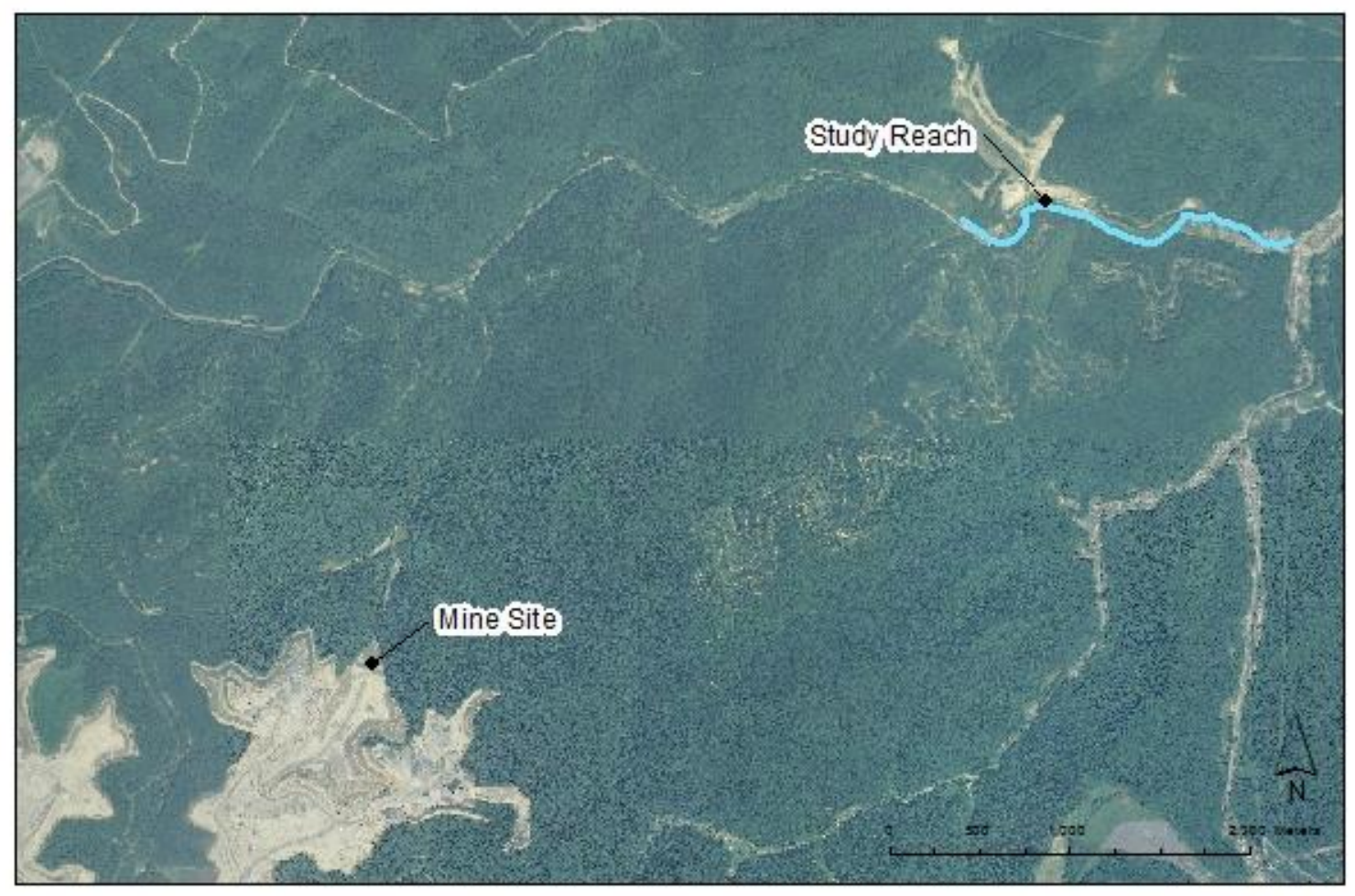

Figure 1: Study Site Map

\subsection{Extraction of Geometric Data}

Geometric data were not available for the study area. Previous studies (Alho and Aaltonen 2008; Owusu et al. 2013; Shellberg at al. 2013; Yochum et al. 2008) have shown that 
extracting information from high quality elevation data is an acceptable alternative when survey data is not available. This method was applied to the study area to obtain geometric data for the hydraulic model. First GIS data were used to create a digital representation of the study area. A Digital Elevation Model (DEM) was produced using 1/9 arcsecond (approximately 3 meters) elevation data from USGS National Elevation georeferenced orthophotos and topographic maps were incorporated into the GIS to assist estimation of stream centerline and left and right bank locations (Figure 2).

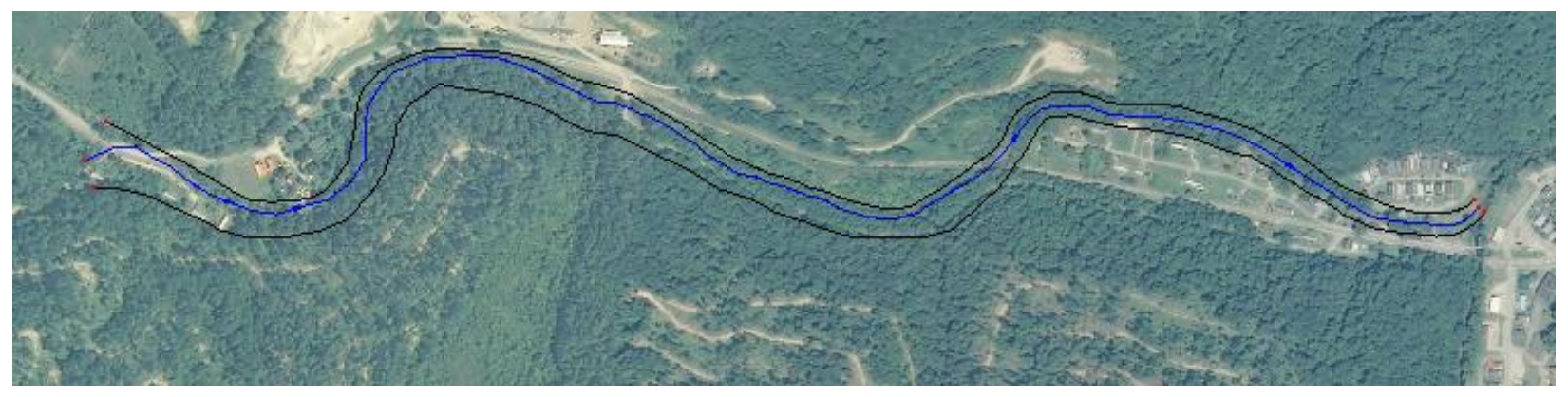

Figure 2: Estimated stream centerline and bank locations

Samuel's equation was used to assist in determining cross-section spacing (Samuels 1989).

$$
\Delta x \leq \frac{0.15 D}{S_{0}}
$$

where, $\Delta x=$ cross-section spacing $(\mathrm{ft}) ; D=$ bankful depth $(\mathrm{ft})$; and $S_{0}=$ stream slope $(\mathrm{ft} / \mathrm{ft})$.

Flood depths for the largest storm (500-yr) and smallest storm (2-yr) were input into the equation as " $\mathrm{D}$ " instead of bankful depth, due to the modeling of larger storm events. This resulted in a cross-sectional spacing range of 32 to $83 \mathrm{~m}$. This range was used as a starting point, and crosssections were added and altered as needed. The final model resulted in 52 cross-sections.

Cut lines for the cross-sections were drawn perpendicular to the contours and estimated centerline and bank locations (Figure 3). Spacing varied depending on the characteristics of certain locations in the reach. Cross-sections typically need to have smaller spacing where 
channels bend or the channel geometry varies significantly, whereas straighter and more uniform sections of a channel can have a greater cross-sectional spacing.

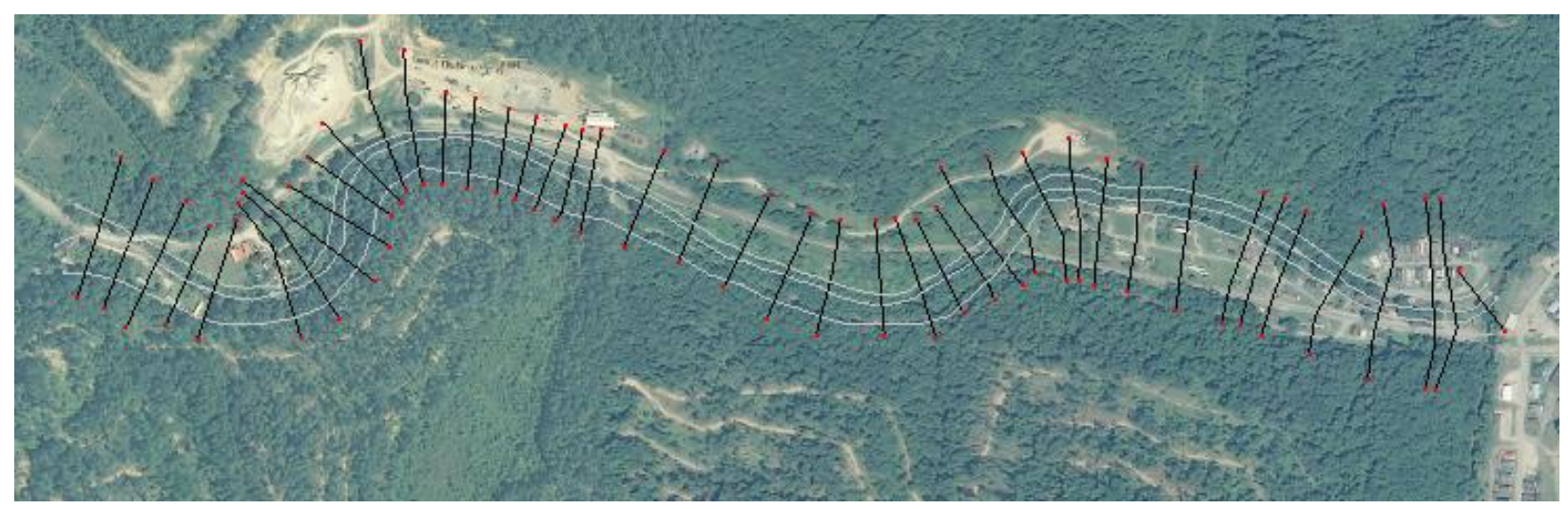

Figure 3: Cut lines for extracted cross-sections

Cross-sectional data were extracted from the locations of the cut lines and exported into a hydraulic model (HEC-RAS 4.1.0).

\subsection{Hydraulic Modeling}

Four reclamation conditions were used for analysis: Pre-mining, Conventional, Geomorphic Landform Design (During mining), and Geomorphic Landform Design (Postmining). The pre-mining condition analyzed the effects of runoff from the undisturbed topography at the mine site location.

The conventional reclamation condition is an Approximate Original Contour (AOC) variation. The design consists of a flat mountain top with a valley fill at the headwaters of the watershed, sedimentation ditches to redirect flow to NPDES permit points, $20 \mathrm{ft}$. horizontal benches every 50 vertical feet, and groin ditches on either side of the valley fill to redirect flow away from the valley fill face (Sears 2012, Snyder 2013).

The GLD (During mining) and GLD (Post-mining) reclamation conditions consisted of the same topography but represents two points in time after reclamation. The GLD reclamation design incorporated geomorphic landform design techniques. Man-made sub-basins were used to direct flow to pre-established stream beds. The stream beds were designed to carry runoff to the original stream (Snyder 2013). The GLD (During mining) reclamation condition analyzed the runoff effects during mining and had a CN of 84. The GLD (Post-mining) condition modeled the 
short term (<5 years) post-mining runoff effects of the GLD design and had a CN of 67. Hydrographs for each condition were developed by Snyder (2013).

\subsubsection{Steady Analysis}

Three storms were used for the steady analysis of each reclamation condition: 2-year, 100-year, and 500-year. Necessary data for a steady hydraulic model are geometric data, steady flow data, and boundary conditions (USACE, 2010b). Geometric data were extracted from GIS data, as described in the previous section. Peak discharges from the hydrologic model created in a previous study (Snyder, 2013) were used for the steady flow data (Table 2).

Table 2: Peak Discharges (Snyder 2013)

\begin{tabular}{llll}
\hline & \multicolumn{3}{c}{ Peak Discharge, cms (cfs) } \\
& \multicolumn{1}{c}{ 2-year } & \multicolumn{1}{c}{ 100-year } & 500-year \\
\hline Pre-mining & $2.94(104)$ & $24.0(849)$ & $35.6(1256)$ \\
Conventional & $0.818(28.9)$ & $33.1(1168)$ & $46.1(1628)$ \\
GLD (During mining) & $19.4(686)$ & $62.4(2205)$ & $91.3(3225)$ \\
GLD (Post-mining) & $2.97(105)$ & $22.5(795)$ & $36.2(1383)$ \\
\hline
\end{tabular}

Steady analysis in HEC-RAS only requires one boundary condition. Normal depth was used as the downstream boundary condition, which required entering the downstream slope for normal depth computation. A slope of 0.0144 that was measured from GIS was used for this input.

A steady flow analysis with a subcritical flow regime was performed. The resulting water surface elevations were imported into the conceptual model. The water surface elevation data were delineated to display the resulting flood extents for each storm event. This process was repeated for each of the four reclamation conditions.

\subsubsection{Unsteady Analysis}

Seven storm events were modeled for the unsteady flow analysis: 2-, 5-, 10-, 25-, 50-, 100-, and 500-year. The extracted geometric data used in the steady analysis was also used for the unsteady. The required unsteady flow data were initial conditions, upstream, and downstream boundary conditions (USACE 2010b). 
Hydrographs (Figures 4-7) developed from a previous study (Snyder 2013) were input as the upstream boundary condition with a 6-minute time step. Normal depth was used as the downstream boundary condition using a slope of 0.0144 .

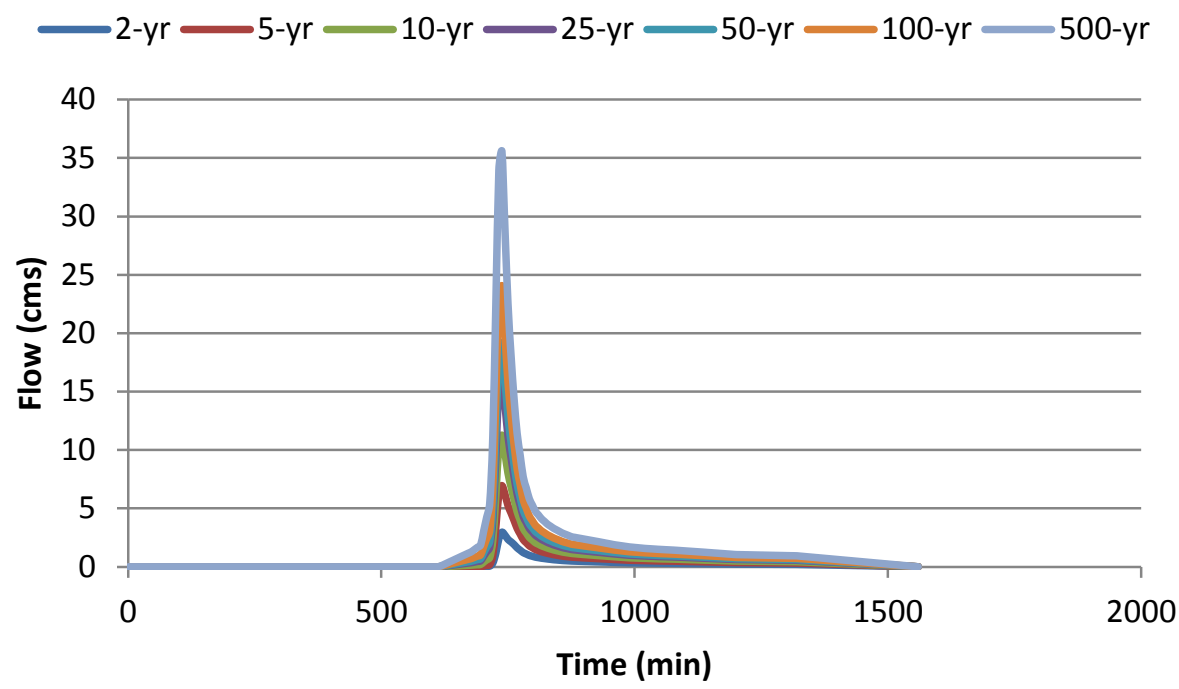

Figure 4: Pre-mining hydrograph (data from Snyder, 2013)

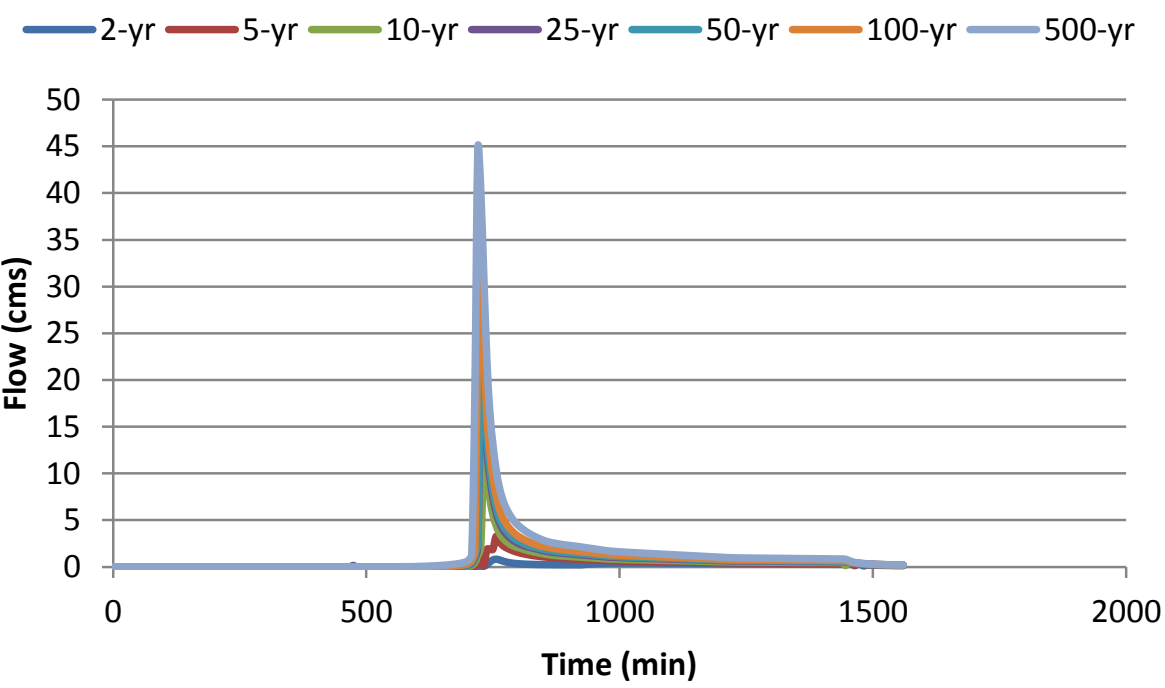

Figure 5: Conventional hydrograph (data from Snyder, 2013) 


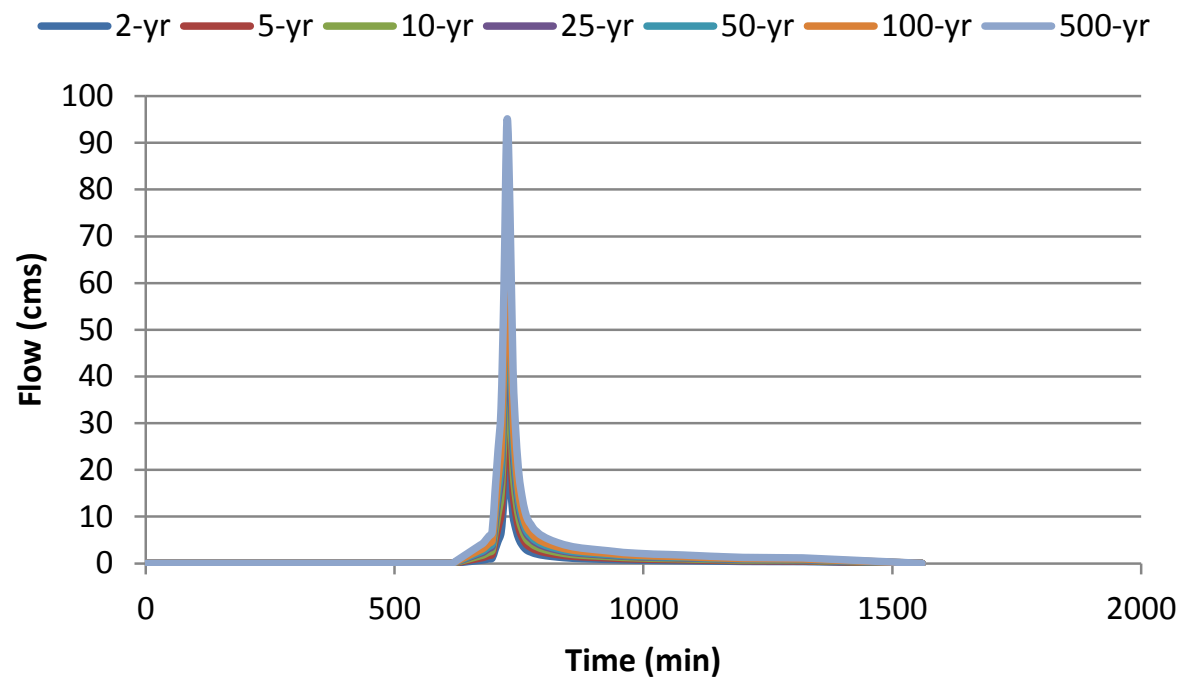

Figure 6: GLD (During mining) hydrograph (data from Snyder, 2013)

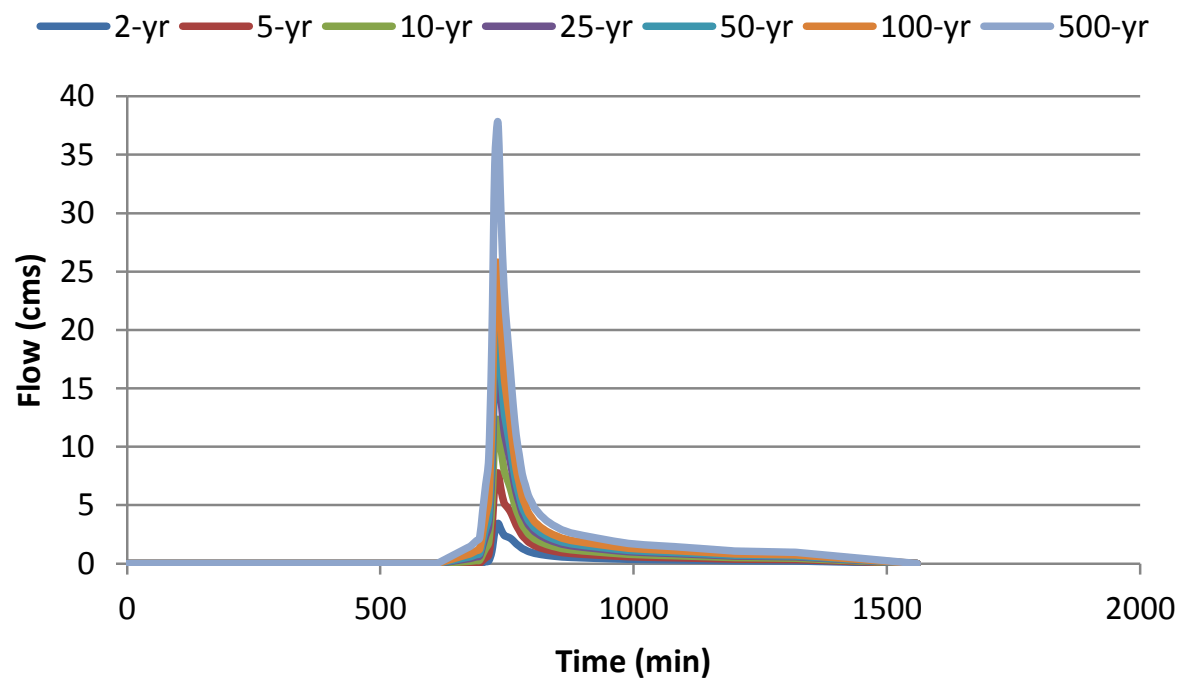

Figure 7: GLD (Post-mining) hydrograph (data from Snyder, 2013)

The study reach was at an ungauged location; therefore the initial condition flow data was unknown. The baseline water depth was estimated using streamflow statistics with the assistance of the USGS National Streamflow Statistics Program 6.0 (USGS 2011). The estimated depth was modeled onto a sample cross-section to determine the cross-sectional area and wetted 
perimeter. This information was then input into Manning's equation to determine the estimated baseline flow. The calculated flow $\left(0.844 \mathrm{~m}^{3} / \mathrm{s}\right)$ was used as the initial condition for the unsteady analysis and also added to the inflow hydrograph data.

Once the necessary inputs were acquired, it was found that additional cross-sections were needed to stabilize the unsteady model. Additional cross-sections were interpolated in HECRAS to determine the optimum spacing. Once the spacing and location of the new cross-sections were determined for stabilization, the interpolated cross-sections were replaced with GIS extracted cross-sectional data to provide more accurate information for modeling. The unsteady analysis resulted in water surface levels at 1 hour intervals for a 24-hour period for each storm event as well as the maximum water elevations for each cross-section. The maximum water surface data were then imported back into GIS and used to delineate the flood areas for each modeled storm event. This process was repeated for each of the reclamation conditions. 


\section{Results and Discussion}

\subsection{Steady Analysis}

The water surface elevations and associated cross-sectional results from the hydraulic model are displayed in the following sections. The cross-sectional results are the calculated outputs for each cross-section in the study reach. Tables 3-6 summarize the cross-sectional outputs for each reclamation condition. The flood extents and depths are presented in flood maps for the 2-yr, 100-yr, and 500-yr storm events for the pre-mining and three reclamation conditions (Figures 8-19). The range of flood extents and maximum flood depths are provided in tables for each condition. The results for each reclamation condition are compared to the premining condition. The steady results are then compared to the unsteady results.

\subsubsection{Pre-mining}

The steady flow analysis results for the pre-mining condition are displayed in Table 3 and Figures 8-10. Table 3 presents the total surface area inundated, maximum depth, ranges of flood extents, cross-sectional flow areas, and velocities of the channel.

Table 3: Pre-mining condition steady flow analysis results

\begin{tabular}{cccccc}
\hline $\begin{array}{c}\text { Rainfall } \\
\text { Return } \\
\text { Period } \\
(\mathbf{y r})\end{array}$ & $\begin{array}{c}\text { Flood Extents* } \\
(\mathbf{m})\end{array}$ & $\begin{array}{c}\text { Max. } \\
\text { Depth }(\mathbf{m})\end{array}$ & $\begin{array}{c}\text { Cross-Sectional } \\
\text { Flow Area* } \\
\left(\mathbf{m}^{2}\right)\end{array}$ & $\begin{array}{c}\text { Average } \\
\text { Velocity } \\
(\mathbf{m} / \mathbf{s})\end{array}$ & $\begin{array}{c}\text { Flood } \\
\text { Surface Area } \\
\left(\mathbf{k m}^{2}\right)\end{array}$ \\
\hline 2 & $11.7(6.0-29.7)$ & 0.9 & $4.1(2.1-17.1)$ & 1.1 & 23.0 \\
100 & $21.3(10.1-45.1)$ & 1.9 & $15.7(8.6-53.4)$ & 1.9 & 41.4 \\
500 & $25.8(11.2-55.5)$ & 2.3 & $21.0(11.4-71.2)$ & 2.1 & 48.9 \\
\hline
\end{tabular}

*mean and range in parentheses

The resulting flood extents and depths of the peak flows for the 2-yr, 100-yr, and 500-yr storm events are displayed in Figures 8, 9, and 10. These results will be used to compare the three reclamation conditions: conventional, GLD (Pre-mining), and GLD (Post-mining). 


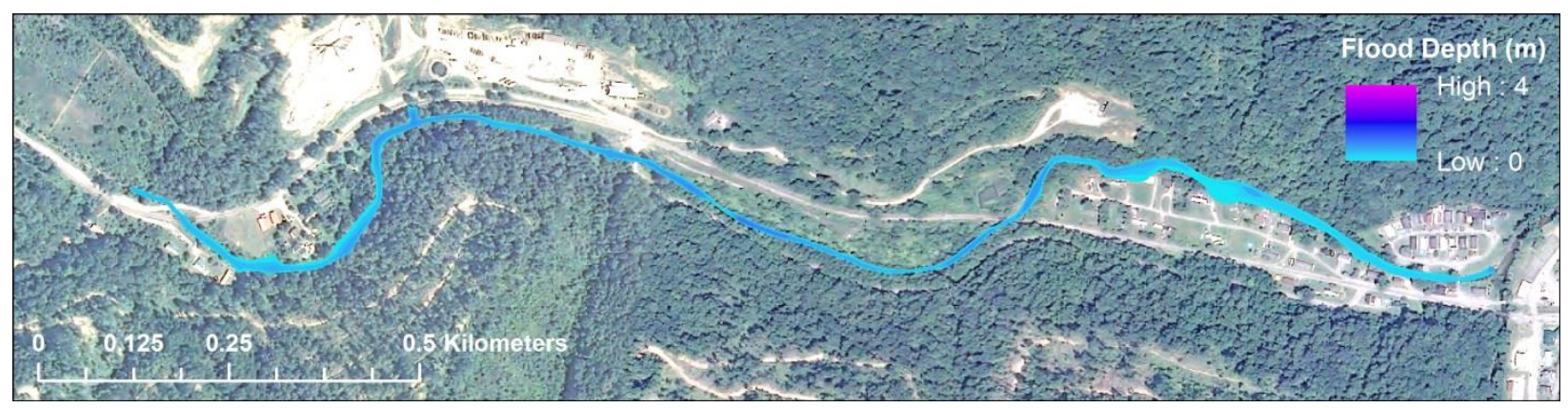

Figure 8: Pre-mining 2-yr flood extents and depth

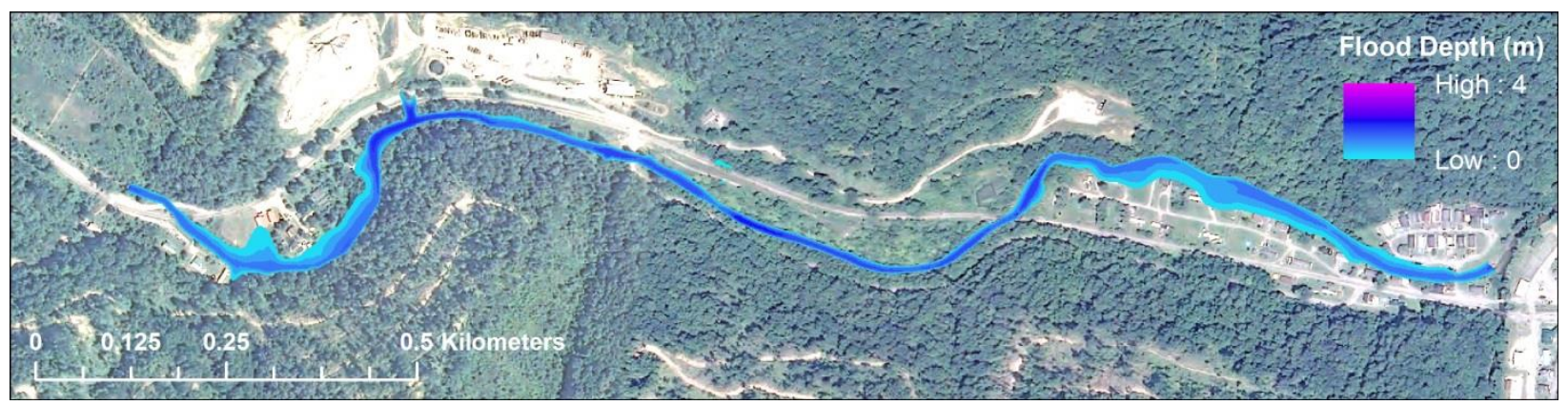

Figure 9: Pre-mining 100-yr flood extents and depth

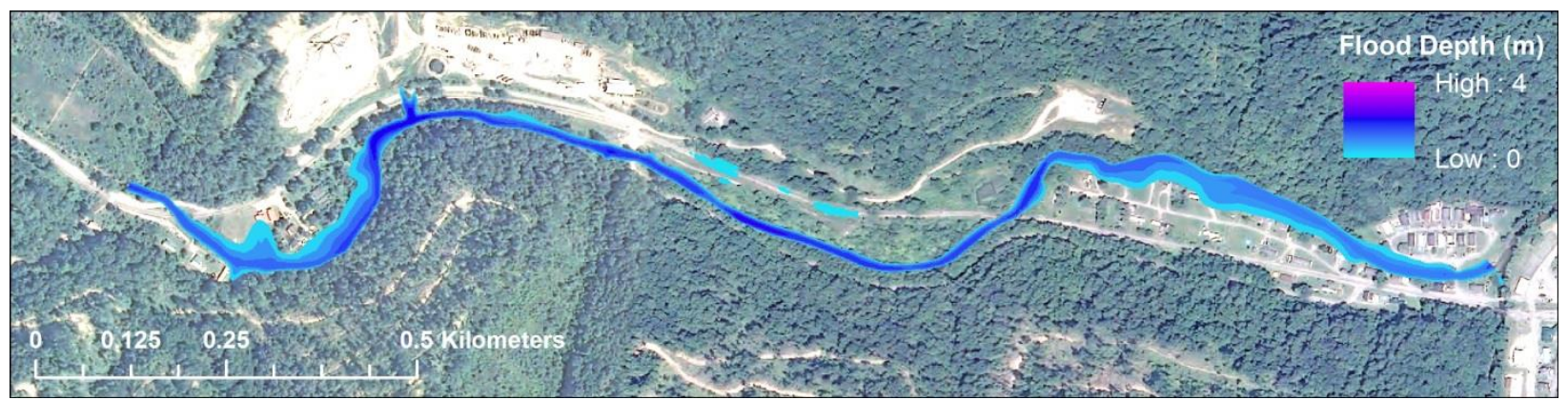

Figure 10: Pre-mining 500-yr flood extents and depth 


\subsubsection{Conventional}

Results of the conventional reclamation steady flow analysis are displayed in Table 4 and Figures 11-13.

Table 4: Conventional reclamation condition steady flow analysis results

\begin{tabular}{cccccc}
\hline $\begin{array}{c}\text { Rainfall } \\
\begin{array}{c}\text { Return } \\
\text { Period } \\
(\mathbf{y r})\end{array}\end{array}$ & $\begin{array}{c}\text { Flood Extents* } \\
(\mathbf{m})\end{array}$ & $\begin{array}{c}\text { Max. } \\
\text { Depth } \\
(\mathbf{m})\end{array}$ & $\begin{array}{c}\text { Cross-Sectional } \\
\text { Flow Area* } \\
\left(\mathbf{m}^{\mathbf{2}}\right)\end{array}$ & $\begin{array}{c}\text { Average } \\
\text { Velocity } \\
(\mathbf{m} / \mathbf{s})\end{array}$ & $\begin{array}{c}\text { Flood } \\
\text { Surface Area } \\
\left(\mathbf{k m}^{\mathbf{2}}\right)\end{array}$ \\
\hline 2 & $9.5(5.1-26.0)$ & 0.7 & $2.3(1.1-10.7)$ & 0.9 & 18.4 \\
100 & $24.7(11.0-53.1)$ & 2.2 & $19.9(10.9-67.3)$ & 2.1 & 47.2 \\
500 & $29.9(11.9-70.2)$ & 2.6 & $25.9(13.8-88.0)$ & 3.4 & 56.4 \\
\hline
\end{tabular}

*mean and range in parentheses

The conventional reclamation resulted in smaller maximum channel depth for the 2 -yr in comparison to the pre-mining conditions. The 100-yr and 500-yr had greater maximum channel depths compared to pre-mining conditions. The 2 -yr depth was reduced by $25 \%$ and the $100-\mathrm{yr}$ and 500-yr depths increased $15 \%$ and $13 \%$, respectively, compared to the pre-mining conditions.

The inundation area covered by the flood events are $18.3 \mathrm{~km}^{2}, 47.1 \mathrm{~km}^{2}$, and $56.4 \mathrm{~km}^{2}$ for the 2-yr, 100-yr, and 500-year events. The inundation area from the $2-\mathrm{yr}$ is $20 \%$ less than the resulting inundation area from the pre-mining conditions 2-yr storm event. The inundation areas for the 100-yr and 500-yr increased by $14 \%$ and $15 \%$ compared to pre-mining conditions.

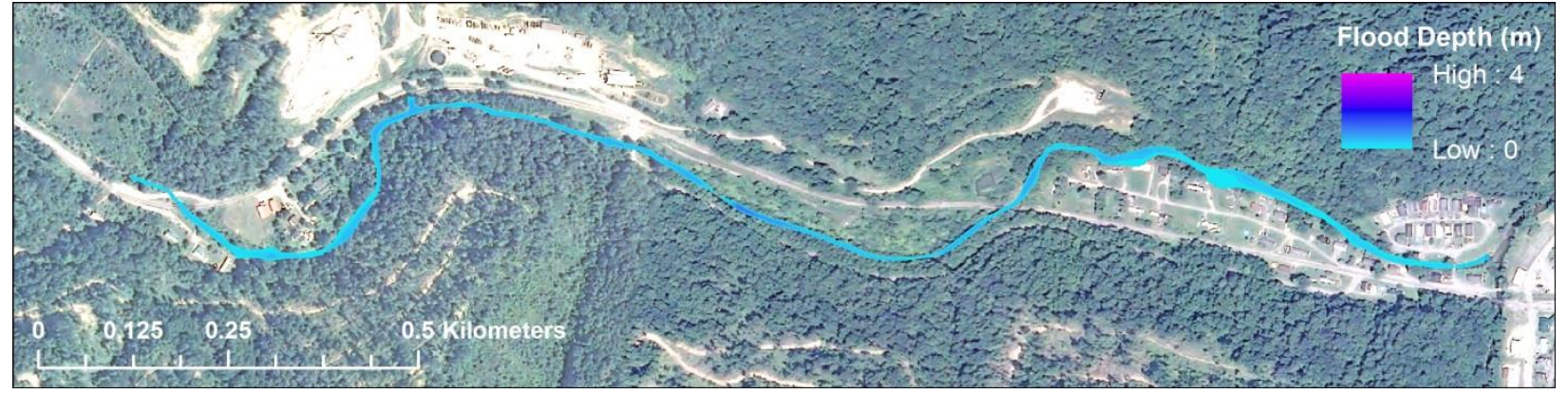

Figure 11: Conventional 2-yr flood extents and depth 


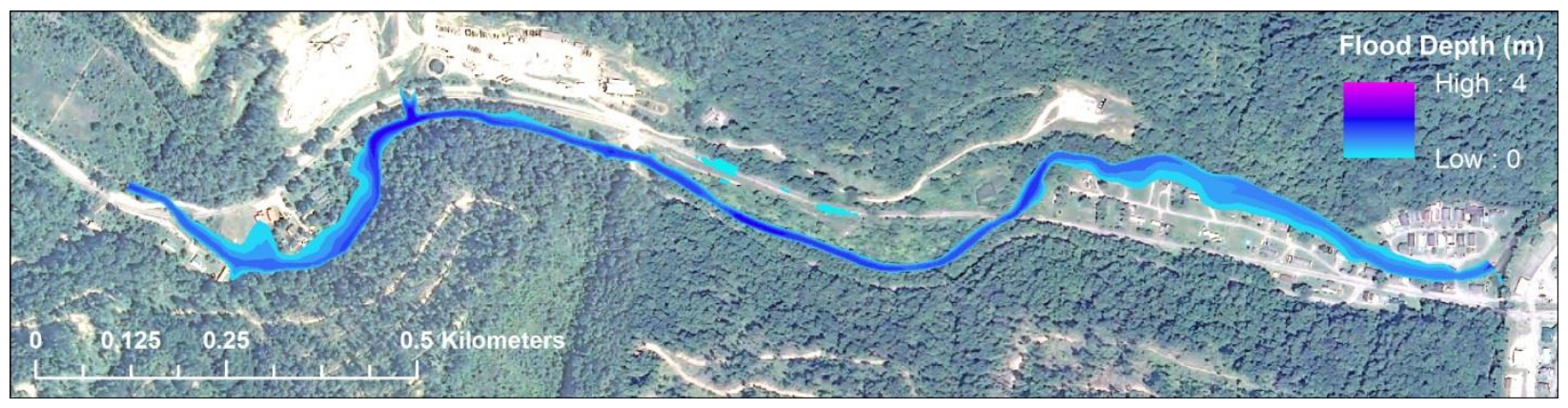

Figure 12: Conventional 100-yr flood extents and depth

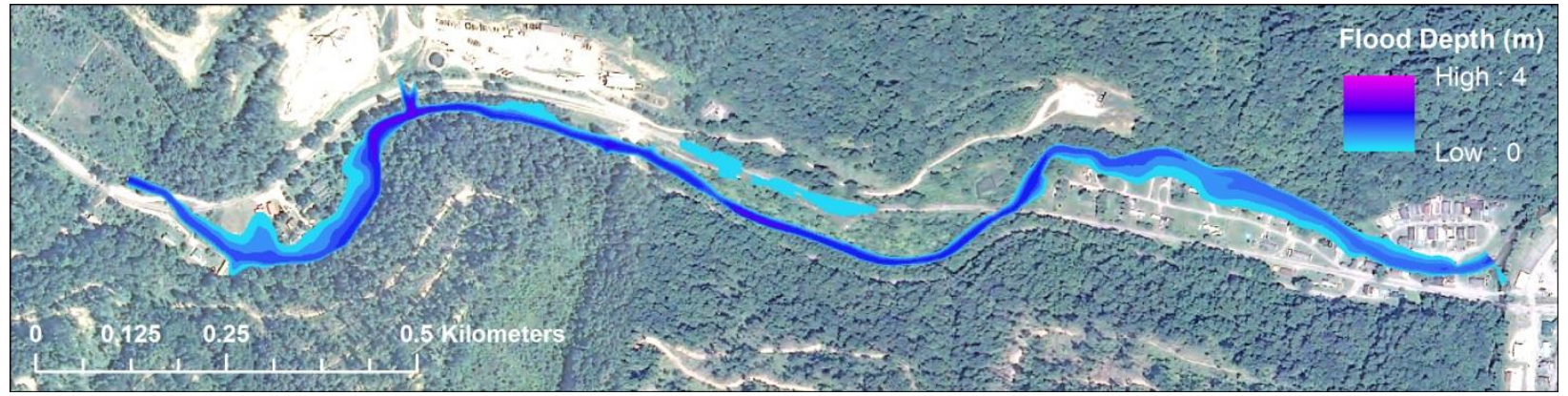

Figure 13: Conventional 500-yr flood extents and depth

\subsubsection{GLD (During mining)}

The GLD (During mining) steady flow analysis results are displayed in Table 5 and Figures 14-16. The maximum channel depth increased for every modeled storm event from the GLD (During mining) reclamation condition when compared to pre-mining depths. The 2-yr, 100-yr, and 500-yr channel depths increased 96\%, 54\%, and 55\%, respectively.

Table 5: GLD (During mining) reclamation condition steady flow analysis results

\begin{tabular}{cccccc}
\hline $\begin{array}{c}\text { Rainfall } \\
\text { Return } \\
\text { Period } \\
(\mathbf{y r})\end{array}$ & $\begin{array}{c}\text { Flood Extents* } \\
(\mathbf{m})\end{array}$ & $\begin{array}{c}\text { Max. } \\
\text { Depth } \\
(\mathbf{m})\end{array}$ & $\begin{array}{c}\text { Cross-Sectional } \\
\text { Flow Area* } \\
\left(\mathbf{m}^{\mathbf{2}}\right)\end{array}$ & $\begin{array}{c}\text { Average } \\
\text { Velocity } \\
(\mathbf{m} / \mathbf{s})\end{array}$ & $\begin{array}{c}\text { Flood } \\
\text { Surface Area } \\
\left(\mathbf{k m}^{\mathbf{2}}\right)\end{array}$ \\
\hline 2 & $19.6(9.7-42.6)$ & 1.7 & $13.5(7.4-46.8)$ & 1.8 & 38.6 \\
100 & $35.6(12.9-85.1)$ & 3.0 & $33.7(17.6-114.1)$ & 2.4 & 66.5 \\
500 & $44.8(15.1-99.3)$ & 3.5 & $47.7(23.3-156.6)$ & 2.6 & 85.6 \\
\hline \multirow{2}{*}{ *mean and range in parentheses }
\end{tabular}


The GLD (During mining) reclamation condition resulted in an increased inundated area for all calculated storm event peak flows. In comparison to the pre-mining conditions, the 2-yr storm event increased 68\%, 100-yr increased 61\%, and 500-yr increased $75 \%$.

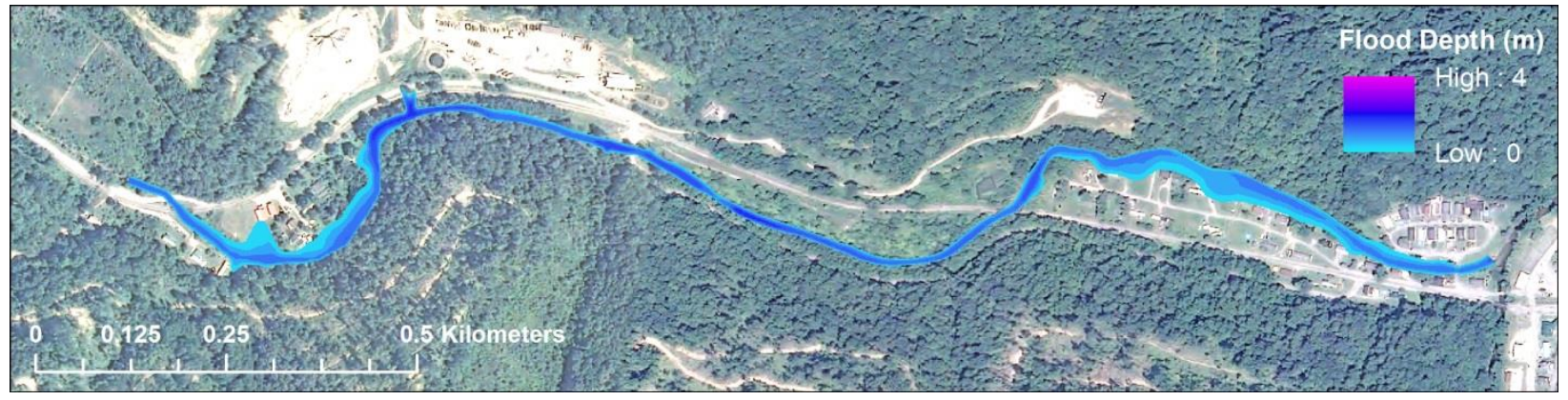

Figure 14: GLD (During mining) 2-yr flood extents and depth

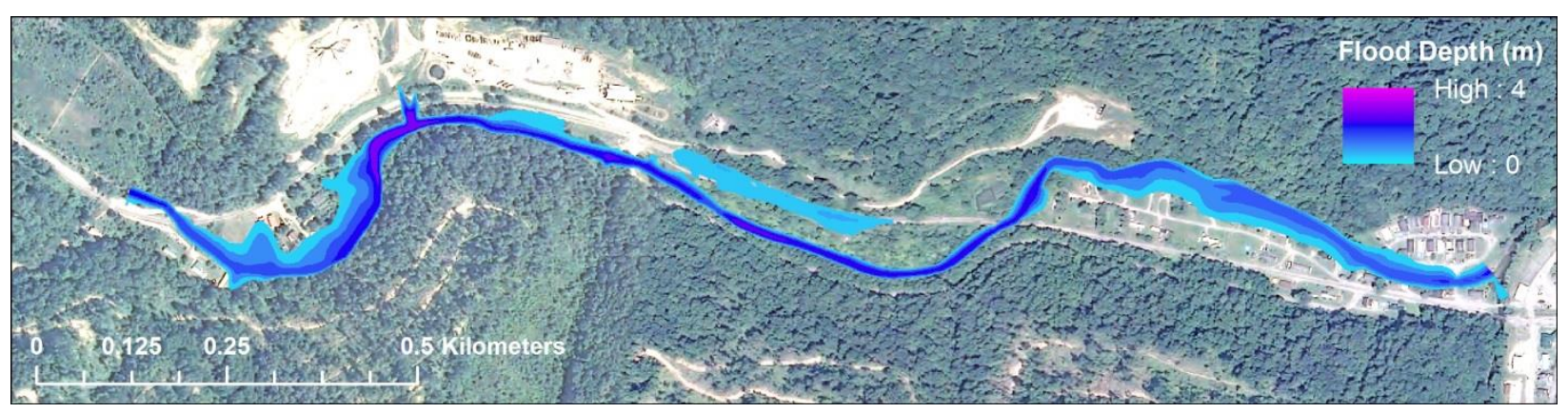

Figure 15: GLD (During mining) 100-yr flood extents and depth

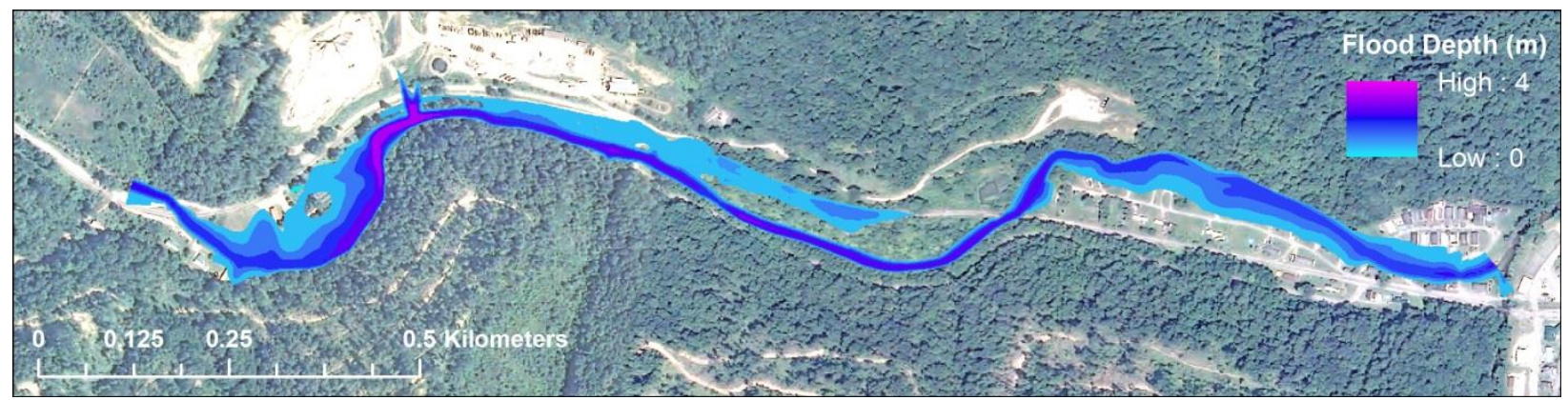

Figure 16: GLD (During mining) 500-yr flood extents and depth 


\subsubsection{GLD (Post-mining)}

Steady flow analysis results of the GLD (Post-mining) reclamation condition are displayed in Table 6 and Figures 17-19. The 2-yr and 100-yr channel depths decreased in comparison to pre-mining channel depths. The 2-yr and 100-yr both decreased by $3 \%$. The 500yr GLD (Post-mining) maximum channel depth increased by $1 \%$ compared to pre-mining.

Table 6: GLD (Post-mining) reclamation condition steady flow analysis results

\begin{tabular}{cccccc}
\hline $\begin{array}{c}\text { Rainfall } \\
\text { Return } \\
\begin{array}{c}\text { Period } \\
(\mathbf{y r})\end{array}\end{array}$ & $\begin{array}{c}\text { Flood Extents* } \\
(\mathbf{m})\end{array}$ & $\begin{array}{c}\text { Max. } \\
\text { Depth } \\
(\mathbf{m})\end{array}$ & $\begin{array}{c}\text { Cross-Sectional } \\
\text { Flow Area* } \\
\left(\mathbf{m}^{\mathbf{2}}\right)\end{array}$ & $\begin{array}{c}\text { Average } \\
\text { Velocity } \\
(\mathbf{m} / \mathbf{s})\end{array}$ & $\begin{array}{c}\text { Flood } \\
\text { Surface Area } \\
\left(\mathbf{k m}^{\mathbf{2}}\right)\end{array}$ \\
\hline 2 & $11.6(6.0-28.7)$ & 0.9 & $4.1(2.1-17.2)$ & 1.1 & 23.0 \\
100 & $20.7(10.0-44.1)$ & 1.9 & $15.0(8.2-51.2)$ & 1.9 & 40.5 \\
500 & $26.0(11.2-56.1)$ & 2.3 & $21.3(11.6-72.2)$ & 2.1 & 49.2 \\
\hline$*$ mean and range in parentheses
\end{tabular}

The inundated areas from the GLD (Post-mining) reclamation condition resulted in small changes in comparison to the pre-mining condition. There was no change in from the 2-yr storm event. The 100-yr storm event resulted in a $2 \%$ decrease in flooded area. The $500-y r$ storm event inundated area increased by $1 \%$ compared to pre-mining conditions.

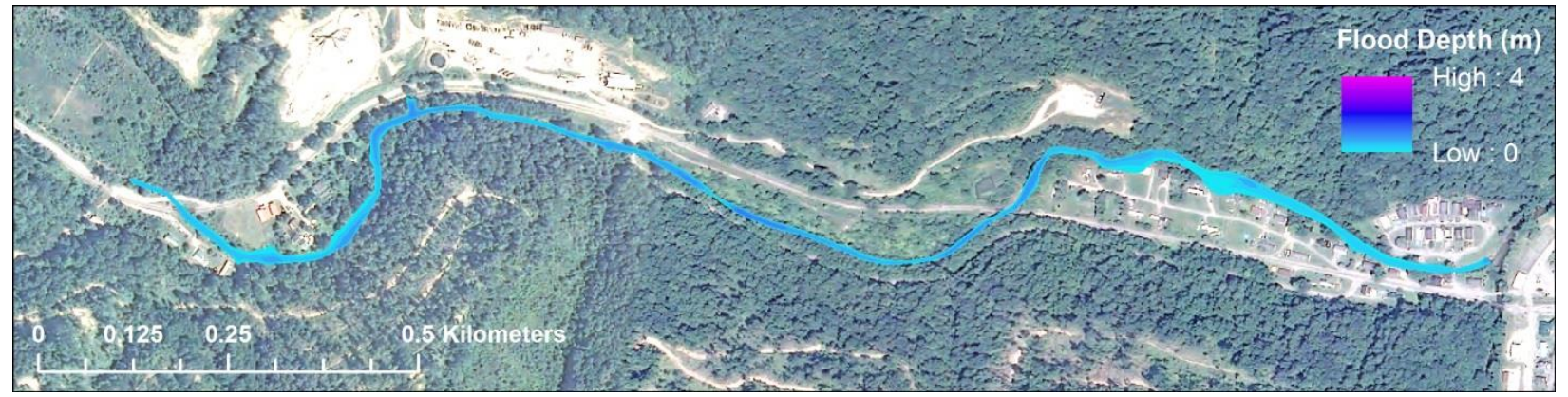

Figure 17: GLD (Post-mining) 2-yr flood extents and depth 


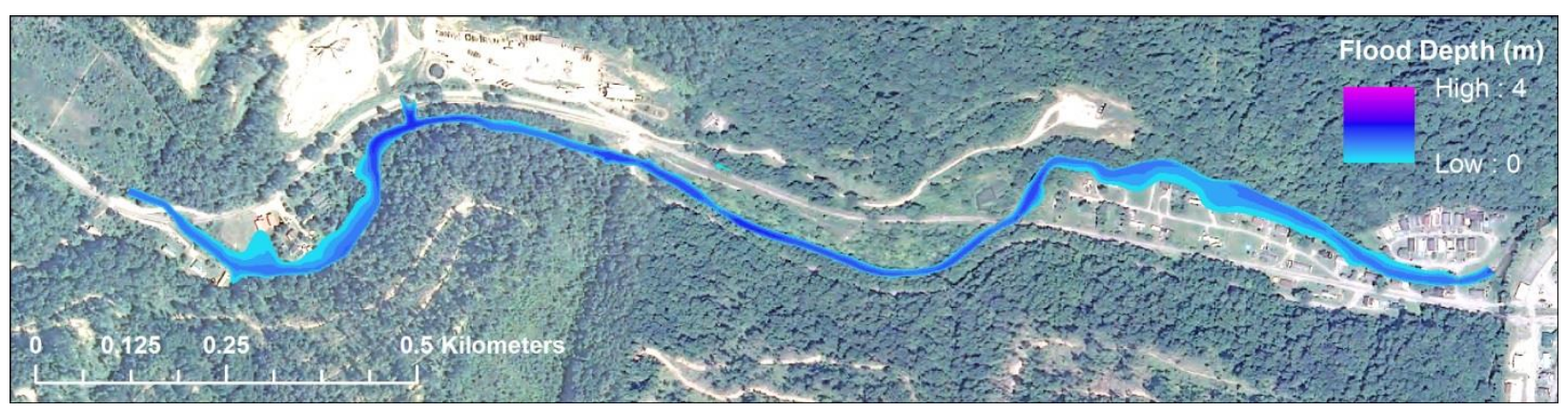

Figure 18: GLD (Post-mining) 100-yr flood extents and depth

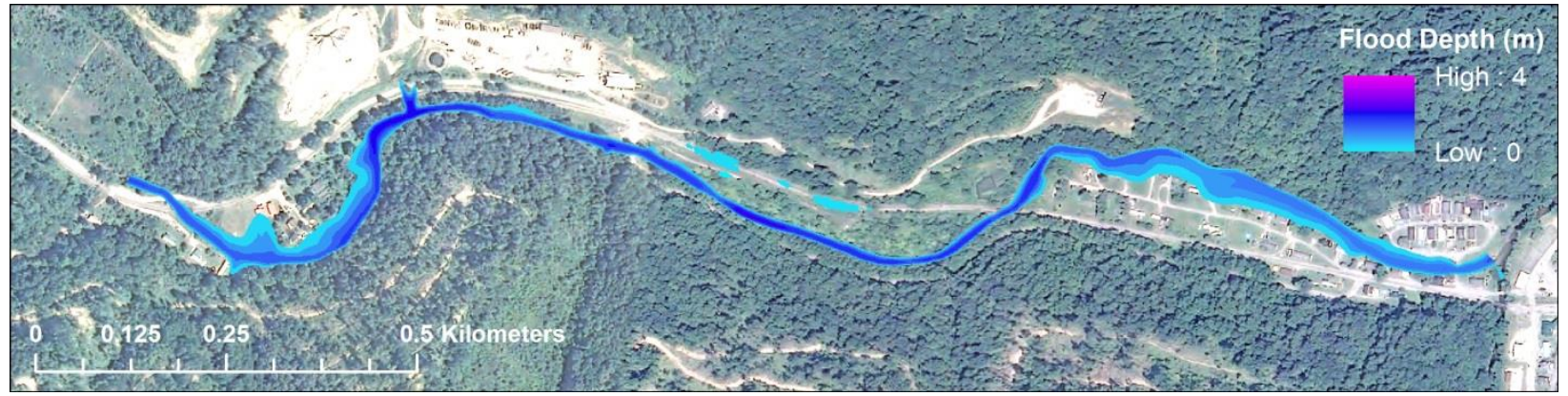

Figure 19: GLD (Post-mining) 500-yr flood extents and depth

\subsubsection{Comparison of Reclamation Designs to Pre-mined Condition}

The greatest flooding extents and depths for each storm event resulted from the GLD (During mining) reclamation condition. Conventional reclamation resulted in the least flooding impacts for the 2-year storm event. GLD (Post-mining) caused the least flooding impacts for the 100-year and 500-year storm events. The results from the GLD (Post-mining) reclamation condition were comparable to pre-mining results, often showing either no change or a decrease in outputs. In instances where the GLD (Post-mining) results were greater than those from the pre-mining condition, the maximum increase was $1 \%$. Table 7 presents the difference in flood area as a percentage for each reclamation condition compared to the pre-mined condition.

The physical environment and ecological community characteristic of a stream are defined by the variations in frequency, magnitude, duration, and regularity of flow (Bednarek 2001, Shafroth et al. 2010). Changes in flooding can cause both socioeconomic and environmental impacts. These include damages to floodplain landscapes, deterioration of water 
quality, disturbances to flora and fauna, and alteration to stream connectivity (Istomina et al. 2005). Organisms found in flood pulsing environments are typically adapted to the fluctuating environmental condition, however in low-order streams where pulses are brief and unpredictable, such as the study reach, the level of adaptation is low (Junk et al. 1989, Birkland et al. 2003).

The decrease in inundation area for the 2-yr conventional reclamation could decrease the impacts on communities and infrastructure, but could potentially result in altered channels and decreased biological activity and diversity. The increases seen from the GLD (During mining) condition would result in increased socioeconomic impacts during flood events such as damage to homes, bridges, roads, and agricultural land. The GLD (During mining) condition may also cause bank erosion, altered biological communities, and affect surrounding vegetation and animals. These effects could potentially be mitigated with the incorporation of detention or channel improvements. The outcomes of the GLD (Post-mining) condition demonstrate that when GLD reclamation reaches a mature state, the flood response could potentially be similar to that of the original topography. This is important because flood frequency is imperative for ecological services.

Table 7: Percent change in inundation area between reclamation conditions and premining

\begin{tabular}{cccc}
$\begin{array}{c}\text { Rainfall Return Period } \\
(\mathbf{y r})\end{array}$ & Conventional & GLD (During Mining) & GLD (Post-Mining) \\
\hline $\mathbf{2}-\mathbf{y r}$ & $-20 \%$ & $68 \%$ & $0 \%$ \\
$\mathbf{1 0 0}-\mathbf{y r}$ & $14 \%$ & $61 \%$ & $-2 \%$ \\
$\mathbf{5 0 0 - y r}$ & $15 \%$ & $75 \%$ & $1 \%$ \\
\hline
\end{tabular}

Percent difference between reclamation conditions and pre-mining conditions were calculated for each section. Tables 8-10 display the average percent difference of cross-sectional outputs for each reclamation technique for the 2-yr, 100-yr, and 500-yr storm events.

The averaged percent change of cross-sectional outputs (i.e. maximum channel depth, cross-sectional flow area, average velocity, and top width) of each reclamation compared to the pre-mining as a result of a 2-yr storm event are shown in Table 8. The conventional reclamation resulted in reduced cross-sectional outputs compared to the pre-mining condition for a 2 -yr storm 
event. The average cross-sectional outputs increased significantly for the GLD (During mining) condition from a 2-yr storm event. The 2-yr GLD (Post-mining) reclamation had very little change in channel velocity, flow area, top width, and maximum channel depth compared to the pre-mining condition.

Table 8: Average percent difference between original topography and reclamation designs over all cross-sectional outputs for 2 -yr

\begin{tabular}{cccc}
\hline & Conventional & $\begin{array}{c}\text { GLD (During } \\
\text { Mining) }\end{array}$ & GLD (Post-Mining) \\
\hline $\begin{array}{c}\text { Average Channel } \\
\text { Velocity Difference }\end{array}$ & $-21 \%$ & $63 \%$ & $0 \%$ \\
$\begin{array}{c}\text { Average Flow Area } \\
\text { Difference }\end{array}$ & $-44 \%$ & $238 \%$ & $1 \%$ \\
$\begin{array}{c}\text { Average Top Width } \\
\text { Difference }\end{array}$ & $-19 \%$ & $66 \%$ & $0 \%$ \\
$\begin{array}{c}\text { Average Max. Channel } \\
\text { Depth Difference }\end{array}$ & $-30 \%$ & $112 \%$ & $0 \%$ \\
\hline
\end{tabular}

The three reclamation conditions are compared to the pre-mining condition for the $100-\mathrm{yr}$ storm event by average percent change of cross-sectional outputs (Table 9). Both the conventional and GLD (During mining) reclamation conditions saw an increase in the average cross-sectional outputs, with GLD (During mining) resulting in the greatest increases. When compared to the pre-mining condition, the modeled GLD (Post-mining) results decreased overall with a reduced average channel velocity, flow area, top width, and channel depth. 
Table 9: Average percent difference between original topography and reclamation designs over all cross-sectional outputs for 100-yr

\begin{tabular}{cccc}
\hline & Conventional & $\begin{array}{c}\text { GLD (During } \\
\text { Mining) }\end{array}$ & GLD (Post-Mining) \\
\hline $\begin{array}{c}\text { Average Channel } \\
\text { Velocity Difference } \\
\text { Average Flow Area } \\
\quad \text { Difference }\end{array}$ & $9 \%$ & $29 \%$ & $-2 \%$ \\
$\begin{array}{c}\text { Average Top Width } \\
\text { Difference }\end{array}$ & $27 \%$ & $118 \%$ & $-5 \%$ \\
$\begin{array}{c}\text { Average Max. Channel } \\
\text { Depth Difference }\end{array}$ & $16 \%$ & $76 \%$ & $-3 \%$ \\
\hline
\end{tabular}

The 500-yr comparison of average cross-sectional outputs of reclamation conditions to the pre-mining condition are displayed in Table 10. The 500-yr storm event resulted in an increase in average cross-sectional properties for the conventional and GLD (During mining) conditions when compared to pre-mining. The GLD (Post-mining) conditions saw no change in average channel velocity and only a $1 \%$ increase in average flow area, top width, and maximum channel depth compared to pre-mining conditions. 
Table 10: Average percent difference between original topography and reclamation designs over all cross-sectional outputs for 500-yr

\begin{tabular}{cccc}
\hline & Conventional & $\begin{array}{c}\text { GLD (During } \\
\text { Mining) }\end{array}$ & GLD (Post-Mining) \\
\hline $\begin{array}{c}\text { Average Channel } \\
\text { Velocity Difference }\end{array}$ & $7 \%$ & $25 \%$ & $0 \%$ \\
$\begin{array}{c}\text { Average Flow Area } \\
\text { Difference }\end{array}$ & $23 \%$ & $129 \%$ & $1 \%$ \\
$\begin{array}{c}\text { Average Top Width } \\
\text { Difference }\end{array}$ & $17 \%$ & $85 \%$ & $1 \%$ \\
$\begin{array}{c}\text { Average Max. Channel } \\
\text { Depth Difference }\end{array}$ & $12 \%$ & $51 \%$ & $1 \%$ \\
\hline
\end{tabular}

The greatest increases from the pre-mining conditions occurred from the GLD (During mining) reclamation condition for all modeled storm events. Conventional reclamation resulted in decreased outputs for the smaller storm event, but increased during the two larger storm events. The GLD (Post-mining) reclamation conditions remained comparable to the pre-mining conditions. The greatest increases from the GLD (Post-mining) were only 1\%, occurring during the 2-yr and 500-yr storm events, whereas the 100-yr saw decreases in average cross-sectional outputs.

\subsection{Unsteady Analysis}

The unsteady analysis results of the study reach for a 24-hour period are presented in the following sections. The maximum water surface for each cross-section over the 24-hr period was used for analysis. The times the maximum water surfaces occurred for each cross-section are given in Appendix B (Tables 24-27). The cross-sectional outputs associated with the maximum water surface levels were used to analyze the unsteady model results. Tables (11-14) present these cross-sectional outputs for each reclamation condition. The maximum water surface levels for each cross-section over a 24-hour period were used to display inundation areas and flood depths to represent the maximum affected areas. Maps illustrating this information for 
pre-mining and three reclamation conditions are shown in Figures 20-35. The findings for each reclamation condition are then compared to the pre-mining condition.

\subsubsection{Pre-mining}

The pre-mining cross-sectional outputs are presented in Table 11 and modeled inundation areas and flood depths are shown in Figures 20-23.

Table 11: Maximum water surface pre-mining condition unsteady flow analysis results

\begin{tabular}{cccccc}
\hline $\begin{array}{c}\text { Rainfall } \\
\begin{array}{c}\text { Return Period } \\
(\mathbf{y r})\end{array}\end{array}$ & $\begin{array}{c}\text { Flood } \\
\text { Extents* } \\
(\mathbf{m})\end{array}$ & $\begin{array}{c}\text { Max. Depth } \\
(\mathbf{m})\end{array}$ & $\begin{array}{c}\text { Croctional Flow } \\
\text { Area* } \\
\left(\mathbf{m}^{\mathbf{2}}\right)\end{array}$ & $\begin{array}{c}\text { Average } \\
\text { Velocity } \\
(\mathbf{m} / \mathbf{s})\end{array}$ & $\begin{array}{c}\text { Flood Surface } \\
\text { Area } \\
\left.\mathbf{( k m}^{\mathbf{2}}\right)\end{array}$ \\
\hline 2 & $11.6(5.7-27.1)$ & 1.0 & $4.1(1.4-16.5)$ & 1.0 & 22.9 \\
50 & $18.9(8.2-41.0)$ & 1.9 & $12.4(4.8-42.7)$ & 1.6 & 37.1 \\
100 & $20.4(8.7-44.6)$ & 2.1 & $14.5(5.7-48.4)$ & 1.8 & 39.7 \\
500 & $24.1(9.7-54.9)$ & 2.5 & $19.2(7.4-61.5)$ & 2.0 & 45.9 \\
\hline
\end{tabular}

*mean and range in parentheses

The flood depths and inundated areas for the maximum water surface level per crosssection for the 2-yr, 50-yr, 100-yr, and 500-yr storm events are presented in Figures 20, 21, 22, and 23. Pre-mining results are used in the following sections to compare the conventional, GLD (Pre-mining) and GLD (Post-mining) reclamation conditions.

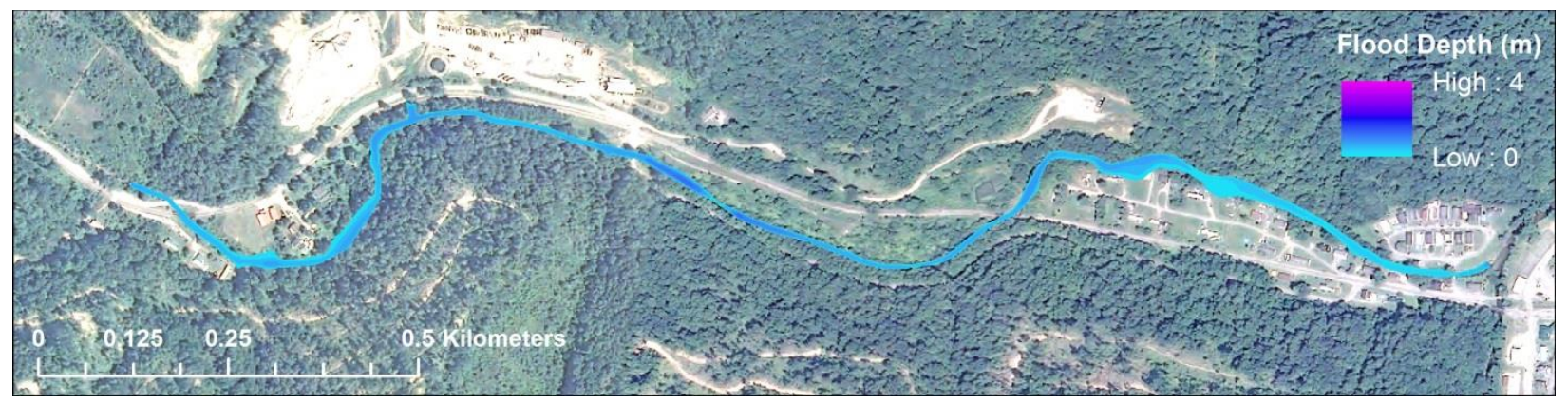

Figure 20: Pre-Mining 2-yr unsteady max water level flood extents and depth 


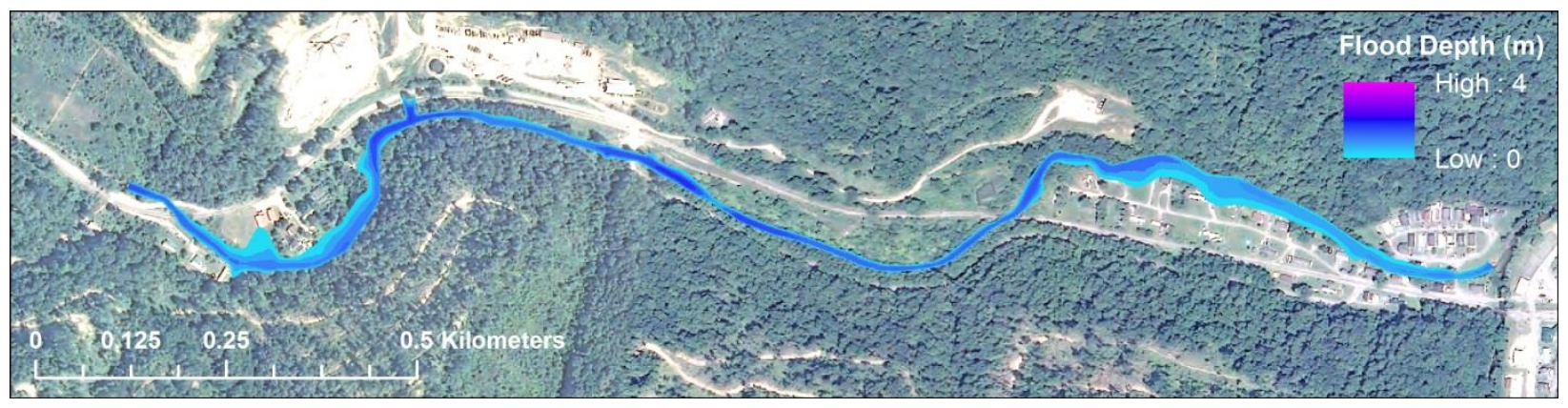

Figure 21: Pre-Mining 50-yr unsteady maximum water level flood extents and depth

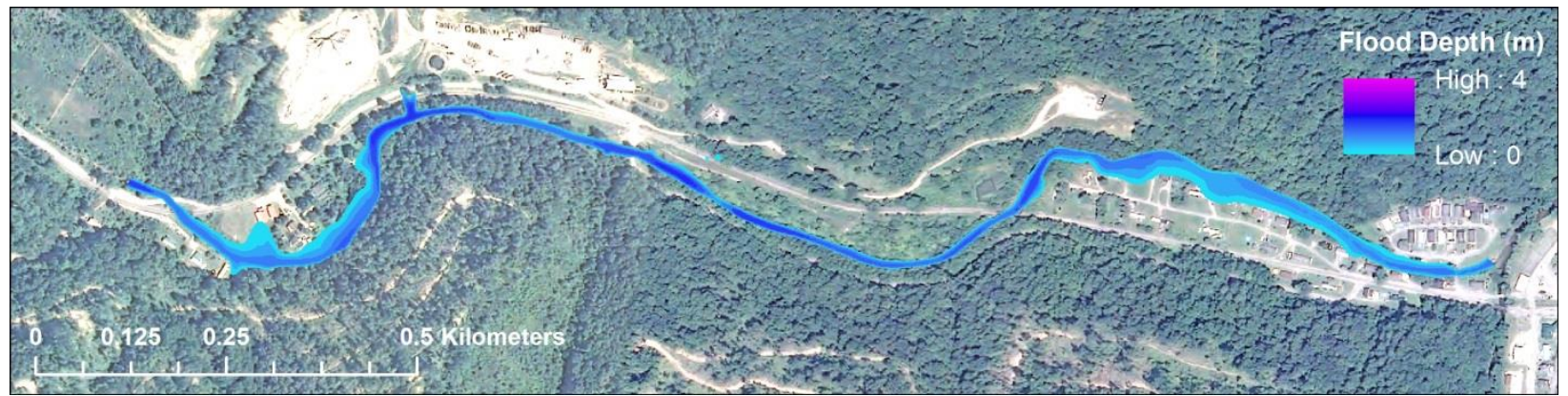

Figure 22: Pre-Mining 100-yr unsteady maximum water level flood extents and depth

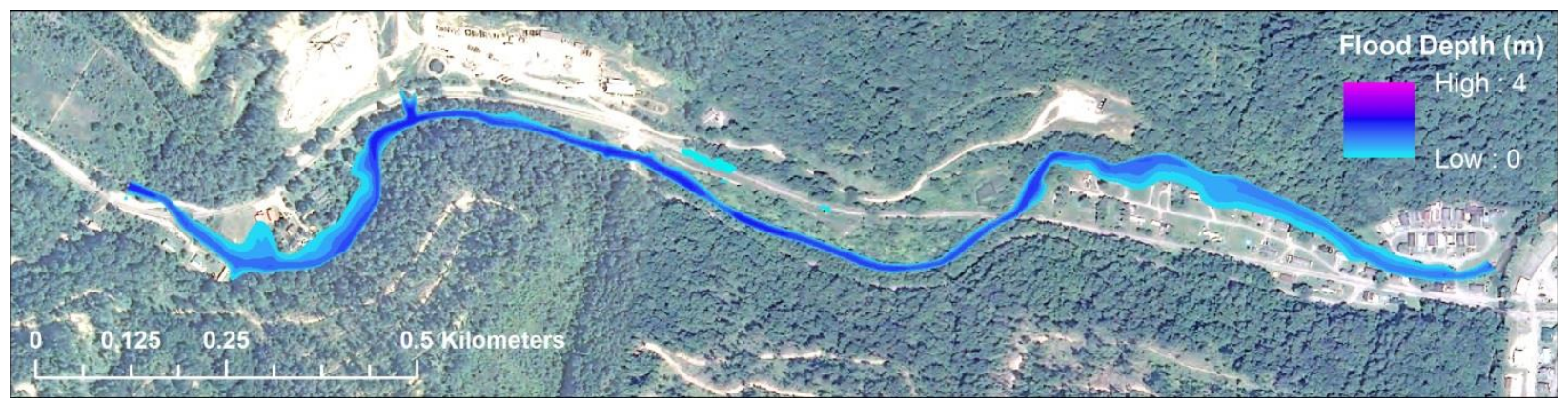

Figure 23: Pre-Mining 500-yr unsteady maximum water level flood extents and depth

\subsubsection{Conventional}

Unsteady analysis results for the conventional reclamation condition are displayed in Table 12 and Figures 24-27. Modeled channel depths corresponding to the maximum water levels from conventional reclamation varied in comparison to pre-mining conditions depending on the return period. The 2-yr storm event produced lower channel depths $(-22 \%)$, whereas the 
50-, 100-, and 500-yr maximum channel depths increased by 15\%, 12\%, and $8 \%$ respectively, compared to those of the pre-mining condition.

Table 12: Maximum water surface conventional condition unsteady flow analysis results

\begin{tabular}{cccccc}
\hline $\begin{array}{c}\text { Rainfall } \\
\text { Return Period } \\
(\mathbf{y r})\end{array}$ & $\begin{array}{c}\text { Flood } \\
\text { Extents* } \\
(\mathbf{m})\end{array}$ & $\begin{array}{c}\text { Max. Depth } \\
(\mathbf{m})\end{array}$ & $\begin{array}{c}\text { Cross- } \\
\text { Sectional Flow } \\
\text { Area* }_{\left(\mathbf{m}^{2}\right)}\end{array}$ & $\begin{array}{c}\text { Average } \\
\text { Velocity } \\
(\mathbf{m} / \mathbf{s})\end{array}$ & $\begin{array}{c}\text { Flood Surface } \\
\text { Area } \\
\left.\mathbf{k m}^{\mathbf{2}}\right)\end{array}$ \\
\hline 2 & $9.4(4.7-24.6)$ & 0.78 & $2.5(0.7-11.2)$ & 0.9 & 18.4 \\
50 & $18.5(8.0-42.1)$ & 2.2 & $12.0(4.5-41.7)$ & 1.6 & 36.5 \\
100 & $20.9(8.7-48.4)$ & 2.3 & $15.0(5.6-50.9)$ & 1.8 & 41.0 \\
500 & $25.0(9.7-61.9)$ & 2.7 & $20.1(7.5-65.5)$ & 2.0 & 49.4 \\
\hline
\end{tabular}

*mean and range in parentheses

The conventional reclamation condition inundated areas for the 2-yr, 50-yr, 100-yr, and 500-year were $18.4,36.5,410$, and $49.4 \mathrm{~km}^{2}$, respectively. In comparison to the pre-mining condition, the 2-yr and 50-yr storm events both resulted in decreased areas of $20 \%$ and $2 \%$. The larger storms resulted in increased flood surface areas with the 100-yr storm increasing by $3 \%$ and the 500-yr storm resulting in an $8 \%$ increase (Figures 24-27).

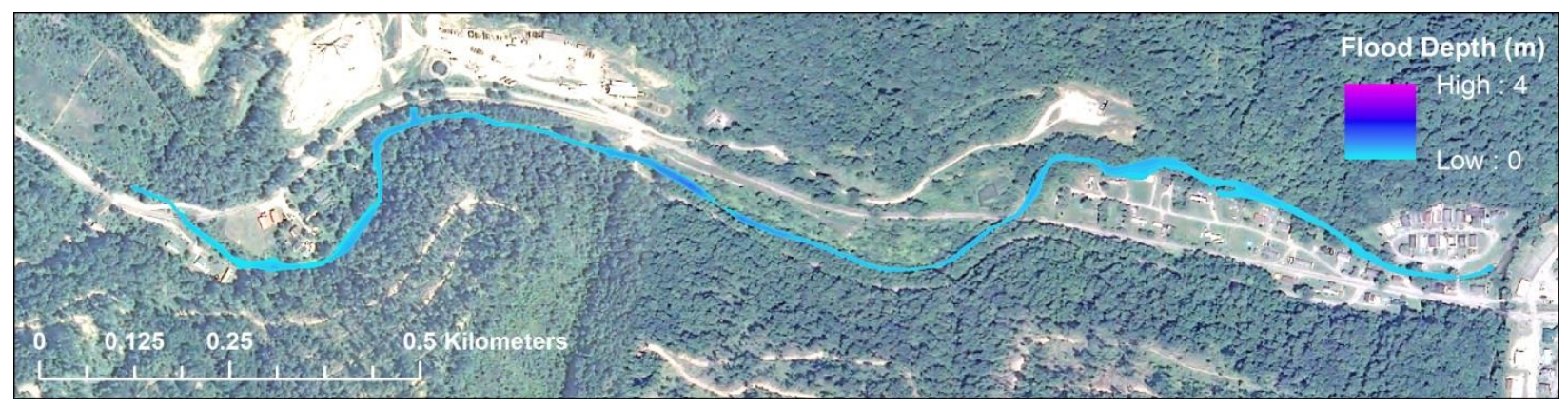

Figure 24: Conventional 2-yr maximum unsteady flood extents and depth 


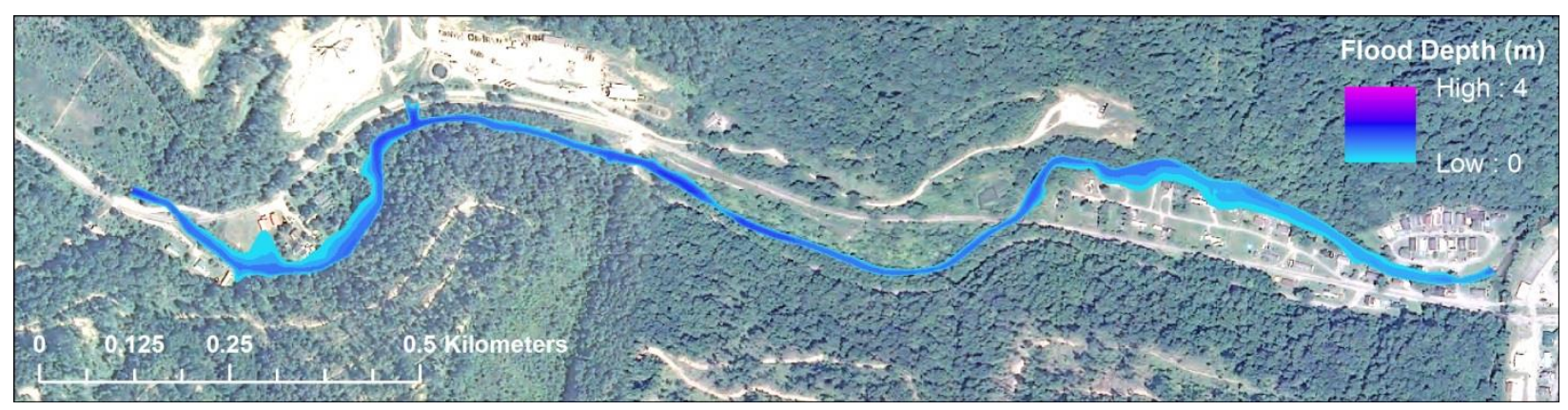

Figure 25: Conventional 50-yr maximum unsteady flood extents and depth

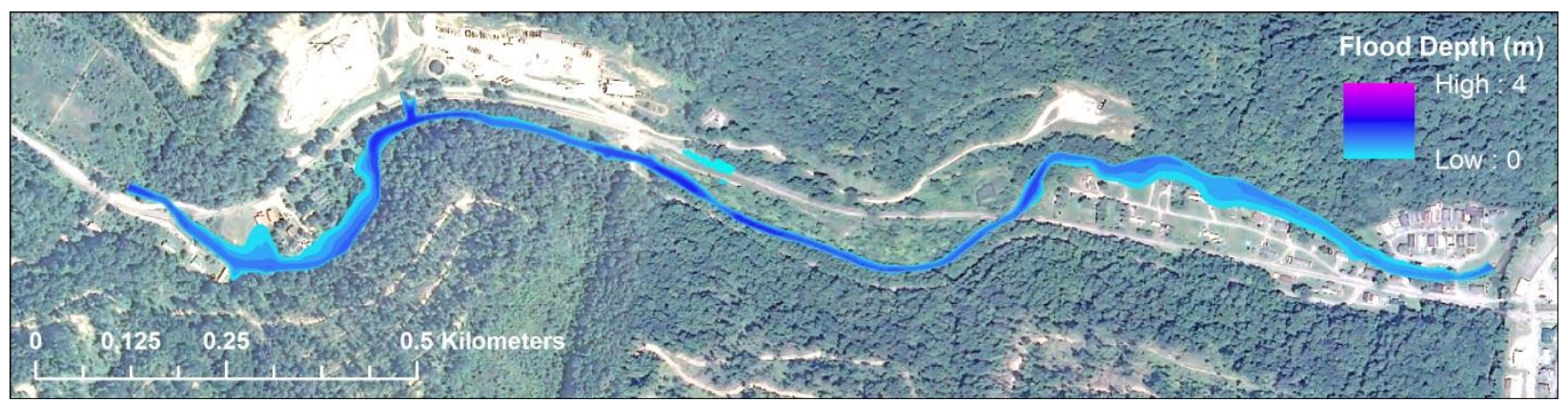

Figure 26: Conventional 100-yr maximum unsteady flood extents and depth

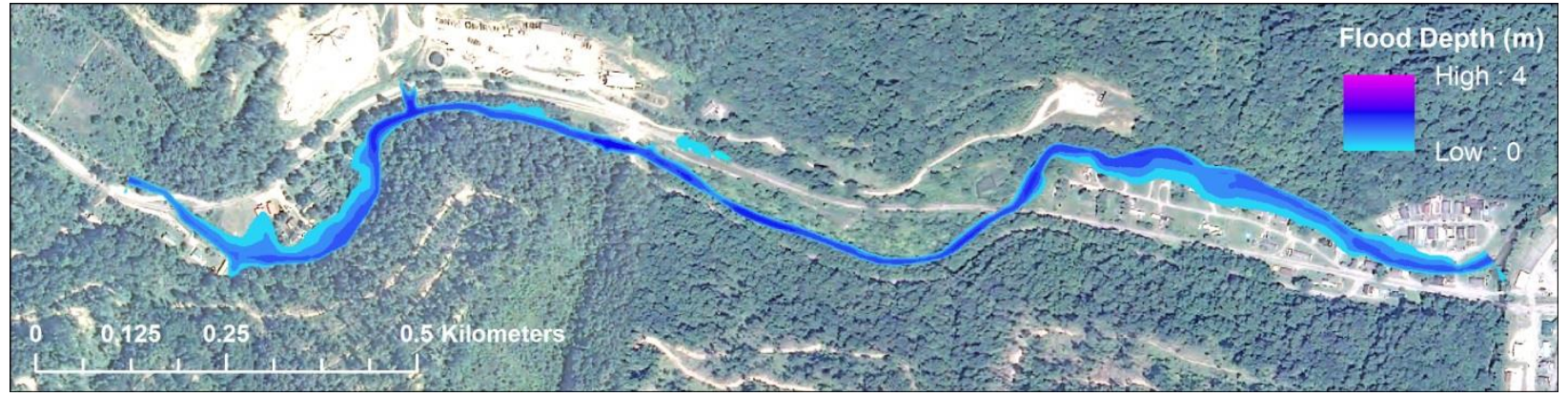

Figure 27: Conventional 500-yr maximum unsteady flood extents and depth

\subsubsection{GLD (During mining)}

Unsteady flow analysis results of the GLD (During mining) condition are shown in Table 13 and Figures 28-31. All modeled storm events resulted in increased maximum channel depths in comparison to the pre-mining condition results. The 2-, 50-, 100-, and 500-yr channel depths increased $102 \%, 72 \%, 66 \%$, and $61 \%$, respectively. 
Table 13: Maximum water surface GLD (During mining) condition unsteady flow analysis results

\begin{tabular}{cccccc}
\hline $\begin{array}{c}\text { Rainfall } \\
\text { Return Period } \\
(\mathbf{y r})\end{array}$ & $\begin{array}{c}\text { Flood } \\
\text { Extents* } \\
(\mathbf{m})\end{array}$ & $\begin{array}{c}\text { Max. Depth } \\
(\mathbf{m})\end{array}$ & $\begin{array}{c}\text { Cross- } \\
\text { Sectional Flow } \\
\text { Area* } \\
\left(\mathbf{m}^{2}\right)\end{array}$ & $\begin{array}{c}\text { Average } \\
\text { Velocity } \\
(\mathbf{m} / \mathbf{s})\end{array}$ & $\begin{array}{c}\text { Flood Surface } \\
\text { Area } \\
\left(\mathbf{k m}^{\mathbf{2}}\right)\end{array}$ \\
\hline 2 & $18.9(8.2-42.3)$ & 2.0 & $12.5(4.8-42.3)$ & 1.6 & 37.1 \\
50 & $\begin{array}{c}30.3(10.6- \\
80.3)\end{array}$ & 3.2 & $26.7(9.3-85.7)$ & 2.2 & 55.7 \\
100 & $\begin{array}{c}33.2(10.9- \\
86.4)\end{array}$ & 3.5 & $\begin{array}{c}30.1(10.0- \\
96.3)\end{array}$ & 2.3 & 60.1 \\
500 & $\begin{array}{c}37.9(11.4- \\
97.6)\end{array}$ & 4.0 & $\begin{array}{c}38.5(11.3- \\
119.0)\end{array}$ & 2.5 & 70.8 \\
\hline
\end{tabular}

*mean and range in parentheses

The inundation areas from the unsteady analysis of the GLD (During mining) condition increased for every modeled storm event. The 2-yr storm event increased 62\%, 50-yr increased $50 \%, 100-y r$ increased $51 \%$, and 500-yr increased 54\%.

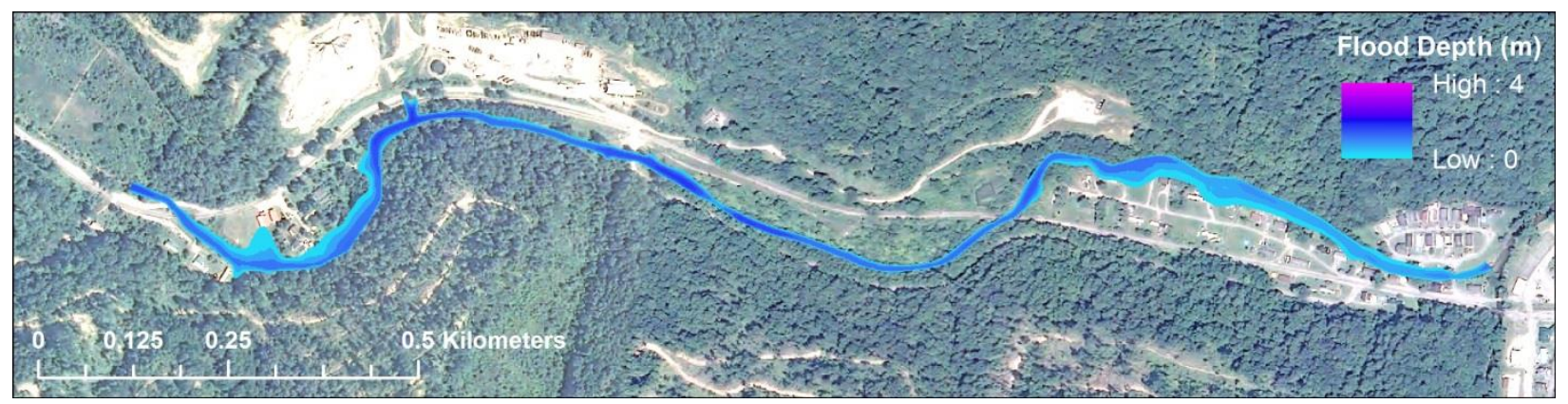

Figure 28: GLD (During mining) 2-yr maximum unsteady flood extents and depth

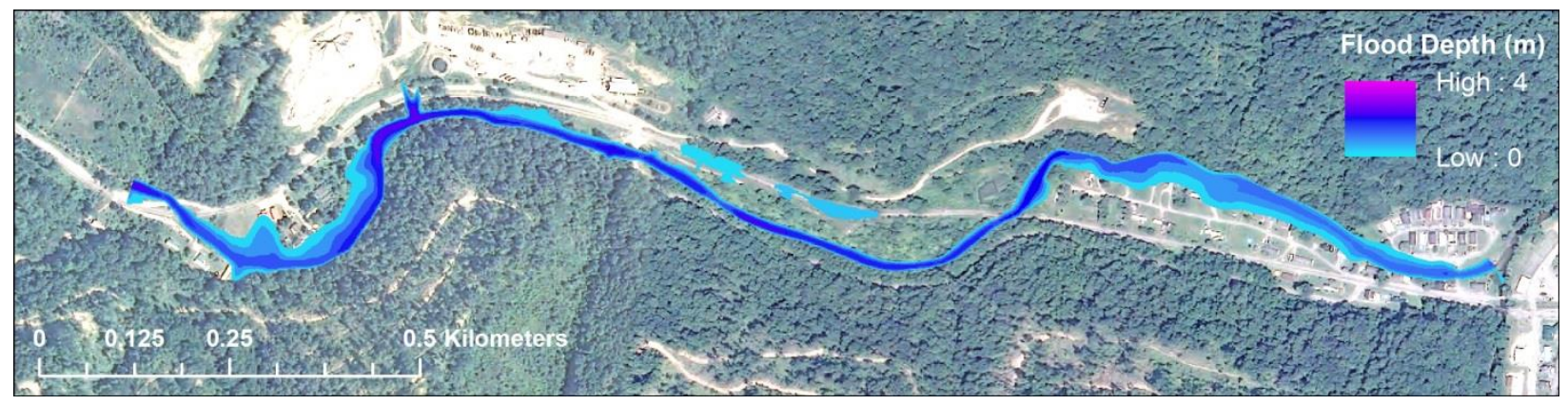

Figure 29: GLD (During mining) 50-yr maximum unsteady flood extents and depth 


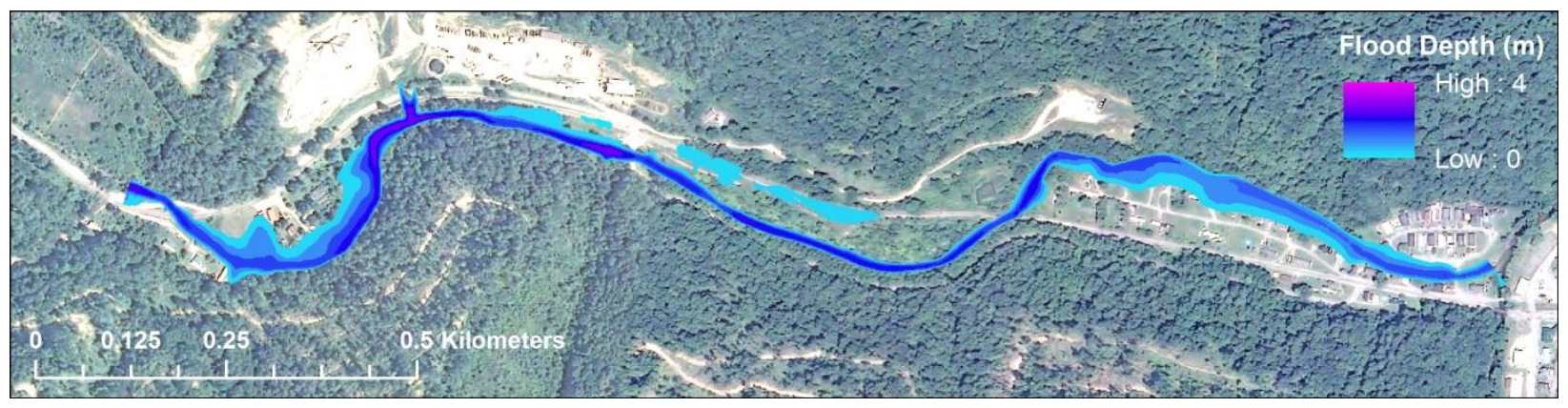

Figure 30: GLD (During mining) 100-yr maximum unsteady flood extents and depth

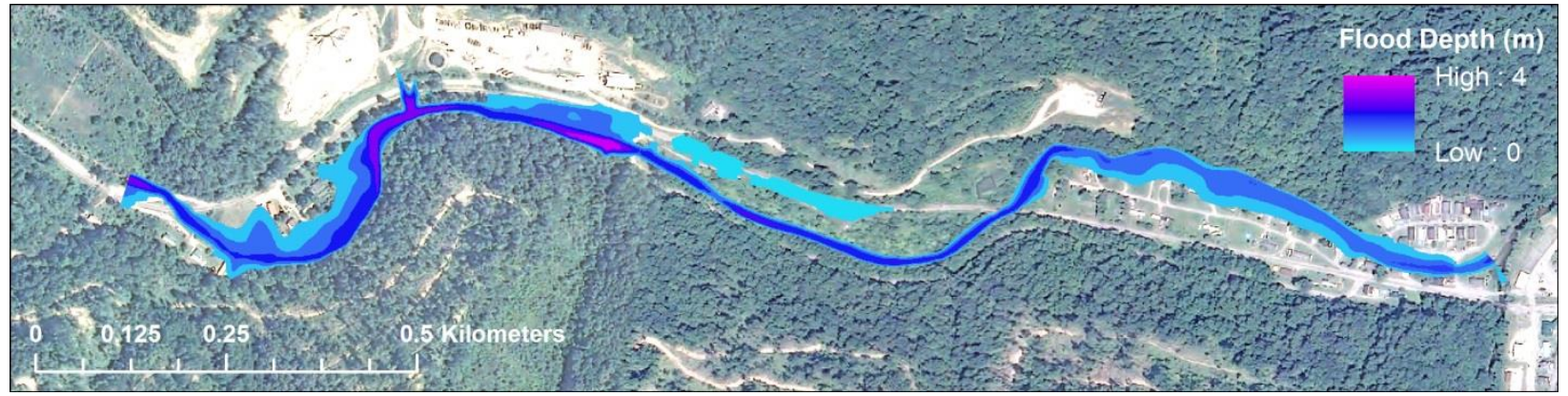

Figure 31: GLD (During mining) 500-yr maximum unsteady flood extents and depth

\subsubsection{GLD (Post-mining)}

The GLD (Post-mining) unsteady analysis results are displayed in Table 14 and Figures 32-35. The maximum channel depths increased for each modeled storm event compared to premining condition channel depths. The channel depths increased for the 2-yr and 500-yr storm events by $2 \%, 50-y r$ by $4 \%$, and $100-y r$ by $3 \%$. 
Table 14: Maximum water surface GLD (Post-mining) condition unsteady flow analysis results

\begin{tabular}{cccccc}
\hline $\begin{array}{c}\text { Rainfall } \\
\text { Return Period } \\
(\mathbf{y r})\end{array}$ & $\begin{array}{c}\text { Flood } \\
\text { Extents* } \\
(\mathbf{m})\end{array}$ & $\begin{array}{c}\text { Max. Depth } \\
(\mathbf{m})\end{array}$ & $\begin{array}{c}\text { Cross- } \\
\text { Sectional Flow } \\
\text { Area* } \\
\left(\mathbf{m}^{2}\right)\end{array}$ & $\begin{array}{c}\text { Average } \\
\text { Velocity } \\
(\mathbf{m} / \mathbf{s})\end{array}$ & $\begin{array}{c}\text { Flood Surface } \\
\text { Area } \\
\left(\mathbf{k m}^{2}\right)\end{array}$ \\
\hline 2 & $11.9(5.8-27.5)$ & 1.0 & $4.4(1.5-17.1)$ & 1.0 & 23.4 \\
50 & $19.1(8.3-42.0)$ & 1.9 & $12.7(4.9-43.7)$ & 1.7 & 37.5 \\
100 & $20.6(8.8-45.5)$ & 2.2 & $14.8(5.7-49.4)$ & 1.8 & 40.1 \\
500 & $24.6(9.7-56.6)$ & 2.6 & $19.5(7.5-62.9)$ & 2.0 & 46.4 \\
\hline
\end{tabular}

*mean and range in parentheses

The inundation areas of the GLD (Post-mining) reclamation condition also saw slight increases for all each modeled storm event. The 2-yr inundated area increased by $2 \%$ and the 50 yr, 100-yr, and 500-yr inundated areas each increased by $1 \%$ compared to pre-mining inundation.

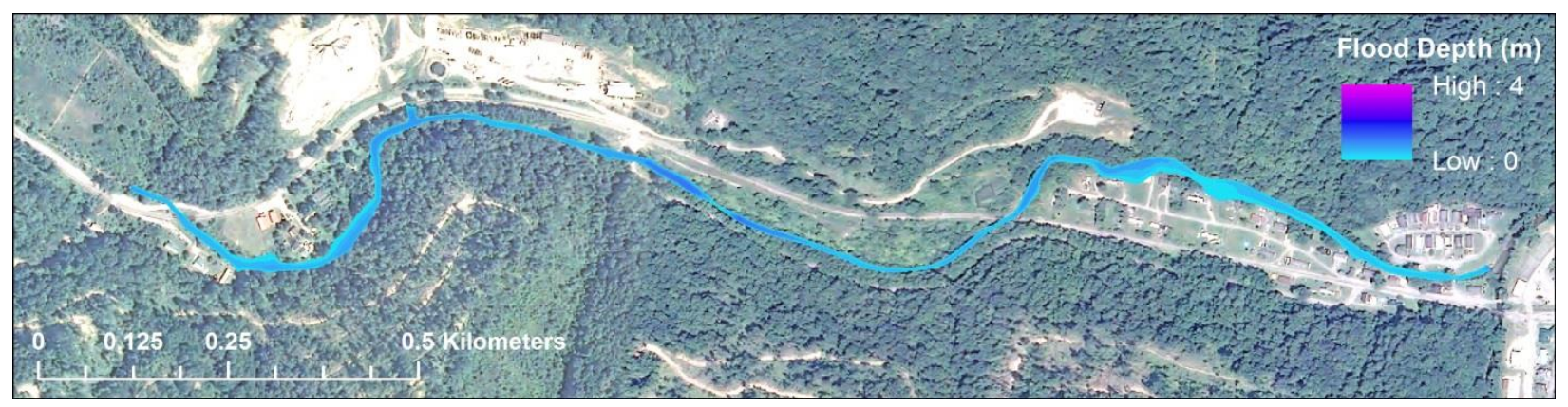

Figure 32: GLD (Post-mining) 2-yr maximum unsteady flood extents and depth

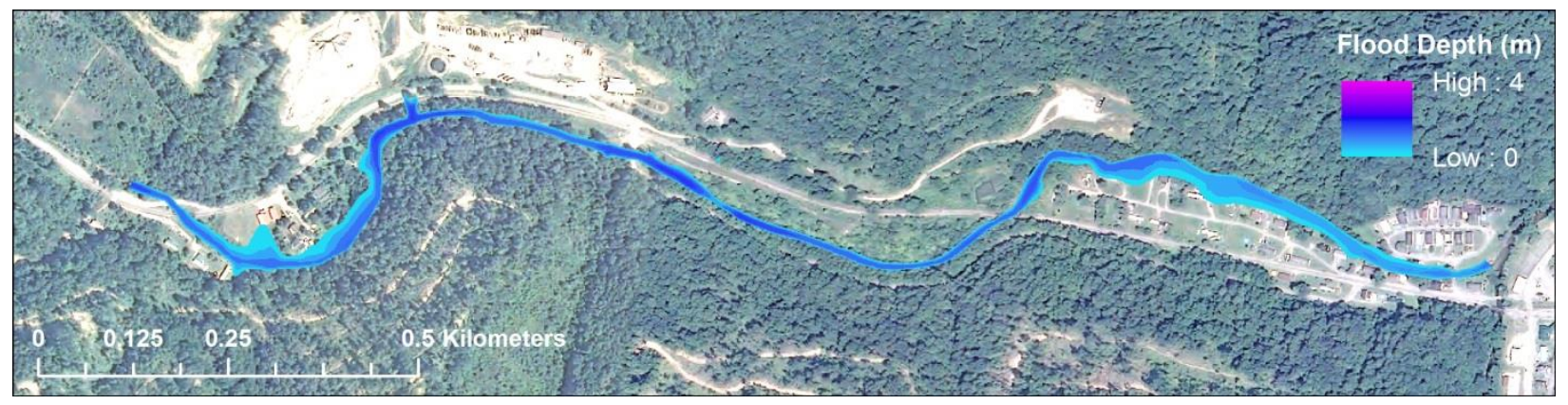

Figure 33: GLD (Post-mining) 50-yr maximum unsteady flood extents and depth 


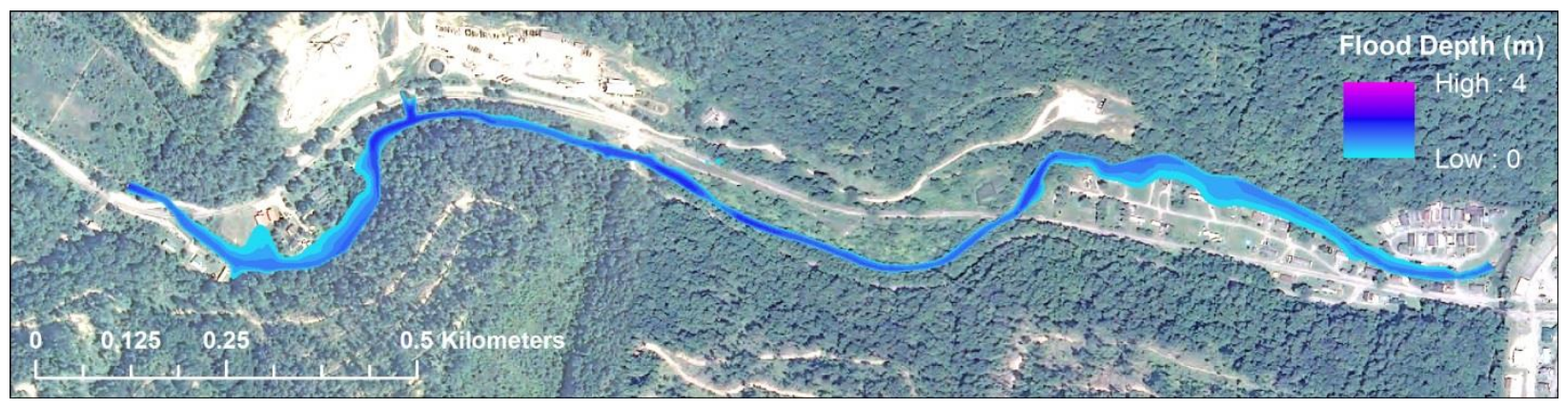

Figure 34: GLD (Post-mining) 100-yr maximum unsteady flood extents and depth

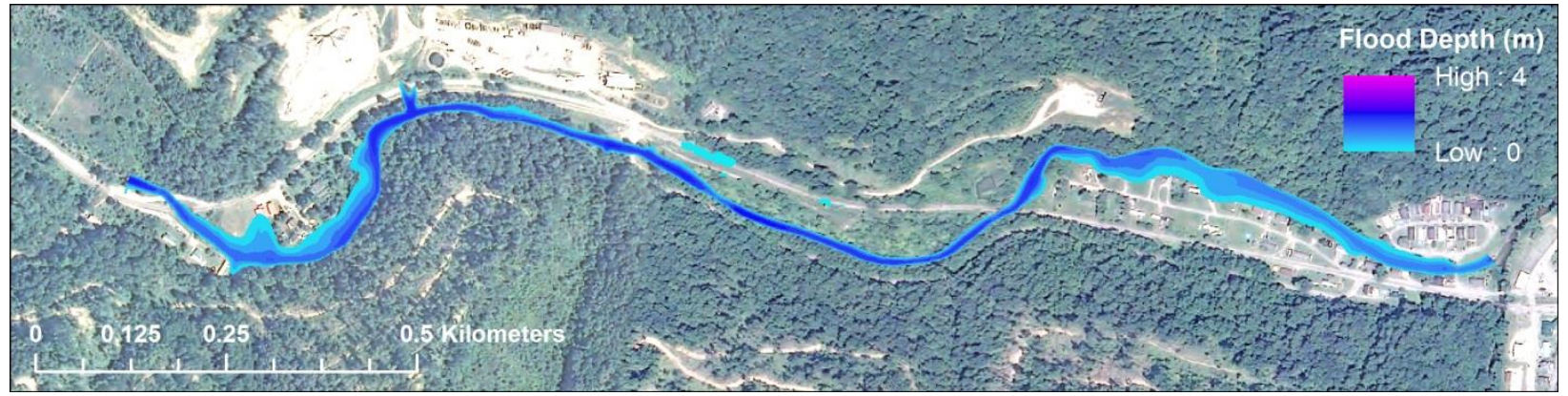

Figure 35: GLD (Post-mining) 500-yr maximum unsteady flood extents and depth

\subsubsection{Comparison of Reclamation Designs to Pre-mined Condition}

The results of each reclamation condition were analyzed based on how they compared to the pre-mined condition for the modeled storm events. The percent change from the pre-mined inundation area to each reclamation condition inundation areas are presented in Table 15.

Table 15: Percent change in inundation area from maximum water elevations between reclamation conditions and pre-mining

\begin{tabular}{cccc}
$\begin{array}{c}\text { Rainfall Return Period } \\
(\mathbf{y r})\end{array}$ & Conventional & GLD (During mining) & GLD (Post-mining) \\
\hline $2-\mathrm{yr}$ & $-20 \%$ & $62 \%$ & $2 \%$ \\
$50-\mathrm{yr}$ & -2 & $50 \%$ & $1 \%$ \\
$100-\mathrm{yr}$ & $3 \%$ & $51 \%$ & $1 \%$ \\
$500-\mathrm{yr}$ & $8 \%$ & $54 \%$ & $1 \%$ \\
\hline
\end{tabular}


The three reclamation conditions were compared by calculating the percent change in the modeled outputs from the pre-mining condition to each reclamation condition. The average percent difference of cross-sectional outputs for each reclamation condition during 2-yr, 50-yr, 100-yr, and 500-yr storm events are displayed in Tables 16-19. Water surface longitudinal profiles of the maximum water surface elevations of each condition for each storm event are also provided in Figures 36-39.

Table 16 presents the 2-yr comparison of each reclamation condition to the pre-mining condition. Figure 36 illustrates the water surface longitudinal profile of the 2-yr storm event for each condition. The conventional reclamation resulted in overall decreases in cross-sectional outputs compared to the pre-mined condition. Both GLD conditions resulted in increases compared to the pre-mined condition, although GLD (During mining) had more significant increases than GLD (Post-mining).

The 2-yr and 50-yr inundation area of the conventional reclamation decreased compared to the pre-mined condition, which could cause potential decreases in flood damage to infrastructure and communities. It may also cause channel alteration and lead to biological activity and diversity decreases (Junk et al. 1989, Birkland et al. 2003). The increased inundation area from GLD (During mining) would increase flood damage to the surrounding area, and may alter biological activity, cause bank erosion, and impact flora and fauna (Bednarek 2001, Istomina et al. 2005). Stormwater BMPs (e.g. flow control structures, retention systems) could potentially be incorporated to mitigate these effects. GLD (Post-mining) results demonstrate how the mature state of GLD reclamation could potentially produce a similar flood response as that of the pre-mined condition. 


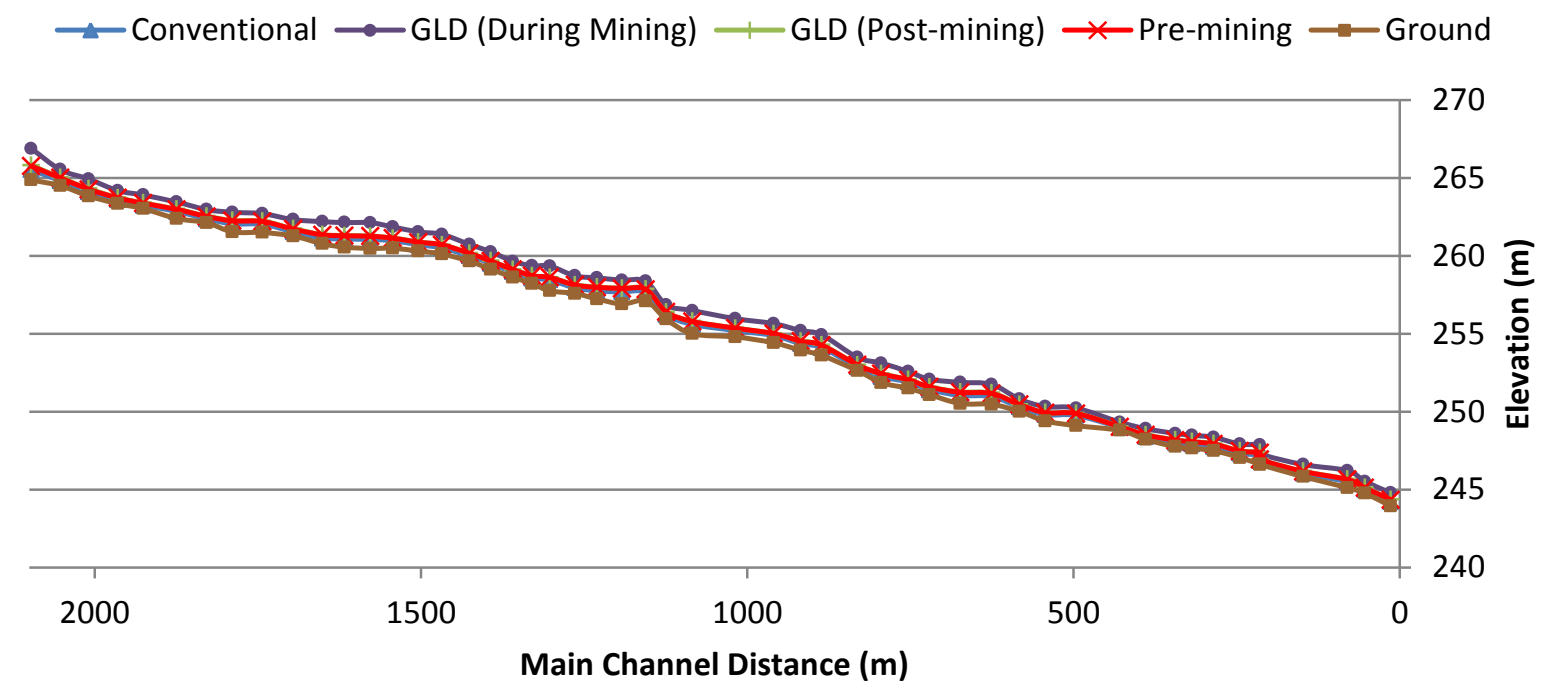

Figure 36: 2-yr water surface longitudinal profile comparison

Table 16: Average percent difference between original topography and reclamation designs over all cross-sectional outputs for 2 -yr

\begin{tabular}{cccc}
\hline & Conventional & $\begin{array}{c}\text { GLD (During } \\
\text { Mining) }\end{array}$ & GLD (Post-Mining) \\
\hline $\begin{array}{c}\text { Average Channel } \\
\text { Velocity Difference }\end{array}$ & $-15 \%$ & $68 \%$ & $1 \%$ \\
$\begin{array}{c}\text { Average Flow Area } \\
\text { Difference }\end{array}$ & $-43 \%$ & $223 \%$ & $6 \%$ \\
$\begin{array}{c}\text { Average Top Width } \\
\text { Difference }\end{array}$ & $-19 \%$ & $62 \%$ & $2 \%$ \\
$\begin{array}{c}\text { Average Max. Channel } \\
\text { Depth Difference }\end{array}$ & $-30 \%$ & $105 \%$ & $3 \%$ \\
\hline
\end{tabular}

The 50-yr water surface longitudinal profiles of the four conditions are represented in Figure 37. Comparison of the average percent difference between the reclamation conditions and pre-mining conditions of the 50-yr cross-sectional outputs are shown in Table 17. The trends found for the 50-yr comparison are similar to those of the 2-yr comparison. The average 
percent changes of the conventional reclamation condition decreased, and both GLD conditions increased. The overall percent changes were smaller compared to the 2-yr outputs.

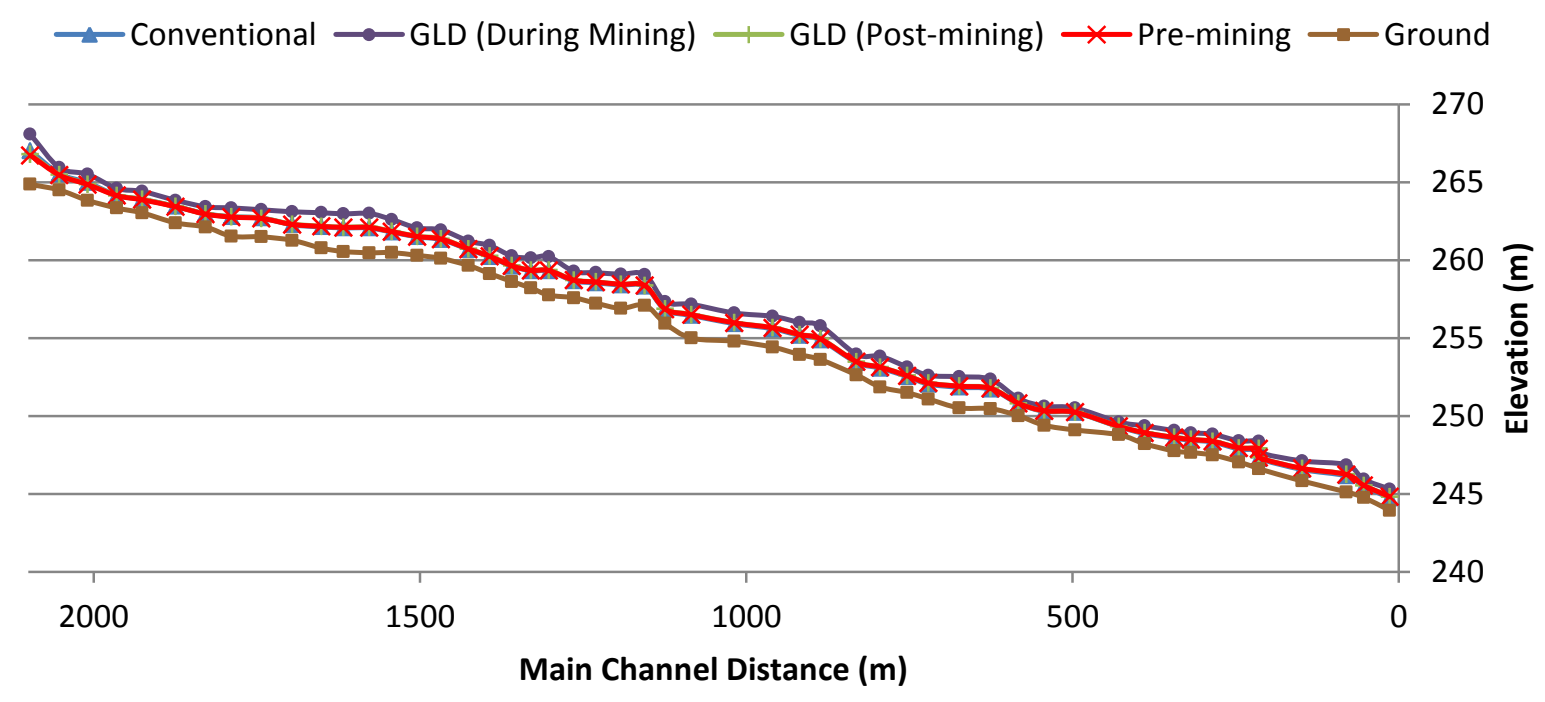

Figure 37: 50-yr water surface longitudinal profile comparison

Table 17: Average percent difference between original topography and reclamation designs over all cross-sectional outputs for 50-yr

\begin{tabular}{cccc}
\hline & Conventional & $\begin{array}{c}\text { GLD (During } \\
\text { Mining) }\end{array}$ & GLD (Post-Mining) \\
\hline $\begin{array}{c}\text { Average Channel } \\
\text { Velocity Difference }\end{array}$ & $-1 \%$ & $36 \%$ & $1 \%$ \\
$\begin{array}{c}\text { Average Flow Area } \\
\text { Difference }\end{array}$ & $-4 \%$ & $114 \%$ & $2 \%$ \\
$\begin{array}{c}\text { Average Top Width } \\
\text { Difference }\end{array}$ & $-2 \%$ & $65 \%$ & $1 \%$ \\
Average Max. Channel \\
Depth Difference
\end{tabular}

The water surface longitudinal profile of each condition during a 100-yr storm event is shown in Figure 38. The comparisons of each reclamation condition to the pre-mining condition 
are shown in Table 18. For the 100-yr storm event, all three reclamation conditions resulted in increases compared to the pre-mining condition. GLD (Post-mining) had the smallest increases, but the conventional reclamation was only $1 \%$ higher than the GLD (Post-mining) in every output category. GLD (During mining) saw the greatest increases compared to pre-mining.

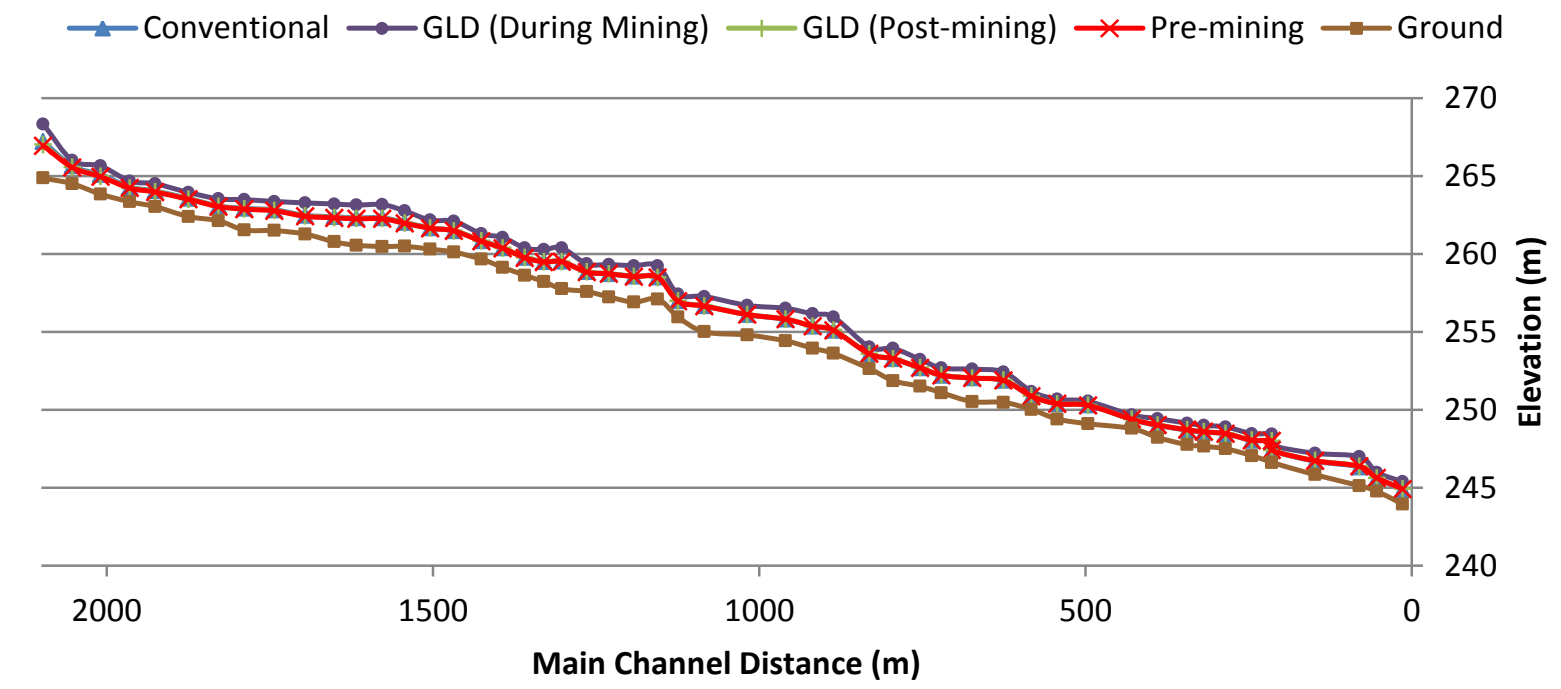

Figure 38: 100-yr water surface longitudinal profile comparison

Table 18: Average percent difference between original topography and reclamation designs over all cross-sectional outputs for 100-yr

\section{Conventional}

GLD (During Mining)
GLD (Post-Mining)
Average Channel

Velocity Difference

Average Flow Area

Difference

Average Top Width

Difference

Average Max. Channel

Depth Difference
$2 \%$

$3 \%$

$105 \%$

$2 \%$

$2 \%$

$69 \%$

$1 \%$

$2 \%$

$31 \%$

$1 \%$ 
The 500-yr storm event water surface longitudinal profiles for each reclamation condition and the pre-mining condition are displayed in Figure 39. Table 19 presents the output of each reclamation condition shown as a percent change from the pre-mined condition for a 500-yr storm event. The trends observed from the 500-yr event are similar to those of the 100-yr. An increase occurred for all three reclamation conditions. The GLD (Post-mining) condition had the smallest increases, with the conventional reclamation condition only slightly higher, and the GLD (During mining) condition with the greatest increases.

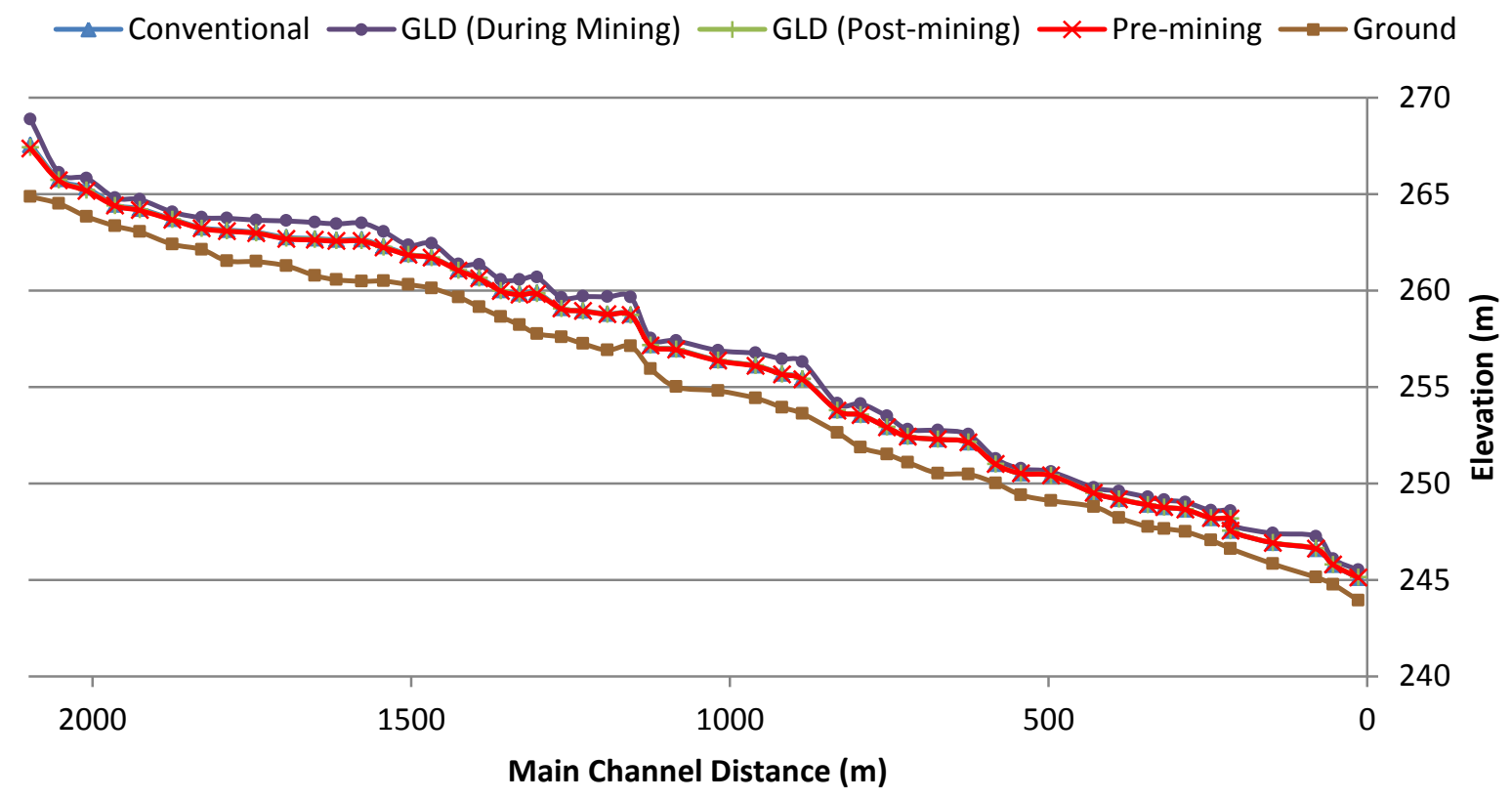

Figure 39: 500-yr water surface longitudinal profile comparison 
Table 19: Average percent difference between original topography and reclamation designs over all cross-sectional outputs for 500 -yr

\begin{tabular}{cccc}
\hline & Conventional & $\begin{array}{c}\text { GLD (During } \\
\text { Mining) }\end{array}$ & GLD (Post-Mining) \\
\hline $\begin{array}{c}\text { Average Channel } \\
\text { Velocity Difference }\end{array}$ & $2 \%$ & $23 \%$ & $1 \%$ \\
$\begin{array}{c}\text { Average Flow Area } \\
\text { Difference }\end{array}$ & $4 \%$ & $96 \%$ & $2 \%$ \\
$\begin{array}{c}\text { Average Top Width } \\
\text { Difference }\end{array}$ & $3 \%$ & $63 \%$ & $1 \%$ \\
$\begin{array}{c}\text { Average Max. Channel } \\
\text { Depth Difference }\end{array}$ & $2 \%$ & $40 \%$ & $1 \%$ \\
\hline
\end{tabular}

\subsection{Comparison of Steady and Unsteady Analysis}

Both steady and unsteady hydraulic analyses were conducted for this research. Both analyses resulted in similar overall trends, and the differences that occurred were minor. The greatest difference between the steady and unsteady analyses were in the GLD (Post-mining) results. The steady GLD (Post-mining) results saw a decrease in outputs in comparison to the pre-mined condition, whereas the unsteady model resulted in no decreases. The unsteady GLD (post-mining) results remained within $1 \%$ change of the pre-mined condition, and could still be considered comparable.

Each analysis had advantages and disadvantages. The only flow data necessary for the steady hydraulic analysis was the peak discharge. Less information was required and therefore was less time consuming and simpler to model. The flood wave is not considered in the steady analysis, and may lead to less accurate results. The unsteady analysis was more complex. A flow hydrograph was required for the flow data input. Due to the increased complexity of the unsteady model, information input was more time consuming and the program required more time to complete. The unsteady analysis modeled the flood wave in time steps and provided a more accurate representation of flooding and associated cross-section outputs over time. 


\section{Conclusions}

The goal of this research was to explore the potential future incorporation of geomorphic landform design techniques into surface mine reclamation in West Virginia. This particular study focused on studying the downstream effects and comparing it to the pre-mining condition and conventional reclamation. Runoff data from a previous study was used to develop a hydraulic model of the $2.1 \mathrm{~km}$ study reach. The water surface elevations from the model were then used to create inundation maps for various storm events for each condition. The results from the reclamation techniques were compared to the pre-mining results. Major research findings include the following:

- For smaller storm events (e.g. 2-yr) conventional reclamation resulted in decreased flooding, but increased flooding was observed for large storm events (100-yr, 500-yr). The decrease in flooding from the smaller storm events could result in negative ecological effects over time. Since the study area is a low-order stream, the flood pulses are brief and unpredictable. Organisms most likely have a low level of adaption (Junk et al. 1989, Birkland et al. 2003). There could potentially be a decrease of biological activity and diversity. The increased flooding resulting from larger storm events may be a concern as the frequency of extreme events increase, as seen in the study from (Kharin and Zwiers 2005).

- The GLD (During mining) reclamation condition had large increases in flooding that are mitigated post-mining. The GLD (Post-mining) results were comparable to those of the pre-mining condition. This is important for both socioeconomic purposes and ecological services.

- The greatest area of concern is the increased flooding during mining. This study did not model the downstream effects of the conventional reclamation during mining, so it cannot be stated how the GLD (During mining) condition compares. The increased flows could be mitigated by incorporating stormwater BMPs. It may also be advantageous to incorporate sediment control structures temporarily during the mining period, which would be removed post-mining.

- GLD has potential to mitigate flooding impacts from surface mining in the long-term. It is dependent on properly sized channels and stability of landforms. 
Application of geomorphic landform design techniques to surface mine reclamation in southern West Virginia could be more beneficial for flood regulation in downstream areas than conventional reclamation. Conventional reclamation decreased flooding during the smaller storm events (e.g. 2-yr, 50-yr) which may be ideal for decreasing flood damages; however, GLD (Post-mining) outperformed conventional reclamation overall by being the most comparable to the pre-mining condition for every modeled storm event, whereas conventional reclamation lacked consistency in its flood response. 


\section{References}

Alho, P., Aaltonen, J. (2008). "Comparing a 1D hydraulic model with a 2D hydraulic model for the simulation of extreme glacial outburst floods." Hydrological Processes, 22, 10, 15371547.

Bednarek, A.T. (2001). "Undamming Rivers: A Review of the Ecological Impacts of Dam Removal.” Environmental Management, 27(6), 803-814.

Birkland, T., Burby, R., Conrad, D., Cortner, H., and Michener, W. (2003). "River Ecology and Flood Hazard Mitigation.” Nat. Hazards Rev., 4(1), 46-54.

Casas, A., Benito, G., Thorndycraft, V.R., Rico, M. (2006). "The topographic data source of digital terrain models as a key element in the accuracy of hydraulic flood modelling." Earth Surf. Process. Landforms, 31(4), 444-456.

Climate Change Science Program, Subcommittee on Global Change Research. (2003). "Landuse/land cover change." Strategic Plan for the U.S. Climate Change Science Program, Washington, D. C., 63- 70.

Ferrari, J.R., Lookingbill, T.R., McCormick, B., Townsend, P.A., Eshleman, K.N. (2009). "Surface mining and reclamation effects on flood response of watersheds in the central Appalachian Plateau region." Water Resources Research, 45, 1-11.

Graf, W.L. (2001). "Damage Control: Restoring the Physical Integrity of America's Rivers." Annals of the Association of American Geographers, 91(1), 1-27.

Istomina, M.N., Kocharyan, A.G., Lebedeva, I.P. (2005). "Floods: Genesis, Socioeconomic and Environmental Impacts.” Water Resources, 32(4), 349-358.

Junk, W.J., Bayley, P.B., Sparks, R.E. (1989). "The Flood Pulse Concept in River-Floodplain Systems.” Can. Spec. Publ. Fish. Aquat. Sci., 106, 110-127.

Kharin, V.V., Zwiers, F.W. (2005). "Estimating Extremes in Transient Climate Change Simulations." Journal of Climate, 18, 1156-1173.

Knebl, M.R., Yang, Z.-L., Hutchinson, K., Maidment, D.R., (2005). "Regional scale flood modeling using NEXRAD rainfall, GIS, and HEC-HMS/RAS: a case study for the San Antonio River Basin Summer 2002 storm event." Journal of Environmental Management, 75, 4, 325-336.

Leonard, J., Law, K. (2012). "Spatial and Temporal Variations in West Virginia's Precipitation, 1931-2000.” Southeastern Geographer, 52(1), 5-19.

Maingi, J.K., Marsh, S.E., (2002). "Quantifying hydrologic impacts following dam construction along the Tana River, Kenya." Journal of Arid Environments, 50, 53-79. 
Malekmohammadi, B., Zahraie, B., Kerachian, R., (2010). "A real-time operation optimization model for flood management in river-reservoir systems." Natural Hazards, 53, 3, 459482.

Merwade,V.M., Maidment, D.R., Hodges, B.R. (2005). “Geospatial representation of river channels." Journal of Hydrologic Engineering, 10(3), 243-251.

Merwade, V., Olivera, F., Arabi, M., and Edleman, S. (2008). "Uncertainty in Flood Inundation Mapping: Current Issues and Future Directions.” J. Hydrol. Eng., 13(7), 608-620.

Noman, N., Nelson, E., and Zundel, A. (2001). "Review of Automated Floodplain Delineation from Digital Terrain Models." J. Water Resour. Plann. Manage., 127(6), 394-402.

Owusu, P. A., Odai, S. N., Annor, F. O. and Adjei, K. A. (2013), "Reservoir storage for managing floods in urban areas: a case study of Dzorwulu basin in Accra." Hydrol. Process., 27: 1615-1625. doi: 10.1002/hyp.9286

Phillips, J.D. (2004). "Impacts of surface mine valley fills on headwater floods in eastern Kentucky”. Environmental Geology, 45(3), 367-380.

Pitchford, J.L., Wu, C., Lin, L., Petty, J.T., Thomas, R., Veselka, W.E., Welsch, D., Zegre, N., Anderson, J.T. (2012). "Climate Change Effects on Hydrology and Ecology of Wetlands in the Mid-Atlantic Highlands." Wetlands, 32, 21-33.

Saleh, F., Ducharnes, A., Flipo, N., Oudin, L., Ledoux, E. (2013). "Impact of river bed morphology on discharge and water levels simulated by a 1D Saint-Venant hydraulic model at regional scale." Journal of Hydrology, 476, 169-177

Samuels, P.G., 1989. "Backwater lengths in rivers", Proceedings -- Institution of Civil Engineers, Part 2, Research and Theory, 87, 571-582.

Sears, A.E. (2012). “The Integration of Geomorphic Design into West Virginia Surface Mine Reclamation.” Master's thesis. West Virginia University, Morgantown, WV.

Shafroth, P.B. Wilcox, A.C., Lytle, D.A., Hickey, J.T., Andersen, D.C., Beauchamp, V.B., Hautzinger, A., McMullen, L.E., Warner, A. (2010). "Ecosystem effects of environmental flows: modelling and experimental floods in a dryland river." Freshwater Biology, 55, 68-85.

Shatnawi, F.M., Goodall, J.L. (2010). "Comparison of Flood Top Width Predictions Using Surveyed and LiDAR-Derived Channel Geometries.” J. Hydrol. Eng., 15(2), 97-106.

Shellberg, J. G., Brooks, A. P., Spencer, J. and Ward, D. (2013). "The hydrogeomorphic influences on alluvial gully erosion along the Mitchell River fluvial megafan."

Hydrological Processes, 27 (7), 1086-1104 
Snyder, M.W. (2013). "Hydrologic Response of Alternative Valley Fill Reclamation Designs." Master's thesis. West Virginia University, Morgantown, WV.

Tate, E. (1999). "Floodplain Mapping Using HEC-RAS and ArcView GIS.” M.S. Thesis. University of Texas at Austin, Austin, TX.

Tate, E.C., Maidment, D.R., Olivera, F., Anderson, D.J. (2002). "Creating a terrain model for floodplain mapping.” Journal of Hydrologic Engineering, 7(2), 100-108.

United States Army Corps of Engineers (USACE). "HEC-RAS River Analysis System Hydraulic Reference Manual.” Version 4.1. Jan 2010.

USACE. “HEC-RAS River Analysis System User's Manual.” Version 4.1. Jan 2010.

U.S. Geological Survey (2011). “NSS, Version 6.” National Streamflow Statistics Program <http://water.usgs.gov/software/NSS/> (July 21, 2014).

Wurbs, R.A., James, W.P. (2002). “Water Resources Engineering.” Prentice Hall, Inc., Upper Saddle River, NJ.

Yang, J., Townsend, R.D., Daneshfar, B. (2006). "Applying the HEC-RAS model and GIS techniques in river network floodplain delineation." Can. J. Civ. Eng., 33(1), 19-28.

Yochum, S.E., Goertz, L.A., Jones, P.H., (2008). "Case Study of the Big Bay Dam Failure: Accuracy and Comparison of Breach Predictions." Journal of Hydraulic Engineering, $134,9,1285-1293$. 


\section{Appendix A - Maps from Unsteady Storms 5-, 10-, and 25-yr Storm Events}

Modeling was also completed for the 5-, 10-, and 25-year storm events. These storms were not discussed in the main text of this thesis, but the results are reported in the following figures.

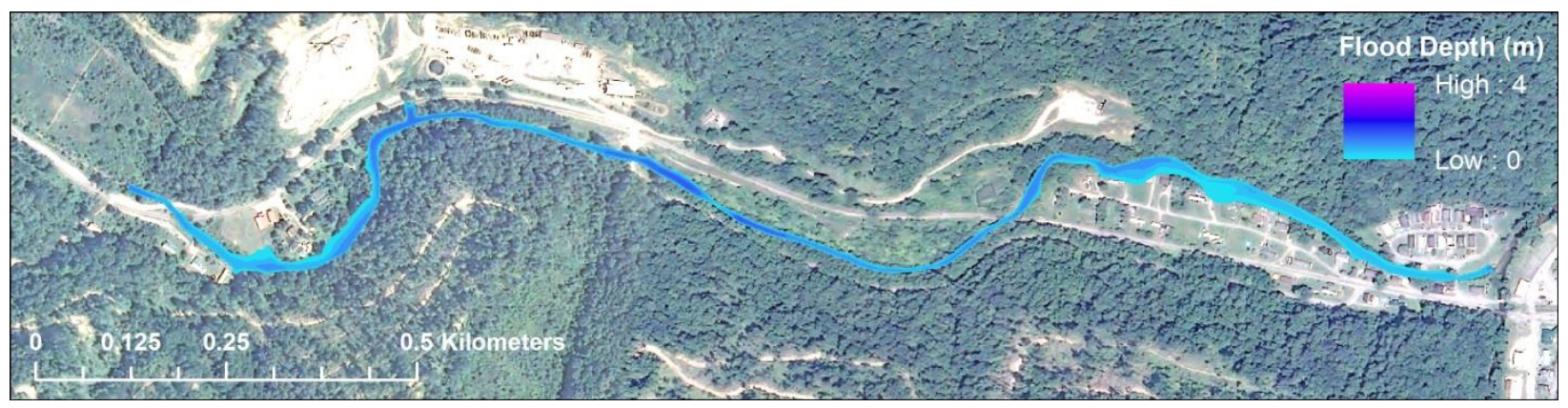

Figure 40: Pre-Mining 5-year unsteady maximum water level flood extents and depth

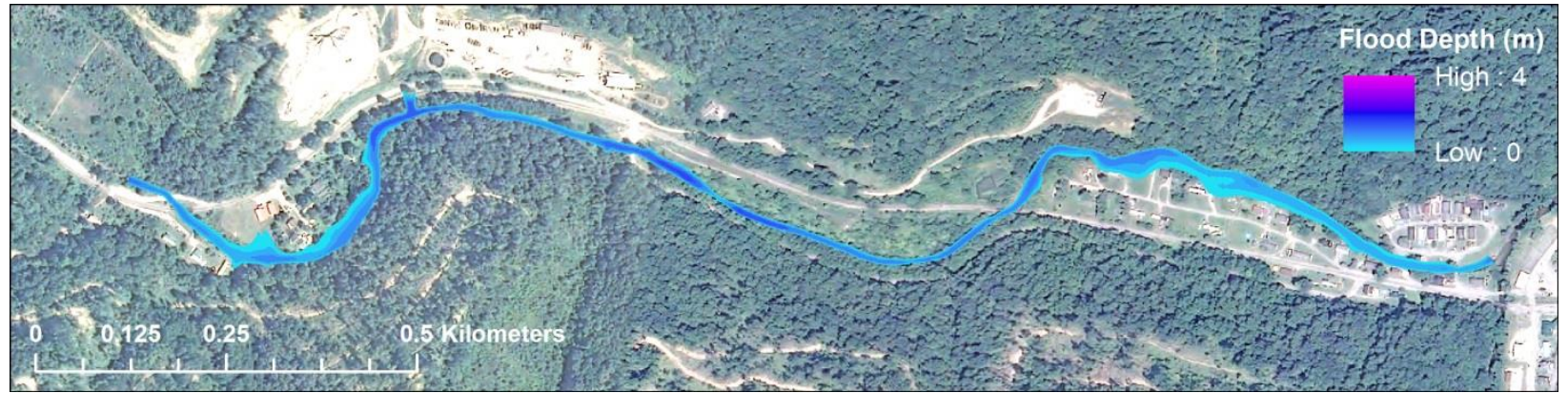

Figure 41: Pre-Mining 10-year unsteady maximum water level flood extents and depth

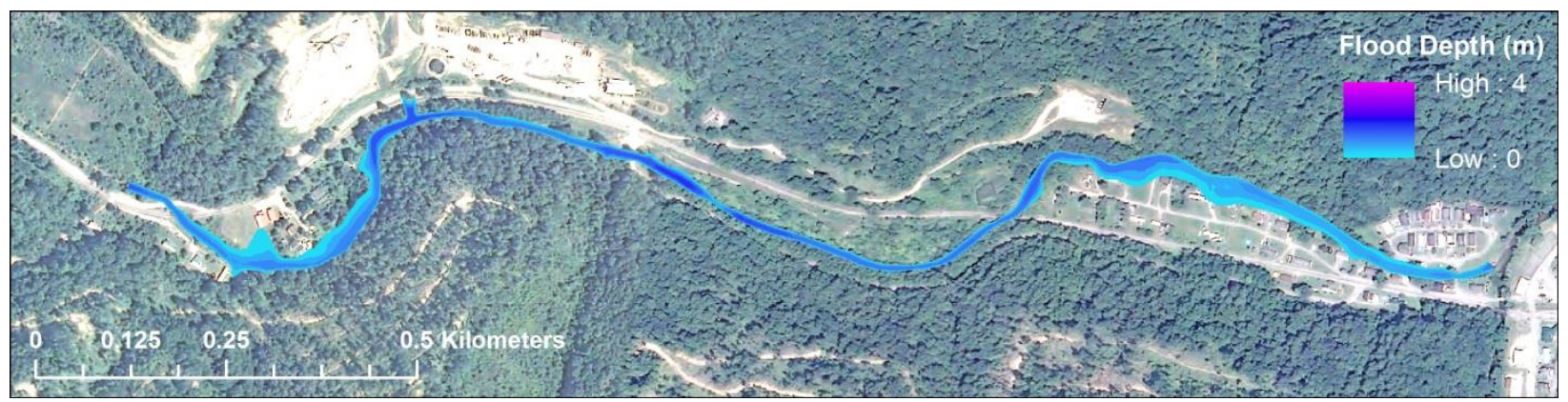

Figure 42: Pre-Mining 25-year unsteady maximum water level flood extents and depth 


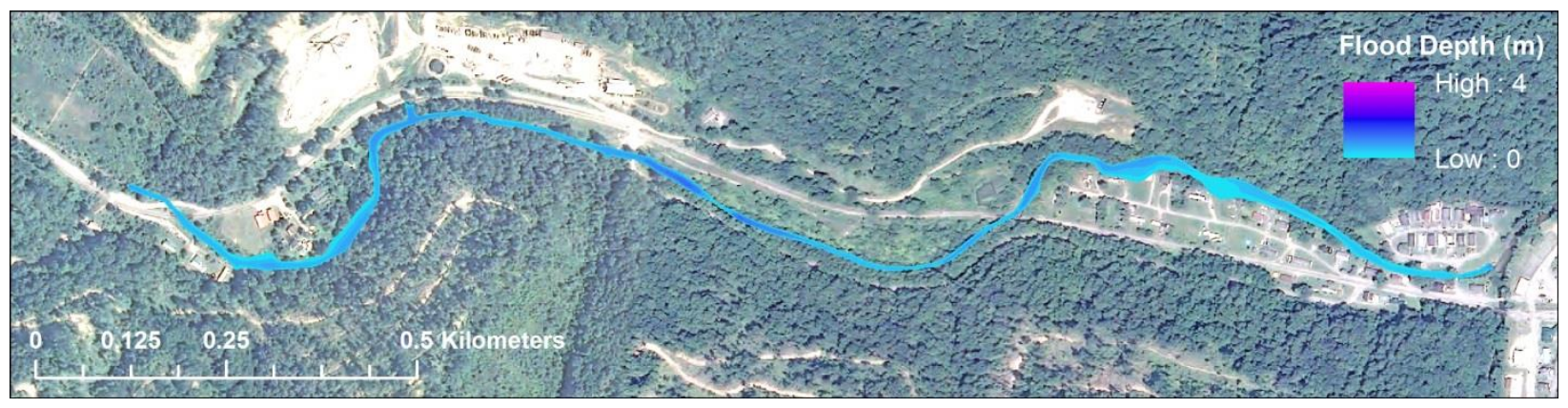

Figure 43: Conventional 5-year maximum unsteady flood extents and depth

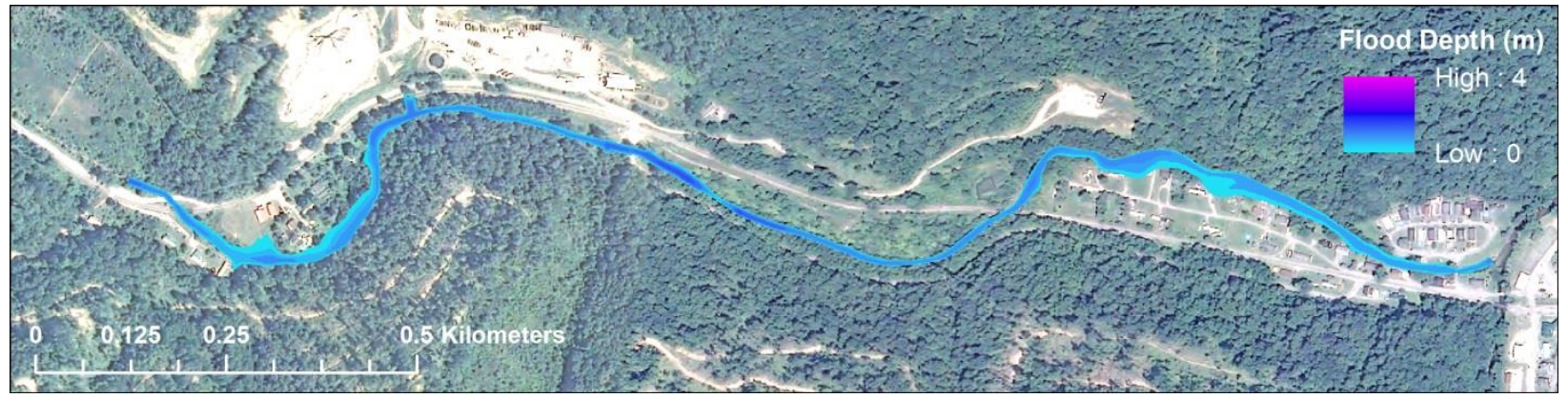

Figure 44: Conventional 10-year maximum unsteady flood extents and depth

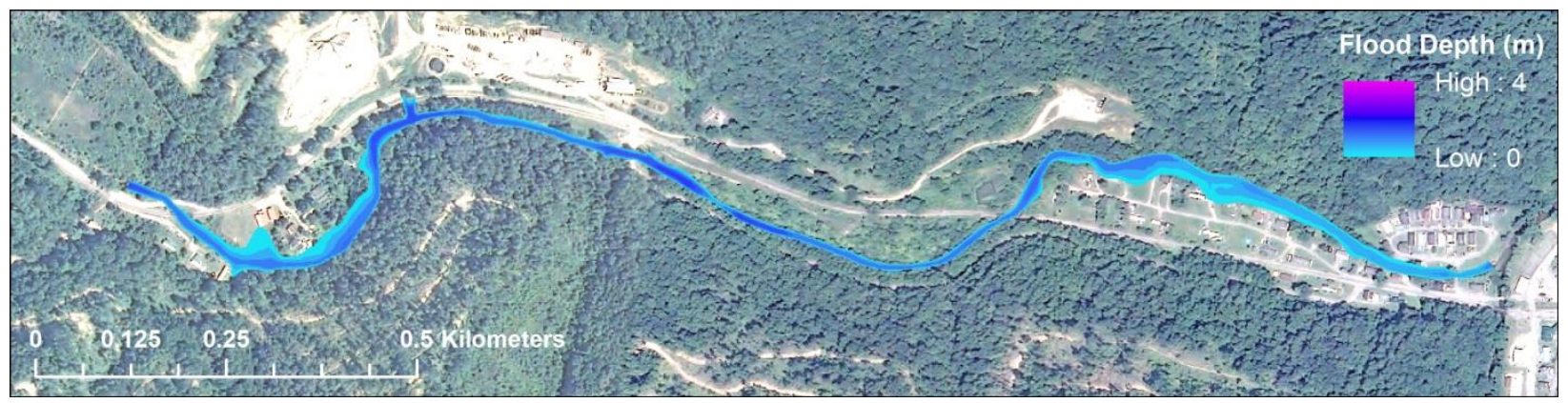

Figure 45: Conventional 25-year maximum unsteady flood extents and depth

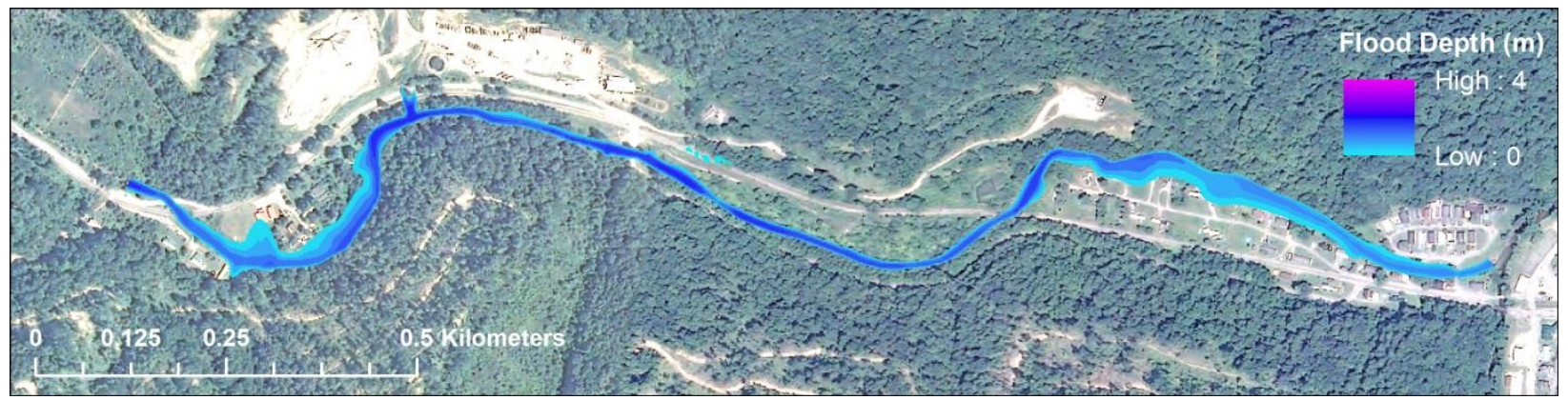

Figure 46: GLD (During mining) 5-year maximum unsteady flood extents and depth 


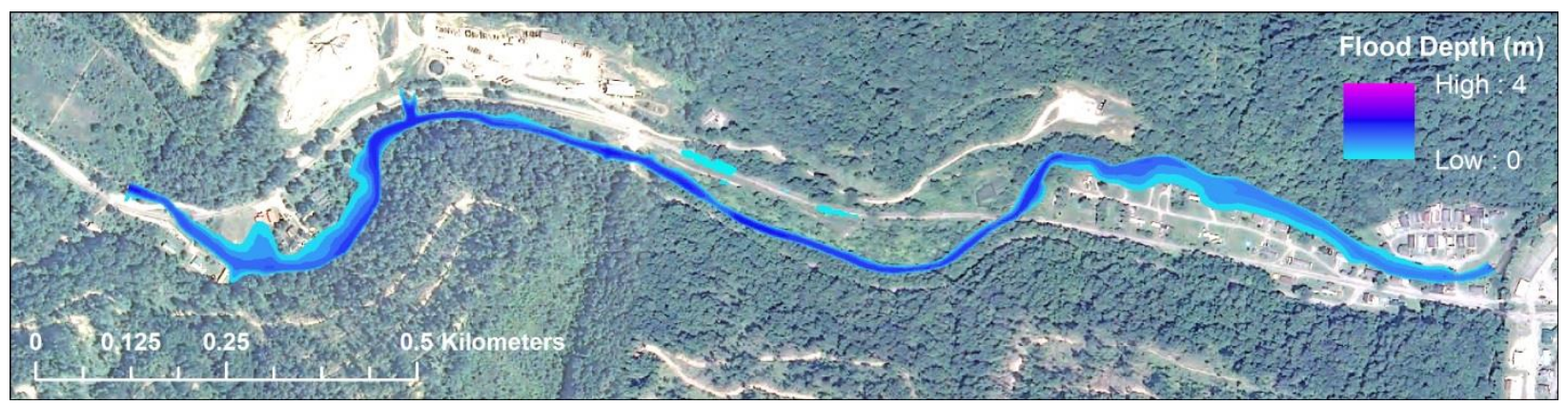

Figure 47: GLD (During mining) 10-year maximum unsteady flood extents and depth

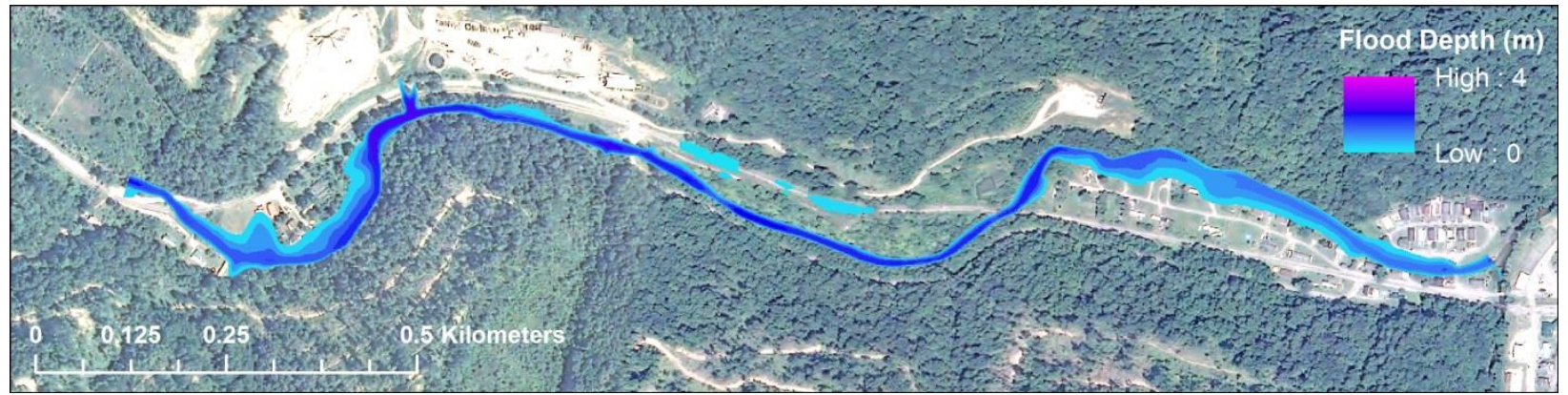

Figure 48: GLD (During mining) 25-year maximum unsteady flood extents and depth

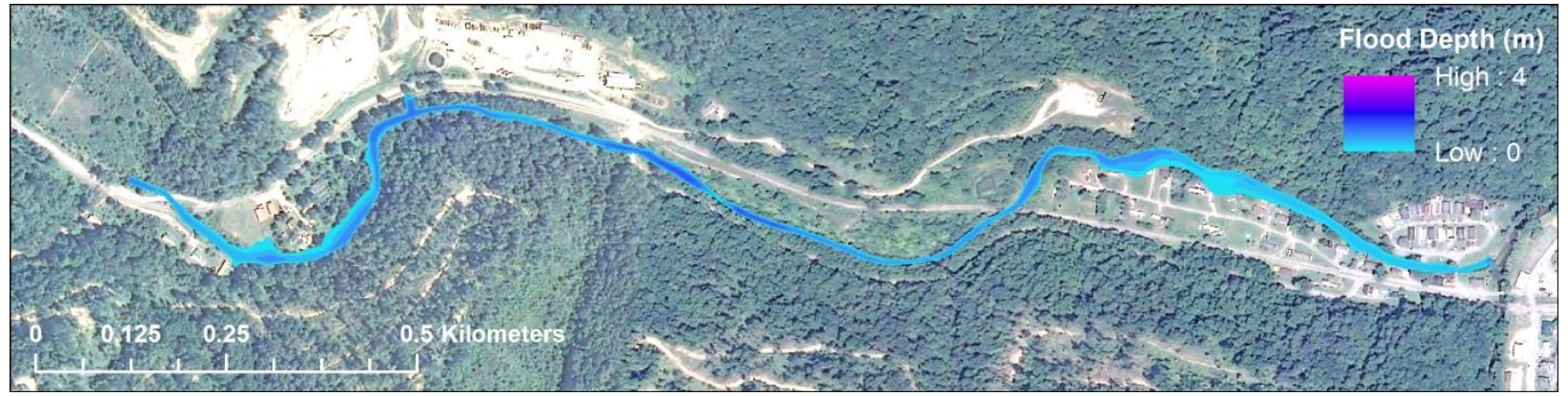

Figure 49: GLD (Post mining) 5-year maximum unsteady flood extents and depth 


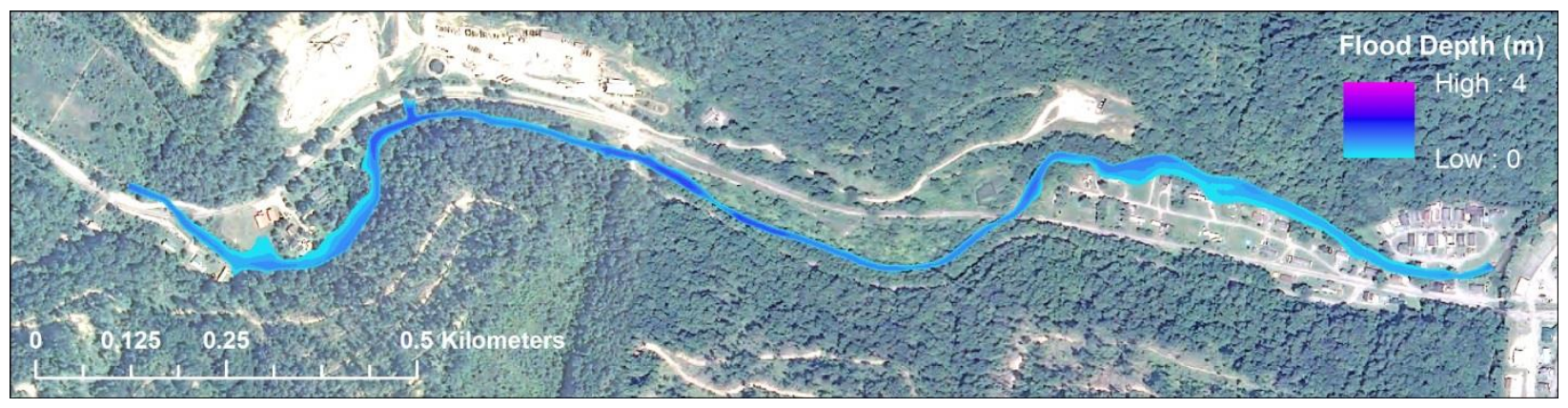

Figure 50: GLD (Post mining) 10-year maximum unsteady flood extents and depth

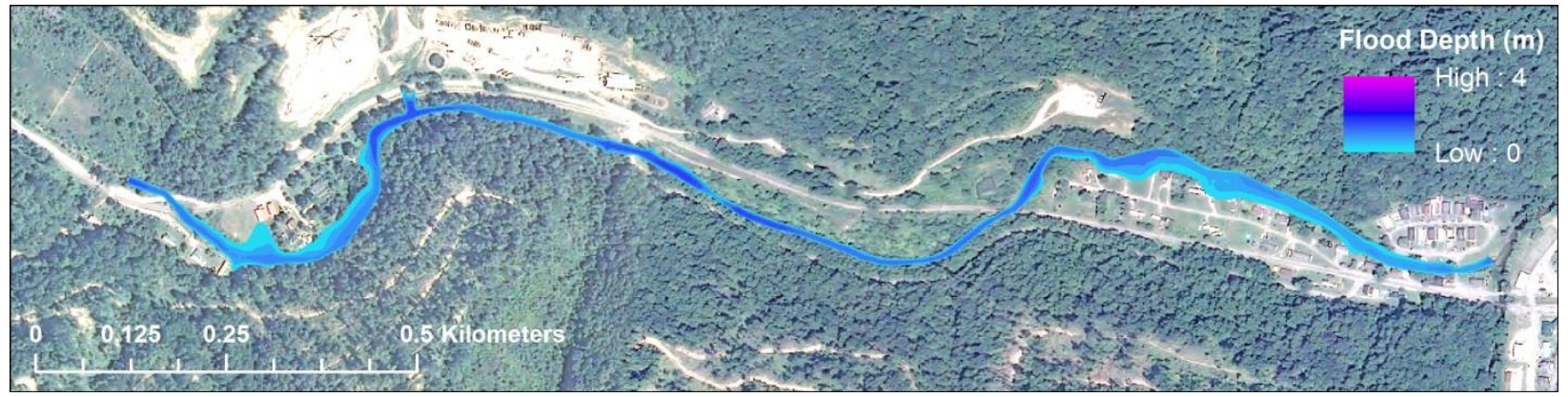

Figure 51: GLD (Post mining) 25-year maximum unsteady flood extents and depth 


\section{Appendix B - Cross-Sectional Outputs}

Table 20: Steady Pre-mining cross-sectional properties

\begin{tabular}{|c|c|c|c|c|c|c|c|c|}
\hline River Sta & Profile & $\begin{array}{c}\text { Q Total } \\
\left(\mathrm{m}^{3} / \mathrm{s}\right)\end{array}$ & $\begin{array}{c}\text { Min Ch } \\
\text { El } \\
(\mathbf{m})\end{array}$ & $\begin{array}{l}\text { W.S. } \\
\text { Elev } \\
(\mathbf{m})\end{array}$ & $\begin{array}{c}\text { Vel } \\
\text { Chnl } \\
(\mathbf{m} / \mathbf{s})\end{array}$ & $\begin{array}{l}\text { Flow } \\
\text { Area } \\
\left(\mathbf{m}^{2}\right) \\
\end{array}$ & $\begin{array}{c}\text { Top } \\
\text { Width } \\
(\mathbf{m}) \\
\end{array}$ & $\begin{array}{c}\text { Max Chl } \\
\text { Dpth } \\
(\mathbf{m}) \\
\end{array}$ \\
\hline 2097.011 & $2-y r$ & 3.78 & 264.87 & 265.55 & 1 & 3.79 & 8.3 & 0.68 \\
\hline 2097.011 & $100-y r$ & 24.88 & 264.87 & 266.45 & 1.82 & 13.67 & 13.82 & 1.58 \\
\hline 2097.011 & $500-\mathrm{yr}$ & 36.41 & 264.87 & 266.74 & 2.02 & 18.04 & 15.69 & 1.87 \\
\hline 2052.742 & $2-y r$ & 3.78 & 264.51 & 265.04 & 1.77 & 2.13 & 6.77 & 0.53 \\
\hline 2052.742 & $100-y r$ & 24.88 & 264.51 & 265.78 & 2.83 & 8.8 & 10.96 & 1.27 \\
\hline 2052.742 & $500-\mathrm{yr}$ & 36.41 & 264.51 & 266.03 & 3.09 & 11.8 & 12.34 & 1.52 \\
\hline 2009.086 & $2-y r$ & 3.78 & 263.84 & 264.3 & 1.11 & 3.39 & 10.74 & 0.46 \\
\hline 2009.086 & $100-\mathrm{yr}$ & 24.88 & 263.84 & 264.94 & 2.02 & 12.33 & 17.11 & 1.1 \\
\hline 2009.086 & $500-\mathrm{yr}$ & 36.41 & 263.84 & 265.12 & 2.37 & 15.41 & 18.68 & 1.28 \\
\hline 1964.49 & $2-\mathrm{yr}$ & 3.78 & 263.35 & 263.74 & 1.29 & 2.92 & 11.31 & 0.39 \\
\hline 1964.49 & $100-\mathrm{yr}$ & 24.88 & 263.35 & 264.25 & 2.34 & 10.62 & 19.23 & 0.9 \\
\hline 1964.49 & $500-y r$ & 36.41 & 263.35 & 264.43 & 2.54 & 14.31 & 22.12 & 1.08 \\
\hline 1925.761 & $2-\mathrm{yr}$ & 3.78 & 263.04 & 263.42 & 0.75 & 5.02 & 20.49 & 0.38 \\
\hline 1925.761 & $100-\mathrm{yr}$ & 24.88 & 263.04 & 263.99 & 1.18 & 23.54 & 45.07 & 0.95 \\
\hline 1925.761 & $500-y r$ & 36.41 & 263.04 & 264.17 & 1.3 & 32.65 & 55.54 & 1.13 \\
\hline 1874.546 & $2-y r$ & 3.78 & 262.4 & 262.97 & 0.74 & 5.12 & 15.18 & 0.57 \\
\hline 1874.546 & $100-y r$ & 24.88 & 262.4 & 263.56 & 1.42 & 17.91 & 28.91 & 1.16 \\
\hline 1874.546 & $500-y r$ & 36.41 & 262.4 & 263.72 & 1.67 & 22.95 & 34.19 & 1.32 \\
\hline 1828.159 & $2-y r$ & 3.78 & 262.13 & 262.51 & 1.47 & 2.57 & 11.85 & 0.38 \\
\hline 1828.159 & $100-y r$ & 24.88 & 262.13 & 262.99 & 2.17 & 11.47 & 25.23 & 0.86 \\
\hline 1828.159 & $500-\mathrm{yr}$ & 36.41 & 262.13 & 263.14 & 2.39 & 15.55 & 29.06 & 1.01 \\
\hline 1788.723 & $2-y r$ & 3.78 & 261.54 & 262.21 & 0.54 & 6.97 & 19.69 & 0.67 \\
\hline 1788.723 & $100-y r$ & 24.88 & 261.54 & 262.91 & 0.97 & 26.98 & 36.35 & 1.37 \\
\hline 1788.723 & $500-\mathrm{yr}$ & 36.41 & 261.54 & 263.16 & 1.08 & 36.61 & 40.96 & 1.62 \\
\hline 1742.556 & $2-y r$ & 3.78 & 261.5 & 262.1 & 0.63 & 6.02 & 16.9 & 0.6 \\
\hline 1742.556 & $100-y r$ & 24.88 & 261.5 & 262.8 & 1.12 & 22.73 & 30.99 & 1.3 \\
\hline 1742.556 & $500-\mathrm{yr}$ & 36.41 & 261.5 & 263.05 & 1.22 & 31.41 & 36.24 & 1.55 \\
\hline
\end{tabular}




\begin{tabular}{|c|c|c|c|c|c|c|c|c|}
\hline River Sta & Profile & $\begin{array}{c}\text { Q Total } \\
\left(\mathbf{m}^{3} / \mathbf{s}\right)\end{array}$ & $\begin{array}{c}\text { Min Ch } \\
\text { El } \\
(\mathbf{m})\end{array}$ & $\begin{array}{l}\text { W.S. } \\
\text { Elev } \\
(\mathbf{m})\end{array}$ & $\begin{array}{c}\text { Vel } \\
\text { Chnl } \\
(\mathbf{m} / \mathbf{s}) \\
\end{array}$ & $\begin{array}{l}\text { Flow } \\
\text { Area } \\
\left(\mathbf{m}^{2}\right) \\
\end{array}$ & $\begin{array}{c}\text { Top } \\
\text { Width } \\
\text { (m) } \\
\end{array}$ & $\begin{array}{c}\text { Max Chl } \\
\text { Dpth } \\
(\mathrm{m}) \\
\end{array}$ \\
\hline 1695.655 & $2-y r$ & 3.78 & 261.28 & 261.71 & 1.61 & 2.35 & 9.16 & 0.43 \\
\hline 1695.655 & $100-\mathrm{yr}$ & 24.88 & 261.28 & 262.46 & 1.92 & 13.29 & 21.7 & 1.18 \\
\hline 1695.655 & $500-\mathrm{yr}$ & 36.41 & 261.28 & 262.82 & 1.8 & 23.49 & 48.08 & 1.54 \\
\hline 1651.05 & $2-y r$ & 3.78 & 260.78 & 261.37 & 0.68 & 5.57 & 14.43 & 0.59 \\
\hline 1651.05 & $100-\mathrm{yr}$ & 24.88 & 260.78 & 262.44 & 0.95 & 26.23 & 24.13 & 1.66 \\
\hline 1651.05 & $500-\mathrm{yr}$ & 36.41 & 260.78 & 262.79 & 1.03 & 35.47 & 27.46 & 2.01 \\
\hline 1617.21 & $2-y r$ & 3.78 & 260.56 & 261.28 & 0.72 & 5.27 & 11.57 & 0.72 \\
\hline 1617.21 & $100-\mathrm{yr}$ & 24.88 & 260.56 & 262.37 & 1.08 & 23.11 & 20.87 & 1.81 \\
\hline 1617.21 & $500-\mathrm{yr}$ & 36.41 & 260.56 & 262.73 & 1.17 & 30.99 & 23.19 & 2.17 \\
\hline 1577.381 & $2-y r$ & 3.78 & 260.48 & 261.29 & 0.22 & 17.14 & 27.32 & 0.81 \\
\hline 1577.381 & $100-\mathrm{yr}$ & 24.88 & 260.48 & 262.39 & 0.47 & 53.41 & 40.53 & 1.91 \\
\hline 1577.381 & $500-y r$ & 36.41 & 260.48 & 262.75 & 0.54 & 71.22 & 55.22 & 2.27 \\
\hline 1542.946 & $2-y r$ & 3.78 & 260.49 & 261.2 & 1.16 & 3.26 & 6.47 & 0.71 \\
\hline 1542.946 & $100-y r$ & 24.88 & 260.49 & 262.08 & 2.32 & 10.74 & 10.43 & 1.59 \\
\hline 1542.946 & $500-y r$ & 36.41 & 260.49 & 262.35 & 2.66 & 13.69 & 11.3 & 1.86 \\
\hline 1504.079 & $2-y r$ & 3.78 & 260.31 & 260.94 & 1.18 & 3.2 & 8.06 & 0.63 \\
\hline 1504.079 & $100-\mathrm{yr}$ & 24.88 & 260.31 & 261.73 & 2.26 & 11 & 11.66 & 1.42 \\
\hline 1504.079 & $500-y r$ & 36.41 & 260.31 & 261.96 & 2.64 & 13.8 & 12.72 & 1.65 \\
\hline 1467.659 & $2-y r$ & 3.78 & 260.12 & 260.68 & 1.08 & 3.51 & 9.07 & 0.56 \\
\hline 1467.659 & $100-\mathrm{yr}$ & 24.88 & 260.12 & 261.5 & 1.85 & 13.42 & 15.65 & 1.38 \\
\hline 1467.659 & $500-\mathrm{yr}$ & 36.41 & 260.12 & 261.74 & 2.09 & 17.44 & 18.19 & 1.62 \\
\hline 1425.307 & $2-y r$ & 3.78 & 259.66 & 260.24 & 1.43 & 2.64 & 7.56 & 0.58 \\
\hline 1425.307 & $100-\mathrm{yr}$ & 24.88 & 259.66 & 260.96 & 2.4 & 10.37 & 14.84 & 1.3 \\
\hline 1425.307 & $500-y r$ & 36.41 & 259.66 & 261.15 & 2.76 & 13.7 & 20.65 & 1.49 \\
\hline 1392.843 & $2-y r$ & 3.78 & 259.14 & 259.68 & 1.61 & 2.35 & 7.45 & 0.54 \\
\hline 1392.843 & $100-\mathrm{yr}$ & 24.88 & 259.14 & 260.4 & 2.63 & 9.47 & 12.05 & 1.26 \\
\hline 1392.843 & $500-\mathrm{yr}$ & 36.41 & 259.14 & 260.71 & 2.67 & 13.65 & 15.18 & 1.57 \\
\hline 1358.799 & $2-y r$ & 3.78 & 258.63 & 259.23 & 1.31 & 2.88 & 7.98 & 0.6 \\
\hline 1358.799 & $100-\mathrm{yr}$ & 24.88 & 258.63 & 259.93 & 2.49 & 10.01 & 12.26 & 1.3 \\
\hline 1358.799 & $500-\mathrm{yr}$ & 36.41 & 258.63 & 260.11 & 2.95 & 12.32 & 13.54 & 1.48 \\
\hline
\end{tabular}




\begin{tabular}{|c|c|c|c|c|c|c|c|c|}
\hline River Sta & Profile & $\begin{array}{c}\text { Q Total } \\
\left(\mathbf{m}^{3} / \mathbf{s}\right)\end{array}$ & $\begin{array}{c}\text { Min Ch } \\
\text { El } \\
(\mathbf{m})\end{array}$ & $\begin{array}{l}\text { W.S. } \\
\text { Elev } \\
(\mathbf{m})\end{array}$ & $\begin{array}{c}\text { Vel } \\
\text { Chnl } \\
(\mathbf{m} / \mathbf{s})\end{array}$ & $\begin{array}{c}\text { Flow } \\
\text { Area } \\
\left(\mathbf{m}^{2}\right)\end{array}$ & $\begin{array}{c}\text { Top } \\
\text { Width } \\
\text { (m) }\end{array}$ & $\begin{array}{c}\text { Max Chl } \\
\text { Dpth } \\
\text { (m) }\end{array}$ \\
\hline 1329.439 & $2-y r$ & 3.78 & 258.21 & 258.7 & 1.72 & 2.19 & 7.4 & 0.48 \\
\hline 1329.439 & $100-\mathrm{yr}$ & 24.88 & 258.21 & 259.4 & 2.75 & 9.03 & 11.9 & 1.19 \\
\hline 1329.439 & $500-\mathrm{yr}$ & 36.41 & 258.21 & 259.72 & 2.75 & 13.26 & 13.85 & 1.51 \\
\hline 1302.462 & $2-y r$ & 3.78 & 257.76 & 258.51 & 0.6 & 6.25 & 12.02 & 0.75 \\
\hline 1302.462 & $100-\mathrm{yr}$ & 24.88 & 257.76 & 259.49 & 1.18 & 21 & 18.35 & 1.73 \\
\hline 1302.462 & $500-\mathrm{yr}$ & 36.41 & 257.76 & 259.82 & 1.33 & 27.41 & 20.63 & 2.06 \\
\hline 1264.23 & $2-y r$ & 3.78 & 257.59 & 258.1 & 1.73 & 2.19 & 6.9 & 0.51 \\
\hline 1264.23 & $100-\mathrm{yr}$ & 24.88 & 257.59 & 258.92 & 2.51 & 9.93 & 11.54 & 1.33 \\
\hline 1264.23 & $500-\mathrm{yr}$ & 36.41 & 257.59 & 259.16 & 2.86 & 12.73 & 12.68 & 1.57 \\
\hline 1230.005 & $2-y r$ & 3.78 & 257.24 & 257.91 & 0.93 & 4.08 & 9.07 & 0.67 \\
\hline 1230.005 & $100-\mathrm{yr}$ & 24.88 & 257.24 & 258.79 & 1.71 & 14.57 & 14.49 & 1.55 \\
\hline 1230.005 & $500-\mathrm{yr}$ & 36.41 & 257.24 & 259 & 2.05 & 17.79 & 15.62 & 1.76 \\
\hline 1191.977 & $2-y r$ & 3.78 & 256.91 & 257.8 & 0.52 & 7.22 & 11.98 & 0.89 \\
\hline 1191.977 & $100-\mathrm{yr}$ & 24.88 & 256.91 & 258.56 & 1.36 & 19.07 & 28.5 & 1.65 \\
\hline 1191.977 & $500-\mathrm{yr}$ & 36.41 & 256.91 & 258.72 & 1.66 & 24.43 & 39.11 & 1.81 \\
\hline 1155.309 & $2-y r$ & 3.78 & 257.11 & 257.65 & 1.31 & 2.88 & 7.71 & 0.54 \\
\hline 1155.309 & $100-\mathrm{yr}$ & 24.88 & 257.11 & 258.34 & 1.87 & 16.45 & 37.29 & 1.23 \\
\hline 1155.309 & $500-y r$ & 36.41 & 257.11 & 258.57 & 1.74 & 26.23 & 45.69 & 1.46 \\
\hline 1124.025 & $2-y r$ & 3.78 & 255.94 & 256.48 & 1.76 & 2.15 & 7.02 & 0.54 \\
\hline 1124.025 & $100-\mathrm{yr}$ & 24.88 & 255.94 & 257.23 & 2.88 & 8.63 & 10.2 & 1.29 \\
\hline 1124.025 & $500-\mathrm{yr}$ & 36.41 & 255.94 & 257.5 & 3.16 & 11.5 & 11.31 & 1.56 \\
\hline 1083.982 & $2-\mathrm{yr}$ & 3.78 & 255 & 255.79 & 0.85 & 4.46 & 8.3 & 0.79 \\
\hline 1083.982 & $100-\mathrm{yr}$ & 24.88 & 255 & 256.78 & 1.69 & 14.72 & 12.44 & 1.78 \\
\hline 1083.982 & $500-\mathrm{yr}$ & 36.41 & 255 & 257.09 & 1.93 & 18.83 & 13.76 & 2.09 \\
\hline 1018.257 & $2-y r$ & 3.78 & 254.8 & 255.42 & 1.31 & 2.88 & 7.68 & 0.62 \\
\hline 1018.257 & $100-\mathrm{yr}$ & 24.88 & 254.8 & 256.26 & 2.32 & 10.74 & 11.02 & 1.46 \\
\hline 1018.257 & $500-\mathrm{yr}$ & 36.41 & 254.8 & 256.5 & 2.66 & 14.47 & 21.63 & 1.7 \\
\hline 959.582 & $2-y r$ & 3.78 & 254.42 & 255.05 & 0.96 & 3.92 & 9.2 & 0.63 \\
\hline 959.582 & $100-\mathrm{yr}$ & 24.88 & 254.42 & 255.97 & 1.7 & 14.84 & 19.58 & 1.55 \\
\hline 959.582 & $500-y r$ & 36.41 & 254.42 & 256.3 & 1.76 & 23.6 & 34 & 1.88 \\
\hline
\end{tabular}




\begin{tabular}{|c|c|c|c|c|c|c|c|c|}
\hline River Sta & Profile & $\begin{array}{c}\text { Q Total } \\
\left(\mathbf{m}^{3} / \mathbf{s}\right)\end{array}$ & $\begin{array}{c}\text { Min Ch } \\
\text { El } \\
(\mathbf{m})\end{array}$ & $\begin{array}{l}\text { W.S. } \\
\text { Elev } \\
(\mathbf{m})\end{array}$ & $\begin{array}{c}\text { Vel } \\
\text { Chnl } \\
(\mathbf{m} / \mathbf{s}) \\
\end{array}$ & $\begin{array}{l}\text { Flow } \\
\text { Area } \\
\left(\mathbf{m}^{2}\right) \\
\end{array}$ & $\begin{array}{c}\text { Top } \\
\text { Width } \\
\text { (m) } \\
\end{array}$ & $\begin{array}{c}\text { Max Chl } \\
\text { Dpth } \\
(\mathbf{m}) \\
\end{array}$ \\
\hline 917.744 & $2-y r$ & 3.78 & 253.94 & 254.63 & 1.11 & 3.4 & 8.22 & 0.69 \\
\hline 917.744 & $100-\mathrm{yr}$ & 24.88 & 253.94 & 255.56 & 1.89 & 13.17 & 12.61 & 1.62 \\
\hline 917.744 & $500-y r$ & 36.41 & 253.94 & 255.87 & 2.1 & 17.63 & 19.23 & 1.93 \\
\hline 885.843 & $2-y r$ & 3.78 & 253.61 & 254.22 & 1.67 & 2.26 & 6.01 & 0.61 \\
\hline 885.843 & $100-\mathrm{yr}$ & 24.88 & 253.61 & 254.99 & 2.9 & 8.58 & 10.17 & 1.38 \\
\hline 885.843 & $500-y r$ & 36.41 & 253.61 & 255.26 & 3.18 & 11.44 & 11.16 & 1.65 \\
\hline 831.018 & $2-y r$ & 3.78 & 252.63 & 253.1 & 1.81 & 2.08 & 6.26 & 0.47 \\
\hline 831.018 & $100-\mathrm{yr}$ & 24.88 & 252.63 & 253.89 & 2.89 & 8.6 & 10.25 & 1.26 \\
\hline 831.018 & $500-y r$ & 36.41 & 252.63 & 254.16 & 3.15 & 11.55 & 11.51 & 1.53 \\
\hline 794.448 & $2-y r$ & 3.78 & 251.86 & 252.49 & 1.07 & 3.54 & 8 & 0.63 \\
\hline 794.448 & $100-\mathrm{yr}$ & 24.88 & 251.86 & 253.39 & 1.86 & 13.35 & 13.5 & 1.53 \\
\hline 794.448 & $500-\mathrm{yr}$ & 36.41 & 251.86 & 253.69 & 2.07 & 17.64 & 14.96 & 1.83 \\
\hline 753.27 & $2-y r$ & 3.78 & 251.5 & 252.15 & 1.31 & 2.88 & 7.46 & 0.65 \\
\hline 753.27 & $100-\mathrm{yr}$ & 24.88 & 251.5 & 252.87 & 2.56 & 9.74 & 11.25 & 1.37 \\
\hline 753.27 & $500-y r$ & 36.41 & 251.5 & 253.09 & 2.96 & 12.3 & 12.22 & 1.59 \\
\hline 720.714 & $2-\mathrm{yr}$ & 3.78 & 251.09 & 251.59 & 1.74 & 2.18 & 7.23 & 0.5 \\
\hline 720.714 & $100-\mathrm{yr}$ & 24.88 & 251.09 & 252.3 & 2.77 & 8.99 & 11.68 & 1.21 \\
\hline 720.714 & $500-y r$ & 36.41 & 251.09 & 252.55 & 3.03 & 12.01 & 13.01 & 1.46 \\
\hline 673.556 & $2-y r$ & 3.78 & 250.52 & 251.22 & 0.49 & 7.76 & 16.92 & 0.7 \\
\hline 673.556 & $100-\mathrm{yr}$ & 24.88 & 250.52 & 252.05 & 0.91 & 27.38 & 30.44 & 1.53 \\
\hline 673.556 & $500-y r$ & 36.41 & 250.52 & 252.31 & 1.02 & 35.61 & 34.8 & 1.79 \\
\hline 625.562 & $2-y r$ & 3.78 & 250.47 & 251.07 & 1 & 3.76 & 10.2 & 0.6 \\
\hline 625.562 & $100-\mathrm{yr}$ & 24.88 & 250.47 & 251.72 & 2 & 12.42 & 16.9 & 1.25 \\
\hline 625.562 & $500-y r$ & 36.41 & 250.47 & 251.86 & 2.45 & 14.85 & 18.7 & 1.39 \\
\hline 582.64 & $2-y r$ & 3.78 & 250.01 & 250.5 & 1.61 & 2.34 & 9.12 & 0.49 \\
\hline 582.64 & $100-\mathrm{yr}$ & 24.88 & 250.01 & 251.11 & 2.37 & 11.05 & 22.28 & 1.1 \\
\hline 582.64 & $500-\mathrm{yr}$ & 36.41 & 250.01 & 251.31 & 2.53 & 16.08 & 28.88 & 1.3 \\
\hline 543.04 & $2-y r$ & 3.78 & 249.4 & 249.87 & 1.01 & 3.75 & 13.53 & 0.47 \\
\hline 543.04 & $100-\mathrm{yr}$ & 24.88 & 249.4 & 250.41 & 1.89 & 13.49 & 22.16 & 1.01 \\
\hline 543.04 & $500-y r$ & 36.41 & 249.4 & 250.55 & 2.27 & 16.78 & 24.18 & 1.15 \\
\hline
\end{tabular}




\begin{tabular}{|c|c|c|c|c|c|c|c|c|}
\hline River Sta & Profile & $\begin{array}{c}\text { Q Total } \\
\left(\mathbf{m}^{3} / \mathbf{s}\right)\end{array}$ & $\begin{array}{c}\text { Min Ch } \\
\text { El } \\
(\mathbf{m})\end{array}$ & $\begin{array}{l}\text { W.S. } \\
\text { Elev } \\
(\mathbf{m})\end{array}$ & $\begin{array}{c}\text { Vel } \\
\text { Chnl } \\
(\mathbf{m} / \mathbf{s})\end{array}$ & $\begin{array}{c}\text { Flow } \\
\text { Area } \\
\left(\mathbf{m}^{2}\right)\end{array}$ & $\begin{array}{c}\text { Top } \\
\text { Width } \\
\text { (m) }\end{array}$ & $\begin{array}{c}\text { Max Chl } \\
\text { Dpth } \\
\text { (m) }\end{array}$ \\
\hline 496.118 & $2-y r$ & 3.78 & 249.1 & 249.66 & 0.63 & 5.99 & 19.56 & 0.56 \\
\hline 496.118 & $100-\mathrm{yr}$ & 24.88 & 249.1 & 250.18 & 1.24 & 20.1 & 34.2 & 1.08 \\
\hline 496.118 & $500-\mathrm{yr}$ & 36.41 & 249.1 & 250.32 & 1.48 & 25.12 & 37.83 & 1.22 \\
\hline 428.594 & $2-y r$ & 3.78 & 248.79 & 249.11 & 1.32 & 2.87 & 16.66 & 0.32 \\
\hline 428.594 & $100-\mathrm{yr}$ & 24.88 & 248.79 & 249.5 & 2.05 & 13.14 & 34.28 & 0.71 \\
\hline 428.594 & $500-\mathrm{yr}$ & 36.41 & 248.79 & 249.63 & 2.22 & 18.07 & 39.51 & 0.84 \\
\hline 389.142 & $2-y r$ & 3.78 & 248.21 & 248.59 & 0.75 & 6 & 29.68 & 0.38 \\
\hline 389.142 & $100-y r$ & 24.88 & 248.21 & 249.15 & 1.07 & 27.23 & 44.66 & 0.94 \\
\hline 389.142 & $500-y r$ & 36.41 & 248.21 & 249.34 & 1.19 & 36.36 & 48.86 & 1.13 \\
\hline 343.978 & $2-y r$ & 3.78 & 247.75 & 248.24 & 0.67 & 5.61 & 17.07 & 0.49 \\
\hline 343.978 & $100-\mathrm{yr}$ & 24.88 & 247.75 & 248.86 & 1.28 & 20.89 & 31.98 & 1.11 \\
\hline 343.978 & $500-\mathrm{yr}$ & 36.41 & 247.75 & 249.06 & 1.47 & 27.47 & 36.12 & 1.31 \\
\hline 318.111 & $2-y r$ & 3.78 & 247.65 & 248.13 & 0.79 & 4.77 & 15.54 & 0.48 \\
\hline 318.111 & $100-y r$ & 24.88 & 247.65 & 248.74 & 1.42 & 18.6 & 29.43 & 1.09 \\
\hline 318.111 & $500-y r$ & 36.41 & 247.65 & 248.93 & 1.62 & 24.43 & 33.02 & 1.28 \\
\hline 284.899 & $2-y r$ & 3.78 & 247.49 & 248.01 & 0.66 & 5.75 & 17.32 & 0.52 \\
\hline 284.899 & $100-\mathrm{yr}$ & 24.88 & 247.49 & 248.64 & 1.19 & 21.5 & 32.14 & 1.15 \\
\hline 284.899 & $500-\mathrm{yr}$ & 36.41 & 247.49 & 248.83 & 1.36 & 28.05 & 36.29 & 1.34 \\
\hline 244.681 & $2-y r$ & 3.78 & 247.05 & 247.43 & 1.53 & 2.48 & 10.7 & 0.38 \\
\hline 244.681 & $100-\mathrm{yr}$ & 24.88 & 247.05 & 247.98 & 2.27 & 10.98 & 20.98 & 0.93 \\
\hline 244.681 & $500-y r$ & 36.41 & 247.05 & 248.15 & 2.44 & 14.9 & 24.93 & 1.1 \\
\hline 214.499 & $2-\mathrm{yr}$ & 3.78 & 246.61 & 247.28 & 0.51 & 7.46 & 18.44 & 0.67 \\
\hline 214.499 & $100-\mathrm{yr}$ & 24.88 & 246.61 & 247.95 & 1.05 & 24.82 & 33.2 & 1.34 \\
\hline 214.499 & $500-y r$ & 36.41 & 246.61 & 248.16 & 1.23 & 32.13 & 38.11 & 1.55 \\
\hline 214.498 & $2-y r$ & 3.78 & 246.61 & 247.02 & 1.12 & 3.38 & 12.95 & 0.41 \\
\hline 214.498 & $100-\mathrm{yr}$ & 24.88 & 246.61 & 247.53 & 1.95 & 12.78 & 23.94 & 0.92 \\
\hline 214.498 & $500-\mathrm{yr}$ & 36.41 & 246.61 & 247.67 & 2.27 & 16.2 & 26.97 & 1.06 \\
\hline 147.881 & $2-y r$ & 3.78 & 245.82 & 246.26 & 1.09 & 3.47 & 13.05 & 0.44 \\
\hline 147.881 & $100-y r$ & 24.88 & 245.82 & 246.88 & 1.61 & 15.46 & 25.68 & 1.06 \\
\hline 147.881 & $500-\mathrm{yr}$ & 36.41 & 245.82 & 247.06 & 1.79 & 20.56 & 29.73 & 1.24 \\
\hline
\end{tabular}




\begin{tabular}{rlrrrrrrr}
\hline River Sta & Profile & $\begin{array}{c}\text { Q Total } \\
\left(\mathbf{m}^{\mathbf{3}} / \mathbf{s}\right)\end{array}$ & $\begin{array}{c}\text { Min Ch } \\
\text { El } \\
(\mathbf{m})\end{array}$ & $\begin{array}{l}\text { W.S. } \\
\mathbf{E l e v} \\
(\mathbf{m})\end{array}$ & $\begin{array}{c}\text { Vel } \\
\text { Chnl } \\
(\mathbf{m} / \mathbf{s})\end{array}$ & $\begin{array}{c}\text { Flow } \\
\text { Area } \\
\left(\mathbf{m}^{2}\right)\end{array}$ & $\begin{array}{c}\text { Top } \\
\text { Width } \\
(\mathbf{m})\end{array}$ & $\begin{array}{c}\text { Max Chl } \\
\text { Dpth } \\
(\mathbf{m})\end{array}$ \\
\hline 79.942 & $2-\mathrm{yr}$ & 3.78 & 245.12 & 245.64 & 1.04 & 3.63 & 10.86 & 0.52 \\
79.942 & $100-\mathrm{yr}$ & 24.88 & 245.12 & 246.41 & 1.58 & 15.72 & 21.24 & 1.29 \\
79.942 & $500-\mathrm{yr}$ & 36.41 & 245.12 & 246.66 & 1.7 & 21.46 & 24.88 & 1.54 \\
& & & & & & & & \\
53.415 & $2-\mathrm{yr}$ & 3.78 & 244.76 & 245.21 & 1.72 & 2.2 & 7.47 & 0.45 \\
53.415 & $100-\mathrm{yr}$ & 24.88 & 244.76 & 245.9 & 2.63 & 9.47 & 13.47 & 1.14 \\
53.415 & $500-\mathrm{yr}$ & 36.41 & 244.76 & 246.13 & 2.85 & 12.79 & 15.57 & 1.37 \\
& & & & & & & & \\
13.63 & $2-\mathrm{yr}$ & 3.78 & 243.93 & 244.4 & 1.41 & 2.69 & 8.31 & 0.47 \\
13.63 & $100-\mathrm{yr}$ & 24.88 & 243.93 & 245.09 & 2.4 & 10.37 & 14.26 & 1.16 \\
13.63 & $500-\mathrm{yr}$ & 36.41 & 243.93 & 245.31 & 2.62 & 14.31 & 23.68 & 1.38
\end{tabular}

Table 21: Steady Conventional cross-sectional properties

\begin{tabular}{rlrrrrrrr}
\hline River Sta & Profile & $\begin{array}{c}\text { Q Total } \\
\left(\mathbf{m}^{3} / \mathbf{s}\right)\end{array}$ & $\begin{array}{c}\text { Min Ch } \\
\text { El } \\
(\mathbf{m})\end{array}$ & $\begin{array}{l}\text { W.S. } \\
\mathbf{E l e v} \\
(\mathbf{m})\end{array}$ & $\begin{array}{c}\text { Vel } \\
\text { Chnl } \\
(\mathbf{m} / \mathbf{s})\end{array}$ & $\begin{array}{c}\text { Flow } \\
\text { Area } \\
\left(\mathbf{m}^{2}\right)\end{array}$ & $\begin{array}{c}\text { Top } \\
\text { Width } \\
(\mathbf{m})\end{array}$ & $\begin{array}{c}\text { Max Chl } \\
\text { Dpth } \\
(\mathbf{m})\end{array}$ \\
\hline 2097.011 & 2 -yr & 1.66 & 264.87 & 265.34 & 0.75 & 2.21 & 6.87 & 0.47 \\
2097.011 & $100-\mathrm{yr}$ & 33.91 & 264.87 & 266.68 & 1.98 & 17.13 & 15.34 & 1.81 \\
2097.011 & $500-\mathrm{yr}$ & 46.94 & 264.87 & 266.98 & 2.15 & 21.86 & 17.71 & 2.11 \\
& & & & & & & & \\
2052.742 & $2-\mathrm{yr}$ & 1.66 & 264.51 & 264.88 & 1.44 & 1.16 & 5.52 & 0.37 \\
2052.742 & $100-\mathrm{yr}$ & 33.91 & 264.51 & 265.98 & 3.04 & 11.16 & 12.06 & 1.47 \\
2052.742 & $500-\mathrm{yr}$ & 46.94 & 264.51 & 266.23 & 3.27 & 14.37 & 13.41 & 1.72 \\
& & & & & & & & \\
2009.086 & $2-\mathrm{yr}$ & 1.66 & 263.84 & 264.14 & 0.91 & 1.83 & 8.79 & 0.3 \\
2009.086 & $100-\mathrm{yr}$ & 33.91 & 263.84 & 265.08 & 2.29 & 14.82 & 18.39 & 1.24 \\
2009.086 & $500-\mathrm{yr}$ & 46.94 & 263.84 & 265.23 & 2.68 & 17.59 & 19.68 & 1.39 \\
& & & & & & & & \\
1964.49 & $2-\mathrm{yr}$ & 1.66 & 263.35 & 263.64 & 0.89 & 1.86 & 9.86 & 0.29 \\
1964.49 & $100-\mathrm{yr}$ & 33.91 & 263.35 & 264.39 & 2.51 & 13.53 & 21.53 & 1.04 \\
1964.49 & $500-\mathrm{yr}$ & 46.94 & 263.35 & 264.57 & 2.66 & 17.63 & 24.47 & 1.22 \\
& & & & & & & & \\
1925.761 & $2-\mathrm{yr}$ & 1.66 & 263.04 & 263.28 & 0.65 & 2.55 & 15.68 & 0.24 \\
1925.761 & $100-\mathrm{yr}$ & 33.91 & 263.04 & 264.13 & 1.28 & 30.67 & 52.8 & 1.09 \\
1925.761 & $500-\mathrm{yr}$ & 46.94 & 263.04 & 264.31 & 1.39 & 41.53 & 70.22 & 1.27 \\
& & & & & & & & \\
1874.546 & $2-\mathrm{yr}$ & 1.66 & 262.4 & 262.81 & 0.56 & 2.96 & 12.25 & 0.41 \\
1874.546 & $100-\mathrm{yr}$ & 33.91 & 262.4 & 263.69 & 1.62 & 21.88 & 33.08 & 1.29 \\
1874.546 & $500-\mathrm{yr}$ & 46.94 & 262.4 & 263.8 & 1.94 & 25.98 & 37.78 & 1.4
\end{tabular}




\begin{tabular}{|c|c|c|c|c|c|c|c|c|}
\hline River Sta & Profile & $\begin{array}{c}\text { Q Total } \\
\left(\mathrm{m}^{3} / \mathrm{s}\right)\end{array}$ & $\begin{array}{c}\text { Min Ch } \\
\text { El } \\
(\mathbf{m})\end{array}$ & $\begin{array}{l}\text { W.S. } \\
\text { Elev } \\
(\mathbf{m})\end{array}$ & $\begin{array}{c}\text { Vel } \\
\text { Chnl } \\
(\mathbf{m} / \mathbf{s})\end{array}$ & $\begin{array}{l}\text { Flow } \\
\text { Area } \\
\left(\mathbf{m}^{2}\right) \\
\end{array}$ & $\begin{array}{c}\text { Top } \\
\text { Width } \\
(\mathbf{m}) \\
\end{array}$ & $\begin{array}{c}\text { Max Chl } \\
\text { Dpth } \\
(\mathbf{m})\end{array}$ \\
\hline 1828.159 & $2-y r$ & 1.66 & 262.13 & 262.39 & 1.24 & 1.34 & 8.78 & 0.26 \\
\hline 1828.159 & $100-\mathrm{yr}$ & 33.91 & 262.13 & 263.11 & 2.35 & 14.65 & 28.24 & 0.98 \\
\hline 1828.159 & $500-y r$ & 46.94 & 262.13 & 263.33 & 2.3 & 21.53 & 34.49 & 1.2 \\
\hline 1788.723 & $2-y r$ & 1.66 & 261.54 & 262.02 & 0.43 & 3.82 & 13.96 & 0.48 \\
\hline 1788.723 & $100-\mathrm{yr}$ & 33.91 & 261.54 & 263.1 & 1.06 & 34.34 & 39.99 & 1.56 \\
\hline 1788.723 & $500-\mathrm{yr}$ & 46.94 & 261.54 & 263.34 & 1.16 & 44.41 & 44.16 & 1.8 \\
\hline 1742.556 & $2-y r$ & 1.66 & 261.5 & 261.93 & 0.49 & 3.38 & 13.03 & 0.43 \\
\hline 1742.556 & $100-\mathrm{yr}$ & 33.91 & 261.5 & 262.99 & 1.21 & 29.25 & 34.94 & 1.49 \\
\hline 1742.556 & $500-y r$ & 46.94 & 261.5 & 263.24 & 1.31 & 38.46 & 39.94 & 1.74 \\
\hline 1695.655 & $2-y r$ & 1.66 & 261.28 & 261.57 & 1.33 & 1.24 & 7.01 & 0.29 \\
\hline 1695.655 & $100-\mathrm{yr}$ & 33.91 & 261.28 & 262.75 & 1.79 & 20.91 & 31.96 & 1.47 \\
\hline 1695.655 & $500-\mathrm{yr}$ & 46.94 & 261.28 & 263.12 & 1.52 & 39.39 & 56.96 & 1.84 \\
\hline 1651.05 & $2-y r$ & 1.66 & 260.78 & 261.16 & 0.6 & 2.76 & 11.29 & 0.38 \\
\hline 1651.05 & $100-y r$ & 33.91 & 260.78 & 262.72 & 1.01 & 33.52 & 26.81 & 1.94 \\
\hline 1651.05 & $500-y r$ & 46.94 & 260.78 & 263.07 & 1.08 & 43.55 & 30.24 & 2.29 \\
\hline 1617.21 & $2-y r$ & 1.66 & 260.56 & 261.04 & 0.62 & 2.68 & 9.17 & 0.48 \\
\hline 1617.21 & $100-\mathrm{yr}$ & 33.91 & 260.56 & 262.66 & 1.16 & 29.34 & 22.73 & 2.1 \\
\hline 1617.21 & $500-\mathrm{yr}$ & 46.94 & 260.56 & 263.01 & 1.24 & 37.79 & 24.97 & 2.45 \\
\hline 1577.381 & $2-y r$ & 1.66 & 260.48 & 261.04 & 0.16 & 10.68 & 24.33 & 0.56 \\
\hline 1577.381 & $100-\mathrm{yr}$ & 33.91 & 260.48 & 262.68 & 0.53 & 67.29 & 53.08 & 2.2 \\
\hline 1577.381 & $500-\mathrm{yr}$ & 46.94 & 260.48 & 263.04 & 0.58 & 88.03 & 63.61 & 2.56 \\
\hline 1542.946 & $2-y r$ & 1.66 & 260.49 & 260.99 & 0.83 & 1.99 & 5.5 & 0.5 \\
\hline 1542.946 & $100-\mathrm{yr}$ & 33.91 & 260.49 & 262.29 & 2.59 & 13.09 & 11.13 & 1.8 \\
\hline 1542.946 & $500-\mathrm{yr}$ & 46.94 & 260.49 & 262.56 & 2.9 & 16.18 & 11.95 & 2.07 \\
\hline 1504.079 & $2-y r$ & 1.66 & 260.31 & 260.76 & 0.89 & 1.86 & 6.87 & 0.45 \\
\hline 1504.079 & $100-\mathrm{yr}$ & 33.91 & 260.31 & 261.92 & 2.55 & 13.3 & 12.53 & 1.61 \\
\hline 1504.079 & $500-\mathrm{yr}$ & 46.94 & 260.31 & 262.1 & 3 & 15.63 & 13.32 & 1.79 \\
\hline 1467.659 & $2-y r$ & 1.66 & 260.12 & 260.5 & 0.84 & 1.98 & 7.76 & 0.38 \\
\hline 1467.659 & $100-\mathrm{yr}$ & 33.91 & 260.12 & 261.7 & 2.03 & 16.71 & 17.58 & 1.58 \\
\hline 1467.659 & $500-\mathrm{yr}$ & 46.94 & 260.12 & 261.85 & 2.41 & 19.63 & 19.93 & 1.73 \\
\hline
\end{tabular}




\begin{tabular}{|c|c|c|c|c|c|c|c|c|}
\hline River Sta & Profile & $\begin{array}{c}\text { Q Total } \\
\left(\mathrm{m}^{3} / \mathrm{s}\right)\end{array}$ & $\begin{array}{c}\text { Min Ch } \\
\text { El } \\
(\mathbf{m})\end{array}$ & $\begin{array}{l}\text { W.S. } \\
\text { Elev } \\
(\mathbf{m})\end{array}$ & $\begin{array}{c}\text { Vel } \\
\text { Chnl } \\
(\mathbf{m} / \mathbf{s})\end{array}$ & $\begin{array}{l}\text { Flow } \\
\text { Area } \\
\left(\mathbf{m}^{2}\right) \\
\end{array}$ & $\begin{array}{c}\text { Top } \\
\text { Width } \\
(\mathbf{m}) \\
\end{array}$ & $\begin{array}{c}\text { Max Chl } \\
\text { Dpth } \\
(\mathbf{m})\end{array}$ \\
\hline 1425.307 & $2-y r$ & 1.66 & 259.66 & 260.08 & 1.09 & 1.52 & 6.18 & 0.42 \\
\hline 1425.307 & $100-\mathrm{yr}$ & 33.91 & 259.66 & 261.1 & 2.71 & 12.87 & 19.27 & 1.44 \\
\hline 1425.307 & $500-y r$ & 46.94 & 259.66 & 261.34 & 2.83 & 18.46 & 28.67 & 1.68 \\
\hline 1392.843 & $2-y r$ & 1.66 & 259.14 & 259.52 & 1.31 & 1.26 & 5.91 & 0.38 \\
\hline 1392.843 & $100-\mathrm{yr}$ & 33.91 & 259.14 & 260.65 & 2.67 & 12.72 & 14.49 & 1.51 \\
\hline 1392.843 & $500-\mathrm{yr}$ & 46.94 & 259.14 & 260.9 & 2.8 & 17.4 & 26.96 & 1.76 \\
\hline 1358.799 & $2-y r$ & 1.66 & 258.63 & 259.06 & 0.99 & 1.67 & 6.63 & 0.43 \\
\hline 1358.799 & $100-\mathrm{yr}$ & 33.91 & 258.63 & 260.07 & 2.88 & 11.78 & 13.19 & 1.44 \\
\hline 1358.799 & $500-\mathrm{yr}$ & 46.94 & 258.63 & 260.3 & 3.14 & 14.97 & 15.1 & 1.67 \\
\hline 1329.439 & $2-y r$ & 1.66 & 258.21 & 258.55 & 1.4 & 1.19 & 6.12 & 0.34 \\
\hline 1329.439 & $100-y r$ & 33.91 & 258.21 & 259.66 & 2.74 & 12.37 & 13.49 & 1.45 \\
\hline 1329.439 & $500-\mathrm{yr}$ & 46.94 & 258.21 & 259.96 & 2.83 & 16.71 & 15.53 & 1.75 \\
\hline 1302.462 & $2-y r$ & 1.66 & 257.76 & 258.29 & 0.45 & 3.71 & 10.48 & 0.53 \\
\hline 1302.462 & $100-y r$ & 33.91 & 257.76 & 259.75 & 1.3 & 26.07 & 20.15 & 1.99 \\
\hline 1302.462 & $500-\mathrm{yr}$ & 46.94 & 257.76 & 260.07 & 1.44 & 32.84 & 22.97 & 2.31 \\
\hline 1264.23 & $2-y r$ & 1.66 & 257.59 & 257.95 & 1.35 & 1.23 & 5.79 & 0.36 \\
\hline 1264.23 & $100-\mathrm{yr}$ & 33.91 & 257.59 & 259.11 & 2.79 & 12.16 & 12.46 & 1.52 \\
\hline 1264.23 & $500-\mathrm{yr}$ & 46.94 & 257.59 & 259.31 & 3.18 & 14.78 & 13.45 & 1.72 \\
\hline 1230.005 & $2-y r$ & 1.66 & 257.24 & 257.66 & 0.8 & 2.08 & 7.14 & 0.42 \\
\hline 1230.005 & $100-\mathrm{yr}$ & 33.91 & 257.24 & 258.96 & 1.98 & 17.15 & 15.4 & 1.72 \\
\hline 1230.005 & $500-\mathrm{yr}$ & 46.94 & 257.24 & 259.14 & 2.35 & 20.02 & 16.69 & 1.9 \\
\hline 1191.977 & $2-y r$ & 1.66 & 256.91 & 257.58 & 0.35 & 4.7 & 10.39 & 0.67 \\
\hline 1191.977 & $100-\mathrm{yr}$ & 33.91 & 256.91 & 258.69 & 1.61 & 23.13 & 36.74 & 1.77 \\
\hline 1191.977 & $500-\mathrm{yr}$ & 46.94 & 256.91 & 258.86 & 1.81 & 31.38 & 53.55 & 1.95 \\
\hline 1155.309 & $2-y r$ & 1.66 & 257.11 & 257.48 & 0.99 & 1.68 & 6.46 & 0.37 \\
\hline 1155.309 & $100-\mathrm{yr}$ & 33.91 & 257.11 & 258.53 & 1.77 & 24.17 & 44.67 & 1.42 \\
\hline 1155.309 & $500-\mathrm{yr}$ & 46.94 & 257.11 & 258.76 & 1.62 & 34.94 & 48.66 & 1.65 \\
\hline 1124.025 & $2-y r$ & 1.66 & 255.94 & 256.33 & 1.42 & 1.17 & 5.94 & 0.39 \\
\hline 1124.025 & $100-y r$ & 33.91 & 255.94 & 257.44 & 3.11 & 10.89 & 11.08 & 1.5 \\
\hline 1124.025 & $500-\mathrm{yr}$ & 46.94 & 255.94 & 257.71 & 3.36 & 13.97 & 13.21 & 1.77 \\
\hline
\end{tabular}




\begin{tabular}{|c|c|c|c|c|c|c|c|c|}
\hline River Sta & Profile & $\begin{array}{c}\text { Q Total } \\
\left(\mathrm{m}^{3} / \mathrm{s}\right)\end{array}$ & $\begin{array}{c}\text { Min Ch } \\
\text { El } \\
(\mathbf{m})\end{array}$ & $\begin{array}{l}\text { W.S. } \\
\text { Elev } \\
(\mathbf{m})\end{array}$ & $\begin{array}{c}\text { Vel } \\
\text { Chnl } \\
(\mathbf{m} / \mathbf{s})\end{array}$ & $\begin{array}{l}\text { Flow } \\
\text { Area } \\
\left(\mathbf{m}^{2}\right) \\
\end{array}$ & $\begin{array}{c}\text { Top } \\
\text { Width } \\
(\mathbf{m}) \\
\end{array}$ & $\begin{array}{c}\text { Max Chl } \\
\text { Dpth } \\
(\mathbf{m})\end{array}$ \\
\hline 1083.982 & $2-y r$ & 1.66 & 255 & 255.56 & 0.62 & 2.68 & 7.07 & 0.56 \\
\hline 1083.982 & $100-\mathrm{yr}$ & 33.91 & 255 & 257.03 & 1.88 & 18.05 & 13.52 & 2.03 \\
\hline 1083.982 & $500-y r$ & 46.94 & 255 & 257.28 & 2.15 & 23.1 & 30.66 & 2.28 \\
\hline 1018.257 & $2-y r$ & 1.66 & 254.8 & 255.23 & 1.07 & 1.55 & 6.14 & 0.43 \\
\hline 1018.257 & $100-\mathrm{yr}$ & 33.91 & 254.8 & 256.45 & 2.59 & 13.54 & 19.72 & 1.65 \\
\hline 1018.257 & $500-\mathrm{yr}$ & 46.94 & 254.8 & 256.67 & 2.83 & 18.69 & 27.62 & 1.87 \\
\hline 959.582 & $2-y r$ & 1.66 & 254.42 & 254.86 & 0.73 & 2.28 & 7.7 & 0.44 \\
\hline 959.582 & $100-\mathrm{yr}$ & 33.91 & 254.42 & 256.23 & 1.76 & 21.52 & 31.23 & 1.81 \\
\hline 959.582 & $500-\mathrm{yr}$ & 46.94 & 254.42 & 256.53 & 1.75 & 32.66 & 44.16 & 2.11 \\
\hline 917.744 & $2-y r$ & 1.66 & 253.94 & 254.43 & 0.89 & 1.86 & 7.03 & 0.49 \\
\hline 917.744 & $100-\mathrm{yr}$ & 33.91 & 253.94 & 255.81 & 2.07 & 16.47 & 17.57 & 1.87 \\
\hline 917.744 & $500-\mathrm{yr}$ & 46.94 & 253.94 & 256.13 & 2.15 & 23.57 & 26.63 & 2.19 \\
\hline 885.843 & $2-y r$ & 1.66 & 253.61 & 254.06 & 1.23 & 1.35 & 5.1 & 0.45 \\
\hline 885.843 & $100-y r$ & 33.91 & 253.61 & 255.21 & 3.13 & 10.85 & 10.98 & 1.6 \\
\hline 885.843 & $500-y r$ & 46.94 & 253.61 & 255.47 & 3.39 & 13.84 & 11.85 & 1.86 \\
\hline 831.018 & $2-y r$ & 1.66 & 252.63 & 252.94 & 1.46 & 1.14 & 5.32 & 0.31 \\
\hline 831.018 & $100-\mathrm{yr}$ & 33.91 & 252.63 & 254.11 & 3.11 & 10.91 & 11.25 & 1.48 \\
\hline 831.018 & $500-\mathrm{yr}$ & 46.94 & 252.63 & 254.37 & 3.35 & 14.03 & 12.47 & 1.74 \\
\hline 794.448 & $2-y r$ & 1.66 & 251.86 & 252.27 & 0.84 & 1.99 & 6.63 & 0.41 \\
\hline 794.448 & $100-\mathrm{yr}$ & 33.91 & 251.86 & 253.64 & 2.02 & 16.77 & 14.66 & 1.78 \\
\hline 794.448 & $500-\mathrm{yr}$ & 46.94 & 251.86 & 253.93 & 2.22 & 21.28 & 16.17 & 2.07 \\
\hline 753.27 & $2-y r$ & 1.66 & 251.5 & 251.97 & 1 & 1.66 & 5.87 & 0.47 \\
\hline 753.27 & $100-\mathrm{yr}$ & 33.91 & 251.5 & 253.05 & 2.88 & 11.79 & 12.03 & 1.55 \\
\hline 753.27 & $500-\mathrm{yr}$ & 46.94 & 251.5 & 253.24 & 3.29 & 14.25 & 12.9 & 1.74 \\
\hline 720.714 & $2-y r$ & 1.66 & 251.09 & 251.44 & 1.4 & 1.19 & 6.03 & 0.35 \\
\hline 720.714 & $100-\mathrm{yr}$ & 33.91 & 251.09 & 252.5 & 2.98 & 11.38 & 12.77 & 1.41 \\
\hline 720.714 & $500-\mathrm{yr}$ & 46.94 & 251.09 & 252.74 & 3.23 & 14.6 & 14.29 & 1.65 \\
\hline 673.556 & $2-y r$ & 1.66 & 250.52 & 251.02 & 0.36 & 4.67 & 14.02 & 0.5 \\
\hline 673.556 & $100-\mathrm{yr}$ & 33.91 & 250.52 & 252.26 & 1 & 33.92 & 33.96 & 1.74 \\
\hline 673.556 & $500-\mathrm{yr}$ & 46.94 & 250.52 & 252.5 & 1.11 & 42.79 & 38.29 & 1.98 \\
\hline
\end{tabular}




\begin{tabular}{|c|c|c|c|c|c|c|c|c|}
\hline River Sta & Profile & $\begin{array}{c}\text { Q Total } \\
\left(\mathbf{m}^{3} / \mathbf{s}\right)\end{array}$ & $\begin{array}{c}\text { Min Ch } \\
\text { El } \\
(\mathbf{m})\end{array}$ & $\begin{array}{l}\text { W.S. } \\
\text { Elev } \\
(\mathbf{m})\end{array}$ & $\begin{array}{l}\text { Vel } \\
\text { Chnl } \\
(\mathbf{m} / \mathbf{s})\end{array}$ & $\begin{array}{l}\text { Flow } \\
\text { Area } \\
\left(\mathbf{m}^{2}\right)\end{array}$ & $\begin{array}{c}\text { Top } \\
\text { Width } \\
\text { (m) }\end{array}$ & $\begin{array}{c}\text { Max Chl } \\
\text { Dpth } \\
\text { (m) }\end{array}$ \\
\hline 625.562 & $2-y r$ & 1.66 & 250.47 & 250.91 & 0.75 & 2.2 & 8.69 & 0.44 \\
\hline 625.562 & $100-\mathrm{yr}$ & 33.91 & 250.47 & 251.84 & 2.35 & 14.43 & 18.37 & 1.37 \\
\hline 625.562 & $500-\mathrm{yr}$ & 46.94 & 250.47 & 251.96 & 2.82 & 16.74 & 20.45 & 1.49 \\
\hline 582.64 & $2-y r$ & 1.66 & 250.01 & 250.37 & 1.35 & 1.23 & 6.82 & 0.36 \\
\hline 582.64 & $100-\mathrm{yr}$ & 33.91 & 250.01 & 251.27 & 2.49 & 15.03 & 27.65 & 1.26 \\
\hline 582.64 & $500-\mathrm{yr}$ & 46.94 & 250.01 & 251.45 & 2.65 & 20.35 & 32.2 & 1.44 \\
\hline 543.04 & $2-y r$ & 1.66 & 249.4 & 249.72 & 0.85 & 1.95 & 10.45 & 0.32 \\
\hline 543.04 & $100-\mathrm{yr}$ & 33.91 & 249.4 & 250.52 & 2.19 & 16.11 & 23.78 & 1.12 \\
\hline 543.04 & $500-\mathrm{yr}$ & 46.94 & 249.4 & 250.66 & 2.56 & 19.36 & 25.65 & 1.26 \\
\hline 496.118 & $2-y r$ & 1.66 & 249.1 & 249.51 & 0.49 & 3.41 & 15 & 0.41 \\
\hline 496.118 & $100-\mathrm{yr}$ & 33.91 & 249.1 & 250.29 & 1.43 & 24.14 & 37.2 & 1.19 \\
\hline 496.118 & $500-\mathrm{yr}$ & 46.94 & 249.1 & 250.43 & 1.65 & 29.48 & 40.88 & 1.33 \\
\hline 428.594 & $2-y r$ & 1.66 & 248.79 & 249.01 & 1.1 & 1.51 & 12.29 & 0.22 \\
\hline 428.594 & $100-\mathrm{yr}$ & 33.91 & 248.79 & 249.61 & 2.2 & 16.95 & 38.5 & 0.82 \\
\hline 428.594 & $500-\mathrm{yr}$ & 46.94 & 248.79 & 249.73 & 2.39 & 21.86 & 42.82 & 0.94 \\
\hline 389.142 & $2-y r$ & 1.66 & 248.21 & 248.48 & 0.7 & 2.98 & 25.95 & 0.27 \\
\hline 389.142 & $100-\mathrm{yr}$ & 33.91 & 248.21 & 249.3 & 1.16 & 34.46 & 48.02 & 1.09 \\
\hline 389.142 & $500-\mathrm{yr}$ & 46.94 & 248.21 & 249.49 & 1.27 & 43.98 & 51.97 & 1.28 \\
\hline 343.978 & $2-y r$ & 1.66 & 247.75 & 248.08 & 0.52 & 3.17 & 14.02 & 0.33 \\
\hline 343.978 & $100-\mathrm{yr}$ & 33.91 & 247.75 & 249.02 & 1.43 & 26.11 & 35.29 & 1.27 \\
\hline 343.978 & $500-\mathrm{yr}$ & 46.94 & 247.75 & 249.2 & 1.61 & 32.92 & 39.28 & 1.45 \\
\hline 318.111 & $2-\mathrm{yr}$ & 1.66 & 247.65 & 247.97 & 0.64 & 2.57 & 12.17 & 0.32 \\
\hline 318.111 & $100-\mathrm{yr}$ & 33.91 & 247.65 & 248.89 & 1.58 & 23.23 & 32.28 & 1.24 \\
\hline 318.111 & $500-\mathrm{yr}$ & 46.94 & 247.65 & 249.07 & 1.78 & 29.15 & 35.88 & 1.42 \\
\hline 284.899 & $2-\mathrm{yr}$ & 1.66 & 247.49 & 247.85 & 0.51 & 3.27 & 13.91 & 0.36 \\
\hline 284.899 & $100-\mathrm{yr}$ & 33.91 & 247.49 & 248.79 & 1.33 & 26.72 & 35.57 & 1.3 \\
\hline 284.899 & $500-\mathrm{yr}$ & 46.94 & 247.49 & 248.97 & 1.51 & 33.17 & 39.06 & 1.48 \\
\hline 244.681 & $2-y r$ & 1.66 & 247.05 & 247.31 & 1.23 & 1.35 & 8.79 & 0.26 \\
\hline 244.681 & $100-\mathrm{yr}$ & 33.91 & 247.05 & 248.11 & 2.41 & 14.05 & 24.09 & 1.06 \\
\hline 244.681 & $500-\mathrm{yr}$ & 46.94 & 247.05 & 248.29 & 2.5 & 18.75 & 28.27 & 1.24 \\
\hline
\end{tabular}




\begin{tabular}{|c|c|c|c|c|c|c|c|c|}
\hline River Sta & Profile & $\begin{array}{c}\text { Q Total } \\
\left(\mathbf{m}^{3} / \mathbf{s}\right)\end{array}$ & $\begin{array}{c}\text { Min Ch } \\
\text { El } \\
(\mathrm{m})\end{array}$ & $\begin{array}{l}\text { W.S. } \\
\text { Elev } \\
(\mathrm{m})\end{array}$ & $\begin{array}{c}\text { Vel } \\
\text { Chnl } \\
(\mathrm{m} / \mathrm{s})\end{array}$ & $\begin{array}{l}\text { Flow } \\
\text { Area } \\
\left(\mathbf{m}^{2}\right)\end{array}$ & $\begin{array}{c}\text { Top } \\
\text { Width } \\
\text { (m) }\end{array}$ & $\begin{array}{c}\text { Max Chl } \\
\text { Dpth } \\
\text { (m) }\end{array}$ \\
\hline 214.499 & $2-y r$ & 1.66 & 246.61 & 247.1 & 0.37 & 4.46 & 14.49 & 0.49 \\
\hline 214.499 & $100-\mathrm{yr}$ & 33.91 & 246.61 & 248.12 & 1.2 & 30.58 & 37.19 & 1.51 \\
\hline 214.499 & $500-\mathrm{yr}$ & 46.94 & 246.61 & 248.32 & 1.35 & 38.45 & 41.67 & 1.71 \\
\hline 214.498 & $2-y r$ & 1.66 & 246.61 & 246.9 & 0.86 & 1.94 & 10.63 & 0.29 \\
\hline 214.498 & $100-\mathrm{yr}$ & 33.91 & 246.61 & 247.64 & 2.2 & 15.5 & 26.37 & 1.03 \\
\hline 214.498 & $500-\mathrm{yr}$ & 46.94 & 246.61 & 247.77 & 2.52 & 18.96 & 29.11 & 1.16 \\
\hline 147.881 & $2-y r$ & 1.66 & 245.82 & 246.12 & 0.88 & 1.88 & 10.22 & 0.3 \\
\hline 147.881 & $100-\mathrm{yr}$ & 33.91 & 245.82 & 247.03 & 1.75 & 19.5 & 28.82 & 1.21 \\
\hline 147.881 & $500-y r$ & 46.94 & 245.82 & 247.21 & 1.92 & 25.17 & 33.21 & 1.39 \\
\hline 79.942 & $2-y r$ & 1.66 & 245.12 & 245.48 & 0.82 & 2.03 & 8.8 & 0.36 \\
\hline 79.942 & $100-\mathrm{yr}$ & 33.91 & 245.12 & 246.61 & 1.68 & 20.25 & 24.15 & 1.49 \\
\hline 79.942 & $500-\mathrm{yr}$ & 46.94 & 245.12 & 246.84 & 1.81 & 26.42 & 27.75 & 1.72 \\
\hline 53.415 & $2-y r$ & 1.66 & 244.76 & 245.06 & 1.4 & 1.18 & 6.01 & 0.3 \\
\hline 53.415 & $100-\mathrm{yr}$ & 33.91 & 244.76 & 246.08 & 2.81 & 12.08 & 15.01 & 1.33 \\
\hline 53.415 & $500-y r$ & 46.94 & 244.76 & 246.3 & 3.04 & 15.54 & 17.53 & 1.54 \\
\hline 13.63 & $2-y r$ & 1.66 & 243.93 & 244.25 & 1.09 & 1.52 & 6.89 & 0.32 \\
\hline 13.63 & $100-\mathrm{yr}$ & 33.91 & 243.93 & 245.27 & 2.59 & 13.34 & 21.18 & 1.34 \\
\hline 13.63 & $500-\mathrm{yr}$ & 46.94 & 243.93 & 245.49 & 2.64 & 19.49 & 33.92 & 1.56 \\
\hline
\end{tabular}

Table 22: Steady GLD (During mining) cross-sectional properties

\begin{tabular}{|c|c|c|c|c|c|c|c|c|}
\hline River Sta & Profile & $\begin{array}{c}\text { Q Total } \\
\left(\mathbf{m}^{3} / \mathbf{s}\right)\end{array}$ & $\begin{array}{c}\text { Min Ch } \\
\text { El } \\
(\mathbf{m})\end{array}$ & $\begin{array}{l}\text { W.S. } \\
\text { Elev } \\
(\mathbf{m}) \\
\end{array}$ & $\begin{array}{c}\text { Vel } \\
\text { Chnl } \\
(\mathbf{m} / \mathbf{s}) \\
\end{array}$ & $\begin{array}{l}\text { Flow } \\
\text { Area } \\
\left(\mathbf{m}^{2}\right) \\
\end{array}$ & $\begin{array}{c}\text { Top } \\
\text { Width } \\
\text { (m) } \\
\end{array}$ & $\begin{array}{c}\text { Max Chl } \\
\text { Dpth } \\
(\mathbf{m}) \\
\end{array}$ \\
\hline 2097.011 & $2-y r$ & 20.27 & 264.87 & 266.31 & 1.72 & 11.8 & 12.87 & 1.44 \\
\hline 2097.011 & $100-\mathrm{yr}$ & 63.28 & 264.87 & 267.26 & 2.3 & 29.07 & 30.6 & 2.39 \\
\hline 2097.011 & $500-y r$ & 92.16 & 264.87 & 267.72 & 2.32 & 47.28 & 46.27 & 2.85 \\
\hline 2052.742 & $2-y r$ & 20.27 & 264.51 & 265.66 & 2.69 & 7.54 & 10.36 & 1.15 \\
\hline 2052.742 & $100-\mathrm{yr}$ & 63.28 & 264.51 & 266.49 & 3.51 & 18.05 & 14.79 & 1.98 \\
\hline 2052.742 & $500-y r$ & 92.16 & 264.51 & 266.87 & 3.88 & 24.23 & 18.13 & 2.36 \\
\hline 2009.086 & $2-\mathrm{yr}$ & 20.27 & 263.84 & 264.85 & 1.88 & 10.81 & 16.27 & 1.01 \\
\hline
\end{tabular}




\begin{tabular}{|c|c|c|c|c|c|c|c|c|}
\hline River Sta & Profile & $\begin{array}{c}\text { Q Total } \\
\left(\mathbf{m}^{3} / \mathbf{s}\right)\end{array}$ & $\begin{array}{c}\text { Min Ch } \\
\text { El } \\
(\mathbf{m})\end{array}$ & $\begin{array}{l}\text { W.S. } \\
\text { Elev } \\
(\mathbf{m})\end{array}$ & $\begin{array}{c}\text { Vel } \\
\text { Chnl } \\
(\mathbf{m} / \mathbf{s})\end{array}$ & $\begin{array}{l}\text { Flow } \\
\text { Area } \\
\left(\mathbf{m}^{2}\right) \\
\end{array}$ & $\begin{array}{c}\text { Top } \\
\text { Width } \\
(\mathbf{m})\end{array}$ & $\begin{array}{c}\text { Max Chl } \\
\text { Dpth } \\
(\mathbf{m})\end{array}$ \\
\hline 2009.086 & $100-\mathrm{yr}$ & 63.28 & 263.84 & 265.39 & 3.08 & 20.78 & 21.06 & 1.55 \\
\hline 2009.086 & $500-\mathrm{yr}$ & 92.16 & 263.84 & 265.67 & 3.5 & 27.1 & 23.67 & 1.83 \\
\hline 1964.49 & $2-\mathrm{yr}$ & 20.27 & 263.35 & 264.17 & 2.23 & 9.09 & 17.85 & 0.82 \\
\hline 1964.49 & $100-\mathrm{yr}$ & 63.28 & 263.35 & 264.74 & 2.87 & 22.1 & 27.24 & 1.39 \\
\hline 1964.49 & $500-\mathrm{yr}$ & 92.16 & 263.35 & 265 & 3.16 & 29.69 & 31.62 & 1.65 \\
\hline 1925.761 & $2-\mathrm{yr}$ & 20.27 & 263.04 & 263.9 & 1.12 & 19.84 & 41.9 & 0.86 \\
\hline 1925.761 & $100-\mathrm{yr}$ & 63.28 & 263.04 & 264.5 & 1.46 & 55.91 & 85.14 & 1.46 \\
\hline 1925.761 & $500-\mathrm{yr}$ & 92.16 & 263.04 & 264.74 & 1.56 & 78.31 & 98.37 & 1.7 \\
\hline 1874.546 & $2-\mathrm{yr}$ & 20.27 & 262.4 & 263.48 & 1.31 & 15.7 & 26.69 & 1.08 \\
\hline 1874.546 & $100-\mathrm{yr}$ & 63.28 & 262.4 & 263.93 & 2.26 & 31.08 & 44.79 & 1.53 \\
\hline 1874.546 & $500-\mathrm{yr}$ & 92.16 & 262.4 & 264.29 & 2.22 & 49.33 & 55.79 & 1.89 \\
\hline 1828.159 & $2-\mathrm{yr}$ & 20.27 & 262.13 & 262.93 & 2.05 & 9.9 & 23.62 & 0.8 \\
\hline 1828.159 & $100-y r$ & 63.28 & 262.13 & 263.65 & 2.07 & 33.85 & 43.52 & 1.52 \\
\hline 1828.159 & $500-\mathrm{yr}$ & 92.16 & 262.13 & 264.17 & 1.82 & 63.97 & 83.24 & 2.04 \\
\hline 1788.723 & $2-y r$ & 20.27 & 261.54 & 262.81 & 0.9 & 23.34 & 34.08 & 1.27 \\
\hline 1788.723 & $100-y r$ & 63.28 & 261.54 & 263.65 & 1.21 & 58.75 & 49.2 & 2.11 \\
\hline 1788.723 & $500-\mathrm{yr}$ & 92.16 & 261.54 & 264.16 & 1.25 & 86.33 & 58.94 & 2.62 \\
\hline 1742.556 & $2-y r$ & 20.27 & 261.5 & 262.69 & 1.04 & 19.66 & 29.11 & 1.19 \\
\hline 1742.556 & $100-y r$ & 63.28 & 261.5 & 263.57 & 1.34 & 52.69 & 47.31 & 2.07 \\
\hline 1742.556 & $500-\mathrm{yr}$ & 92.16 & 261.5 & 264.1 & 1.36 & 87.25 & 99.3 & 2.6 \\
\hline 1695.655 & $2-y r$ & 20.27 & 261.28 & 262.29 & 2.02 & 10.04 & 17.55 & 1.01 \\
\hline 1695.655 & $100-\mathrm{yr}$ & 63.28 & 261.28 & 263.51 & 1.29 & 63.66 & 66.38 & 2.23 \\
\hline 1695.655 & $500-\mathrm{yr}$ & 92.16 & 261.28 & 264.08 & 1.12 & 104.02 & 75.83 & 2.8 \\
\hline 1651.05 & $2-y r$ & 20.27 & 260.78 & 262.27 & 0.91 & 22.33 & 22.68 & 1.49 \\
\hline 1651.05 & $100-\mathrm{yr}$ & 63.28 & 260.78 & 263.46 & 1.16 & 55.87 & 34.13 & 2.68 \\
\hline 1651.05 & $500-\mathrm{yr}$ & 92.16 & 260.78 & 264.01 & 1.28 & 76.4 & 40.61 & 3.23 \\
\hline 1617.21 & $2-y r$ & 20.27 & 260.56 & 262.21 & 1.03 & 19.73 & 19.66 & 1.64 \\
\hline 1617.21 & $100-\mathrm{yr}$ & 63.28 & 260.56 & 263.4 & 1.32 & 47.84 & 27.26 & 2.84 \\
\hline 1617.21 & $500-\mathrm{yr}$ & 92.16 & 260.56 & 263.95 & 1.45 & 63.71 & 30.77 & 3.39 \\
\hline 1577.381 & $2-\mathrm{yr}$ & 20.27 & 260.48 & 262.22 & 0.43 & 46.79 & 36.8 & 1.74 \\
\hline
\end{tabular}




\begin{tabular}{|c|c|c|c|c|c|c|c|c|}
\hline River Sta & Profile & $\begin{array}{c}\text { Q Total } \\
\left(\mathbf{m}^{3} / \mathbf{s}\right)\end{array}$ & $\begin{array}{c}\text { Min Ch } \\
\text { El } \\
(\mathbf{m})\end{array}$ & $\begin{array}{l}\text { W.S. } \\
\text { Elev } \\
(\mathbf{m})\end{array}$ & $\begin{array}{c}\text { Vel } \\
\text { Chnl } \\
(\mathbf{m} / \mathbf{s})\end{array}$ & $\begin{array}{l}\text { Flow } \\
\text { Area } \\
\left(\mathbf{m}^{2}\right) \\
\end{array}$ & $\begin{array}{c}\text { Top } \\
\text { Width } \\
(\mathbf{m})\end{array}$ & $\begin{array}{c}\text { Max Chl } \\
\text { Dpth } \\
(\mathbf{m})\end{array}$ \\
\hline 1577.381 & $100-\mathrm{yr}$ & 63.28 & 260.48 & 263.43 & 0.63 & 114.06 & 72.2 & 2.95 \\
\hline 1577.381 & $500-y r$ & 92.16 & 260.48 & 263.99 & 0.68 & 156.59 & 79.93 & 3.51 \\
\hline 1542.946 & $2-y r$ & 20.27 & 260.49 & 261.95 & 2.16 & 9.4 & 9.97 & 1.46 \\
\hline 1542.946 & $100-\mathrm{yr}$ & 63.28 & 260.49 & 262.86 & 3.17 & 19.94 & 12.88 & 2.37 \\
\hline 1542.946 & $500-\mathrm{yr}$ & 92.16 & 260.49 & 263.19 & 3.79 & 24.5 & 18.37 & 2.7 \\
\hline 1504.079 & $2-y r$ & 20.27 & 260.31 & 261.61 & 2.1 & 9.67 & 11.13 & 1.3 \\
\hline 1504.079 & $100-\mathrm{yr}$ & 63.28 & 260.31 & 262.29 & 3.49 & 18.21 & 14.1 & 1.98 \\
\hline 1504.079 & $500-\mathrm{yr}$ & 92.16 & 260.31 & 262.72 & 3.77 & 25.23 & 22.18 & 2.41 \\
\hline 1467.659 & $2-y r$ & 20.27 & 260.12 & 261.38 & 1.74 & 11.67 & 14.59 & 1.26 \\
\hline 1467.659 & $100-y r$ & 63.28 & 260.12 & 261.96 & 2.96 & 21.91 & 24.62 & 1.84 \\
\hline 1467.659 & $500-\mathrm{yr}$ & 92.16 & 260.12 & 262.28 & 3.2 & 32.58 & 36.37 & 2.16 \\
\hline 1425.307 & $2-\mathrm{yr}$ & 20.27 & 259.66 & 260.84 & 2.31 & 8.79 & 13.27 & 1.18 \\
\hline 1425.307 & $100-y r$ & 63.28 & 259.66 & 261.56 & 2.92 & 25.61 & 33.46 & 1.9 \\
\hline 1425.307 & $500-\mathrm{yr}$ & 92.16 & 259.66 & 261.81 & 3.28 & 33.96 & 35.63 & 2.15 \\
\hline 1392.843 & $2-y r$ & 20.27 & 259.14 & 260.29 & 2.49 & 8.13 & 11.28 & 1.15 \\
\hline 1392.843 & $100-y r$ & 63.28 & 259.14 & 261.18 & 2.7 & 27 & 36.63 & 2.04 \\
\hline 1392.843 & $500-\mathrm{yr}$ & 92.16 & 259.14 & 261.56 & 2.65 & 41.39 & 39.48 & 2.42 \\
\hline 1358.799 & $2-y r$ & 20.27 & 258.63 & 259.82 & 2.33 & 8.69 & 11.58 & 1.19 \\
\hline 1358.799 & $100-y r$ & 63.28 & 258.63 & 260.53 & 3.42 & 18.74 & 17.45 & 1.9 \\
\hline 1358.799 & $500-\mathrm{yr}$ & 92.16 & 258.63 & 261 & 3.44 & 30.07 & 37.78 & 2.37 \\
\hline 1329.439 & $2-y r$ & 20.27 & 258.21 & 259.28 & 2.62 & 7.74 & 11.23 & 1.07 \\
\hline 1329.439 & $100-y r$ & 63.28 & 258.21 & 260.25 & 3.01 & 21.69 & 18.26 & 2.04 \\
\hline 1329.439 & $500-\mathrm{yr}$ & 92.16 & 258.21 & 260.48 & 3.74 & 26.11 & 24.02 & 2.27 \\
\hline 1302.462 & $2-y r$ & 20.27 & 257.76 & 259.34 & 1.11 & 18.25 & 17.3 & 1.58 \\
\hline 1302.462 & $100-\mathrm{yr}$ & 63.28 & 257.76 & 260.39 & 1.56 & 43.91 & 51.25 & 2.63 \\
\hline 1302.462 & $500-\mathrm{yr}$ & 92.16 & 257.76 & 260.74 & 1.75 & 62.58 & 57.57 & 2.98 \\
\hline 1264.23 & $2-y r$ & 20.27 & 257.59 & 258.81 & 2.36 & 8.6 & 10.96 & 1.22 \\
\hline 1264.23 & $100-\mathrm{yr}$ & 63.28 & 257.59 & 259.55 & 3.49 & 18.13 & 14.73 & 1.96 \\
\hline 1264.23 & $500-\mathrm{yr}$ & 92.16 & 257.59 & 260.09 & 3.21 & 32.75 & 39.39 & 2.5 \\
\hline 1230.005 & $2-y r$ & 20.27 & 257.24 & 258.68 & 1.57 & 12.93 & 13.87 & 1.44 \\
\hline
\end{tabular}




\begin{tabular}{|c|c|c|c|c|c|c|c|c|}
\hline River Sta & Profile & $\begin{array}{c}\text { Q Total } \\
\left(\mathbf{m}^{3} / \mathbf{s}\right)\end{array}$ & $\begin{array}{c}\text { Min Ch } \\
\text { El } \\
(\mathbf{m})\end{array}$ & $\begin{array}{l}\text { W.S. } \\
\text { Elev } \\
(\mathbf{m})\end{array}$ & $\begin{array}{c}\text { Vel } \\
\text { Chnl } \\
(\mathbf{m} / \mathbf{s})\end{array}$ & $\begin{array}{l}\text { Flow } \\
\text { Area } \\
\left(\mathbf{m}^{2}\right) \\
\end{array}$ & $\begin{array}{c}\text { Top } \\
\text { Width } \\
(\mathbf{m})\end{array}$ & $\begin{array}{c}\text { Max Chl } \\
\text { Dpth } \\
(\mathbf{m})\end{array}$ \\
\hline 1230.005 & $100-\mathrm{yr}$ & 63.28 & 257.24 & 259.29 & 2.82 & 23.01 & 26.42 & 2.05 \\
\hline 1230.005 & $500-\mathrm{yr}$ & 92.16 & 257.24 & 259.65 & 2.98 & 37.93 & 52.5 & 2.41 \\
\hline 1191.977 & $2-\mathrm{yr}$ & 20.27 & 256.91 & 258.47 & 1.21 & 16.81 & 22.17 & 1.56 \\
\hline 1191.977 & $100-\mathrm{yr}$ & 63.28 & 256.91 & 258.99 & 2.08 & 38.67 & 61.16 & 2.08 \\
\hline 1191.977 & $500-\mathrm{yr}$ & 92.16 & 256.91 & 259.24 & 2.22 & 54.87 & 67.66 & 2.33 \\
\hline 1155.309 & $2-\mathrm{yr}$ & 20.27 & 257.11 & 258.24 & 1.88 & 13.04 & 29.88 & 1.13 \\
\hline 1155.309 & $100-\mathrm{yr}$ & 63.28 & 257.11 & 258.85 & 1.89 & 39.69 & 50.42 & 1.74 \\
\hline 1155.309 & $500-\mathrm{yr}$ & 92.16 & 257.11 & 259.1 & 1.98 & 52.95 & 54.96 & 1.99 \\
\hline 1124.025 & $2-\mathrm{yr}$ & 20.27 & 255.94 & 257.11 & 2.74 & 7.4 & 9.69 & 1.17 \\
\hline 1124.025 & $100-\mathrm{yr}$ & 63.28 & 255.94 & 258.17 & 2.74 & 28.4 & 41.98 & 2.23 \\
\hline 1124.025 & $500-\mathrm{yr}$ & 92.16 & 255.94 & 258.39 & 3.03 & 37.98 & 44.23 & 2.45 \\
\hline 1083.982 & $2-y r$ & 20.27 & 255 & 256.62 & 1.58 & 12.85 & 11.8 & 1.62 \\
\hline 1083.982 & $100-y r$ & 63.28 & 255 & 257.49 & 2.42 & 29.72 & 34.73 & 2.49 \\
\hline 1083.982 & $500-\mathrm{yr}$ & 92.16 & 255 & 257.7 & 2.9 & 37.57 & 38.28 & 2.7 \\
\hline 1018.257 & $2-\mathrm{yr}$ & 20.27 & 254.8 & 256.12 & 2.18 & 9.29 & 10.52 & 1.32 \\
\hline 1018.257 & $100-y r$ & 63.28 & 254.8 & 256.89 & 2.97 & 25.44 & 33.71 & 2.09 \\
\hline 1018.257 & $500-\mathrm{yr}$ & 92.16 & 254.8 & 257.21 & 3.06 & 37.33 & 40.5 & 2.41 \\
\hline 959.582 & $2-y r$ & 20.27 & 254.42 & 255.83 & 1.61 & 12.63 & 13.06 & 1.41 \\
\hline 959.582 & $100-\mathrm{yr}$ & 63.28 & 254.42 & 256.81 & 1.71 & 46.38 & 51.1 & 2.39 \\
\hline 959.582 & $500-\mathrm{yr}$ & 92.16 & 254.42 & 257.17 & 1.77 & 65.68 & 55.9 & 2.75 \\
\hline 917.744 & $2-y r$ & 20.27 & 253.94 & 255.42 & 1.78 & 11.41 & 11.98 & 1.48 \\
\hline 917.744 & $100-\mathrm{yr}$ & 63.28 & 253.94 & 256.48 & 2.11 & 34.16 & 33.74 & 2.54 \\
\hline 917.744 & $500-\mathrm{yr}$ & 92.16 & 253.94 & 256.87 & 2.21 & 48.49 & 39.66 & 2.93 \\
\hline 885.843 & $2-y r$ & 20.27 & 253.61 & 254.87 & 2.75 & 7.36 & 9.69 & 1.26 \\
\hline 885.843 & $100-\mathrm{yr}$ & 63.28 & 253.61 & 255.81 & 3.49 & 18.48 & 18.38 & 2.2 \\
\hline 885.843 & $500-\mathrm{yr}$ & 92.16 & 253.61 & 256.29 & 3.47 & 29.7 & 27.89 & 2.68 \\
\hline 831.018 & $2-y r$ & 20.27 & 252.63 & 253.77 & 2.75 & 7.36 & 9.67 & 1.14 \\
\hline 831.018 & $100-\mathrm{yr}$ & 63.28 & 252.63 & 254.64 & 3.59 & 17.64 & 13.58 & 2.01 \\
\hline 831.018 & $500-\mathrm{yr}$ & 92.16 & 252.63 & 255.04 & 4 & 23.29 & 15.06 & 2.41 \\
\hline 794.448 & $2-y r$ & 20.27 & 251.86 & 253.25 & 1.77 & 11.48 & 12.75 & 1.39 \\
\hline
\end{tabular}




\begin{tabular}{|c|c|c|c|c|c|c|c|c|}
\hline River Sta & Profile & $\begin{array}{c}\text { Q Total } \\
\left(\mathbf{m}^{3} / \mathbf{s}\right)\end{array}$ & $\begin{array}{c}\text { Min Ch } \\
\text { El } \\
(\mathbf{m})\end{array}$ & $\begin{array}{l}\text { W.S. } \\
\text { Elev } \\
(\mathbf{m})\end{array}$ & $\begin{array}{c}\text { Vel } \\
\text { Chnl } \\
(\mathbf{m} / \mathbf{s})\end{array}$ & $\begin{array}{c}\text { Flow } \\
\text { Area } \\
\left(\mathbf{m}^{2}\right) \\
\end{array}$ & $\begin{array}{c}\text { Top } \\
\text { Width } \\
\text { (m) }\end{array}$ & $\begin{array}{c}\text { Max Chl } \\
\text { Dpth } \\
(\mathbf{m})\end{array}$ \\
\hline 794.448 & $100-\mathrm{yr}$ & 63.28 & 251.86 & 254.22 & 2.46 & 26.28 & 17.68 & 2.36 \\
\hline 794.448 & $500-\mathrm{yr}$ & 92.16 & 251.86 & 254.65 & 2.8 & 34.27 & 19.86 & 2.79 \\
\hline 753.27 & $2-y r$ & 20.27 & 251.5 & 252.76 & 2.37 & 8.57 & 10.79 & 1.26 \\
\hline 753.27 & $100-y r$ & 63.28 & 251.5 & 253.51 & 3.54 & 17.88 & 14.08 & 2.01 \\
\hline 753.27 & $500-y r$ & 92.16 & 251.5 & 253.91 & 3.9 & 23.85 & 16.39 & 2.41 \\
\hline 720.714 & $2-y r$ & 20.27 & 251.09 & 252.19 & 2.64 & 7.69 & 11.02 & 1.1 \\
\hline 720.714 & $100-\mathrm{yr}$ & 63.28 & 251.09 & 252.99 & 3.49 & 18.49 & 16.05 & 1.9 \\
\hline 720.714 & $500-\mathrm{yr}$ & 92.16 & 251.09 & 253.37 & 3.86 & 25.02 & 18.61 & 2.28 \\
\hline 673.556 & $2-y r$ & 20.27 & 250.52 & 251.93 & 0.85 & 23.78 & 28.23 & 1.41 \\
\hline 673.556 & $100-\mathrm{yr}$ & 63.28 & 250.52 & 252.76 & 1.22 & 53.19 & 43.29 & 2.24 \\
\hline 673.556 & $500-y r$ & 92.16 & 250.52 & 253.11 & 1.4 & 69.84 & 50.96 & 2.59 \\
\hline 625.562 & $2-y r$ & 20.27 & 250.47 & 251.64 & 1.83 & 11.09 & 15.88 & 1.17 \\
\hline 625.562 & $100-\mathrm{yr}$ & 63.28 & 250.47 & 252.15 & 3.1 & 21.04 & 24.02 & 1.68 \\
\hline 625.562 & $500-\mathrm{yr}$ & 92.16 & 250.47 & 252.47 & 3.33 & 29.79 & 29.93 & 2 \\
\hline 582.64 & $2-y r$ & 20.27 & 250.01 & 251.01 & 2.3 & 9.03 & 19.02 & 1 \\
\hline 582.64 & $100-\mathrm{yr}$ & 63.28 & 250.01 & 251.61 & 2.87 & 25.78 & 35.28 & 1.6 \\
\hline 582.64 & $500-\mathrm{yr}$ & 92.16 & 250.01 & 251.84 & 3.17 & 34.49 & 39.44 & 1.83 \\
\hline 543.04 & $2-y r$ & 20.27 & 249.4 & 250.34 & 1.72 & 12 & 21.15 & 0.94 \\
\hline 543.04 & $100-y r$ & 63.28 & 249.4 & 250.78 & 2.97 & 22.82 & 27.56 & 1.39 \\
\hline 543.04 & $500-\mathrm{yr}$ & 92.16 & 249.4 & 251.05 & 3.3 & 30.76 & 31.6 & 1.65 \\
\hline 496.118 & $2-y r$ & 20.27 & 249.1 & 250.11 & 1.14 & 17.81 & 32.23 & 1.01 \\
\hline 496.118 & $100-\mathrm{yr}$ & 63.28 & 249.1 & 250.57 & 1.88 & 35.44 & 44.61 & 1.47 \\
\hline 496.118 & $500-\mathrm{yr}$ & 92.16 & 249.1 & 250.77 & 2.23 & 44.73 & 49.94 & 1.67 \\
\hline 428.594 & $2-y r$ & 20.27 & 248.79 & 249.44 & 1.95 & 11.09 & 31.79 & 0.65 \\
\hline 428.594 & $100-\mathrm{yr}$ & 63.28 & 248.79 & 249.85 & 2.58 & 27.59 & 47.18 & 1.06 \\
\hline 428.594 & $500-\mathrm{yr}$ & 92.16 & 248.79 & 250.04 & 2.86 & 36.91 & 53.35 & 1.25 \\
\hline 389.142 & $2-\mathrm{yr}$ & 20.27 & 248.21 & 249.05 & 1.02 & 23.2 & 42.55 & 0.84 \\
\hline 389.142 & $100-\mathrm{yr}$ & 63.28 & 248.21 & 249.69 & 1.39 & 54.8 & 55.95 & 1.48 \\
\hline 389.142 & $500-y r$ & 92.16 & 248.21 & 249.99 & 1.57 & 72.14 & 61.64 & 1.78 \\
\hline 343.978 & $2-\mathrm{yr}$ & 20.27 & 247.75 & 248.77 & 1.19 & 18.04 & 29.77 & 1.02 \\
\hline
\end{tabular}




\begin{tabular}{|c|c|c|c|c|c|c|c|c|}
\hline River Sta & Profile & $\begin{array}{c}\text { Q Total } \\
\left(\mathbf{m}^{3} / \mathbf{s}\right)\end{array}$ & $\begin{array}{c}\text { Min Ch } \\
\text { El } \\
(\mathbf{m})\end{array}$ & $\begin{array}{l}\text { W.S. } \\
\text { Elev } \\
(\mathbf{m})\end{array}$ & $\begin{array}{c}\text { Vel } \\
\text { Chnl } \\
(\mathbf{m} / \mathbf{s})\end{array}$ & $\begin{array}{l}\text { Flow } \\
\text { Area } \\
\left(\mathbf{m}^{2}\right) \\
\end{array}$ & $\begin{array}{c}\text { Top } \\
\text { Width } \\
\text { (m) }\end{array}$ & $\begin{array}{c}\text { Max Chl } \\
\text { Dpth } \\
\text { (m) }\end{array}$ \\
\hline 343.978 & $100-\mathrm{yr}$ & 63.28 & 247.75 & 249.39 & 1.79 & 40.62 & 43.16 & 1.64 \\
\hline 343.978 & $500-y r$ & 92.16 & 247.75 & 249.66 & 2.05 & 53.26 & 49.13 & 1.91 \\
\hline 318.111 & $2-y r$ & 20.27 & 247.65 & 248.66 & 1.32 & 16.08 & 27.45 & 1.01 \\
\hline 318.111 & $100-y r$ & 63.28 & 247.65 & 249.24 & 1.99 & 35.69 & 39.25 & 1.59 \\
\hline 318.111 & $500-y r$ & 92.16 & 247.65 & 249.5 & 2.28 & 46.5 & 44.6 & 1.85 \\
\hline 284.899 & $2-y r$ & 20.27 & 247.49 & 248.55 & 1.1 & 18.71 & 29.99 & 1.06 \\
\hline 284.899 & $100-\mathrm{yr}$ & 63.28 & 247.49 & 249.14 & 1.72 & 40.03 & 42.56 & 1.65 \\
\hline 284.899 & $500-y r$ & 92.16 & 247.49 & 249.39 & 2 & 51.45 & 47.76 & 1.9 \\
\hline 244.681 & $2-y r$ & 20.27 & 247.05 & 247.89 & 2.2 & 9.21 & 19.09 & 0.84 \\
\hline 244.681 & $100-\mathrm{yr}$ & 63.28 & 247.05 & 248.5 & 2.55 & 25.02 & 33.14 & 1.45 \\
\hline 244.681 & $500-y r$ & 92.16 & 247.05 & 248.78 & 2.71 & 35.26 & 40.28 & 1.73 \\
\hline 214.499 & $2-y r$ & 20.27 & 246.61 & 247.86 & 0.97 & 21.75 & 31.05 & 1.25 \\
\hline 214.499 & $100-y r$ & 63.28 & 246.61 & 248.52 & 1.52 & 47.47 & 46.26 & 1.91 \\
\hline 214.499 & $500-y r$ & 92.16 & 246.61 & 248.81 & 1.75 & 61.65 & 52.44 & 2.2 \\
\hline 214.498 & $2-y r$ & 20.27 & 246.61 & 247.46 & 1.83 & 11.1 & 22.3 & 0.85 \\
\hline 214.498 & $100-y r$ & 63.28 & 246.61 & 247.92 & 2.76 & 23.64 & 32.36 & 1.31 \\
\hline 214.498 & $500-y r$ & 92.16 & 246.61 & 248.16 & 3.03 & 32.26 & 38.19 & 1.55 \\
\hline 147.881 & $2-y r$ & 20.27 & 245.82 & 246.78 & 1.56 & 13 & 23.58 & 0.96 \\
\hline 147.881 & $100-y r$ & 63.28 & 245.82 & 247.42 & 2.06 & 32.61 & 38.61 & 1.6 \\
\hline 147.881 & $500-y r$ & 92.16 & 245.82 & 247.73 & 2.23 & 45.97 & 47.95 & 1.91 \\
\hline 79.942 & $2-y r$ & 20.27 & 245.12 & 246.28 & 1.53 & 13.23 & 19.34 & 1.16 \\
\hline 79.942 & $100-y r$ & 63.28 & 245.12 & 247.1 & 1.93 & 34.28 & 34.19 & 1.98 \\
\hline 79.942 & $500-y r$ & 92.16 & 245.12 & 247.49 & 2.04 & 53.79 & 67.61 & 2.37 \\
\hline 53.415 & $2-y r$ & 20.27 & 244.76 & 245.79 & 2.51 & 8.07 & 12.56 & 1.03 \\
\hline 53.415 & $100-y r$ & 63.28 & 244.76 & 246.52 & 3.29 & 19.77 & 20.18 & 1.76 \\
\hline 53.415 & $500-y r$ & 92.16 & 244.76 & 246.9 & 3.5 & 29.03 & 29.46 & 2.14 \\
\hline 13.63 & $2-y r$ & 20.27 & 243.93 & 244.98 & 2.28 & 8.9 & 13.23 & 1.05 \\
\hline 13.63 & $100-y r$ & 63.28 & 243.93 & 245.7 & 2.71 & 27.66 & 43.62 & 1.77 \\
\hline 13.63 & $500-y r$ & 92.16 & 243.93 & 245.91 & 3.02 & 37.67 & 49.7 & 1.98 \\
\hline
\end{tabular}


Table 23: Steady GLD (Post Mining) cross-sectional properties

\begin{tabular}{|c|c|c|c|c|c|c|c|c|}
\hline River Sta & Profile & $\begin{array}{c}\text { Q Total } \\
\left(\mathbf{m}^{3} / \mathbf{s}\right)\end{array}$ & $\begin{array}{c}\text { Min Ch } \\
\text { El } \\
(\mathbf{m}) \\
\end{array}$ & $\begin{array}{l}\text { W.S. } \\
\text { Elev } \\
(\mathbf{m})\end{array}$ & $\begin{array}{c}\text { Vel } \\
\text { Chnl } \\
(\mathrm{m} / \mathrm{s}) \\
\end{array}$ & $\begin{array}{l}\text { Flow } \\
\text { Area } \\
\left(\mathbf{m}^{2}\right) \\
\end{array}$ & $\begin{array}{c}\text { Top } \\
\text { Width } \\
(\mathbf{m}) \\
\end{array}$ & $\begin{array}{c}\text { Max Chl } \\
\text { Dpth } \\
(\mathrm{m}) \\
\end{array}$ \\
\hline 2097.011 & $2-y r$ & 3.81 & 264.87 & 265.55 & 1 & 3.81 & 8.31 & 0.68 \\
\hline 2097.011 & $100-\mathrm{yr}$ & 23.35 & 264.87 & 266.4 & 1.79 & 13.06 & 13.51 & 1.53 \\
\hline 2097.011 & $500-\mathrm{yr}$ & 37 & 264.87 & 266.76 & 2.03 & 18.25 & 15.77 & 1.89 \\
\hline 2052.742 & $2-y r$ & 3.81 & 264.51 & 265.04 & 1.78 & 2.14 & 6.78 & 0.53 \\
\hline 2052.742 & $100-\mathrm{yr}$ & 23.35 & 264.51 & 265.74 & 2.79 & 8.38 & 10.77 & 1.23 \\
\hline 2052.742 & $500-\mathrm{yr}$ & 37 & 264.51 & 266.05 & 3.1 & 11.94 & 12.4 & 1.54 \\
\hline 2009.086 & $2-y r$ & 3.81 & 263.84 & 264.31 & 1.12 & 3.41 & 10.76 & 0.47 \\
\hline 2009.086 & $100-\mathrm{yr}$ & 23.35 & 263.84 & 264.92 & 1.97 & 11.86 & 16.86 & 1.08 \\
\hline 2009.086 & $500-\mathrm{yr}$ & 37 & 263.84 & 265.12 & 2.38 & 15.55 & 18.74 & 1.28 \\
\hline 1964.49 & $2-y r$ & 3.81 & 263.35 & 263.74 & 1.3 & 2.94 & 11.33 & 0.39 \\
\hline 1964.49 & $100-\mathrm{yr}$ & 23.35 & 263.35 & 264.22 & 2.31 & 10.09 & 18.77 & 0.87 \\
\hline 1964.49 & $500-\mathrm{yr}$ & 37 & 263.35 & 264.44 & 2.55 & 14.5 & 22.26 & 1.09 \\
\hline 1925.761 & $2-y r$ & 3.81 & 263.04 & 263.42 & 0.75 & 5.06 & 20.57 & 0.38 \\
\hline 1925.761 & $100-\mathrm{yr}$ & 23.35 & 263.04 & 263.96 & 1.16 & 22.32 & 44.05 & 0.92 \\
\hline 1925.761 & $500-\mathrm{yr}$ & 37 & 263.04 & 264.18 & 1.31 & 33.11 & 56.11 & 1.14 \\
\hline 1874.546 & $2-y r$ & 3.81 & 262.4 & 262.97 & 0.74 & 5.15 & 15.22 & 0.57 \\
\hline 1874.546 & $100-\mathrm{yr}$ & 23.35 & 262.4 & 263.53 & 1.38 & 17.2 & 28.2 & 1.13 \\
\hline 1874.546 & $500-\mathrm{yr}$ & 37 & 262.4 & 263.72 & 1.69 & 23.13 & 34.36 & 1.32 \\
\hline 1828.159 & $2-y r$ & 3.81 & 262.13 & 262.52 & 1.47 & 2.59 & 11.89 & 0.39 \\
\hline 1828.159 & $100-\mathrm{yr}$ & 23.35 & 262.13 & 262.97 & 2.13 & 10.95 & 24.69 & 0.84 \\
\hline 1828.159 & $500-\mathrm{yr}$ & 37 & 262.13 & 263.15 & 2.38 & 15.86 & 29.34 & 1.02 \\
\hline 1788.723 & $2-y r$ & 3.81 & 261.54 & 262.21 & 0.54 & 7.01 & 19.75 & 0.67 \\
\hline 1788.723 & $100-\mathrm{yr}$ & 23.35 & 261.54 & 262.88 & 0.95 & 25.76 & 35.6 & 1.34 \\
\hline 1788.723 & $500-\mathrm{yr}$ & 37 & 261.54 & 263.17 & 1.08 & 37.03 & 41.14 & 1.63 \\
\hline 1742.556 & $2-y r$ & 3.81 & 261.5 & 262.11 & 0.63 & 6.05 & 16.94 & 0.61 \\
\hline 1742.556 & $100-\mathrm{yr}$ & 23.35 & 261.5 & 262.76 & 1.1 & 21.68 & 30.35 & 1.26 \\
\hline 1742.556 & $500-\mathrm{yr}$ & 37 & 261.5 & 263.06 & 1.23 & 31.77 & 36.44 & 1.56 \\
\hline 1695.655 & $2-y r$ & 3.81 & 261.28 & 261.71 & 1.61 & 2.37 & 9.18 & 0.43 \\
\hline 1695.655 & $100-\mathrm{yr}$ & 23.35 & 261.28 & 262.41 & 1.95 & 12.18 & 20.18 & 1.13 \\
\hline 1695.655 & $500-\mathrm{yr}$ & 37 & 261.28 & 262.84 & 1.78 & 24.36 & 48.78 & 1.56 \\
\hline
\end{tabular}




\begin{tabular}{|c|c|c|c|c|c|c|c|c|}
\hline River Sta & Profile & $\begin{array}{c}\text { Q Total } \\
\left(\mathbf{m}^{3} / \mathbf{s}\right)\end{array}$ & $\begin{array}{c}\text { Min Ch } \\
\text { El } \\
\text { (m) }\end{array}$ & $\begin{array}{c}\text { W.S. } \\
\text { Elev } \\
(\mathbf{m})\end{array}$ & $\begin{array}{c}\text { Vel } \\
\text { Chnl } \\
(\mathrm{m} / \mathrm{s}) \\
\end{array}$ & $\begin{array}{l}\text { Flow } \\
\text { Area } \\
\left(\mathbf{m}^{2}\right) \\
\end{array}$ & $\begin{array}{c}\text { Top } \\
\text { Width } \\
(\mathbf{m}) \\
\end{array}$ & $\begin{array}{c}\text { Max Chl } \\
\text { Dpth } \\
(\mathbf{m}) \\
\end{array}$ \\
\hline 1651.05 & $2-y r$ & 3.81 & 260.78 & 261.38 & 0.68 & 5.61 & 14.46 & 0.6 \\
\hline 1651.05 & $100-\mathrm{yr}$ & 23.35 & 260.78 & 262.38 & 0.94 & 24.95 & 23.67 & 1.6 \\
\hline 1651.05 & $500-\mathrm{yr}$ & 37 & 260.78 & 262.81 & 1.03 & 35.93 & 27.62 & 2.03 \\
\hline 1617.21 & $2-y r$ & 3.81 & 260.56 & 261.29 & 0.72 & 5.3 & 11.6 & 0.73 \\
\hline 1617.21 & $100-\mathrm{yr}$ & 23.35 & 260.56 & 262.32 & 1.06 & 22.01 & 20.48 & 1.76 \\
\hline 1617.21 & $500-\mathrm{yr}$ & 37 & 260.56 & 262.75 & 1.18 & 31.38 & 23.3 & 2.19 \\
\hline 1577.381 & $2-y r$ & 3.81 & 260.48 & 261.29 & 0.22 & 17.22 & 27.35 & 0.81 \\
\hline 1577.381 & $100-y r$ & 23.35 & 260.48 & 262.33 & 0.46 & 51.23 & 39.76 & 1.85 \\
\hline 1577.381 & $500-\mathrm{yr}$ & 37 & 260.48 & 262.77 & 0.54 & 72.16 & 55.82 & 2.29 \\
\hline 1542.946 & $2-y r$ & 3.81 & 260.49 & 261.2 & 1.16 & 3.28 & 6.48 & 0.71 \\
\hline 1542.946 & $100-\mathrm{yr}$ & 23.35 & 260.49 & 262.03 & 2.27 & 10.31 & 10.29 & 1.54 \\
\hline 1542.946 & $500-\mathrm{yr}$ & 37 & 260.49 & 262.36 & 2.68 & 13.83 & 11.34 & 1.87 \\
\hline 1504.079 & $2-y r$ & 3.81 & 260.31 & 260.94 & 1.18 & 3.22 & 8.07 & 0.63 \\
\hline 1504.079 & $100-\mathrm{yr}$ & 23.35 & 260.31 & 261.69 & 2.21 & 10.57 & 11.49 & 1.38 \\
\hline 1504.079 & $500-y r$ & 37 & 260.31 & 261.97 & 2.66 & 13.92 & 12.76 & 1.66 \\
\hline 1467.659 & $2-y r$ & 3.81 & 260.12 & 260.69 & 1.08 & 3.53 & 9.08 & 0.57 \\
\hline 1467.659 & $100-\mathrm{yr}$ & 23.35 & 260.12 & 261.46 & 1.82 & 12.86 & 15.32 & 1.34 \\
\hline 1467.659 & $500-\mathrm{yr}$ & 37 & 260.12 & 261.75 & 2.1 & 17.61 & 18.34 & 1.63 \\
\hline 1425.307 & $2-y r$ & 3.81 & 259.66 & 260.24 & 1.44 & 2.65 & 7.58 & 0.58 \\
\hline 1425.307 & $100-y r$ & 23.35 & 259.66 & 260.92 & 2.36 & 9.89 & 14.05 & 1.26 \\
\hline 1425.307 & $500-\mathrm{yr}$ & 37 & 259.66 & 261.16 & 2.77 & 13.9 & 21.16 & 1.5 \\
\hline 1392.843 & $2-y r$ & 3.81 & 259.14 & 259.69 & 1.61 & 2.36 & 7.47 & 0.54 \\
\hline 1392.843 & $100-\mathrm{yr}$ & 23.35 & 259.14 & 260.37 & 2.59 & 9.02 & 11.75 & 1.23 \\
\hline 1392.843 & $500-\mathrm{yr}$ & 37 & 259.14 & 260.73 & 2.67 & 13.86 & 15.33 & 1.59 \\
\hline 1358.799 & $2-y r$ & 3.81 & 258.63 & 259.23 & 1.31 & 2.9 & 7.99 & 0.6 \\
\hline 1358.799 & $100-\mathrm{yr}$ & 23.35 & 258.63 & 259.9 & 2.44 & 9.58 & 12.04 & 1.27 \\
\hline 1358.799 & $500-\mathrm{yr}$ & 37 & 258.63 & 260.12 & 2.97 & 12.46 & 13.63 & 1.49 \\
\hline 1329.439 & $2-y r$ & 3.81 & 258.21 & 258.7 & 1.73 & 2.21 & 7.42 & 0.49 \\
\hline 1329.439 & $100-\mathrm{yr}$ & 23.35 & 258.21 & 259.36 & 2.71 & 8.61 & 11.68 & 1.15 \\
\hline 1329.439 & $500-\mathrm{yr}$ & 37 & 258.21 & 259.74 & 2.75 & 13.46 & 13.93 & 1.53 \\
\hline
\end{tabular}




\begin{tabular}{|c|c|c|c|c|c|c|c|c|}
\hline River Sta & Profile & $\begin{array}{c}\text { Q Total } \\
\left(\mathbf{m}^{3} / \mathbf{s}\right)\end{array}$ & $\begin{array}{c}\text { Min Ch } \\
\text { El } \\
\text { (m) }\end{array}$ & $\begin{array}{c}\text { W.S. } \\
\text { Elev } \\
(\mathbf{m})\end{array}$ & $\begin{array}{c}\text { Vel } \\
\text { Chnl } \\
(\mathrm{m} / \mathrm{s}) \\
\end{array}$ & $\begin{array}{l}\text { Flow } \\
\text { Area } \\
\left(\mathbf{m}^{2}\right) \\
\end{array}$ & $\begin{array}{c}\text { Top } \\
\text { Width } \\
(\mathbf{m}) \\
\end{array}$ & $\begin{array}{c}\text { Max Chl } \\
\text { Dpth } \\
(\mathbf{m}) \\
\end{array}$ \\
\hline 1302.462 & $2-y r$ & 3.81 & 257.76 & 258.52 & 0.61 & 6.28 & 12.04 & 0.76 \\
\hline 1302.462 & $100-\mathrm{yr}$ & 23.35 & 257.76 & 259.44 & 1.16 & 20.1 & 17.99 & 1.68 \\
\hline 1302.462 & $500-\mathrm{yr}$ & 37 & 257.76 & 259.83 & 1.34 & 27.71 & 20.76 & 2.07 \\
\hline 1264.23 & $2-y r$ & 3.81 & 257.59 & 258.11 & 1.73 & 2.2 & 6.91 & 0.52 \\
\hline 1264.23 & $100-\mathrm{yr}$ & 23.35 & 257.59 & 258.89 & 2.46 & 9.49 & 11.35 & 1.3 \\
\hline 1264.23 & $500-\mathrm{yr}$ & 37 & 257.59 & 259.17 & 2.88 & 12.86 & 12.73 & 1.58 \\
\hline 1230.005 & $2-y r$ & 3.81 & 257.24 & 257.91 & 0.93 & 4.1 & 9.08 & 0.67 \\
\hline 1230.005 & $100-\mathrm{yr}$ & 23.35 & 257.24 & 258.75 & 1.66 & 14.03 & 14.28 & 1.51 \\
\hline 1230.005 & $500-\mathrm{yr}$ & 37 & 257.24 & 259.01 & 2.06 & 17.94 & 15.67 & 1.77 \\
\hline 1191.977 & $2-y r$ & 3.81 & 256.91 & 257.81 & 0.53 & 7.25 & 12 & 0.9 \\
\hline 1191.977 & $100-\mathrm{yr}$ & 23.35 & 256.91 & 258.53 & 1.32 & 18.18 & 26.43 & 1.62 \\
\hline 1191.977 & $500-\mathrm{yr}$ & 37 & 256.91 & 258.73 & 1.68 & 24.74 & 39.66 & 1.82 \\
\hline 1155.309 & $2-y r$ & 3.81 & 257.11 & 257.65 & 1.32 & 2.9 & 7.73 & 0.54 \\
\hline 1155.309 & $100-\mathrm{yr}$ & 23.35 & 257.11 & 258.31 & 1.86 & 15.21 & 31.83 & 1.2 \\
\hline 1155.309 & $500-y r$ & 37 & 257.11 & 258.58 & 1.73 & 26.72 & 45.86 & 1.47 \\
\hline 1124.025 & $2-y r$ & 3.81 & 255.94 & 256.48 & 1.76 & 2.16 & 7.03 & 0.54 \\
\hline 1124.025 & $100-\mathrm{yr}$ & 23.35 & 255.94 & 257.19 & 2.84 & 8.23 & 10.04 & 1.25 \\
\hline 1124.025 & $500-\mathrm{yr}$ & 37 & 255.94 & 257.51 & 3.18 & 11.64 & 11.36 & 1.57 \\
\hline 1083.982 & $2-y r$ & 3.81 & 255 & 255.79 & 0.85 & 4.48 & 8.32 & 0.79 \\
\hline 1083.982 & $100-y r$ & 23.35 & 255 & 256.73 & 1.65 & 14.11 & 12.24 & 1.73 \\
\hline 1083.982 & $500-\mathrm{yr}$ & 37 & 255 & 257.1 & 1.95 & 19.01 & 13.81 & 2.1 \\
\hline 1018.257 & $2-y r$ & 3.81 & 254.8 & 255.42 & 1.32 & 2.89 & 7.7 & 0.62 \\
\hline 1018.257 & $100-\mathrm{yr}$ & 23.35 & 254.8 & 256.21 & 2.27 & 10.27 & 10.87 & 1.41 \\
\hline 1018.257 & $500-\mathrm{yr}$ & 37 & 254.8 & 256.51 & 2.67 & 14.69 & 22.02 & 1.71 \\
\hline 959.582 & $2-y r$ & 3.81 & 254.42 & 255.06 & 0.97 & 3.94 & 9.21 & 0.64 \\
\hline 959.582 & $100-\mathrm{yr}$ & 23.35 & 254.42 & 255.93 & 1.67 & 14 & 16.05 & 1.51 \\
\hline 959.582 & $500-y r$ & 37 & 254.42 & 256.31 & 1.76 & 24.1 & 34.64 & 1.89 \\
\hline 917.744 & $2-y r$ & 3.81 & 253.94 & 254.63 & 1.12 & 3.42 & 8.23 & 0.69 \\
\hline 917.744 & $100-\mathrm{yr}$ & 23.35 & 253.94 & 255.52 & 1.85 & 12.6 & 12.41 & 1.58 \\
\hline 917.744 & $500-\mathrm{yr}$ & 37 & 253.94 & 255.89 & 2.11 & 17.92 & 19.64 & 1.95 \\
\hline
\end{tabular}




\begin{tabular}{|c|c|c|c|c|c|c|c|c|}
\hline River Sta & Profile & $\begin{array}{c}\text { Q Total } \\
\left(\mathrm{m}^{3} / \mathbf{s}\right)\end{array}$ & $\begin{array}{c}\text { Min Ch } \\
\text { El } \\
(\mathbf{m}) \\
\end{array}$ & $\begin{array}{c}\text { W.S. } \\
\text { Elev } \\
(\mathbf{m})\end{array}$ & $\begin{array}{c}\text { Vel } \\
\text { Chnl } \\
(\mathbf{m} / \mathbf{s}) \\
\end{array}$ & $\begin{array}{l}\text { Flow } \\
\text { Area } \\
\left(\mathbf{m}^{2}\right) \\
\end{array}$ & $\begin{array}{c}\text { Top } \\
\text { Width } \\
(\mathbf{m}) \\
\end{array}$ & $\begin{array}{c}\text { Max Chl } \\
\text { Dpth } \\
(\mathbf{m}) \\
\end{array}$ \\
\hline 885.843 & $2-y r$ & 3.81 & 253.61 & 254.22 & 1.67 & 2.27 & 6.02 & 0.61 \\
\hline 885.843 & $100-\mathrm{yr}$ & 23.35 & 253.61 & 254.95 & 2.85 & 8.18 & 10.02 & 1.34 \\
\hline 885.843 & $500-\mathrm{yr}$ & 37 & 253.61 & 255.27 & 3.2 & 11.58 & 11.2 & 1.66 \\
\hline 831.018 & $2-y r$ & 3.81 & 252.63 & 253.11 & 1.82 & 2.1 & 6.27 & 0.48 \\
\hline 831.018 & $100-\mathrm{yr}$ & 23.35 & 252.63 & 253.85 & 2.85 & 8.2 & 10.07 & 1.22 \\
\hline 831.018 & $500-\mathrm{yr}$ & 37 & 252.63 & 254.17 & 3.17 & 11.69 & 11.56 & 1.54 \\
\hline 794.448 & $2-y r$ & 3.81 & 251.86 & 252.49 & 1.07 & 3.56 & 8.01 & 0.63 \\
\hline 794.448 & $100-\mathrm{yr}$ & 23.35 & 251.86 & 253.35 & 1.83 & 12.74 & 13.28 & 1.49 \\
\hline 794.448 & $500-\mathrm{yr}$ & 37 & 251.86 & 253.71 & 2.08 & 17.84 & 15.03 & 1.85 \\
\hline 753.27 & $2-y r$ & 3.81 & 251.5 & 252.15 & 1.32 & 2.9 & 7.48 & 0.65 \\
\hline 753.27 & $100-\mathrm{yr}$ & 23.35 & 251.5 & 252.84 & 2.5 & 9.36 & 11.11 & 1.34 \\
\hline 753.27 & $500-\mathrm{yr}$ & 37 & 251.5 & 253.1 & 2.98 & 12.43 & 12.26 & 1.6 \\
\hline 720.714 & $2-y r$ & 3.81 & 251.09 & 251.6 & 1.74 & 2.19 & 7.25 & 0.51 \\
\hline 720.714 & $100-\mathrm{yr}$ & 23.35 & 251.09 & 252.27 & 2.73 & 8.57 & 11.47 & 1.18 \\
\hline 720.714 & $500-\mathrm{yr}$ & 37 & 251.09 & 252.56 & 3.05 & 12.15 & 13.06 & 1.47 \\
\hline 673.556 & $2-y r$ & 3.81 & 250.52 & 251.22 & 0.49 & 7.8 & 16.96 & 0.7 \\
\hline 673.556 & $100-\mathrm{yr}$ & 23.35 & 250.52 & 252.01 & 0.89 & 26.22 & 29.79 & 1.49 \\
\hline 673.556 & $500-\mathrm{yr}$ & 37 & 250.52 & 252.32 & 1.03 & 36.01 & 34.99 & 1.8 \\
\hline 625.562 & $2-y r$ & 3.81 & 250.47 & 251.07 & 1.01 & 3.78 & 10.21 & 0.6 \\
\hline 625.562 & $100-y r$ & 23.35 & 250.47 & 251.7 & 1.94 & 12.02 & 16.6 & 1.23 \\
\hline 625.562 & $500-\mathrm{yr}$ & 37 & 250.47 & 251.87 & 2.47 & 14.97 & 18.79 & 1.4 \\
\hline 582.64 & $2-y r$ & 3.81 & 250.01 & 250.51 & 1.62 & 2.36 & 9.13 & 0.5 \\
\hline 582.64 & $100-\mathrm{yr}$ & 23.35 & 250.01 & 251.08 & 2.35 & 10.33 & 21.21 & 1.07 \\
\hline 582.64 & $500-\mathrm{yr}$ & 37 & 250.01 & 251.32 & 2.54 & 16.33 & 29.16 & 1.31 \\
\hline 543.04 & $2-y r$ & 3.81 & 249.4 & 249.87 & 1.01 & 3.77 & 13.56 & 0.47 \\
\hline 543.04 & $100-\mathrm{yr}$ & 23.35 & 249.4 & 250.39 & 1.84 & 13.01 & 21.85 & 0.99 \\
\hline 543.04 & $500-\mathrm{yr}$ & 37 & 249.4 & 250.56 & 2.29 & 16.93 & 24.27 & 1.16 \\
\hline 496.118 & $2-\mathrm{yr}$ & 3.81 & 249.1 & 249.66 & 0.63 & 6.03 & 19.61 & 0.56 \\
\hline 496.118 & $100-\mathrm{yr}$ & 23.35 & 249.1 & 250.16 & 1.21 & 19.35 & 33.56 & 1.06 \\
\hline 496.118 & $500-\mathrm{yr}$ & 37 & 249.1 & 250.33 & 1.49 & 25.37 & 38.01 & 1.23 \\
\hline
\end{tabular}




\begin{tabular}{|c|c|c|c|c|c|c|c|c|}
\hline River Sta & Profile & $\begin{array}{c}\text { Q Total } \\
\left(\mathrm{m}^{3} / \mathbf{s}\right)\end{array}$ & $\begin{array}{c}\text { Min Ch } \\
\text { El } \\
\text { (m) }\end{array}$ & $\begin{array}{l}\text { W.S. } \\
\text { Elev } \\
(\mathrm{m})\end{array}$ & $\begin{array}{c}\text { Vel } \\
\text { Chnl } \\
(\mathbf{m} / \mathbf{s}) \\
\end{array}$ & $\begin{array}{l}\text { Flow } \\
\text { Area } \\
\left(\mathbf{m}^{2}\right) \\
\end{array}$ & $\begin{array}{c}\text { Top } \\
\text { Width } \\
(\mathbf{m}) \\
\end{array}$ & $\begin{array}{c}\text { Max Chl } \\
\text { Dpth } \\
(\mathbf{m})\end{array}$ \\
\hline 428.594 & $2-y r$ & 3.81 & 248.79 & 249.11 & 1.32 & 2.88 & 16.71 & 0.32 \\
\hline 428.594 & $100-\mathrm{yr}$ & 23.35 & 248.79 & 249.48 & 2.01 & 12.49 & 33.51 & 0.69 \\
\hline 428.594 & $500-y r$ & 37 & 248.79 & 249.64 & 2.23 & 18.3 & 39.71 & 0.85 \\
\hline 389.142 & $2-y r$ & 3.81 & 248.21 & 248.59 & 0.75 & 6.04 & 29.73 & 0.38 \\
\hline 389.142 & $100-y r$ & 23.35 & 248.21 & 249.12 & 1.05 & 25.93 & 44 & 0.91 \\
\hline 389.142 & $500-y r$ & 37 & 248.21 & 249.35 & 1.19 & 36.8 & 49.04 & 1.14 \\
\hline 343.978 & $2-y r$ & 3.81 & 247.75 & 248.24 & 0.68 & 5.64 & 17.11 & 0.49 \\
\hline 343.978 & $100-\mathrm{yr}$ & 23.35 & 247.75 & 248.83 & 1.25 & 19.95 & 31.29 & 1.08 \\
\hline 343.978 & $500-y r$ & 37 & 247.75 & 249.07 & 1.47 & 27.79 & 36.31 & 1.32 \\
\hline 318.111 & $2-y r$ & 3.81 & 247.65 & 248.13 & 0.79 & 4.8 & 15.58 & 0.48 \\
\hline 318.111 & $100-\mathrm{yr}$ & 23.35 & 247.65 & 248.72 & 1.39 & 17.77 & 28.76 & 1.07 \\
\hline 318.111 & $500-y r$ & 37 & 247.65 & 248.94 & 1.63 & 24.71 & 33.19 & 1.29 \\
\hline 284.899 & $2-y r$ & 3.81 & 247.49 & 248.01 & 0.66 & 5.78 & 17.36 & 0.52 \\
\hline 284.899 & $100-\mathrm{yr}$ & 23.35 & 247.49 & 248.61 & 1.16 & 20.57 & 31.42 & 1.12 \\
\hline 284.899 & $500-\mathrm{yr}$ & 37 & 247.49 & 248.84 & 1.37 & 28.36 & 36.45 & 1.35 \\
\hline 244.681 & $2-y r$ & 3.81 & 247.05 & 247.43 & 1.53 & 2.49 & 10.72 & 0.38 \\
\hline 244.681 & $100-\mathrm{yr}$ & 23.35 & 247.05 & 247.95 & 2.24 & 10.42 & 20.39 & 0.9 \\
\hline 244.681 & $500-y r$ & 37 & 247.05 & 248.16 & 2.45 & 15.1 & 25.12 & 1.11 \\
\hline 214.499 & $2-y r$ & 3.81 & 246.61 & 247.28 & 0.51 & 7.5 & 18.48 & 0.67 \\
\hline 214.499 & $100-\mathrm{yr}$ & 23.35 & 246.61 & 247.92 & 1.03 & 23.84 & 32.5 & 1.31 \\
\hline 214.499 & $500-y r$ & 37 & 246.61 & 248.17 & 1.24 & 32.52 & 38.34 & 1.56 \\
\hline 214.498 & $2-y r$ & 3.81 & 246.61 & 247.02 & 1.12 & 3.4 & 12.97 & 0.41 \\
\hline 214.498 & $100-y r$ & 23.35 & 246.61 & 247.51 & 1.9 & 12.31 & 23.45 & 0.9 \\
\hline 214.498 & $500-y r$ & 37 & 246.61 & 247.67 & 2.28 & 16.36 & 27.1 & 1.06 \\
\hline 147.881 & $2-y r$ & 3.81 & 245.82 & 246.26 & 1.09 & 3.49 & 13.08 & 0.44 \\
\hline 147.881 & $100-y r$ & 23.35 & 245.82 & 246.85 & 1.6 & 14.62 & 24.98 & 1.03 \\
\hline 147.881 & $500-\mathrm{yr}$ & 37 & 245.82 & 247.07 & 1.79 & 20.81 & 29.94 & 1.25 \\
\hline 79.942 & $2-y r$ & 3.81 & 245.12 & 245.65 & 1.04 & 3.65 & 10.89 & 0.53 \\
\hline 79.942 & $100-\mathrm{yr}$ & 23.35 & 245.12 & 246.37 & 1.57 & 14.9 & 20.63 & 1.25 \\
\hline 79.942 & $500-y r$ & 37 & 245.12 & 246.67 & 1.71 & 21.76 & 25.06 & 1.55 \\
\hline
\end{tabular}




\begin{tabular}{|c|c|c|c|c|c|c|c|c|}
\hline River Sta & Profile & $\begin{array}{c}\text { Q Total } \\
\left(\mathrm{m}^{3} / \mathrm{s}\right)\end{array}$ & $\begin{array}{c}\text { Min Ch } \\
\text { El } \\
(\mathbf{m}) \\
\end{array}$ & $\begin{array}{c}\text { W.S. } \\
\text { Elev } \\
(\mathbf{m})\end{array}$ & $\begin{array}{c}\text { Vel } \\
\text { Chnl } \\
(\mathrm{m} / \mathrm{s}) \\
\end{array}$ & $\begin{array}{l}\text { Flow } \\
\text { Area } \\
\left(\mathbf{m}^{2}\right) \\
\end{array}$ & $\begin{array}{c}\text { Top } \\
\text { Width } \\
(\mathbf{m}) \\
\end{array}$ & $\begin{array}{c}\text { Max Chl } \\
\text { Dpth } \\
(\mathbf{m}) \\
\end{array}$ \\
\hline 53.415 & $2-y r$ & 3.81 & 244.76 & 245.21 & 1.72 & 2.22 & 7.48 & 0.45 \\
\hline 53.415 & $100-\mathrm{yr}$ & 23.35 & 244.76 & 245.87 & 2.59 & 9.01 & 13.18 & 1.11 \\
\hline 53.415 & $500-\mathrm{yr}$ & 37 & 244.76 & 246.14 & 2.86 & 12.92 & 15.68 & 1.38 \\
\hline 13.63 & $2-y r$ & 3.81 & 243.93 & 244.41 & 1.41 & 2.7 & 8.33 & 0.48 \\
\hline 13.63 & $100-\mathrm{yr}$ & 23.35 & 243.93 & 245.05 & 2.36 & 9.88 & 13.92 & 1.12 \\
\hline 13.63 & $500-\mathrm{yr}$ & 37 & 243.93 & 245.32 & 2.63 & 14.54 & 24.2 & 1.39 \\
\hline
\end{tabular}

Table 24: Unsteady Pre-mining cross-sectional properties

\begin{tabular}{|c|c|c|c|c|c|c|c|c|c|c|}
\hline $\begin{array}{l}\text { River } \\
\text { Sta }\end{array}$ & Profile & Plan & Time at Max & $\begin{array}{c}\mathbf{Q} \\
\text { Total } \\
\left(\mathbf{m}^{3} / \mathbf{s}\right) \\
\end{array}$ & $\begin{array}{c}\text { Min } \\
\text { Ch El } \\
(\mathbf{m}) \\
\end{array}$ & $\begin{array}{l}\text { W.S. } \\
\text { Elev } \\
(\mathbf{m})\end{array}$ & $\begin{array}{c}\text { Vel } \\
\text { Chnl } \\
(\mathbf{m} / \mathbf{s}) \\
\end{array}$ & $\begin{array}{l}\text { Flow } \\
\text { Area } \\
\left(\mathbf{m}^{2}\right) \\
\end{array}$ & $\begin{array}{c}\text { Top } \\
\text { Width } \\
(\mathbf{m})\end{array}$ & $\begin{array}{c}\text { Max Chl } \\
\text { Dpth } \\
\text { (m) }\end{array}$ \\
\hline 2097.011 & Max WS & $2-\mathrm{yr}$ & 05May2014 1218 & 3.8 & 264.87 & 265.77 & 0.66 & 5.79 & 9.76 & 0.9 \\
\hline 2097.011 & Max WS & $5-\mathrm{yr}$ & 05May2014 1218 & 7.8 & 264.87 & 266.1 & 0.84 & 9.3 & 11.52 & 1.23 \\
\hline 2097.011 & Max WS & $10-y r$ & 05Мay2014 1218 & 12.12 & 264.87 & 266.36 & 0.97 & 12.48 & 13.22 & 1.49 \\
\hline 2097.011 & Max WS & $25-\mathrm{yr}$ & 05May2014 1218 & 17.27 & 264.87 & 266.62 & 1.06 & 16.22 & 14.98 & 1.75 \\
\hline 2097.011 & Max WS & $50-\mathrm{yr}$ & 05Мay2014 1218 & 20.03 & 264.87 & 266.74 & 1.11 & 18.06 & 15.69 & 1.87 \\
\hline 2097.011 & Max WS & $100-\mathrm{yr}$ & 05May2014 1218 & 24.89 & 264.87 & 266.95 & 1.16 & 21.47 & 17.19 & 2.08 \\
\hline 2097.011 & Max WS & $500-\mathrm{yr}$ & 05Мay2014 1218 & 36.42 & 264.87 & 267.36 & 1.23 & 32.1 & 33.7 & 2.49 \\
\hline 2052.742 & Max WS & $2-y r$ & 05Мау2014 1218 & 3.76 & 264.51 & 265.01 & 1.95 & 1.93 & 6.57 & 0.5 \\
\hline 2052.742 & Max WS & $5-\mathrm{yr}$ & 05Мay2014 1218 & 7.74 & 264.51 & 265.16 & 2.54 & 3.04 & 7.61 & 0.65 \\
\hline 2052.742 & Max WS & $10-y r$ & 05Мay2014 1218 & 12.05 & 264.51 & 265.31 & 2.87 & 4.2 & 8.55 & 0.8 \\
\hline 2052.742 & Max WS & $25-y r$ & 05Мay2014 1218 & 17.19 & 264.51 & 265.41 & 3.34 & 5.15 & 9.11 & 0.9 \\
\hline 2052.742 & Max WS & $50-\mathrm{yr}$ & 05Мay2014 1218 & 19.96 & 264.51 & 265.47 & 3.51 & 5.69 & 9.41 & 0.96 \\
\hline 2052.742 & Max WS & $100-\mathrm{yr}$ & 05Мay2014 1218 & 24.78 & 264.51 & 265.56 & 3.77 & 6.57 & 9.88 & 1.05 \\
\hline 2052.742 & Max WS & $500-\mathrm{yr}$ & 05Мay2014 1218 & 36.25 & 264.51 & 265.71 & 4.49 & 8.07 & 10.62 & 1.2 \\
\hline 2009.086 & Max WS & $2-y r$ & 05Мay2014 1218 & 3.72 & 263.84 & 264.28 & 1.17 & 3.17 & 10.53 & 0.44 \\
\hline 2009.086 & Max WS & $5-\mathrm{yr}$ & 05Мау2014 1218 & 7.69 & 263.84 & 264.47 & 1.45 & 5.32 & 12.45 & 0.63 \\
\hline 2009.086 & Max WS & $10-y r$ & 05May2014 1218 & 12 & 263.84 & 264.64 & 1.6 & 7.52 & 14.13 & 0.8 \\
\hline 2009.086 & Max WS & $25-y r$ & 05Мау2014 1218 & 17.13 & 263.84 & 264.79 & 1.74 & 9.86 & 15.68 & 0.95 \\
\hline 2009.086 & Max WS & $50-\mathrm{yr}$ & 05Мay2014 1218 & 19.9 & 263.84 & 264.86 & 1.82 & 10.95 & 16.35 & 1.02 \\
\hline 2009.086 & Max WS & $100-\mathrm{yr}$ & 05Мау2014 1218 & 24.73 & 263.84 & 264.96 & 1.97 & 12.58 & 17.25 & 1.12 \\
\hline 2009.086 & Max WS & $500-\mathrm{yr}$ & 05May2014 1218 & 36.18 & 263.84 & 265.17 & 2.2 & 16.47 & 19.17 & 1.33 \\
\hline 1964.49 & Max WS & $2-y r$ & 05Мау2014 1218 & 3.65 & 263.35 & 263.72 & 1.36 & 2.68 & 10.99 & 0.37 \\
\hline
\end{tabular}




\begin{tabular}{|c|c|c|c|c|c|c|c|c|c|c|}
\hline $\begin{array}{l}\text { River } \\
\text { Sta }\end{array}$ & Profile & Plan & Time at Max & $\begin{array}{c}\mathbf{Q} \\
\text { Total } \\
\left(\mathrm{m}^{3} / \mathbf{s}\right) \\
\end{array}$ & $\begin{array}{c}\text { Min } \\
\text { Ch El } \\
(\mathbf{m}) \\
\end{array}$ & $\begin{array}{l}\text { W.S. } \\
\text { Elev } \\
(\mathbf{m})\end{array}$ & $\begin{array}{l}\text { Vel } \\
\text { Chnl } \\
(\mathbf{m} / \mathbf{s}) \\
\end{array}$ & $\begin{array}{c}\text { Flow } \\
\text { Area } \\
\left(\mathbf{m}^{2}\right) \\
\end{array}$ & $\begin{array}{c}\text { Top } \\
\text { Width } \\
(\mathbf{m}) \\
\end{array}$ & $\begin{array}{c}\text { Max Ch } \\
\text { Dpth } \\
\text { (m) }\end{array}$ \\
\hline 1964.49 & Max WS & $5-y r$ & 05May2014 1218 & 7.63 & 263.35 & 263.88 & 1.66 & 4.59 & 13.31 & 0.53 \\
\hline 1964.49 & Max WS & $10-y r$ & 05May2014 1218 & 11.93 & 263.35 & 263.99 & 1.94 & 6.14 & 14.93 & 0.64 \\
\hline 1964.49 & Max WS & $25-\mathrm{yr}$ & 05May2014 1218 & 17.05 & 263.35 & 264.11 & 2.09 & 8.14 & 16.93 & 0.76 \\
\hline 1964.49 & Max WS & $50-y r$ & 05May2014 1218 & 19.83 & 263.35 & 264.15 & 2.23 & 8.88 & 17.65 & 0.8 \\
\hline 1964.49 & Max WS & $100-\mathrm{yr}$ & 05May2014 1218 & 24.64 & 263.35 & 264.23 & 2.41 & 10.23 & 18.89 & 0.88 \\
\hline 1964.49 & Max WS & $500-\mathrm{yr}$ & 05May2014 1218 & 36.07 & 263.35 & 264.39 & 2.67 & 13.52 & 21.52 & 1.04 \\
\hline 1925.761 & Max WS & $2-\mathrm{yr}$ & 05Мay2014 1224 & 3.58 & 263.04 & 263.38 & 0.86 & 4.18 & 18.58 & 0.34 \\
\hline 1925.761 & Max WS & $5-y r$ & 05Мay2014 1218 & 7.53 & 263.04 & 263.56 & 0.92 & 8.22 & 25.68 & 0.52 \\
\hline 1925.761 & Max WS & $10-y r$ & 05May2014 1218 & 11.81 & 263.04 & 263.68 & 1.03 & 11.73 & 31.81 & 0.64 \\
\hline 1925.761 & Max WS & $25-\mathrm{yr}$ & 05May2014 1218 & 16.86 & 263.04 & 263.82 & 1.1 & 16.4 & 37.78 & 0.78 \\
\hline 1925.761 & Max WS & $50-\mathrm{yr}$ & 05May2014 1218 & 19.62 & 263.04 & 263.88 & 1.13 & 18.86 & 41.02 & 0.84 \\
\hline 1925.761 & Max WS & $100-y r$ & 05May2014 1218 & 24.44 & 263.04 & 263.98 & 1.18 & 22.97 & 44.6 & 0.94 \\
\hline 1925.761 & Max WS & $500-\mathrm{yr}$ & 05May2014 1218 & 35.78 & 263.04 & 264.16 & 1.3 & 32.08 & 54.85 & 1.12 \\
\hline 1874.546 & Max WS & $2-\mathrm{yr}$ & 05May2014 1224 & 3.55 & 262.4 & 262.99 & 0.66 & 5.41 & 15.61 & 0.59 \\
\hline 1874.546 & Max WS & $5-y r$ & 05May2014 1218 & 7.13 & 262.4 & 263.16 & 0.85 & 8.38 & 19.51 & 0.76 \\
\hline 1874.546 & Max WS & $10-y r$ & 05May2014 1218 & 11.42 & 262.4 & 263.27 & 1.07 & 10.66 & 21.83 & 0.87 \\
\hline 1874.546 & Max WS & $25-y r$ & 05May2014 1218 & 16.3 & 262.4 & 263.4 & 1.2 & 13.65 & 24.83 & 1 \\
\hline 1874.546 & Max WS & $50-\mathrm{yr}$ & 05May2014 1218 & 19.04 & 262.4 & 263.44 & 1.3 & 14.79 & 25.84 & 1.04 \\
\hline 1874.546 & Max WS & $100-\mathrm{yr}$ & 05May2014 1218 & 23.82 & 262.4 & 263.51 & 1.46 & 16.53 & 27.53 & 1.11 \\
\hline 1874.546 & Max WS & $500-y r$ & 05May2014 1218 & 34.93 & 262.4 & 263.66 & 1.72 & 21.13 & 32.28 & 1.26 \\
\hline 1828.159 & Max WS & $2-\mathrm{yr}$ & 05May2014 1224 & 3.52 & 262.13 & 262.53 & 1.3 & 2.71 & 12.19 & 0.4 \\
\hline 1828.159 & Max WS & $5-y r$ & 05May2014 1224 & 7.19 & 262.13 & 262.67 & 1.5 & 4.78 & 16.47 & 0.54 \\
\hline 1828.159 & Max WS & $10-y r$ & 05May2014 1218 & 11.24 & 262.13 & 262.8 & 1.59 & 7.09 & 19.96 & 0.67 \\
\hline 1828.159 & Max WS & $25-y r$ & 05May2014 1218 & 16.09 & 262.13 & 262.91 & 1.68 & 9.6 & 23.23 & 0.78 \\
\hline 1828.159 & Max WS & $50-\mathrm{yr}$ & 05May2014 1218 & 18.86 & 262.13 & 262.96 & 1.77 & 10.64 & 24.36 & 0.83 \\
\hline 1828.159 & Max WS & $100-\mathrm{yr}$ & 05May2014 1218 & 23.6 & 262.13 & 263.04 & 1.88 & 12.63 & 26.32 & 0.91 \\
\hline 1828.159 & Max WS & $500-\mathrm{yr}$ & 05May2014 1218 & 34.62 & 262.13 & 263.21 & 2.04 & 17.49 & 30.79 & 1.08 \\
\hline 1788.723 & Max WS & $2-y r$ & 05 May2014 1230 & 3.39 & 261.54 & 262.25 & 0.43 & 7.82 & 21.06 & 0.71 \\
\hline 1788.723 & Max WS & $5-y r$ & 05May2014 1224 & 7.15 & 261.54 & 262.43 & 0.6 & 11.92 & 25.61 & 0.89 \\
\hline 1788.723 & Max WS & $10-y r$ & 05May2014 1218 & 11 & 261.54 & 262.58 & 0.69 & 16.17 & 29.25 & 1.04 \\
\hline 1788.723 & Max WS & $25-\mathrm{yr}$ & 05May2014 1218 & 15.84 & 261.54 & 262.71 & 0.81 & 20.1 & 32.09 & 1.17 \\
\hline 1788.723 & Max WS & $50-\mathrm{yr}$ & 05May2014 1218 & 18.57 & 261.54 & 262.77 & 0.87 & 22.19 & 33.34 & 1.23 \\
\hline 1788.723 & Max WS & $100-\mathrm{yr}$ & 05May2014 1218 & 23.3 & 261.54 & 262.88 & 0.95 & 25.81 & 35.64 & 1.34 \\
\hline 1788.723 & Max WS & $500-\mathrm{yr}$ & 05Мay2014 1218 & 34.21 & 261.54 & 263.08 & 1.1 & 33.52 & 39.62 & 1.54 \\
\hline 1742.556 & Max WS & $2-y r$ & 05Мay2014 1230 & 3.39 & 261.5 & 262.21 & 0.43 & 7.87 & 19 & 0.71 \\
\hline
\end{tabular}




\begin{tabular}{|c|c|c|c|c|c|c|c|c|c|c|}
\hline $\begin{array}{l}\text { River } \\
\text { Sta }\end{array}$ & Profile & Plan & Time at Max & $\begin{array}{c}\mathbf{Q} \\
\text { Total } \\
\left(\mathrm{m}^{3} / \mathbf{s}\right) \\
\end{array}$ & $\begin{array}{c}\text { Min } \\
\text { Ch El } \\
(\mathbf{m})\end{array}$ & $\begin{array}{l}\text { W.S. } \\
\text { Elev } \\
(\mathbf{m})\end{array}$ & $\begin{array}{c}\text { Vel } \\
\text { Chnl } \\
(\mathbf{m} / \mathbf{s}) \\
\end{array}$ & $\begin{array}{l}\text { Flow } \\
\text { Area } \\
\left(\mathbf{m}^{2}\right) \\
\end{array}$ & $\begin{array}{c}\text { Top } \\
\text { Width } \\
\text { (m) }\end{array}$ & $\begin{array}{c}\text { Max Chl } \\
\text { Dpth } \\
\text { (m) }\end{array}$ \\
\hline 1742.556 & Max WS & $5-y r$ & 05Мау2014 1224 & 7.1 & 261.5 & 262.36 & 0.65 & 10.95 & 22.17 & 0.86 \\
\hline 1742.556 & Max WS & $10-\mathrm{yr}$ & 05Мay2014 1218 & 10.66 & 261.5 & 262.5 & 0.74 & 14.49 & 25.29 & 1 \\
\hline 1742.556 & Max WS & $25-\mathrm{yr}$ & 05Мay2014 1218 & 15.54 & 261.5 & 262.61 & 0.9 & 17.39 & 27.51 & 1.11 \\
\hline 1742.556 & Max WS & $50-y r$ & 05Мay2014 1218 & 18.15 & 261.5 & 262.68 & 0.96 & 19.14 & 28.78 & 1.18 \\
\hline 1742.556 & Max WS & $100-\mathrm{yr}$ & 05Мay2014 1218 & 22.9 & 261.5 & 262.77 & 1.06 & 22.01 & 30.56 & 1.27 \\
\hline 1742.556 & Max WS & $500-\mathrm{yr}$ & 05Мay2014 1218 & 33.68 & 261.5 & 262.97 & 1.24 & 28.37 & 34.4 & 1.47 \\
\hline 1695.655 & Max WS & $2-y r$ & 05Мау2014 1230 & 3.38 & 261.28 & 261.72 & 1.4 & 2.41 & 9.25 & 0.44 \\
\hline 1695.655 & Max WS & $5-y r$ & 05Мay2014 1224 & 7.05 & 261.28 & 261.89 & 1.67 & 4.22 & 11.75 & 0.61 \\
\hline 1695.655 & Max WS & $10-y r$ & 05Мay2014 1224 & 10.98 & 261.28 & 262.07 & 1.69 & 6.48 & 13.94 & 0.79 \\
\hline 1695.655 & Max WS & $25-\mathrm{yr}$ & 05Мay2014 1224 & 15.42 & 261.28 & 262.22 & 1.77 & 8.74 & 16.1 & 0.94 \\
\hline 1695.655 & Max WS & $50-\mathrm{yr}$ & 05Мay2014 1224 & 17.84 & 261.28 & 262.3 & 1.76 & 10.16 & 17.7 & 1.02 \\
\hline 1695.655 & Max WS & $100-\mathrm{yr}$ & 05May2014 1224 & 22.02 & 261.28 & 262.42 & 1.8 & 12.5 & 20.6 & 1.14 \\
\hline 1695.655 & Max WS & $500-y r$ & 05Мay2014 1224 & 31.75 & 261.28 & 262.68 & 1.82 & 18.91 & 29.01 & 1.4 \\
\hline 1651.05 & Max WS & $2-y r$ & 05Мay2014 1230 & 3.35 & 260.78 & 261.35 & 0.64 & 5.22 & 14.18 & 0.57 \\
\hline 1651.05 & Max WS & $5-\mathrm{yr}$ & 05May2014 1230 & 6.71 & 260.78 & 261.63 & 0.7 & 9.54 & 16.9 & 0.85 \\
\hline 1651.05 & Max WS & $10-y r$ & 05Мay2014 1224 & 10.84 & 260.78 & 261.85 & 0.8 & 13.62 & 18.98 & 1.07 \\
\hline 1651.05 & Max WS & $25-\mathrm{yr}$ & 05Мay2014 1224 & 15.31 & 260.78 & 262.07 & 0.86 & 17.88 & 20.94 & 1.29 \\
\hline 1651.05 & Max WS & $50-y r$ & 05Мay2014 1224 & 17.72 & 260.78 & 262.17 & 0.88 & 20.06 & 21.81 & 1.39 \\
\hline 1651.05 & Max WS & $100-y r$ & 05Мay2014 1224 & 21.93 & 260.78 & 262.32 & 0.93 & 23.58 & 23.16 & 1.54 \\
\hline 1651.05 & Max WS & $500-y r$ & 05May2014 1224 & 31.65 & 260.78 & 262.62 & 1.02 & 30.95 & 25.92 & 1.84 \\
\hline 1617.21 & Max WS & $2-y r$ & 05Мay2014 1236 & 3.25 & 260.56 & 261.29 & 0.62 & 5.28 & 11.58 & 0.73 \\
\hline 1617.21 & Max WS & $5-\mathrm{yr}$ & 05Мay2014 1230 & 6.7 & 260.56 & 261.57 & 0.75 & 8.89 & 14.09 & 1.01 \\
\hline 1617.21 & Max WS & $10-y r$ & 05Мay2014 1224 & 10.7 & 260.56 & 261.79 & 0.87 & 12.3 & 16.2 & 1.23 \\
\hline 1617.21 & Max WS & $25-\mathrm{yr}$ & 05Мay2014 1224 & 15.2 & 260.56 & 262 & 0.95 & 15.93 & 18.04 & 1.44 \\
\hline 1617.21 & Max WS & $50-y r$ & 05Мay2014 1224 & 17.6 & 260.56 & 262.11 & 0.99 & 17.83 & 18.93 & 1.55 \\
\hline 1617.21 & Max WS & $100-\mathrm{yr}$ & 05May2014 1224 & 21.84 & 260.56 & 262.26 & 1.05 & 20.84 & 20.06 & 1.7 \\
\hline 1617.21 & Max WS & $500-\mathrm{yr}$ & 05May2014 1224 & 31.58 & 260.56 & 262.56 & 1.16 & 27.11 & 22.08 & 2 \\
\hline 1577.381 & Max WS & $2-y r$ & 05Мay2014 1236 & 3.25 & 260.48 & 261.26 & 0.2 & 16.5 & 27.07 & 0.78 \\
\hline 1577.381 & Max WS & $5-\mathrm{yr}$ & 05Мay2014 1230 & 6.66 & 260.48 & 261.55 & 0.27 & 24.73 & 29.97 & 1.07 \\
\hline 1577.381 & Max WS & $10-\mathrm{yr}$ & 05Мay2014 1224 & 10.46 & 260.48 & 261.78 & 0.33 & 31.87 & 32.05 & 1.3 \\
\hline 1577.381 & Max WS & $25-\mathrm{yr}$ & 05Мay2014 1224 & 15 & 260.48 & 262 & 0.38 & 39.08 & 34.31 & 1.52 \\
\hline 1577.381 & Max WS & $50-y r$ & 05Мay2014 1224 & 17.41 & 260.48 & 262.1 & 0.41 & 42.73 & 35.02 & 1.62 \\
\hline 1577.381 & Max WS & $100-y r$ & 05Мay2014 1224 & 21.69 & 260.48 & 262.26 & 0.45 & 48.44 & 38.29 & 1.78 \\
\hline 1577.381 & Max WS & $500-y r$ & 05Мау2014 1224 & 31.45 & 260.48 & 262.57 & 0.53 & 61.53 & 50.88 & 2.09 \\
\hline 1542.946 & Max WS & $2-y r$ & 05Мay2014 1236 & 3.24 & 260.49 & 261.14 & 1.13 & 2.88 & 6.19 & 0.65 \\
\hline
\end{tabular}




\begin{tabular}{|c|c|c|c|c|c|c|c|c|c|c|}
\hline $\begin{array}{l}\text { River } \\
\text { Sta }\end{array}$ & Profile & Plan & Time at Max & $\begin{array}{c}\mathbf{Q} \\
\text { Total } \\
\left(\mathrm{m}^{3} / \mathbf{s}\right) \\
\end{array}$ & $\begin{array}{c}\text { Min } \\
\text { Ch El } \\
(\mathbf{m}) \\
\end{array}$ & $\begin{array}{l}\text { W.S. } \\
\text { Elev } \\
(\mathbf{m})\end{array}$ & $\begin{array}{l}\text { Vel } \\
\text { Chnl } \\
(\mathbf{m} / \mathbf{s}) \\
\end{array}$ & $\begin{array}{c}\text { Flow } \\
\text { Area } \\
\left(\mathbf{m}^{2}\right) \\
\end{array}$ & $\begin{array}{c}\text { Top } \\
\text { Width } \\
(\mathbf{m}) \\
\end{array}$ & $\begin{array}{c}\text { Max Ch } \\
\text { Dpth } \\
\text { (m) }\end{array}$ \\
\hline 1542.946 & Max WS & $5-y r$ & 05May2014 1230 & 6.62 & 260.49 & 261.38 & 1.46 & 4.52 & 7.32 & 0.89 \\
\hline 1542.946 & Max WS & $10-y r$ & 05May2014 1224 & 10.29 & 260.49 & 261.57 & 1.73 & 5.95 & 8.19 & 1.08 \\
\hline 1542.946 & Max WS & $25-\mathrm{yr}$ & 05May2014 1224 & 14.86 & 260.49 & 261.75 & 1.97 & 7.55 & 9.07 & 1.26 \\
\hline 1542.946 & Max WS & $50-y r$ & 05May2014 1224 & 17.28 & 260.49 & 261.84 & 2.07 & 8.34 & 9.47 & 1.35 \\
\hline 1542.946 & Max WS & $100-\mathrm{yr}$ & 05 May2014 1224 & 21.58 & 260.49 & 261.97 & 2.23 & 9.67 & 10.08 & 1.48 \\
\hline 1542.946 & Max WS & $500-\mathrm{yr}$ & 05 May2014 1224 & 31.35 & 260.49 & 262.23 & 2.54 & 12.35 & 10.93 & 1.74 \\
\hline 1504.079 & Max WS & $2-y r$ & 05Мay2014 1236 & 3.24 & 260.31 & 260.88 & 1.19 & 2.73 & 7.78 & 0.57 \\
\hline 1504.079 & Max WS & $5-\mathrm{yr}$ & 05May2014 1230 & 6.61 & 260.31 & 261.11 & 1.43 & 4.61 & 8.82 & 0.8 \\
\hline 1504.079 & Max WS & $10-y r$ & 05May2014 1224 & 10.22 & 260.31 & 261.27 & 1.66 & 6.16 & 9.59 & 0.96 \\
\hline 1504.079 & Max WS & $25-\mathrm{yr}$ & 05 May2014 1224 & 14.8 & 260.31 & 261.44 & 1.88 & 7.85 & 10.36 & 1.13 \\
\hline 1504.079 & Max WS & $50-\mathrm{yr}$ & 05May2014 1224 & 17.21 & 260.31 & 261.52 & 1.98 & 8.69 & 10.72 & 1.21 \\
\hline 1504.079 & Max WS & $100-\mathrm{yr}$ & 05Маy2014 1224 & 21.52 & 260.31 & 261.65 & 2.15 & 10.03 & 11.28 & 1.34 \\
\hline 1504.079 & Max WS & $500-\mathrm{yr}$ & 05May2014 1224 & 31.31 & 260.31 & 261.84 & 2.53 & 12.35 & 12.18 & 1.53 \\
\hline 1467.659 & Max WS & $2-\mathrm{yr}$ & 05May2014 1236 & 3.23 & 260.12 & 260.71 & 0.87 & 3.71 & 9.22 & 0.59 \\
\hline 1467.659 & Max WS & $5-y r$ & 05May2014 1230 & 6.59 & 260.12 & 260.92 & 1.13 & 5.85 & 10.75 & 0.8 \\
\hline 1467.659 & Max WS & $10-y r$ & 05May2014 1230 & 10.08 & 260.12 & 261.11 & 1.26 & 8.02 & 12.17 & 0.99 \\
\hline 1467.659 & Max WS & $25-y r$ & 05May2014 1224 & 14.72 & 260.12 & 261.27 & 1.45 & 10.14 & 13.62 & 1.15 \\
\hline 1467.659 & Max WS & $50-\mathrm{yr}$ & 05May2014 1224 & 17.13 & 260.12 & 261.36 & 1.5 & 11.39 & 14.41 & 1.24 \\
\hline 1467.659 & Max WS & $100-\mathrm{yr}$ & 05May2014 1224 & 21.47 & 260.12 & 261.48 & 1.64 & 13.12 & 15.47 & 1.36 \\
\hline 1467.659 & Max WS & $500-y r$ & 05May2014 1224 & 31.25 & 260.12 & 261.69 & 1.89 & 16.57 & 17.45 & 1.57 \\
\hline 1425.307 & Max WS & $2-y r$ & 05May2014 1236 & 3.23 & 259.66 & 260.16 & 1.59 & 2.03 & 6.86 & 0.5 \\
\hline 1425.307 & Max WS & $5-y r$ & 05May2014 1230 & 6.56 & 259.66 & 260.34 & 1.91 & 3.44 & 8.41 & 0.68 \\
\hline 1425.307 & Max WS & $10-y r$ & 05May2014 1224 & 10.05 & 259.66 & 260.48 & 2.14 & 4.69 & 9.58 & 0.82 \\
\hline 1425.307 & Max WS & $25-y r$ & 05May2014 1224 & 14.62 & 259.66 & 260.64 & 2.32 & 6.31 & 11.07 & 0.98 \\
\hline 1425.307 & Max WS & $50-\mathrm{yr}$ & 05May2014 1224 & 17.03 & 259.66 & 260.72 & 2.37 & 7.18 & 11.89 & 1.06 \\
\hline 1425.307 & Max WS & $100-\mathrm{yr}$ & 05May2014 1224 & 21.39 & 259.66 & 260.81 & 2.55 & 8.39 & 12.95 & 1.15 \\
\hline 1425.307 & Max WS & $500-\mathrm{yr}$ & 05May2014 1224 & 31.17 & 259.66 & 261.03 & 2.73 & 11.55 & 16.88 & 1.37 \\
\hline 1392.843 & Max WS & $2-y r$ & 05 May2014 1236 & 3.23 & 259.14 & 259.67 & 1.44 & 2.23 & 7.3 & 0.53 \\
\hline 1392.843 & Max WS & $5-y r$ & 05May2014 1230 & 6.54 & 259.14 & 259.86 & 1.72 & 3.8 & 8.91 & 0.72 \\
\hline 1392.843 & Max WS & $10-y r$ & 05May2014 1230 & 10.07 & 259.14 & 260.01 & 1.92 & 5.24 & 9.76 & 0.87 \\
\hline 1392.843 & Max WS & $25-\mathrm{yr}$ & 05May2014 1224 & 14.55 & 259.14 & 260.16 & 2.15 & 6.76 & 10.59 & 1.02 \\
\hline 1392.843 & Max WS & $50-\mathrm{yr}$ & 05May2014 1224 & 16.96 & 259.14 & 260.25 & 2.21 & 7.67 & 11.05 & 1.11 \\
\hline 1392.843 & Max WS & $100-\mathrm{yr}$ & 05May2014 1224 & 21.34 & 259.14 & 260.37 & 2.35 & 9.1 & 11.8 & 1.23 \\
\hline 1392.843 & Max WS & $500-\mathrm{yr}$ & 05May2014 1224 & 31.1 & 259.14 & 260.62 & 2.54 & 12.22 & 14.11 & 1.47 \\
\hline 1358.799 & Max WS & $2-y r$ & 05Мay2014 1236 & 3.22 & 258.63 & 259.12 & 1.54 & 2.09 & 7.18 & 0.49 \\
\hline
\end{tabular}




\begin{tabular}{|c|c|c|c|c|c|c|c|c|c|c|}
\hline $\begin{array}{l}\text { River } \\
\text { Sta }\end{array}$ & Profile & Plan & Time at Max & $\begin{array}{c}\mathbf{Q} \\
\text { Total } \\
\left(\mathrm{m}^{3} / \mathbf{s}\right)\end{array}$ & $\begin{array}{c}\text { Min } \\
\text { Ch El } \\
\text { (m) }\end{array}$ & $\begin{array}{l}\text { W.S. } \\
\text { Elev } \\
(\mathbf{m})\end{array}$ & $\begin{array}{c}\text { Vel } \\
\text { Chnl } \\
(\mathbf{m} / \mathbf{s}) \\
\end{array}$ & $\begin{array}{c}\text { Flow } \\
\text { Area } \\
\left(\mathbf{m}^{2}\right) \\
\end{array}$ & $\begin{array}{c}\text { Top } \\
\text { Width } \\
\text { (m) }\end{array}$ & $\begin{array}{c}\text { Max Chl } \\
\text { Dpth } \\
\text { (m) }\end{array}$ \\
\hline 1358.799 & Max WS & $5-\mathrm{yr}$ & 05May2014 1230 & 6.52 & 258.63 & 259.29 & 1.92 & 3.39 & 8.35 & 0.66 \\
\hline 1358.799 & Max WS & $10-\mathrm{yr}$ & 05May2014 1230 & 10.07 & 258.63 & 259.43 & 2.16 & 4.67 & 9.23 & 0.8 \\
\hline 1358.799 & Max WS & $25-\mathrm{yr}$ & 05May2014 1224 & 14.49 & 258.63 & 259.58 & 2.4 & 6.03 & 10.08 & 0.95 \\
\hline 1358.799 & Max WS & $50-y r$ & 05Маy2014 1224 & 16.89 & 258.63 & 259.64 & 2.52 & 6.71 & 10.48 & 1.01 \\
\hline 1358.799 & Max WS & $100-\mathrm{yr}$ & 05May2014 1224 & 21.28 & 258.63 & 259.75 & 2.69 & 7.91 & 11.16 & 1.12 \\
\hline 1358.799 & Max WS & $500-\mathrm{yr}$ & 05May2014 1224 & 31.04 & 258.63 & 259.97 & 2.97 & 10.46 & 12.49 & 1.34 \\
\hline 1329.439 & Max WS & $2-\mathrm{yr}$ & 05Мay2014 1230 & 3.09 & 258.21 & 258.72 & 1.28 & 2.4 & 7.63 & 0.51 \\
\hline 1329.439 & Max WS & $5-\mathrm{yr}$ & 05May2014 1230 & 6.49 & 258.21 & 258.93 & 1.55 & 4.18 & 9.12 & 0.72 \\
\hline 1329.439 & Max WS & $10-\mathrm{yr}$ & 05May2014 1230 & 10.06 & 258.21 & 259.08 & 1.79 & 5.61 & 10.02 & 0.87 \\
\hline 1329.439 & Max WS & $25-\mathrm{yr}$ & 05May2014 1224 & 14.42 & 258.21 & 259.27 & 1.9 & 7.6 & 11.15 & 1.06 \\
\hline 1329.439 & Max WS & $50-\mathrm{yr}$ & 05May2014 1224 & 16.83 & 258.21 & 259.35 & 1.98 & 8.49 & 11.62 & 1.14 \\
\hline 1329.439 & Max WS & $100-\mathrm{yr}$ & 05May2014 1224 & 21.21 & 258.21 & 259.49 & 2.08 & 10.19 & 12.47 & 1.28 \\
\hline 1329.439 & Max WS & $500-\mathrm{yr}$ & 05May2014 1224 & 30.97 & 258.21 & 259.78 & 2.21 & 14.03 & 14.15 & 1.57 \\
\hline 1302.462 & Max WS & $2-\mathrm{yr}$ & 05May2014 1230 & 3.07 & 257.76 & 258.62 & 0.4 & 7.62 & 12.69 & 0.86 \\
\hline 1302.462 & Max WS & $5-y r$ & 05May2014 1230 & 6.45 & 257.76 & 258.86 & 0.6 & 10.82 & 14.19 & 1.1 \\
\hline 1302.462 & Max WS & $10-\mathrm{yr}$ & 05May2014 1230 & 10.05 & 257.76 & 259.03 & 0.75 & 13.35 & 15.31 & 1.27 \\
\hline 1302.462 & Max WS & $25-\mathrm{yr}$ & 05May2014 1224 & 14.3 & 257.76 & 259.25 & 0.85 & 16.77 & 16.72 & 1.49 \\
\hline 1302.462 & Max WS & $50-\mathrm{yr}$ & 05May2014 1224 & 16.73 & 257.76 & 259.34 & 0.91 & 18.3 & 17.32 & 1.58 \\
\hline 1302.462 & Max WS & $100-\mathrm{yr}$ & 05May2014 1224 & 21.11 & 257.76 & 259.5 & 1 & 21.11 & 18.39 & 1.74 \\
\hline 1302.462 & Max WS & $500-\mathrm{yr}$ & 05May2014 1224 & 30.88 & 257.76 & 259.82 & 1.13 & 27.39 & 20.62 & 2.06 \\
\hline 1264.23 & Max WS & $2-y r$ & 05May2014 1242 & 3.19 & 257.59 & 258.13 & 1.34 & 2.38 & 7.1 & 0.54 \\
\hline 1264.23 & Max WS & $5-y r$ & 05May2014 1236 & 6.33 & 257.59 & 258.34 & 1.59 & 3.99 & 8.61 & 0.75 \\
\hline 1264.23 & Max WS & $10-\mathrm{yr}$ & 05May2014 1230 & 10.01 & 257.59 & 258.51 & 1.81 & 5.52 & 9.47 & 0.92 \\
\hline 1264.23 & Max WS & $25-\mathrm{yr}$ & 05May2014 1230 & 14.12 & 257.59 & 258.65 & 2.02 & 6.99 & 10.2 & 1.06 \\
\hline 1264.23 & Max WS & $50-\mathrm{yr}$ & 05 May2014 1230 & 16.29 & 257.59 & 258.72 & 2.12 & 7.7 & 10.54 & 1.13 \\
\hline 1264.23 & Max WS & $100-\mathrm{yr}$ & 05 May2014 1224 & 20.83 & 257.59 & 258.84 & 2.32 & 8.97 & 11.12 & 1.25 \\
\hline 1264.23 & Max WS & $500-\mathrm{yr}$ & 05Мay2014 1224 & 30.63 & 257.59 & 259.05 & 2.69 & 11.4 & 12.16 & 1.46 \\
\hline 1230.005 & Max WS & $2-y r$ & 05May2014 1242 & 3.18 & 257.24 & 257.98 & 0.67 & 4.74 & 9.53 & 0.74 \\
\hline 1230.005 & Max WS & $5-y r$ & 05May2014 1236 & 6.33 & 257.24 & 258.18 & 0.93 & 6.8 & 10.81 & 0.94 \\
\hline 1230.005 & Max WS & $10-y r$ & 05Мay2014 1230 & 9.97 & 257.24 & 258.38 & 1.1 & 9.04 & 12.05 & 1.14 \\
\hline 1230.005 & Max WS & $25-\mathrm{yr}$ & 05May2014 1230 & 14.11 & 257.24 & 258.52 & 1.3 & 10.85 & 12.97 & 1.28 \\
\hline 1230.005 & Max WS & $50-\mathrm{yr}$ & 05May2014 1230 & 16.28 & 257.24 & 258.6 & 1.37 & 11.85 & 13.45 & 1.36 \\
\hline 1230.005 & Max WS & $100-\mathrm{yr}$ & 05May2014 1224 & 20.72 & 257.24 & 258.72 & 1.53 & 13.54 & 14.1 & 1.48 \\
\hline 1230.005 & Max WS & $500-\mathrm{yr}$ & 05Мay2014 1224 & 30.52 & 257.24 & 258.93 & 1.83 & 16.64 & 15.22 & 1.69 \\
\hline 1191.977 & Max WS & $2-\mathrm{yr}$ & 05May2014 1242 & 3.16 & 256.91 & 257.91 & 0.37 & 8.52 & 12.68 & 1 \\
\hline
\end{tabular}




\begin{tabular}{|c|c|c|c|c|c|c|c|c|c|c|}
\hline $\begin{array}{l}\text { River } \\
\text { Sta }\end{array}$ & Profile & Plan & Time at Max & $\begin{array}{c}\mathbf{Q} \\
\text { Total } \\
\left(\mathbf{m}^{3} / \mathbf{s}\right)\end{array}$ & $\begin{array}{l}\text { Min } \\
\text { Ch El } \\
(\mathbf{m})\end{array}$ & $\begin{array}{l}\text { W.S. } \\
\text { Elev } \\
(\mathbf{m})\end{array}$ & $\begin{array}{l}\text { Vel } \\
\text { Chnl } \\
(\mathbf{m} / \mathbf{s})\end{array}$ & $\begin{array}{l}\text { Flow } \\
\text { Area } \\
\left(\mathbf{m}^{2}\right)\end{array}$ & $\begin{array}{c}\text { Top } \\
\text { Width } \\
\text { (m) }\end{array}$ & $\begin{array}{c}\text { Max Chl } \\
\text { Dpth } \\
\text { (m) }\end{array}$ \\
\hline 1191.977 & Max WS & $5-y r$ & 05May2014 1236 & 6.31 & 256.91 & 258.08 & 0.58 & 10.83 & 13.81 & 1.17 \\
\hline 1191.977 & Max WS & $10-\mathrm{yr}$ & 05May2014 1230 & 9.85 & 256.91 & 258.26 & 0.74 & 13.4 & 14.96 & 1.35 \\
\hline 1191.977 & Max WS & $25-\mathrm{yr}$ & 05Мay2014 1230 & 14.05 & 256.91 & 258.38 & 0.92 & 15.2 & 15.77 & 1.47 \\
\hline 1191.977 & Max WS & $50-\mathrm{yr}$ & 05May2014 1230 & 16.23 & 256.91 & 258.45 & 1 & 16.27 & 18.62 & 1.54 \\
\hline 1191.977 & Max WS & $100-\mathrm{yr}$ & 05 May2014 1230 & 20.07 & 256.91 & 258.55 & 1.1 & 18.89 & 28.11 & 1.64 \\
\hline 1191.977 & Max WS & $500-\mathrm{yr}$ & 05 May2014 1224 & 29.92 & 256.91 & 258.76 & 1.32 & 26.05 & 46.62 & 1.85 \\
\hline 1155.309 & Max WS & $2-\mathrm{yr}$ & 05Мay2014 1242 & 3.15 & 257.11 & 257.85 & 0.68 & 4.68 & 11.13 & 0.74 \\
\hline 1155.309 & Max WS & $5-y r$ & 05Мay2014 1236 & 6.29 & 257.11 & 258 & 1 & 6.83 & 20.23 & 0.89 \\
\hline 1155.309 & Max WS & $10-\mathrm{yr}$ & 05May2014 1230 & 9.77 & 257.11 & 258.17 & 1.04 & 11.2 & 28.15 & 1.06 \\
\hline 1155.309 & Max WS & $25-\mathrm{yr}$ & 05 May2014 1230 & 13.98 & 257.11 & 258.3 & 1.13 & 14.94 & 31.63 & 1.19 \\
\hline 1155.309 & Max WS & $50-\mathrm{yr}$ & 05May2014 1230 & 16.18 & 257.11 & 258.37 & 1.18 & 17.55 & 40.78 & 1.26 \\
\hline 1155.309 & Max WS & $100-\mathrm{yr}$ & 05Маy2014 1230 & 20.06 & 257.11 & 258.49 & 1.13 & 22.45 & 43.8 & 1.38 \\
\hline 1155.309 & Max WS & $500-\mathrm{yr}$ & 05May2014 1224 & 29.43 & 257.11 & 258.72 & 1.08 & 33.02 & 47.97 & 1.61 \\
\hline 1124.025 & Max WS & $2-\mathrm{yr}$ & 05May2014 1242 & 3.14 & 255.94 & 256.41 & 1.91 & 1.64 & 6.53 & 0.47 \\
\hline 1124.025 & Max WS & $5-\mathrm{yr}$ & 05May2014 1236 & 6.27 & 255.94 & 256.54 & 2.46 & 2.55 & 7.3 & 0.6 \\
\hline 1124.025 & Max WS & $10-\mathrm{yr}$ & 05May2014 1230 & 9.64 & 255.94 & 256.67 & 2.69 & 3.58 & 7.88 & 0.73 \\
\hline 1124.025 & Max WS & $25-\mathrm{yr}$ & 05May2014 1230 & 13.86 & 255.94 & 256.8 & 3.01 & 4.6 & 8.41 & 0.86 \\
\hline 1124.025 & Max WS & $50-\mathrm{yr}$ & 05May2014 1230 & 16.1 & 255.94 & 256.86 & 3.16 & 5.1 & 8.66 & 0.92 \\
\hline 1124.025 & Max WS & $100-\mathrm{yr}$ & 05Мay2014 1230 & 20.02 & 255.94 & 256.96 & 3.32 & 6.04 & 9.11 & 1.02 \\
\hline 1124.025 & Max WS & $500-\mathrm{yr}$ & 05May2014 1230 & 28.88 & 255.94 & 257.14 & 3.72 & 7.76 & 9.84 & 1.2 \\
\hline 1083.982 & Max WS & $2-\mathrm{yr}$ & 05May2014 1242 & 3.13 & 255 & 255.79 & 0.71 & 4.42 & 8.28 & 0.79 \\
\hline 1083.982 & Max WS & $5-\mathrm{yr}$ & 05May2014 1236 & 6.25 & 255 & 256.03 & 0.95 & 6.58 & 9.37 & 1.03 \\
\hline 1083.982 & Max WS & $10-\mathrm{yr}$ & 05May2014 1236 & 9.56 & 255 & 256.21 & 1.15 & 8.32 & 10.1 & 1.21 \\
\hline 1083.982 & Max WS & $25-\mathrm{yr}$ & 05May2014 1230 & 13.82 & 255 & 256.41 & 1.32 & 10.46 & 10.93 & 1.41 \\
\hline 1083.982 & Max WS & $50-y r$ & 05May2014 1230 & 16.06 & 255 & 256.5 & 1.41 & 11.43 & 11.28 & 1.5 \\
\hline 1083.982 & Max WS & $100-y r$ & 05May2014 1230 & 19.99 & 255 & 256.65 & 1.52 & 13.15 & 11.9 & 1.65 \\
\hline 1083.982 & Max WS & $500-y r$ & 05May2014 1230 & 28.87 & 255 & 256.92 & 1.75 & 16.49 & 13.02 & 1.92 \\
\hline 1018.257 & Max WS & $2-y r$ & 05 May2014 1242 & 3.11 & 254.8 & 255.36 & 1.3 & 2.39 & 7.19 & 0.56 \\
\hline 1018.257 & Max WS & $5-\mathrm{yr}$ & 05May2014 1236 & 6.21 & 254.8 & 255.58 & 1.5 & 4.14 & 8.45 & 0.78 \\
\hline 1018.257 & Max WS & $10-\mathrm{yr}$ & 05May2014 1236 & 9.55 & 254.8 & 255.73 & 1.74 & 5.48 & 9.04 & 0.93 \\
\hline 1018.257 & Max WS & $25-\mathrm{yr}$ & 05May2014 1230 & 13.73 & 254.8 & 255.9 & 1.94 & 7.07 & 9.68 & 1.1 \\
\hline 1018.257 & Max WS & $50-\mathrm{yr}$ & 05May2014 1230 & 15.98 & 254.8 & 255.98 & 2.04 & 7.82 & 9.97 & 1.18 \\
\hline 1018.257 & Max WS & $100-\mathrm{yr}$ & 05May2014 1230 & 19.93 & 254.8 & 256.11 & 2.17 & 9.17 & 10.48 & 1.31 \\
\hline 1018.257 & Max WS & $500-y r$ & 05May2014 1230 & 28.83 & 254.8 & 256.35 & 2.44 & 11.85 & 13.35 & 1.55 \\
\hline 959.582 & Max WS & $2-\mathrm{yr}$ & 05Мay2014 1242 & 3.09 & 254.42 & 255.01 & 0.88 & 3.5 & 8.88 & 0.59 \\
\hline
\end{tabular}




\begin{tabular}{|c|c|c|c|c|c|c|c|c|c|c|}
\hline $\begin{array}{l}\text { River } \\
\text { Sta }\end{array}$ & Profile & Plan & Time at Max & $\begin{array}{c}\mathbf{Q} \\
\text { Total } \\
\left(\mathrm{m}^{3} / \mathbf{s}\right) \\
\end{array}$ & $\begin{array}{c}\text { Min } \\
\text { Ch El } \\
\text { (m) }\end{array}$ & $\begin{array}{l}\text { W.S. } \\
\text { Elev } \\
(\mathbf{m})\end{array}$ & $\begin{array}{c}\text { Vel } \\
\text { Chnl } \\
(\mathbf{m} / \mathbf{s}) \\
\end{array}$ & $\begin{array}{l}\text { Flow } \\
\text { Area } \\
\left(\mathbf{m}^{2}\right) \\
\end{array}$ & $\begin{array}{c}\text { Top } \\
\text { Width } \\
\text { (m) }\end{array}$ & $\begin{array}{c}\text { Max Chl } \\
\text { Dpth } \\
\text { (m) }\end{array}$ \\
\hline 959.582 & Max WS & $5-y r$ & 05Мay2014 1236 & 6.16 & 254.42 & 255.22 & 1.11 & 5.53 & 10.17 & 0.8 \\
\hline 959.582 & Max WS & $10-\mathrm{yr}$ & 05Мay2014 1236 & 9.53 & 254.42 & 255.39 & 1.29 & 7.38 & 11.18 & 0.97 \\
\hline 959.582 & Max WS & $25-\mathrm{yr}$ & 05Мay2014 1230 & 13.62 & 254.42 & 255.57 & 1.44 & 9.43 & 11.96 & 1.15 \\
\hline 959.582 & Max WS & $50-y r$ & 05Мay2014 1230 & 15.88 & 254.42 & 255.66 & 1.51 & 10.5 & 12.34 & 1.24 \\
\hline 959.582 & Max WS & $100-\mathrm{yr}$ & 05Мay2014 1230 & 19.84 & 254.42 & 255.81 & 1.61 & 12.35 & 12.97 & 1.39 \\
\hline 959.582 & Max WS & $500-\mathrm{yr}$ & 05Мay2014 1230 & 28.76 & 254.42 & 256.08 & 1.76 & 17.28 & 25.03 & 1.66 \\
\hline 917.744 & Max WS & $2-y r$ & 05Мау2014 1248 & 3.08 & 253.94 & 254.52 & 1.22 & 2.51 & 7.67 & 0.58 \\
\hline 917.744 & Max WS & $5-y r$ & 05Мay2014 1242 & 6.07 & 253.94 & 254.75 & 1.37 & 4.43 & 8.82 & 0.81 \\
\hline 917.744 & Max WS & $10-y r$ & 05Мay2014 1236 & 9.5 & 253.94 & 254.95 & 1.51 & 6.3 & 9.81 & 1.01 \\
\hline 917.744 & Max WS & $25-\mathrm{yr}$ & 05Мay2014 1230 & 13.46 & 253.94 & 255.12 & 1.68 & 8.03 & 10.62 & 1.18 \\
\hline 917.744 & Max WS & $50-\mathrm{yr}$ & 05Мay2014 1230 & 15.72 & 253.94 & 255.22 & 1.73 & 9.06 & 11.07 & 1.28 \\
\hline 917.744 & Max WS & $100-\mathrm{yr}$ & 05May2014 1230 & 19.7 & 253.94 & 255.36 & 1.84 & 10.69 & 11.72 & 1.42 \\
\hline 917.744 & Max WS & $500-\mathrm{yr}$ & 05Мay2014 1230 & 28.63 & 253.94 & 255.65 & 2.01 & 14.23 & 12.97 & 1.71 \\
\hline 885.843 & Max WS & $2-y r$ & 05Мay2014 1248 & 3.08 & 253.61 & 254.27 & 1.22 & 2.53 & 6.26 & 0.66 \\
\hline 885.843 & Max WS & $5-\mathrm{yr}$ & 05Мay2014 1236 & 6.05 & 253.61 & 254.47 & 1.54 & 3.93 & 7.44 & 0.86 \\
\hline 885.843 & Max WS & $10-y r$ & 05Мay2014 1236 & 9.48 & 253.61 & 254.67 & 1.71 & 5.55 & 8.6 & 1.06 \\
\hline 885.843 & Max WS & $25-\mathrm{yr}$ & 05Мay2014 1230 & 13.4 & 253.61 & 254.84 & 1.89 & 7.1 & 9.58 & 1.23 \\
\hline 885.843 & Max WS & $50-y r$ & 05Мay2014 1230 & 15.66 & 253.61 & 254.94 & 1.95 & 8.03 & 9.96 & 1.33 \\
\hline 885.843 & Max WS & $100-y r$ & 05Мay2014 1230 & 19.65 & 253.61 & 255.09 & 2.05 & 9.6 & 10.56 & 1.48 \\
\hline 885.843 & Max WS & $500-\mathrm{yr}$ & 05May2014 1230 & 28.58 & 253.61 & 255.39 & 2.21 & 12.94 & 11.59 & 1.78 \\
\hline 831.018 & Max WS & $2-y r$ & 05Мay2014 1248 & 3.07 & 252.63 & 253 & 2.13 & 1.44 & 5.69 & 0.37 \\
\hline 831.018 & Max WS & $5-\mathrm{yr}$ & 05Мay2014 1242 & 6.07 & 252.63 & 253.16 & 2.46 & 2.47 & 6.58 & 0.53 \\
\hline 831.018 & Max WS & $10-y r$ & 05Мay2014 1236 & 9.46 & 252.63 & 253.3 & 2.8 & 3.38 & 7.26 & 0.67 \\
\hline 831.018 & Max WS & $25-\mathrm{yr}$ & 05Мay2014 1236 & 13.31 & 252.63 & 253.43 & 3.04 & 4.38 & 7.94 & 0.8 \\
\hline 831.018 & Max WS & $50-\mathrm{yr}$ & 05Мay2014 1230 & 15.58 & 252.63 & 253.48 & 3.22 & 4.83 & 8.23 & 0.85 \\
\hline 831.018 & Max WS & $100-\mathrm{yr}$ & 05May2014 1230 & 19.58 & 252.63 & 253.58 & 3.46 & 5.67 & 8.74 & 0.95 \\
\hline 831.018 & Max WS & $500-\mathrm{yr}$ & 05May2014 1230 & 28.52 & 252.63 & 253.77 & 3.86 & 7.39 & 9.69 & 1.14 \\
\hline 794.448 & Max WS & $2-y r$ & 05Мay2014 1248 & 3.07 & 251.86 & 252.43 & 0.99 & 3.09 & 7.64 & 0.57 \\
\hline 794.448 & Max WS & $5-\mathrm{yr}$ & 05Мay2014 1242 & 6.06 & 251.86 & 252.69 & 1.15 & 5.29 & 9.27 & 0.83 \\
\hline 794.448 & Max WS & $10-\mathrm{yr}$ & 05Мay2014 1236 & 9.44 & 251.86 & 252.86 & 1.36 & 6.96 & 10.34 & 1 \\
\hline 794.448 & Max WS & $25-\mathrm{yr}$ & 05Мay2014 1236 & 13.3 & 251.86 & 253.05 & 1.47 & 9.03 & 11.52 & 1.19 \\
\hline 794.448 & Max WS & $50-y r$ & 05Мay2014 1236 & 15.32 & 251.86 & 253.13 & 1.53 & 10.03 & 12.05 & 1.27 \\
\hline 794.448 & Max WS & $100-y r$ & 05May2014 1230 & 19.51 & 251.86 & 253.27 & 1.67 & 11.67 & 12.83 & 1.41 \\
\hline 794.448 & Max WS & $500-\mathrm{yr}$ & 05Мay2014 1230 & 28.47 & 251.86 & 253.54 & 1.85 & 15.42 & 14.21 & 1.68 \\
\hline 753.27 & Max WS & $2-y r$ & 05Мау2014 1248 & 3.06 & 251.5 & 252.05 & 1.4 & 2.19 & 6.61 & 0.55 \\
\hline
\end{tabular}




\begin{tabular}{|c|c|c|c|c|c|c|c|c|c|c|}
\hline $\begin{array}{l}\text { River } \\
\text { Sta }\end{array}$ & Profile & Plan & Time at Max & $\begin{array}{c}Q \\
\text { Total } \\
\left(\mathrm{m}^{3} / \mathbf{s}\right)\end{array}$ & $\begin{array}{c}\text { Min } \\
\text { Ch El } \\
(\mathbf{m})\end{array}$ & $\begin{array}{l}\text { W.S. } \\
\text { Elev } \\
(\mathbf{m})\end{array}$ & $\begin{array}{l}\text { Vel } \\
\text { Chnl } \\
(\mathrm{m} / \mathrm{s}) \\
\end{array}$ & $\begin{array}{l}\text { Flow } \\
\text { Area } \\
\left(\mathbf{m}^{2}\right) \\
\end{array}$ & $\begin{array}{c}\text { Top } \\
\text { Width } \\
\text { (m) }\end{array}$ & $\begin{array}{c}\text { Max Chl } \\
\text { Dpth } \\
\text { (m) }\end{array}$ \\
\hline 753.27 & Max WS & $5-y r$ & 05May2014 1242 & 6.06 & 251.5 & 252.24 & 1.7 & 3.56 & 8.17 & 0.74 \\
\hline 753.27 & Max WS & $10-\mathrm{yr}$ & 05May2014 1236 & 9.41 & 251.5 & 252.38 & 1.96 & 4.79 & 8.96 & 0.88 \\
\hline 753.27 & Max WS & $25-\mathrm{yr}$ & 05May2014 1236 & 13.29 & 251.5 & 252.51 & 2.23 & 5.97 & 9.58 & 1.01 \\
\hline 753.27 & Max WS & $50-\mathrm{yr}$ & 05Мay2014 1230 & 15.41 & 251.5 & 252.58 & 2.3 & 6.7 & 9.94 & 1.08 \\
\hline 753.27 & Max WS & $100-\mathrm{yr}$ & 05May2014 1230 & 19.43 & 251.5 & 252.69 & 2.5 & 7.77 & 10.44 & 1.19 \\
\hline 753.27 & Max WS & $500-y r$ & 05May2014 1230 & 28.4 & 251.5 & 252.9 & 2.81 & 10.11 & 11.4 & 1.4 \\
\hline 720.714 & Max WS & $2-y r$ & 05Мay2014 1248 & 3.06 & 251.09 & 251.58 & 1.48 & 2.06 & 7.11 & 0.49 \\
\hline 720.714 & Max WS & $5-\mathrm{yr}$ & 05May2014 1242 & 6.05 & 251.09 & 251.74 & 1.81 & 3.35 & 8.35 & 0.65 \\
\hline 720.714 & Max WS & $10-\mathrm{yr}$ & 05May2014 1236 & 9.39 & 251.09 & 251.9 & 2 & 4.69 & 9.33 & 0.8 \\
\hline 720.714 & Max WS & $25-\mathrm{yr}$ & 05May2014 1236 & 13.29 & 251.09 & 252.04 & 2.19 & 6.07 & 10.15 & 0.95 \\
\hline 720.714 & Max WS & $50-\mathrm{yr}$ & 05Мay2014 1236 & 15.32 & 251.09 & 252.11 & 2.26 & 6.79 & 10.55 & 1.02 \\
\hline 720.714 & Max WS & $100-\mathrm{yr}$ & 05Мay2014 1230 & 19.38 & 251.09 & 252.21 & 2.44 & 7.93 & 11.15 & 1.12 \\
\hline 720.714 & Max WS & $500-\mathrm{yr}$ & 05May2014 1230 & 28.35 & 251.09 & 252.42 & 2.74 & 10.36 & 12.33 & 1.33 \\
\hline 673.556 & Max WS & $2-y r$ & 05May2014 1254 & 2.99 & 250.52 & 251.24 & 0.37 & 8.13 & 17.23 & 0.72 \\
\hline 673.556 & Max WS & $5-\mathrm{yr}$ & 05Мay2014 1242 & 6.01 & 250.52 & 251.46 & 0.49 & 12.27 & 20.64 & 0.94 \\
\hline 673.556 & Max WS & $10-\mathrm{yr}$ & 05Мay2014 1236 & 9.3 & 250.52 & 251.63 & 0.58 & 16.16 & 23.36 & 1.11 \\
\hline 673.556 & Max WS & $25-\mathrm{yr}$ & 05Мay2014 1236 & 13.23 & 250.52 & 251.82 & 0.63 & 20.87 & 26.38 & 1.3 \\
\hline 673.556 & Max WS & $50-\mathrm{yr}$ & 05May2014 1236 & 15.28 & 250.52 & 251.91 & 0.66 & 23.09 & 27.78 & 1.39 \\
\hline 673.556 & Max WS & $100-\mathrm{yr}$ & 05May2014 1230 & 19.16 & 250.52 & 252.03 & 0.72 & 26.57 & 29.99 & 1.51 \\
\hline 673.556 & Max WS & $500-\mathrm{yr}$ & 05May2014 1230 & 28.12 & 250.52 & 252.28 & 0.81 & 34.57 & 34.28 & 1.76 \\
\hline 625.562 & Max WS & $2-y r$ & 05May2014 1254 & 2.99 & 250.47 & 251.17 & 0.62 & 4.84 & 11.12 & 0.7 \\
\hline 625.562 & Max WS & $5-y r$ & 05May2014 1242 & 5.96 & 250.47 & 251.36 & 0.84 & 7.12 & 12.82 & 0.89 \\
\hline 625.562 & Max WS & $10-\mathrm{yr}$ & 05May2014 1236 & 9.18 & 250.47 & 251.51 & 1.01 & 9.12 & 14.25 & 1.04 \\
\hline 625.562 & Max WS & $25-\mathrm{yr}$ & 05Мay2014 1236 & 13.16 & 250.47 & 251.7 & 1.1 & 12.01 & 16.59 & 1.23 \\
\hline 625.562 & Max WS & $50-\mathrm{yr}$ & 05Мay2014 1236 & 15.22 & 250.47 & 251.77 & 1.15 & 13.29 & 17.53 & 1.3 \\
\hline 625.562 & Max WS & $100-\mathrm{yr}$ & 05May2014 1236 & 18.78 & 250.47 & 251.88 & 1.23 & 15.28 & 19.03 & 1.41 \\
\hline 625.562 & Max WS & $500-y r$ & 05May2014 1230 & 27.83 & 250.47 & 252.12 & 1.4 & 20.33 & 23.49 & 1.65 \\
\hline 582.64 & Max WS & $2-y r$ & 05May2014 1254 & 2.98 & 250.01 & 250.45 & 1.61 & 1.86 & 8.47 & 0.44 \\
\hline 582.64 & Max WS & $5-\mathrm{yr}$ & 05May2014 1242 & 5.94 & 250.01 & 250.56 & 2.06 & 2.89 & 9.78 & 0.55 \\
\hline 582.64 & Max WS & $10-y r$ & 05Мау2014 1242 & 9.13 & 250.01 & 250.68 & 2.24 & 4.07 & 11.2 & 0.67 \\
\hline 582.64 & Max WS & $25-\mathrm{yr}$ & 05Мay2014 1236 & 13.12 & 250.01 & 250.78 & 2.43 & 5.4 & 13.2 & 0.77 \\
\hline 582.64 & Max WS & $50-\mathrm{yr}$ & 05May2014 1236 & 15.19 & 250.01 & 250.81 & 2.62 & 5.8 & 13.76 & 0.8 \\
\hline 582.64 & Max WS & $100-\mathrm{yr}$ & 05May2014 1236 & 18.78 & 250.01 & 250.87 & 2.86 & 6.57 & 14.75 & 0.86 \\
\hline 582.64 & Max WS & $500-\mathrm{yr}$ & 05Мay2014 1230 & 27.69 & 250.01 & 250.99 & 3.25 & 8.68 & 18.42 & 0.98 \\
\hline 543.04 & Max WS & $2-y r$ & 05Мау2014 1254 & 2.98 & 249.4 & 249.93 & 0.64 & 4.65 & 14.71 & 0.53 \\
\hline
\end{tabular}




\begin{tabular}{|c|c|c|c|c|c|c|c|c|c|c|}
\hline $\begin{array}{l}\text { River } \\
\text { Sta }\end{array}$ & Profile & Plan & Time at Max & $\begin{array}{c}\mathbf{Q} \\
\text { Total } \\
\left(\mathrm{m}^{3} / \mathbf{s}\right)\end{array}$ & $\begin{array}{c}\text { Min } \\
\text { Ch El } \\
(\mathbf{m})\end{array}$ & $\begin{array}{l}\text { W.S. } \\
\text { Elev } \\
(\mathbf{m})\end{array}$ & $\begin{array}{c}\text { Vel } \\
\text { Chnl } \\
(\mathbf{m} / \mathbf{s}) \\
\end{array}$ & $\begin{array}{c}\text { Flow } \\
\text { Area } \\
\left(\mathbf{m}^{2}\right) \\
\end{array}$ & $\begin{array}{c}\text { Top } \\
\text { Width } \\
\text { (m) } \\
\end{array}$ & $\begin{array}{c}\text { Max Ch } \\
\text { Dpth } \\
\text { (m) }\end{array}$ \\
\hline 543.04 & Max WS & $5-\mathrm{yr}$ & 05May2014 1242 & 5.92 & 249.4 & 250.06 & 0.9 & 6.6 & 16.73 & 0.66 \\
\hline 543.04 & Max WS & $10-\mathrm{yr}$ & 05May2014 1242 & 9.11 & 249.4 & 250.22 & 0.96 & 9.52 & 19.24 & 0.82 \\
\hline 543.04 & Max WS & $25-\mathrm{yr}$ & 05May2014 1236 & 13.09 & 249.4 & 250.29 & 1.2 & 11.02 & 20.44 & 0.89 \\
\hline 543.04 & Max WS & $50-y r$ & 05Маy2014 1236 & 15.18 & 249.4 & 250.33 & 1.32 & 11.68 & 20.92 & 0.93 \\
\hline 543.04 & Max WS & $100-\mathrm{yr}$ & 05May2014 1230 & 18.63 & 249.4 & 250.38 & 1.48 & 12.9 & 21.77 & 0.98 \\
\hline 543.04 & Max WS & $500-\mathrm{yr}$ & 05May2014 1230 & 27.6 & 249.4 & 250.51 & 1.81 & 15.88 & 23.64 & 1.11 \\
\hline 496.118 & Max WS & $2-\mathrm{yr}$ & 05Мay2014 1254 & 2.97 & 249.1 & 249.88 & 0.27 & 11.01 & 25.72 & 0.78 \\
\hline 496.118 & Max WS & $5-y r$ & 05May2014 1242 & 5.88 & 249.1 & 249.98 & 0.43 & 13.68 & 28.32 & 0.88 \\
\hline 496.118 & Max WS & $10-\mathrm{yr}$ & 05May2014 1242 & 9.06 & 249.1 & 250.16 & 0.47 & 19.2 & 33.43 & 1.06 \\
\hline 496.118 & Max WS & $25-\mathrm{yr}$ & 05May2014 1236 & 13.05 & 249.1 & 250.21 & 0.62 & 21.23 & 35.14 & 1.11 \\
\hline 496.118 & Max WS & $50-\mathrm{yr}$ & 05May2014 1230 & 14.4 & 249.1 & 250.24 & 0.66 & 22.15 & 35.89 & 1.14 \\
\hline 496.118 & Max WS & $100-\mathrm{yr}$ & 05May2014 1230 & 18.51 & 249.1 & 250.28 & 0.79 & 23.73 & 36.96 & 1.18 \\
\hline 496.118 & Max WS & $500-\mathrm{yr}$ & 05May2014 1230 & 27.46 & 249.1 & 250.4 & 1 & 28.35 & 40.12 & 1.3 \\
\hline 428.594 & Max WS & $2-\mathrm{yr}$ & 05May2014 1254 & 2.95 & 248.79 & 249.03 & 1.72 & 1.72 & 13.07 & 0.24 \\
\hline 428.594 & Max WS & $5-y r$ & 05May2014 1248 & 5.85 & 248.79 & 249.14 & 1.68 & 3.48 & 18.63 & 0.35 \\
\hline 428.594 & Max WS & $10-\mathrm{yr}$ & 05May2014 1242 & 8.99 & 248.79 & 249.24 & 1.61 & 5.66 & 23.85 & 0.45 \\
\hline 428.594 & Max WS & $25-\mathrm{yr}$ & 05May2014 1236 & 12.96 & 248.79 & 249.3 & 1.91 & 6.98 & 26.05 & 0.51 \\
\hline 428.594 & Max WS & $50-y r$ & 05Мay2014 1236 & 15.16 & 248.79 & 249.33 & 2.02 & 7.79 & 27.3 & 0.54 \\
\hline 428.594 & Max WS & $100-\mathrm{yr}$ & 05Мay2014 1236 & 18.79 & 248.79 & 249.38 & 2.15 & 9.2 & 29.2 & 0.59 \\
\hline 428.594 & Max WS & $500-\mathrm{yr}$ & 05May2014 1236 & 27.15 & 248.79 & 249.49 & 2.28 & 12.84 & 33.94 & 0.7 \\
\hline 389.142 & Max WS & $2-y r$ & 05May2014 1300 & 2.92 & 248.21 & 248.5 & 0.98 & 3.69 & 27.03 & 0.29 \\
\hline 389.142 & Max WS & $5-y r$ & 05May2014 1248 & 5.83 & 248.21 & 248.66 & 0.82 & 8.31 & 32.3 & 0.45 \\
\hline 389.142 & Max WS & $10-\mathrm{yr}$ & 05May2014 1242 & 8.94 & 248.21 & 248.75 & 0.89 & 11.44 & 35.12 & 0.54 \\
\hline 389.142 & Max WS & $25-\mathrm{yr}$ & 05May2014 1242 & 12.61 & 248.21 & 248.86 & 0.94 & 15.4 & 37.95 & 0.65 \\
\hline 389.142 & Max WS & $50-\mathrm{yr}$ & 05 May2014 1236 & 15.04 & 248.21 & 248.92 & 0.98 & 17.63 & 39.32 & 0.71 \\
\hline 389.142 & Max WS & $100-\mathrm{yr}$ & 05May2014 1236 & 18.71 & 248.21 & 249.01 & 1.03 & 21.16 & 41.48 & 0.8 \\
\hline 389.142 & Max WS & $500-\mathrm{yr}$ & 05Мay2014 1236 & 27.11 & 248.21 & 249.17 & 1.12 & 28.45 & 45.24 & 0.96 \\
\hline 343.978 & Max WS & $2-y r$ & 05May2014 1300 & 2.9 & 247.75 & 248.17 & 0.65 & 4.45 & 15.64 & 0.42 \\
\hline 343.978 & Max WS & $5-y r$ & 05May2014 1248 & 5.77 & 247.75 & 248.32 & 0.83 & 6.98 & 18.89 & 0.57 \\
\hline 343.978 & Max WS & $10-y r$ & 05Мay2014 1248 & 8.72 & 247.75 & 248.45 & 0.92 & 9.58 & 22.01 & 0.7 \\
\hline 343.978 & Max WS & $25-\mathrm{yr}$ & 05May2014 1242 & 12.59 & 247.75 & 248.57 & 1.03 & 12.53 & 25.11 & 0.82 \\
\hline 343.978 & Max WS & $50-\mathrm{yr}$ & 05May2014 1236 & 14.7 & 247.75 & 248.62 & 1.11 & 13.74 & 26.18 & 0.87 \\
\hline 343.978 & Max WS & $100-\mathrm{yr}$ & 05May2014 1236 & 18.46 & 247.75 & 248.71 & 1.2 & 16.16 & 28.26 & 0.96 \\
\hline 343.978 & Max WS & $500-y r$ & 05Мay2014 1236 & 26.96 & 247.75 & 248.88 & 1.35 & 21.51 & 32.41 & 1.13 \\
\hline 318.111 & Max WS & $2-\mathrm{yr}$ & 05May2014 1300 & 2.9 & 247.65 & 248.06 & 0.79 & 3.66 & 13.95 & 0.41 \\
\hline
\end{tabular}




\begin{tabular}{|c|c|c|c|c|c|c|c|c|c|c|}
\hline $\begin{array}{l}\text { River } \\
\text { Sta }\end{array}$ & Profile & Plan & Time at Max & $\begin{array}{c}\mathbf{Q} \\
\text { Total } \\
\left(\mathrm{m}^{3} / \mathbf{s}\right) \\
\end{array}$ & $\begin{array}{c}\text { Min } \\
\text { Ch El } \\
\text { (m) }\end{array}$ & $\begin{array}{l}\text { W.S. } \\
\text { Elev } \\
(\mathbf{m})\end{array}$ & $\begin{array}{c}\text { Vel } \\
\text { Chnl } \\
(\mathbf{m} / \mathbf{s}) \\
\end{array}$ & $\begin{array}{l}\text { Flow } \\
\text { Area } \\
\left(\mathbf{m}^{2}\right) \\
\end{array}$ & $\begin{array}{c}\text { Top } \\
\text { Width } \\
\text { (m) }\end{array}$ & $\begin{array}{c}\text { Max Chl } \\
\text { Dpth } \\
\text { (m) }\end{array}$ \\
\hline 318.111 & Max WS & $5-y r$ & 05Мау2014 1248 & 5.75 & 247.65 & 248.2 & 0.98 & 5.87 & 16.99 & 0.55 \\
\hline 318.111 & Max WS & $10-\mathrm{yr}$ & 05Мay2014 1248 & 8.72 & 247.65 & 248.33 & 1.05 & 8.3 & 20.19 & 0.68 \\
\hline 318.111 & Max WS & $25-\mathrm{yr}$ & 05Мay2014 1242 & 12.58 & 247.65 & 248.45 & 1.17 & 10.86 & 22.84 & 0.8 \\
\hline 318.111 & Max WS & $50-y r$ & 05Мay2014 1236 & 14.61 & 247.65 & 248.49 & 1.25 & 11.89 & 23.81 & 0.84 \\
\hline 318.111 & Max WS & $100-\mathrm{yr}$ & 05Мay2014 1236 & 18.39 & 247.65 & 248.58 & 1.35 & 14.1 & 25.79 & 0.93 \\
\hline 318.111 & Max WS & $500-\mathrm{yr}$ & 05Мay2014 1236 & 26.92 & 247.65 & 248.75 & 1.52 & 18.81 & 29.6 & 1.1 \\
\hline 284.899 & Max WS & $2-y r$ & 05Мау2014 1300 & 2.89 & 247.49 & 247.92 & 0.68 & 4.23 & 15.27 & 0.43 \\
\hline 284.899 & Max WS & $5-y r$ & 05Мay2014 1248 & 5.73 & 247.49 & 248.06 & 0.87 & 6.57 & 18.58 & 0.57 \\
\hline 284.899 & Max WS & $10-y r$ & 05Мay2014 1248 & 8.71 & 247.49 & 248.2 & 0.92 & 9.46 & 22.22 & 0.71 \\
\hline 284.899 & Max WS & $25-\mathrm{yr}$ & 05Мay2014 1242 & 12.56 & 247.49 & 248.32 & 1.01 & 12.4 & 25.04 & 0.83 \\
\hline 284.899 & Max WS & $50-\mathrm{yr}$ & 05Мay2014 1236 & 14.49 & 247.49 & 248.37 & 1.07 & 13.55 & 26.01 & 0.88 \\
\hline 284.899 & Max WS & $100-\mathrm{yr}$ & 05May2014 1236 & 18.29 & 247.49 & 248.46 & 1.14 & 16.15 & 28.08 & 0.97 \\
\hline 284.899 & Max WS & $500-y r$ & 05Мay2014 1236 & 26.86 & 247.49 & 248.64 & 1.28 & 21.57 & 32.2 & 1.15 \\
\hline 244.681 & Max WS & $2-y r$ & 05Мay2014 1300 & 2.87 & 247.05 & 247.46 & 1.01 & 2.85 & 11.22 & 0.41 \\
\hline 244.681 & Max WS & $5-\mathrm{yr}$ & 05Мay2014 1254 & 5.64 & 247.05 & 247.63 & 1.14 & 4.95 & 13.98 & 0.58 \\
\hline 244.681 & Max WS & $10-y r$ & 05Мay2014 1248 & 8.69 & 247.05 & 247.76 & 1.25 & 6.93 & 16.55 & 0.71 \\
\hline 244.681 & Max WS & $25-\mathrm{yr}$ & 05Мay2014 1242 & 12.49 & 247.05 & 247.88 & 1.38 & 9.04 & 18.89 & 0.83 \\
\hline 244.681 & Max WS & $50-y r$ & 05Мay2014 1242 & 14.49 & 247.05 & 247.95 & 1.39 & 10.41 & 20.38 & 0.9 \\
\hline 244.681 & Max WS & $100-y r$ & 05Мay2014 1242 & 17.8 & 247.05 & 248.04 & 1.43 & 12.43 & 22.47 & 0.99 \\
\hline 244.681 & Max WS & $500-y r$ & 05May2014 1236 & 26.69 & 247.05 & 248.2 & 1.64 & 16.24 & 26.17 & 1.15 \\
\hline 214.499 & Max WS & $2-y r$ & 05Мay2014 1306 & 2.85 & 246.61 & 247.36 & 0.32 & 8.99 & 20.13 & 0.75 \\
\hline 214.499 & Max WS & $5-y r$ & 05Мay2014 1254 & 5.63 & 246.61 & 247.56 & 0.42 & 13.37 & 24.49 & 0.95 \\
\hline 214.499 & Max WS & $10-y r$ & 05Мay2014 1248 & 8.67 & 246.61 & 247.69 & 0.52 & 16.79 & 27.46 & 1.08 \\
\hline 214.499 & Max WS & $25-\mathrm{yr}$ & 05Мay2014 1242 & 12.43 & 246.61 & 247.82 & 0.63 & 20.45 & 30.16 & 1.21 \\
\hline 214.499 & Max WS & $50-\mathrm{yr}$ & 05Мay2014 1242 & 14.44 & 246.61 & 247.9 & 0.66 & 22.9 & 31.84 & 1.29 \\
\hline 214.499 & Max WS & $100-\mathrm{yr}$ & 05May2014 1242 & 17.79 & 246.61 & 247.99 & 0.72 & 26.14 & 34.14 & 1.38 \\
\hline 214.499 & Max WS & $500-\mathrm{yr}$ & 05May2014 1236 & 26.58 & 246.61 & 248.16 & 0.9 & 32.01 & 38.04 & 1.55 \\
\hline 214.498 & Max WS & $2-y r$ & 05Мay2014 1306 & 2.85 & 246.61 & 246.94 & 1.18 & 2.43 & 11.51 & 0.33 \\
\hline 214.498 & Max WS & $5-\mathrm{yr}$ & 05Мay2014 1254 & 5.6 & 246.61 & 247.09 & 1.28 & 4.37 & 14.36 & 0.48 \\
\hline 214.498 & Max WS & $10-\mathrm{yr}$ & 05Мay2014 1248 & 8.62 & 246.61 & 247.18 & 1.52 & 5.68 & 16.18 & 0.57 \\
\hline 214.498 & Max WS & $25-\mathrm{yr}$ & 05Мay2014 1242 & 12.29 & 246.61 & 247.29 & 1.63 & 7.56 & 18.55 & 0.68 \\
\hline 214.498 & Max WS & $50-y r$ & 05Мay2014 1242 & 14.33 & 246.61 & 247.34 & 1.68 & 8.53 & 19.61 & 0.73 \\
\hline 214.498 & Max WS & $100-y r$ & 05Мay2014 1242 & 17.77 & 246.61 & 247.4 & 1.81 & 9.83 & 21.05 & 0.79 \\
\hline 214.498 & Max WS & $500-\mathrm{yr}$ & 05Мay2014 1236 & 26.37 & 246.61 & 247.53 & 2.06 & 12.81 & 23.96 & 0.92 \\
\hline 147.881 & Max WS & $2-y r$ & 05Мау2014 1306 & 2.85 & 245.82 & 246.16 & 1.26 & 2.26 & 11.14 & 0.34 \\
\hline
\end{tabular}




\begin{tabular}{|c|c|c|c|c|c|c|c|c|c|c|}
\hline $\begin{array}{l}\text { River } \\
\text { Sta }\end{array}$ & Profile & Plan & Time at Max & $\begin{array}{c}\mathbf{Q} \\
\text { Total } \\
\left(\mathrm{m}^{3} / \mathbf{s}\right) \\
\end{array}$ & $\begin{array}{c}\text { Min } \\
\text { Ch El } \\
(\mathbf{m})\end{array}$ & $\begin{array}{l}\text { W.S. } \\
\text { Elev } \\
(\mathbf{m})\end{array}$ & $\begin{array}{l}\text { Vel } \\
\text { Chnl } \\
(\mathbf{m} / \mathbf{s}) \\
\end{array}$ & $\begin{array}{l}\text { Flow } \\
\text { Area } \\
\left(\mathbf{m}^{2}\right) \\
\end{array}$ & $\begin{array}{c}\text { Top } \\
\text { Width } \\
(\mathbf{m}) \\
\end{array}$ & $\begin{array}{c}\text { Max Chl } \\
\text { Dpth } \\
\text { (m) }\end{array}$ \\
\hline 147.881 & Max WS & $5-y r$ & 05May2014 1254 & 5.59 & 245.82 & 246.32 & 1.29 & 4.34 & 14.17 & 0.5 \\
\hline 147.881 & Max WS & $10-y r$ & 05May2014 1248 & 8.57 & 245.82 & 246.43 & 1.42 & 6.02 & 16.37 & 0.61 \\
\hline 147.881 & Max WS & $25-\mathrm{yr}$ & 05Мay2014 1242 & 12.17 & 245.82 & 246.57 & 1.44 & 8.45 & 19.14 & 0.75 \\
\hline 147.881 & Max WS & $50-y r$ & 05May2014 1242 & 14.25 & 245.82 & 246.63 & 1.49 & 9.59 & 20.41 & 0.81 \\
\hline 147.881 & Max WS & $100-\mathrm{yr}$ & 05 May2014 1242 & 17.73 & 245.82 & 246.72 & 1.54 & 11.53 & 22.28 & 0.9 \\
\hline 147.881 & Max WS & $500-\mathrm{yr}$ & 05 May2014 1236 & 26.16 & 245.82 & 246.91 & 1.6 & 16.34 & 26.4 & 1.09 \\
\hline 79.942 & Max WS & $2-\mathrm{yr}$ & 05Мay2014 1306 & 2.84 & 245.12 & 245.64 & 0.78 & 3.62 & 10.85 & 0.52 \\
\hline 79.942 & Max WS & $5-\mathrm{yr}$ & 05May2014 1254 & 5.55 & 245.12 & 245.85 & 0.91 & 6.08 & 13.42 & 0.73 \\
\hline 79.942 & Max WS & $10-y r$ & 05May2014 1248 & 8.5 & 245.12 & 246 & 1.03 & 8.26 & 15.42 & 0.88 \\
\hline 79.942 & Max WS & $25-\mathrm{yr}$ & 05May2014 1248 & 11.99 & 245.12 & 246.16 & 1.09 & 10.96 & 17.57 & 1.04 \\
\hline 79.942 & Max WS & $50-\mathrm{yr}$ & 05May2014 1242 & 14.1 & 245.12 & 246.24 & 1.14 & 12.38 & 18.64 & 1.12 \\
\hline 79.942 & Max WS & $100-\mathrm{yr}$ & 05May2014 1242 & 17.66 & 245.12 & 246.36 & 1.2 & 14.76 & 20.52 & 1.24 \\
\hline 79.942 & Max WS & $500-\mathrm{yr}$ & 05Мay2014 1236 & 25.81 & 245.12 & 246.6 & 1.29 & 20.11 & 24.06 & 1.48 \\
\hline 53.415 & Max WS & $2-\mathrm{yr}$ & 05May2014 1306 & 2.83 & 244.76 & 245.11 & 1.89 & 1.5 & 6.5 & 0.35 \\
\hline 53.415 & Max WS & $5-\mathrm{yr}$ & 05May2014 1254 & 5.53 & 244.76 & 245.26 & 2.13 & 2.6 & 7.96 & 0.5 \\
\hline 53.415 & Max WS & $10-\mathrm{yr}$ & 05May2014 1248 & 8.48 & 244.76 & 245.37 & 2.45 & 3.47 & 8.91 & 0.61 \\
\hline 53.415 & Max WS & $25-\mathrm{yr}$ & 05May2014 1248 & 11.99 & 244.76 & 245.48 & 2.62 & 4.58 & 9.92 & 0.72 \\
\hline 53.415 & Max WS & $50-\mathrm{yr}$ & 05May2014 1242 & 14.05 & 244.76 & 245.54 & 2.72 & 5.17 & 10.41 & 0.78 \\
\hline 53.415 & Max WS & $100-\mathrm{yr}$ & 05May2014 1242 & 17.63 & 244.76 & 245.62 & 2.96 & 5.96 & 11.04 & 0.86 \\
\hline 53.415 & Max WS & $500-y r$ & 05May2014 1236 & 25.71 & 244.76 & 245.78 & 3.28 & 7.84 & 12.4 & 1.02 \\
\hline 13.63 & Max WS & $2-\mathrm{yr}$ & 05May2014 1306 & 2.83 & 243.93 & 244.34 & 1.32 & 2.14 & 7.68 & 0.41 \\
\hline 13.63 & Max WS & $5-y r$ & 05May2014 1254 & 5.52 & 243.93 & 244.49 & 1.6 & 3.45 & 9.06 & 0.56 \\
\hline 13.63 & Max WS & $10-\mathrm{yr}$ & 05May2014 1248 & 8.46 & 243.93 & 244.62 & 1.8 & 4.69 & 10.15 & 0.69 \\
\hline 13.63 & Max WS & $25-y r$ & 05May2014 1248 & 11.99 & 243.93 & 244.75 & 1.98 & 6.05 & 11.24 & 0.82 \\
\hline 13.63 & Max WS & $50-\mathrm{yr}$ & 05May2014 1242 & 14 & 243.93 & 244.81 & 2.07 & 6.76 & 11.77 & 0.88 \\
\hline 13.63 & Max WS & $100-\mathrm{yr}$ & 05May2014 1242 & 17.61 & 243.93 & 244.91 & 2.2 & 7.99 & 12.63 & 0.98 \\
\hline 13.63 & Max WS & $500-y r$ & 05May2014 1242 & 25.65 & 243.93 & 245.1 & 2.43 & 10.56 & 14.39 & 1.17 \\
\hline
\end{tabular}

Table 25: Unsteady Conventional cross-sectional properties

\begin{tabular}{|c|c|c|c|c|c|c|c|c|c|c|}
\hline $\begin{array}{l}\text { River } \\
\text { Sta }\end{array}$ & Profile & Plan & Time at Max & $\begin{array}{c}\mathbf{Q} \\
\text { Total } \\
\left(\mathrm{m}^{3} / \mathbf{s}\right)\end{array}$ & $\begin{array}{c}\text { Min } \\
\text { Ch El } \\
\text { (m) }\end{array}$ & $\begin{array}{l}\text { W.S. } \\
\text { Elev } \\
(\mathbf{m})\end{array}$ & $\begin{array}{l}\text { Vel } \\
\text { Chnl } \\
(\mathbf{m} / \mathbf{s})\end{array}$ & $\begin{array}{l}\text { Flow } \\
\text { Area } \\
\left(\mathbf{m}^{2}\right)\end{array}$ & $\begin{array}{c}\text { Top } \\
\text { Width } \\
\text { (m) }\end{array}$ & $\begin{array}{c}\text { Max Chl } \\
\text { Dpth } \\
\text { (m) }\end{array}$ \\
\hline 2097.011 & Max WS & $2-y r$ & 05Мау2014 1236 & 1.66 & 264.87 & 265.52 & 0.48 & 3.5 & 8.05 & 0.65 \\
\hline 2097.011 & Max WS & $5-\mathrm{yr}$ & 05May2014 1236 & 1.43 & 264.87 & 269.11 & 0.01 & 131 & 74.38 & 4.24 \\
\hline 2097.011 & Max WS & $10-\mathrm{yr}$ & 05Мау2014 1212 & 12.96 & 264.87 & 266.39 & 1 & 12.93 & 13.45 & 1.52 \\
\hline 2097.011 & Max WS & $25-\mathrm{yr}$ & 05Мay2014 1206 & 23.13 & 264.87 & 266.85 & 1.17 & 19.73 & 16.31 & 1.98 \\
\hline 2097.011 & Max WS & $50-\mathrm{yr}$ & 05May2014 1206 & 27.41 & 264.87 & 267.02 & 1.21 & 22.62 & 19.22 & 2.15 \\
\hline
\end{tabular}




\begin{tabular}{|c|c|c|c|c|c|c|c|c|c|c|}
\hline $\begin{array}{l}\text { River } \\
\text { Sta }\end{array}$ & Profile & Plan & Time at Max & $\begin{array}{c}\mathbf{Q} \\
\text { Total } \\
\left(\mathbf{m}^{3} / \mathbf{s}\right) \\
\end{array}$ & $\begin{array}{c}\text { Min } \\
\text { Ch El } \\
\text { (m) }\end{array}$ & $\begin{array}{l}\text { W.S. } \\
\text { Elev } \\
(\mathbf{m})\end{array}$ & $\begin{array}{l}\text { Vel } \\
\text { Chnl } \\
(\mathbf{m} / \mathbf{s}) \\
\end{array}$ & $\begin{array}{l}\text { Flow } \\
\text { Area } \\
\left(\mathbf{m}^{2}\right)\end{array}$ & $\begin{array}{c}\text { Top } \\
\text { Width } \\
(\mathbf{m})\end{array}$ & $\begin{array}{c}\text { Max Chl } \\
\text { Dpth } \\
\text { (m) }\end{array}$ \\
\hline 2097.011 & Max WS & $100-\mathrm{yr}$ & 05Мay2014 1206 & 32 & 264.87 & 267.2 & 1.23 & 27.18 & 28.96 & 2.33 \\
\hline 2097.011 & Max WS & $500-\mathrm{yr}$ & 05Мау2014 1200 & 45.47 & 264.87 & 267.55 & 1.31 & 39.78 & 42.5 & 2.68 \\
\hline 2052.742 & Max WS & $2-\mathrm{yr}$ & 05Мау2014 1236 & 1.65 & 264.51 & 264.83 & 1.79 & 0.92 & 5.02 & 0.32 \\
\hline 2052.742 & Max WS & $5-\mathrm{yr}$ & 05Мay2014 1236 & 0.66 & 264.51 & 266.86 & 0.03 & 24.03 & 18.03 & 2.35 \\
\hline 2052.742 & Max WS & $10-\mathrm{yr}$ & 05May2014 1212 & 12.22 & 264.51 & 265.3 & 2.92 & 4.19 & 8.54 & 0.79 \\
\hline 2052.742 & Max WS & $25-\mathrm{yr}$ & 05Мay2014 1206 & 21.73 & 264.51 & 265.5 & 3.66 & 5.93 & 9.54 & 0.99 \\
\hline 2052.742 & Max WS & $50-\mathrm{yr}$ & 05May2014 1206 & 25.53 & 264.51 & 265.56 & 3.88 & 6.58 & 9.88 & 1.05 \\
\hline 2052.742 & Max WS & $100-\mathrm{yr}$ & 05May2014 1206 & 31.37 & 264.51 & 265.65 & 4.21 & 7.45 & 10.32 & 1.14 \\
\hline 2052.742 & Max WS & $500-\mathrm{yr}$ & 05Маy2014 1200 & 42.86 & 264.51 & 265.78 & 4.84 & 8.86 & 10.99 & 1.27 \\
\hline 2009.086 & Max WS & $2-\mathrm{yr}$ & 05Мay2014 1236 & 1.64 & 263.84 & 264.1 & 1.12 & 1.46 & 8.21 & 0.26 \\
\hline 2009.086 & Max WS & $5-\mathrm{yr}$ & 05Мay2014 1236 & 0.73 & 263.84 & 265.83 & 0.02 & 30.94 & 25.22 & 1.99 \\
\hline 2009.086 & Max WS & $10-\mathrm{yr}$ & 05May2014 1212 & 11.65 & 263.84 & 264.62 & 1.59 & 7.31 & 13.98 & 0.78 \\
\hline 2009.086 & Max WS & $25-y r$ & 05Мay2014 1206 & 20.78 & 263.84 & 264.89 & 1.81 & 11.5 & 16.66 & 1.05 \\
\hline 2009.086 & Max WS & $50-\mathrm{yr}$ & 05May2014 1206 & 24.4 & 263.84 & 264.98 & 1.89 & 12.94 & 17.43 & 1.14 \\
\hline 2009.086 & Max WS & $100-\mathrm{yr}$ & 05May2014 1206 & 31.11 & 263.84 & 265.09 & 2.07 & 15.03 & 18.49 & 1.25 \\
\hline 2009.086 & Max WS & $500-\mathrm{yr}$ & 05Мay2014 1200 & 41.91 & 263.84 & 265.32 & 2.19 & 19.33 & 20.45 & 1.48 \\
\hline 1964.49 & Max WS & $2-\mathrm{yr}$ & 05Мay2014 1236 & 1.63 & 263.35 & 263.59 & 1.18 & 1.38 & 8.87 & 0.24 \\
\hline 1964.49 & Max WS & $5-\mathrm{yr}$ & 05May2014 1236 & 1.09 & 263.35 & 266.39 & 0.01 & 107.9 & 81.25 & 3.04 \\
\hline 1964.49 & Max WS & $10-\mathrm{yr}$ & 05May2014 1212 & 10.99 & 263.35 & 263.95 & 1.94 & 5.66 & 14.44 & 0.6 \\
\hline 1964.49 & Max WS & $25-\mathrm{yr}$ & 05Мay2014 1212 & 19.03 & 263.35 & 264.14 & 2.2 & 8.65 & 17.43 & 0.79 \\
\hline 1964.49 & Max WS & $50-\mathrm{yr}$ & 05Мay2014 1206 & 22.98 & 263.35 & 264.17 & 2.49 & 9.24 & 18 & 0.82 \\
\hline 1964.49 & Max WS & $100-\mathrm{yr}$ & 05May2014 1206 & 30.73 & 263.35 & 264.3 & 2.62 & 11.73 & 20.1 & 0.95 \\
\hline 1964.49 & Max WS & $500-\mathrm{yr}$ & 05May2014 1206 & 41.3 & 263.35 & 264.45 & 2.79 & 14.81 & 22.49 & 1.1 \\
\hline 1925.761 & Max WS & $2-y r$ & 05Мay2014 1242 & 1.61 & 263.04 & 263.25 & 0.77 & 2.09 & 14.76 & 0.21 \\
\hline 1925.761 & Max WS & $5-y r$ & 05May2014 1242 & 1.45 & 263.04 & 265.04 & 0.02 & 109.16 & 108.44 & 2 \\
\hline 1925.761 & Max WS & $10-y r$ & 05Мay2014 1218 & 10.42 & 263.04 & 263.65 & 1 & 10.54 & 29.98 & 0.61 \\
\hline 1925.761 & Max WS & $25-\mathrm{yr}$ & 05Мay2014 1212 & 18.86 & 263.04 & 263.86 & 1.13 & 18.06 & 40.06 & 0.82 \\
\hline 1925.761 & Max WS & $50-\mathrm{yr}$ & 05Мay2014 1212 & 20.83 & 263.04 & 263.91 & 1.14 & 20.09 & 42.12 & 0.87 \\
\hline 1925.761 & Max WS & $100-\mathrm{yr}$ & 05May2014 1206 & 29.97 & 263.04 & 264.05 & 1.29 & 26.37 & 48.44 & 1.01 \\
\hline 1925.761 & Max WS & $500-\mathrm{yr}$ & 05May2014 1206 & 40.92 & 263.04 & 264.24 & 1.34 & 36.59 & 61.85 & 1.2 \\
\hline 1874.546 & Max WS & $2-\mathrm{yr}$ & 05May2014 1242 & 1.61 & 262.4 & 262.86 & 0.46 & 3.53 & 13.02 & 0.46 \\
\hline 1874.546 & Max WS & $5-y r$ & 05Мау2014 1242 & 0.39 & 262.4 & 263.48 & 0.03 & 15.65 & 26.65 & 1.08 \\
\hline 1874.546 & Max WS & $10-y r$ & 05Мау2014 1218 & 10.16 & 262.4 & 263.24 & 1.02 & 10 & 21.18 & 0.84 \\
\hline 1874.546 & Max WS & $25-\mathrm{yr}$ & 05Мау2014 1212 & 18.18 & 262.4 & 263.43 & 1.26 & 14.48 & 25.57 & 1.03 \\
\hline 1874.546 & Max WS & $50-\mathrm{yr}$ & 05May2014 1212 & 20.34 & 262.4 & 263.46 & 1.34 & 15.3 & 26.3 & 1.06 \\
\hline
\end{tabular}




\begin{tabular}{|c|c|c|c|c|c|c|c|c|c|c|}
\hline $\begin{array}{l}\text { River } \\
\text { Sta }\end{array}$ & Profile & Plan & Time at Max & $\begin{array}{c}\mathbf{Q} \\
\text { Total } \\
\left(\mathrm{m}^{3} / \mathbf{s}\right)\end{array}$ & $\begin{array}{c}\text { Min } \\
\text { Ch El } \\
\text { (m) }\end{array}$ & $\begin{array}{l}\text { W.S. } \\
\text { Elev } \\
(\mathbf{m})\end{array}$ & $\begin{array}{l}\text { Vel } \\
\text { Chnl } \\
(\mathbf{m} / \mathbf{s})\end{array}$ & $\begin{array}{l}\text { Flow } \\
\text { Area } \\
\left(\mathbf{m}^{2}\right)\end{array}$ & $\begin{array}{c}\text { Top } \\
\text { Width } \\
\text { (m) }\end{array}$ & $\begin{array}{c}\text { Max Chl } \\
\text { Dpth } \\
\text { (m) }\end{array}$ \\
\hline 1874.546 & Max WS & $100-\mathrm{yr}$ & 05Мay2014 1206 & 27.6 & 262.4 & 263.56 & 1.57 & 18 & 28.99 & 1.16 \\
\hline 1874.546 & Max WS & $500-\mathrm{yr}$ & 05May2014 1206 & 39.77 & 262.4 & 263.71 & 1.84 & 22.81 & 34.04 & 1.31 \\
\hline 1828.159 & Max WS & $2-\mathrm{yr}$ & 05May2014 1242 & 1.6 & 262.13 & 262.38 & 1.35 & 1.18 & 8.38 & 0.25 \\
\hline 1828.159 & Max WS & $5-\mathrm{yr}$ & 05May2014 1242 & 0.05 & 262.13 & 263.34 & 0 & 21.73 & 34.65 & 1.21 \\
\hline 1828.159 & Max WS & $10-\mathrm{yr}$ & 05May2014 1218 & 9.99 & 262.13 & 262.76 & 1.59 & 6.28 & 18.75 & 0.63 \\
\hline 1828.159 & Max WS & $25-\mathrm{yr}$ & 05May2014 1212 & 17.85 & 262.13 & 262.94 & 1.75 & 10.19 & 23.99 & 0.81 \\
\hline 1828.159 & Max WS & $50-\mathrm{yr}$ & 05May2014 1212 & 20.12 & 262.13 & 262.98 & 1.81 & 11.14 & 24.88 & 0.85 \\
\hline 1828.159 & Max WS & $100-\mathrm{yr}$ & 05May2014 1206 & 26.76 & 262.13 & 263.08 & 1.97 & 13.72 & 27.37 & 0.95 \\
\hline 1828.159 & Max WS & $500-\mathrm{yr}$ & 05May2014 1206 & 39.36 & 262.13 & 263.26 & 2.15 & 19.07 & 32.2 & 1.13 \\
\hline 1788.723 & Max WS & $2-\mathrm{yr}$ & 05May2014 1242 & 1.59 & 261.54 & 262.06 & 0.36 & 4.46 & 15.3 & 0.52 \\
\hline 1788.723 & Max WS & $5-\mathrm{yr}$ & 05Мау2014 1242 & 0.48 & 261.54 & 262.86 & 0.02 & 25.18 & 35.25 & 1.32 \\
\hline 1788.723 & Max WS & $10-\mathrm{yr}$ & 05May2014 1218 & 9.72 & 261.54 & 262.53 & 0.67 & 14.69 & 28.09 & 0.99 \\
\hline 1788.723 & Max WS & $25-y r$ & 05Маy2014 1212 & 17.36 & 261.54 & 262.74 & 0.84 & 21.24 & 32.73 & 1.2 \\
\hline 1788.723 & Max WS & $50-\mathrm{yr}$ & 05May2014 1212 & 19.68 & 261.54 & 262.8 & 0.89 & 23.15 & 33.96 & 1.26 \\
\hline 1788.723 & Max WS & $100-\mathrm{yr}$ & 05May2014 1212 & 25.62 & 261.54 & 262.93 & 0.98 & 27.78 & 36.8 & 1.39 \\
\hline 1788.723 & Max WS & $500-\mathrm{yr}$ & 05May2014 1206 & 38.77 & 261.54 & 263.14 & 1.16 & 36 & 40.7 & 1.6 \\
\hline 1742.556 & Max WS & $2-y r$ & 05Мау2014 1242 & 1.58 & 261.5 & 262.03 & 0.33 & 4.84 & 15.29 & 0.53 \\
\hline 1742.556 & Max WS & $5-y r$ & 05May2014 1242 & 1.23 & 261.5 & 262.6 & 0.07 & 16.94 & 27.18 & 1.1 \\
\hline 1742.556 & Max WS & $10-\mathrm{yr}$ & 05May2014 1218 & 9.31 & 261.5 & 262.46 & 0.7 & 13.31 & 24.32 & 0.96 \\
\hline 1742.556 & Max WS & $25-\mathrm{yr}$ & 05Маy2014 1212 & 16.71 & 261.5 & 262.65 & 0.91 & 18.47 & & 1.15 \\
\hline 1742.556 & Max WS & $50-\mathrm{yr}$ & 05May2014 1212 & 19.06 & 261.5 & 262.71 & 0.96 & 20.06 & 29.36 & 1.21 \\
\hline 1742.556 & Max WS & $100-\mathrm{yr}$ & 05May2014 1206 & 24.16 & 261.5 & 262.83 & 1.05 & 23.64 & 31.59 & 1.33 \\
\hline 1742.556 & Max WS & $500-\mathrm{yr}$ & 05May2014 1206 & 38.03 & 261.5 & 263.02 & 1.32 & 30.2 & 35.52 & 1.52 \\
\hline 1695.655 & Max WS & $2-\mathrm{yr}$ & 05May2014 1248 & 1.57 & 261.28 & 261.55 & 1.45 & 1.08 & 6.61 & 0.27 \\
\hline 1695.655 & Max WS & $5-\mathrm{yr}$ & 05May2014 1248 & 0.55 & 261.28 & 262.01 & 0.1 & 5.71 & 13.11 & 0.73 \\
\hline 1695.655 & Max WS & $10-\mathrm{yr}$ & 05May2014 1224 & 9.08 & 261.28 & 261.99 & 1.67 & 5.42 & 12.83 & 0.71 \\
\hline 1695.655 & Max WS & $25-\mathrm{yr}$ & 05May2014 1218 & 15.34 & 261.28 & 262.21 & 1.77 & 8.66 & 16.04 & 0.93 \\
\hline 1695.655 & Max WS & $50-y r$ & 05Мay2014 1218 & 17.15 & 261.28 & 262.28 & 1.76 & 9.74 & 17.17 & 1 \\
\hline 1695.655 & Max WS & $100-\mathrm{yr}$ & 05May2014 1212 & 25.43 & 261.28 & 262.48 & 1.91 & 13.75 & 22.3 & 1.2 \\
\hline 1695.655 & Max WS & $500-\mathrm{yr}$ & 05May2014 1212 & 34.94 & 261.28 & 262.76 & 1.83 & 21.11 & 32.27 & 1.48 \\
\hline 1651.05 & Max WS & $2-y r$ & 05Мay2014 1248 & 1.57 & 260.78 & 261.15 & 0.58 & 2.69 & 11.2 & 0.37 \\
\hline 1651.05 & Max WS & $5-\mathrm{yr}$ & 05May2014 1248 & 0.88 & 260.78 & 261.88 & 0.06 & 14.07 & 19.23 & 1.1 \\
\hline 1651.05 & Max WS & $10-y r$ & 05Мay2014 1224 & 8.99 & 260.78 & 261.75 & 0.77 & 11.68 & 18.03 & 0.97 \\
\hline 1651.05 & Max WS & $25-\mathrm{yr}$ & 05May2014 1218 & 15.24 & 260.78 & 262.06 & 0.86 & 17.74 & 20.88 & 1.28 \\
\hline 1651.05 & Max WS & $50-\mathrm{yr}$ & 05May2014 1218 & 17.07 & 260.78 & 262.14 & 0.88 & 19.44 & 21.56 & 1.36 \\
\hline
\end{tabular}




\begin{tabular}{|c|c|c|c|c|c|c|c|c|c|c|}
\hline $\begin{array}{l}\text { River } \\
\text { Sta }\end{array}$ & Profile & Plan & Time at Max & $\begin{array}{c}\mathbf{Q} \\
\text { Total } \\
\left(\mathbf{m}^{3} / \mathbf{s}\right)\end{array}$ & $\begin{array}{l}\text { Min } \\
\text { Ch El } \\
\text { (m) }\end{array}$ & $\begin{array}{l}\text { W.S. } \\
\text { Elev } \\
(\mathbf{m})\end{array}$ & $\begin{array}{l}\text { Vel } \\
\text { Chnl } \\
(\mathbf{m} / \mathbf{s})\end{array}$ & $\begin{array}{l}\text { Flow } \\
\text { Area } \\
\left(\mathbf{m}^{2}\right)\end{array}$ & $\begin{array}{c}\text { Top } \\
\text { Width } \\
\text { (m) }\end{array}$ & $\begin{array}{c}\text { Max Chl } \\
\text { Dpth } \\
\text { (m) }\end{array}$ \\
\hline 1651.05 & Max WS & $100-\mathrm{yr}$ & 05Мау2014 1212 & 24.98 & 260.78 & 262.39 & 1 & 25.08 & 23.71 & 1.61 \\
\hline 1651.05 & Max WS & $500-y r$ & 05Мay2014 1212 & 34.74 & 260.78 & 262.7 & 1.06 & 32.91 & 26.6 & 1.92 \\
\hline 1617.21 & Max WS & $2-\mathrm{yr}$ & 05Мау2014 1248 & 1.56 & 260.56 & 261.08 & 0.5 & 3.11 & 9.65 & 0.52 \\
\hline 1617.21 & Max WS & $5-\mathrm{yr}$ & 05Мау2014 1248 & 0.24 & 260.56 & 261.56 & 0.03 & 8.74 & 14.01 & 1 \\
\hline 1617.21 & Max WS & $10-\mathrm{yr}$ & 05Мay2014 1224 & 8.87 & 260.56 & 261.69 & 0.83 & 10.63 & 15.26 & 1.13 \\
\hline 1617.21 & Max WS & $25-\mathrm{yr}$ & 05Маy2014 1218 & 15.11 & 260.56 & 262 & 0.96 & 15.81 & 17.98 & 1.44 \\
\hline 1617.21 & Max WS & $50-\mathrm{yr}$ & 05Маy2014 1218 & 16.96 & 260.56 & 262.08 & 0.98 & 17.3 & 18.68 & 1.52 \\
\hline 1617.21 & Max WS & $100-\mathrm{yr}$ & 05Мay2014 1212 & 24.56 & 260.56 & 262.32 & 1.11 & 22.04 & 20.5 & 1.76 \\
\hline 1617.21 & Max WS & $500-\mathrm{yr}$ & 05Мay2014 1212 & 34.6 & 260.56 & 262.63 & 1.2 & 28.75 & 22.56 & 2.07 \\
\hline 1577.381 & Max WS & $2-y r$ & 05Мау2014 1248 & 1.54 & 260.48 & 261.06 & 0.14 & 11.18 & 24.58 & 0.58 \\
\hline 1577.381 & Max WS & $5-\mathrm{yr}$ & 05Мау2014 1248 & 0 & 260.48 & 261.13 & 0 & 12.99 & 25.46 & 0.65 \\
\hline 1577.381 & Max WS & $10-\mathrm{yr}$ & 05Маy2014 1224 & 8.65 & 260.48 & 261.67 & 0.3 & 28.41 & 31.15 & 1.19 \\
\hline 1577.381 & Max WS & $25-\mathrm{yr}$ & 05Мау2014 1218 & 14.87 & 260.48 & 261.99 & 0.38 & 38.85 & 34.27 & 1.51 \\
\hline 1577.381 & Max WS & $50-\mathrm{yr}$ & 05Маy2014 1218 & 16.75 & 260.48 & 262.07 & 0.4 & 41.73 & 34.83 & 1.59 \\
\hline 1577.381 & Max WS & $100-\mathrm{yr}$ & 05Мау2014 1212 & 23.87 & 260.48 & 262.32 & 0.47 & 50.85 & 39.62 & 1.84 \\
\hline 1577.381 & Max WS & $500-\mathrm{yr}$ & 05Мау2014 1212 & 34.33 & 260.48 & 262.64 & 0.55 & 65.47 & 52.55 & 2.16 \\
\hline 1542.946 & Max WS & $2-\mathrm{yr}$ & 05Маy2014 1254 & 1.52 & 260.49 & 260.97 & 0.8 & 1.89 & 5.42 & 0.48 \\
\hline 1542.946 & Max WS & $5-y r$ & 05Мay2014 1248 & 0.47 & 260.49 & 261.01 & 0.22 & 2.13 & 5.61 & 0.52 \\
\hline 1542.946 & Max WS & $10-\mathrm{yr}$ & 05Мау2014 1224 & 8.49 & 260.49 & 261.48 & 1.62 & 5.24 & 7.77 & 0.99 \\
\hline 1542.946 & Max WS & $25-\mathrm{yr}$ & 05Маy2014 1218 & 14.71 & 260.49 & 261.75 & 1.96 & 7.5 & 9.05 & 1.26 \\
\hline 1542.946 & Max WS & $50-\mathrm{yr}$ & 05Мау2014 1218 & 16.61 & 260.49 & 261.81 & 2.05 & 8.11 & 9.36 & 1.32 \\
\hline 1542.946 & Max WS & $100-\mathrm{yr}$ & 05Мау2014 1212 & 23.37 & 260.49 & 262.02 & 2.29 & 10.2 & 10.26 & 1.53 \\
\hline 1542.946 & Max WS & $500-\mathrm{yr}$ & 05Мау2014 1212 & 34.14 & 260.49 & 262.3 & 2.61 & 13.1 & 11.14 & 1.81 \\
\hline 1504.079 & Max WS & $2-\mathrm{yr}$ & 05Маy2014 1254 & 1.52 & 260.31 & 260.72 & 0.97 & 1.56 & 6.48 & 0.41 \\
\hline 1504.079 & Max WS & $5-\mathrm{yr}$ & 05Мay2014 1248 & 0.56 & 260.31 & 261.4 & 0.07 & 7.42 & 10.17 & 1.09 \\
\hline 1504.079 & Max WS & $10-\mathrm{yr}$ & 05Мay2014 1224 & 8.42 & 260.31 & 261.19 & 1.56 & 5.4 & 9.22 & 0.88 \\
\hline 1504.079 & Max WS & $25-\mathrm{yr}$ & 05May2014 1218 & 14.63 & 260.31 & 261.44 & 1.88 & 7.79 & 10.33 & 1.13 \\
\hline 1504.079 & Max WS & $50-\mathrm{yr}$ & 05Маy2014 1218 & 16.54 & 260.31 & 261.5 & 1.96 & 8.43 & 10.61 & 1.19 \\
\hline 1504.079 & Max WS & $100-y r$ & 05May2014 1212 & 23.16 & 260.31 & 261.68 & 2.23 & 10.38 & 11.42 & 1.37 \\
\hline 1504.079 & Max WS & $500-\mathrm{yr}$ & 05Мау2014 1212 & 34.07 & 260.31 & 261.88 & 2.65 & 12.84 & 12.36 & 1.57 \\
\hline 1467.659 & Max WS & $2-\mathrm{yr}$ & 05Маy2014 1254 & 1.52 & 260.12 & 260.51 & 0.74 & 2.06 & 7.84 & 0.39 \\
\hline 1467.659 & Max WS & $5-\mathrm{yr}$ & 05Мay2014 1248 & 0.44 & 260.12 & 260.85 & 0.09 & 5.12 & 10.26 & 0.73 \\
\hline 1467.659 & Max WS & $10-\mathrm{yr}$ & 05Маy2014 1224 & 8.32 & 260.12 & 261.03 & 1.18 & 7.05 & 11.56 & 0.91 \\
\hline 1467.659 & Max WS & $25-\mathrm{yr}$ & 05May2014 1218 & 14.53 & 260.12 & 261.27 & 1.45 & 10.03 & 13.54 & 1.15 \\
\hline 1467.659 & Max WS & $50-\mathrm{yr}$ & 05Мау2014 1218 & 16.44 & 260.12 & 261.33 & 1.5 & 10.98 & 14.15 & 1.21 \\
\hline
\end{tabular}




\begin{tabular}{|c|c|c|c|c|c|c|c|c|c|c|}
\hline $\begin{array}{l}\text { River } \\
\text { Sta }\end{array}$ & Profile & Plan & Time at Max & $\begin{array}{c}\mathbf{Q} \\
\text { Total } \\
\left(\mathbf{m}^{3} / \mathbf{s}\right) \\
\end{array}$ & $\begin{array}{c}\text { Min } \\
\text { Ch El } \\
\text { (m) }\end{array}$ & $\begin{array}{l}\text { W.S. } \\
\text { Elev } \\
(\mathbf{m})\end{array}$ & $\begin{array}{l}\text { Vel } \\
\text { Chnl } \\
(\mathbf{m} / \mathbf{s}) \\
\end{array}$ & $\begin{array}{l}\text { Flow } \\
\text { Area } \\
\left(\mathbf{m}^{2}\right)\end{array}$ & $\begin{array}{c}\text { Top } \\
\text { Width } \\
\text { (m) }\end{array}$ & $\begin{array}{c}\text { Max Chl } \\
\text { Dpth } \\
\text { (m) }\end{array}$ \\
\hline 1467.659 & Max WS & $100-\mathrm{yr}$ & 05Мay2014 1212 & 22.94 & 260.12 & 261.49 & 1.72 & 13.34 & 15.6 & 1.37 \\
\hline 1467.659 & Max WS & $500-\mathrm{yr}$ & 05Мау2014 1212 & 33.99 & 260.12 & 261.71 & 2 & 17.03 & 17.85 & 1.59 \\
\hline 1425.307 & Max WS & $2-y r$ & 05Маy2014 1254 & 1.52 & 259.66 & 260 & 1.44 & 1.05 & 5.48 & 0.34 \\
\hline 1425.307 & Max WS & $5-\mathrm{yr}$ & 05Мay2014 1254 & 0.32 & 259.66 & 260.3 & 0.1 & 3.09 & 8.05 & 0.64 \\
\hline 1425.307 & Max WS & $10-\mathrm{yr}$ & 05May2014 1224 & 8.21 & 259.66 & 260.42 & 2 & 4.11 & 9.05 & 0.76 \\
\hline 1425.307 & Max WS & $25-\mathrm{yr}$ & 05Мay2014 1218 & 14.4 & 259.66 & 260.63 & 2.31 & 6.22 & 10.99 & 0.97 \\
\hline 1425.307 & Max WS & $50-\mathrm{yr}$ & 05May2014 1218 & 16.31 & 259.66 & 260.69 & 2.35 & 6.94 & 11.67 & 1.03 \\
\hline 1425.307 & Max WS & $100-\mathrm{yr}$ & 05May2014 1212 & 22.65 & 259.66 & 260.85 & 2.55 & 8.87 & 13.34 & 1.19 \\
\hline 1425.307 & Max WS & $500-\mathrm{yr}$ & 05Мау2014 1212 & 33.86 & 259.66 & 261.08 & 2.8 & 12.34 & 18.33 & 1.42 \\
\hline 1392.843 & Max WS & $2-\mathrm{yr}$ & 05Мay2014 1254 & 1.51 & 259.14 & 259.51 & 1.28 & 1.18 & 5.78 & 0.37 \\
\hline 1392.843 & Max WS & $5-\mathrm{yr}$ & 05Мау2014 1248 & -0.02 & 259.14 & 259.79 & -0.01 & 3.19 & 8.46 & 0.65 \\
\hline 1392.843 & Max WS & $10-\mathrm{yr}$ & 05May2014 1224 & 8.13 & 259.14 & 259.94 & 1.8 & 4.53 & 9.35 & 0.8 \\
\hline 1392.843 & Max WS & $25-y r$ & 05Мay2014 1218 & 14.31 & 259.14 & 260.16 & 2.14 & 6.68 & 10.55 & 1.02 \\
\hline 1392.843 & Max WS & $50-y r$ & 05Мay2014 1218 & 16.22 & 259.14 & 260.22 & 2.19 & 7.39 & 10.91 & 1.08 \\
\hline 1392.843 & Max WS & $100-\mathrm{yr}$ & 05May2014 1212 & 22.43 & 259.14 & 260.39 & 2.41 & 9.31 & 11.94 & 1.25 \\
\hline 1392.843 & Max WS & $500-\mathrm{yr}$ & 05Мay2014 1212 & 33.74 & 259.14 & 260.67 & 2.58 & 13.07 & 14.75 & 1.53 \\
\hline 1358.799 & Max WS & $2-\mathrm{yr}$ & 05Мay2014 1254 & 1.51 & 258.63 & 258.96 & 1.48 & 1.02 & 5.56 & 0.33 \\
\hline 1358.799 & Max WS & $5-\mathrm{yr}$ & 05May2014 1254 & 0.13 & 258.63 & 259.5 & 0.03 & 5.28 & 9.62 & 0.87 \\
\hline 1358.799 & Max WS & $10-\mathrm{yr}$ & 05May2014 1230 & 8.06 & 258.63 & 259.36 & 2 & 4.03 & 8.81 & 0.73 \\
\hline 1358.799 & Max WS & $25-\mathrm{yr}$ & 05May2014 1218 & 14.22 & 258.63 & 259.57 & 2.4 & 5.93 & 10.02 & 0.94 \\
\hline 1358.799 & Max WS & $50-\mathrm{yr}$ & 05May2014 1218 & 16.12 & 258.63 & 259.62 & 2.49 & 6.48 & 10.34 & 0.99 \\
\hline 1358.799 & Max WS & $100-\mathrm{yr}$ & 05May2014 1212 & 22.22 & 258.63 & 259.77 & 2.73 & 8.14 & 11.28 & 1.14 \\
\hline 1358.799 & Max WS & $500-\mathrm{yr}$ & 05May2014 1212 & 33.6 & 258.63 & 260.02 & 3.02 & 11.12 & 12.82 & 1.39 \\
\hline 1329.439 & Max WS & $2-y r$ & 05Мay2014 1254 & 1.51 & 258.21 & 258.57 & 1.14 & 1.32 & 6.31 & 0.36 \\
\hline 1329.439 & Max WS & $5-\mathrm{yr}$ & 05May2014 1248 & 0.09 & 258.21 & 259.51 & 0.01 & 10.45 & 12.6 & 1.3 \\
\hline 1329.439 & Max WS & $10-y r$ & 05Мay2014 1230 & 8.06 & 258.21 & 259.01 & 1.66 & 4.86 & 9.55 & 0.8 \\
\hline 1329.439 & Max WS & $25-\mathrm{yr}$ & 05Мay2014 1218 & 14.13 & 258.21 & 259.26 & 1.9 & 7.44 & 11.07 & 1.05 \\
\hline 1329.439 & Max WS & $50-\mathrm{yr}$ & 05Мay2014 1218 & 16.02 & 258.21 & 259.32 & 1.96 & 8.19 & 11.47 & 1.11 \\
\hline 1329.439 & Max WS & $100-\mathrm{yr}$ & 05May2014 1218 & 21.6 & 258.21 & 259.51 & 2.07 & 10.45 & 12.6 & 1.3 \\
\hline 1329.439 & Max WS & $500-\mathrm{yr}$ & 05May2014 1212 & 33.47 & 258.21 & 259.84 & 2.25 & 14.94 & 14.51 & 1.63 \\
\hline 1302.462 & Max WS & $2-\mathrm{yr}$ & 05Мay2014 1254 & 1.5 & 257.76 & 258.45 & 0.27 & 5.54 & 11.66 & 0.69 \\
\hline 1302.462 & Max WS & $5-y r$ & 05Мау2014 1242 & 0.02 & 257.76 & 259.51 & 0 & 21.4 & 18.5 & 1.75 \\
\hline 1302.462 & Max WS & $10-\mathrm{yr}$ & 05Маy2014 1230 & 8.06 & 257.76 & 258.94 & 0.67 & 11.98 & 14.72 & 1.18 \\
\hline 1302.462 & Max WS & $25-\mathrm{yr}$ & 05Мау2014 1218 & 13.98 & 257.76 & 259.23 & 0.85 & 16.5 & 16.61 & 1.47 \\
\hline 1302.462 & Max WS & $50-\mathrm{yr}$ & 05May2014 1218 & 15.86 & 257.76 & 259.31 & 0.89 & 17.79 & 17.12 & 1.55 \\
\hline
\end{tabular}




\begin{tabular}{|c|c|c|c|c|c|c|c|c|c|c|}
\hline $\begin{array}{l}\text { River } \\
\text { Sta }\end{array}$ & Profile & Plan & Time at Max & $\begin{array}{c}\mathbf{Q} \\
\text { Total } \\
\left(\mathrm{m}^{3} / \mathbf{s}\right)\end{array}$ & $\begin{array}{c}\text { Min } \\
\text { Ch El } \\
(\mathbf{m})\end{array}$ & $\begin{array}{l}\text { W.S. } \\
\text { Elev } \\
(\mathbf{m})\end{array}$ & $\begin{array}{l}\text { Vel } \\
\text { Chnl } \\
(\mathbf{m} / \mathbf{s})\end{array}$ & $\begin{array}{l}\text { Flow } \\
\text { Area } \\
\left(\mathbf{m}^{2}\right)\end{array}$ & $\begin{array}{c}\text { Top } \\
\text { Width } \\
\text { (m) }\end{array}$ & $\begin{array}{c}\text { Max Chl } \\
\text { Dpth } \\
\text { (m) }\end{array}$ \\
\hline 1302.462 & Max WS & $100-\mathrm{yr}$ & 05Мay2014 1218 & 21.6 & 257.76 & 259.52 & 1 & 21.54 & 18.55 & 1.76 \\
\hline 1302.462 & Max WS & $500-\mathrm{yr}$ & 05May2014 1212 & 33.29 & 257.76 & 259.89 & 1.15 & 28.88 & 21.29 & 2.13 \\
\hline 1264.23 & Max WS & $2-\mathrm{yr}$ & 05May2014 1300 & 1.49 & 257.59 & 257.95 & 1.23 & 1.21 & 5.77 & 0.36 \\
\hline 1264.23 & Max WS & $5-\mathrm{yr}$ & 05May2014 1254 & 1.91 & 257.59 & 258.2 & 0.66 & 2.89 & 7.65 & 0.61 \\
\hline 1264.23 & Max WS & $10-\mathrm{yr}$ & 05May2014 1230 & 8.03 & 257.59 & 258.42 & 1.71 & 4.7 & 9.03 & 0.83 \\
\hline 1264.23 & Max WS & $25-\mathrm{yr}$ & 05Мay2014 1224 & 13.43 & 257.59 & 258.63 & 1.99 & 6.74 & 10.08 & 1.04 \\
\hline 1264.23 & Max WS & $50-\mathrm{yr}$ & 05May2014 1218 & 15.43 & 257.59 & 258.68 & 2.12 & 7.28 & 10.34 & 1.09 \\
\hline 1264.23 & Max WS & $100-\mathrm{yr}$ & 05May2014 1218 & 21.55 & 257.59 & 258.86 & 2.34 & 9.2 & 11.22 & 1.27 \\
\hline 1264.23 & Max WS & $500-\mathrm{yr}$ & 05May2014 1212 & 32.82 & 257.59 & 259.08 & 2.79 & 11.76 & 12.3 & 1.49 \\
\hline 1230.005 & Max WS & $2-\mathrm{yr}$ & 05Мay2014 1300 & 1.49 & 257.24 & 257.75 & 0.53 & 2.79 & 7.9 & 0.51 \\
\hline 1230.005 & Max WS & $5-\mathrm{yr}$ & 05Мay2014 1254 & 0.09 & 257.24 & 258.14 & 0.01 & 6.39 & 10.57 & 0.9 \\
\hline 1230.005 & Max WS & $10-\mathrm{yr}$ & 05May2014 1230 & 7.99 & 257.24 & 258.27 & 1.02 & 7.81 & 11.39 & 1.03 \\
\hline 1230.005 & Max WS & $25-y r$ & 05Маy2014 1224 & 13.41 & 257.24 & 258.5 & 1.27 & 10.54 & 12.81 & 1.26 \\
\hline 1230.005 & Max WS & $50-\mathrm{yr}$ & 05May2014 1224 & 14.99 & 257.24 & 258.55 & 1.33 & 11.26 & 13.16 & 1.31 \\
\hline 1230.005 & Max WS & $100-\mathrm{yr}$ & 05May2014 1218 & 21.49 & 257.24 & 258.74 & 1.55 & 13.89 & 14.23 & 1.5 \\
\hline 1230.005 & Max WS & $500-\mathrm{yr}$ & 05May2014 1212 & 32.62 & 257.24 & 258.96 & 1.91 & 17.05 & 15.37 & 1.72 \\
\hline 1191.977 & Max WS & $2-y r$ & 05Мау2014 1300 & 1.48 & 256.91 & 257.69 & 0.25 & 5.95 & 11.26 & 0.78 \\
\hline 1191.977 & Max WS & $5-\mathrm{yr}$ & 05May2014 1254 & 1.05 & 256.91 & 257.98 & 0.11 & 9.38 & 13.12 & 1.07 \\
\hline 1191.977 & Max WS & $10-\mathrm{yr}$ & 05May2014 1230 & 7.88 & 256.91 & 258.16 & 0.66 & 11.94 & 14.29 & 1.25 \\
\hline 1191.977 & Max WS & $25-\mathrm{yr}$ & 05Маy2014 1224 & 13.34 & 256.91 & 258.36 & 0.9 & 14.89 & 15.63 & 1.45 \\
\hline 1191.977 & Max WS & $50-\mathrm{yr}$ & 05May2014 1224 & 14.94 & 256.91 & 258.41 & 0.96 & 15.63 & 15.95 & 1.5 \\
\hline 1191.977 & Max WS & $100-\mathrm{yr}$ & 05May2014 1218 & 21.3 & 256.91 & 258.57 & 1.15 & 19.43 & 29.32 & 1.66 \\
\hline 1191.977 & Max WS & $500-\mathrm{yr}$ & 05May2014 1218 & 30.37 & 256.91 & 258.79 & 1.29 & 27.37 & 48.83 & 1.88 \\
\hline 1155.309 & Max WS & $2-\mathrm{yr}$ & 05May2014 1300 & 1.48 & 257.11 & 257.66 & 0.5 & 2.98 & 7.81 & 0.55 \\
\hline 1155.309 & Max WS & $5-\mathrm{yr}$ & 05May2014 1254 & 0.17 & 257.11 & 257.66 & 0.06 & 2.95 & 7.78 & 0.55 \\
\hline 1155.309 & Max WS & $10-\mathrm{yr}$ & 05May2014 1230 & 7.8 & 257.11 & 258.07 & 1.05 & 8.6 & 25.03 & 0.96 \\
\hline 1155.309 & Max WS & $25-\mathrm{yr}$ & 05May2014 1224 & 13.27 & 257.11 & 258.28 & 1.13 & 14.28 & 30.99 & 1.17 \\
\hline 1155.309 & Max WS & $50-y r$ & 05Мay2014 1224 & 14.89 & 257.11 & 258.33 & 1.15 & 15.95 & 35.27 & 1.22 \\
\hline 1155.309 & Max WS & $100-\mathrm{yr}$ & 05May2014 1218 & 21.09 & 257.11 & 258.51 & 1.14 & 23.49 & 44.33 & 1.4 \\
\hline 1155.309 & Max WS & $500-\mathrm{yr}$ & 05May2014 1218 & 30.36 & 257.11 & 258.74 & 1.07 & 34.4 & 48.46 & 1.63 \\
\hline 1124.025 & Max WS & $2-y r$ & 05Мay2014 1300 & 1.48 & 255.94 & 256.24 & 2.17 & 0.68 & 4.65 & 0.3 \\
\hline 1124.025 & Max WS & $5-\mathrm{yr}$ & 05May2014 1300 & 0.17 & 255.94 & 256.28 & 0.19 & 0.88 & 5.28 & 0.34 \\
\hline 1124.025 & Max WS & $10-y r$ & 05Мay2014 1230 & 7.68 & 255.94 & 256.59 & 2.59 & 2.97 & 7.54 & 0.65 \\
\hline 1124.025 & Max WS & $25-\mathrm{yr}$ & 05May2014 1224 & 13.15 & 255.94 & 256.78 & 2.96 & 4.44 & 8.33 & 0.84 \\
\hline 1124.025 & Max WS & $50-\mathrm{yr}$ & 05May2014 1224 & 14.79 & 255.94 & 256.82 & 3.08 & 4.81 & 8.51 & 0.88 \\
\hline
\end{tabular}




\begin{tabular}{|c|c|c|c|c|c|c|c|c|c|c|}
\hline $\begin{array}{l}\text { River } \\
\text { Sta }\end{array}$ & Profile & Plan & Time at Max & $\begin{array}{c}\mathbf{Q} \\
\text { Total } \\
\left(\mathbf{m}^{3} / \mathbf{s}\right) \\
\end{array}$ & $\begin{array}{c}\text { Min } \\
\text { Ch El } \\
\text { (m) }\end{array}$ & $\begin{array}{l}\text { W.S. } \\
\text { Elev } \\
(\mathbf{m})\end{array}$ & $\begin{array}{c}\text { Vel } \\
\text { Chnl } \\
(\mathbf{m} / \mathbf{s}) \\
\end{array}$ & $\begin{array}{l}\text { Flow } \\
\text { Area } \\
\left(\mathbf{m}^{2}\right) \\
\end{array}$ & $\begin{array}{c}\text { Top } \\
\text { Width } \\
(\mathbf{m}) \\
\end{array}$ & $\begin{array}{c}\text { Max Chl } \\
\text { Dpth } \\
\text { (m) }\end{array}$ \\
\hline 1124.025 & Max WS & $100-\mathrm{yr}$ & 05May2014 1218 & 20.72 & 255.94 & 256.98 & 3.35 & 6.19 & 9.18 & 1.04 \\
\hline 1124.025 & Max WS & $500-y r$ & 05May2014 1218 & 30.33 & 255.94 & 257.17 & 3.77 & 8.04 & 9.96 & 1.23 \\
\hline 1083.982 & Max WS & $2-y r$ & 05Мау2014 1306 & 1.47 & 255 & 255.6 & 0.5 & 2.92 & 7.29 & 0.6 \\
\hline 1083.982 & Max WS & $5-\mathrm{yr}$ & 05Мay2014 1300 & 1.1 & 255 & 255.52 & 0.46 & 2.36 & 6.76 & 0.52 \\
\hline 1083.982 & Max WS & $10-y r$ & 05Мау2014 1230 & 7.62 & 255 & 256.11 & 1.04 & 7.3 & 9.68 & 1.11 \\
\hline 1083.982 & Max WS & $25-y r$ & 05Мay2014 1224 & 13.08 & 255 & 256.38 & 1.29 & 10.13 & 10.81 & 1.38 \\
\hline 1083.982 & Max WS & $50-y r$ & 05May2014 1224 & 14.74 & 255 & 256.45 & 1.36 & 10.86 & 11.08 & 1.45 \\
\hline 1083.982 & Max WS & $100-\mathrm{yr}$ & 05Мay2014 1218 & 20.6 & 255 & 256.67 & 1.54 & 13.39 & 11.99 & 1.67 \\
\hline 1083.982 & Max WS & $500-y r$ & 05Мay2014 1218 & 30.3 & 255 & 256.96 & 1.78 & 17.04 & 13.2 & 1.96 \\
\hline 1018.257 & Max WS & $2-\mathrm{yr}$ & 05Мay2014 1306 & 1.47 & 254.8 & 255.21 & 1.03 & 1.42 & 5.92 & 0.41 \\
\hline 1018.257 & Max WS & $5-y r$ & 05Мау2014 1300 & 1.1 & 254.8 & 255.13 & 1.1 & 1 & 5.09 & 0.33 \\
\hline 1018.257 & Max WS & $10-y r$ & 05Мay2014 1236 & 7.49 & 254.8 & 255.64 & 1.61 & 4.64 & 8.67 & 0.84 \\
\hline 1018.257 & Max WS & $25-y r$ & 05Маy2014 1224 & 12.92 & 254.8 & 255.87 & 1.9 & 6.79 & 9.57 & 1.07 \\
\hline 1018.257 & Max WS & $50-y r$ & 05Мау2014 1224 & 14.63 & 254.8 & 255.93 & 1.99 & 7.36 & 9.8 & 1.13 \\
\hline 1018.257 & Max WS & $100-y r$ & 05Мау2014 1218 & 20.34 & 254.8 & 256.11 & 2.21 & 9.2 & 10.49 & 1.31 \\
\hline 1018.257 & Max WS & $500-\mathrm{yr}$ & 05Мау2014 1218 & 30.19 & 254.8 & 256.38 & 2.49 & 12.19 & 15.3 & 1.58 \\
\hline 959.582 & Max WS & $2-y r$ & 05Мay2014 1306 & 1.47 & 254.42 & 254.88 & 0.6 & 2.46 & 7.87 & 0.46 \\
\hline 959.582 & Max WS & $5-\mathrm{yr}$ & 05Мay2014 1300 & 0.05 & 254.42 & 254.81 & 0.03 & 1.87 & 7.25 & 0.39 \\
\hline 959.582 & Max WS & $10-y r$ & 05Маy2014 1236 & 7.48 & 254.42 & 255.29 & 1.2 & 6.22 & 10.56 & 0.87 \\
\hline 959.582 & Max WS & $25-\mathrm{yr}$ & 05Маy2014 1224 & 12.76 & 254.42 & 255.54 & 1.41 & 9.02 & 11.81 & 1.12 \\
\hline 959.582 & Max WS & $50-\mathrm{yr}$ & 05Мay2014 1224 & 14.5 & 254.42 & 255.6 & 1.48 & 9.82 & 12.1 & 1.18 \\
\hline 959.582 & Max WS & $100-y r$ & 05Мay2014 1218 & 19.99 & 254.42 & 255.8 & 1.63 & 12.28 & 12.95 & 1.38 \\
\hline 959.582 & Max WS & $500-y r$ & 05May2014 1218 & 29.95 & 254.42 & 256.11 & 1.78 & 17.92 & 26.14 & 1.69 \\
\hline 917.744 & Max WS & $2-\mathrm{yr}$ & 05May2014 1306 & 1.46 & 253.94 & 254.36 & 1.03 & 1.41 & 6.38 & 0.42 \\
\hline 917.744 & Max WS & $5-\mathrm{yr}$ & 05May2014 1300 & 0 & 253.94 & 254.33 & 0 & 1.21 & 6.03 & 0.39 \\
\hline 917.744 & Max WS & $10-\mathrm{yr}$ & 05May2014 1236 & 7.45 & 253.94 & 254.83 & 1.45 & 5.15 & 9.21 & 0.89 \\
\hline 917.744 & Max WS & $25-\mathrm{yr}$ & 05May2014 1224 & 12.53 & 253.94 & 255.08 & 1.65 & 7.61 & 10.44 & 1.14 \\
\hline 917.744 & Max WS & $50-\mathrm{yr}$ & 05May2014 1224 & 14.28 & 253.94 & 255.16 & 1.7 & 8.4 & 10.79 & 1.22 \\
\hline 917.744 & Max WS & $100-\mathrm{yr}$ & 05May2014 1218 & 19.48 & 253.94 & 255.35 & 1.84 & 10.59 & 11.68 & 1.41 \\
\hline 917.744 & Max WS & $500-y r$ & 05May2014 1218 & 29.58 & 253.94 & 255.68 & 2.02 & 14.65 & 13.1 & 1.74 \\
\hline 885.843 & Max WS & $2-\mathrm{yr}$ & 05Мay2014 1306 & 1.46 & 253.61 & 254.11 & 0.91 & 1.6 & 5.36 & 0.5 \\
\hline 885.843 & Max WS & $5-\mathrm{yr}$ & 05Мay2014 1300 & 0.98 & 253.61 & 254.06 & 0.73 & 1.35 & 5.1 & 0.45 \\
\hline 885.843 & Max WS & $10-y r$ & 05Мау2014 1236 & 7.44 & 253.61 & 254.55 & 1.63 & 4.58 & 7.92 & 0.94 \\
\hline 885.843 & Max WS & $25-\mathrm{yr}$ & 05May2014 1224 & 12.44 & 253.61 & 254.81 & 1.82 & 6.82 & 9.42 & 1.2 \\
\hline 885.843 & Max WS & $50-\mathrm{yr}$ & 05Мау2014 1224 & 14.19 & 253.61 & 254.88 & 1.91 & 7.43 & 9.72 & 1.27 \\
\hline
\end{tabular}




\begin{tabular}{|c|c|c|c|c|c|c|c|c|c|c|}
\hline $\begin{array}{l}\text { River } \\
\text { Sta }\end{array}$ & Profile & Plan & Time at Max & $\begin{array}{c}Q \\
\text { Total } \\
\left(\mathbf{m}^{3} / \mathbf{s}\right)\end{array}$ & $\begin{array}{c}\text { Min } \\
\text { Ch El } \\
\text { (m) }\end{array}$ & $\begin{array}{l}\text { W.S. } \\
\text { Elev } \\
(\mathbf{m})\end{array}$ & $\begin{array}{c}\text { Vel } \\
\text { Chnl } \\
(\mathbf{m} / \mathbf{s})\end{array}$ & $\begin{array}{l}\text { Flow } \\
\text { Area } \\
\left(\mathbf{m}^{2}\right) \\
\end{array}$ & $\begin{array}{c}\text { Top } \\
\text { Width } \\
\text { (m) } \\
\end{array}$ & $\begin{array}{c}\text { Max Chl } \\
\text { Dpth } \\
(\mathbf{m})\end{array}$ \\
\hline 885.843 & Max WS & $100-\mathrm{yr}$ & 05Мay2014 1218 & 19.31 & 253.61 & 255.09 & 2.01 & 9.61 & 10.56 & 1.48 \\
\hline 885.843 & Max WS & $500-\mathrm{yr}$ & 05Маy2014 1218 & 29.48 & 253.61 & 255.44 & 2.19 & 13.45 & 11.74 & 1.83 \\
\hline 831.018 & Max WS & $2-y r$ & 05Мау2014 1306 & 1.46 & 252.63 & 252.87 & 1.9 & 0.77 & 4.85 & 0.24 \\
\hline 831.018 & Max WS & $5-\mathrm{yr}$ & 05Мау2014 1300 & 1.11 & 252.63 & 252.83 & 1.9 & 0.58 & 4.59 & 0.2 \\
\hline 831.018 & Max WS & $10-\mathrm{yr}$ & 05Маy2014 1236 & 7.42 & 252.63 & 253.22 & 2.64 & 2.81 & 6.85 & 0.59 \\
\hline 831.018 & Max WS & $25-\mathrm{yr}$ & 05Мay2014 1230 & 12.28 & 252.63 & 253.4 & 2.95 & 4.17 & 7.8 & 0.77 \\
\hline 831.018 & Max WS & $50-\mathrm{yr}$ & 05Мау2014 1224 & 14.07 & 252.63 & 253.44 & 3.12 & 4.52 & 8.03 & 0.81 \\
\hline 831.018 & Max WS & $100-\mathrm{yr}$ & 05Мау2014 1224 & 19.3 & 252.63 & 253.58 & 3.44 & 5.62 & 8.71 & 0.95 \\
\hline 831.018 & Max WS & $500-\mathrm{yr}$ & 05Мay2014 1218 & 29.36 & 252.63 & 253.78 & 3.92 & 7.48 & 9.73 & 1.15 \\
\hline 794.448 & Max WS & $2-y r$ & 05Маy2014 1306 & 1.45 & 251.86 & 252.25 & 0.79 & 1.83 & 6.44 & 0.39 \\
\hline 794.448 & Max WS & $5-y r$ & 05Мay2014 1306 & 1.11 & 251.86 & 252.17 & 0.83 & 1.34 & 5.8 & 0.31 \\
\hline 794.448 & Max WS & $10-\mathrm{yr}$ & 05Мау2014 1236 & 7.4 & 251.86 & 252.76 & 1.25 & 5.94 & 9.7 & 0.9 \\
\hline 794.448 & Max WS & $25-y r$ & 05Мay2014 1230 & 12.27 & 251.86 & 253 & 1.45 & 8.47 & 11.21 & 1.14 \\
\hline 794.448 & Max WS & $50-\mathrm{yr}$ & 05Мау2014 1224 & 13.95 & 251.86 & 253.07 & 1.51 & 9.24 & 11.63 & 1.21 \\
\hline 794.448 & Max WS & $100-\mathrm{yr}$ & 05Мау2014 1224 & 19.27 & 251.86 & 253.26 & 1.66 & 11.62 & 12.81 & 1.4 \\
\hline 794.448 & Max WS & $500-\mathrm{yr}$ & 05Мау2014 1218 & 29.25 & 251.86 & 253.55 & 1.88 & 15.55 & 14.26 & 1.69 \\
\hline 753.27 & Max WS & $2-y r$ & 05Мау2014 1306 & 1.45 & 251.5 & 251.9 & 1.14 & 1.27 & 5.27 & 0.4 \\
\hline 753.27 & Max WS & $5-y r$ & 05Мay2014 1300 & -0.1 & 251.5 & 251.88 & -0.08 & 1.18 & 5.11 & 0.38 \\
\hline 753.27 & Max WS & $10-\mathrm{yr}$ & 05May2014 1236 & 7.37 & 251.5 & 252.3 & 1.79 & 4.11 & 8.57 & 0.8 \\
\hline 753.27 & Max WS & $25-\mathrm{yr}$ & 05May2014 1230 & 12.26 & 251.5 & 252.48 & 2.17 & 5.66 & 9.42 & 0.98 \\
\hline 753.27 & Max WS & $50-\mathrm{yr}$ & 05Мау2014 1224 & 13.82 & 251.5 & 252.53 & 2.22 & 6.21 & 9.7 & 1.03 \\
\hline 753.27 & Max WS & $100-\mathrm{yr}$ & 05Мау2014 1218 & 18.7 & 251.5 & 252.68 & 2.42 & 7.73 & 10.42 & 1.18 \\
\hline 753.27 & Max WS & $500-\mathrm{yr}$ & 05Мау2014 1218 & 29.12 & 251.5 & 252.92 & 2.81 & 10.36 & 11.5 & 1.42 \\
\hline 720.714 & Max WS & $2-y r$ & 05May2014 1312 & 1.45 & 251.09 & 251.41 & 1.47 & 0.99 & 5.76 & 0.32 \\
\hline 720.714 & Max WS & $5-\mathrm{yr}$ & 05Мay2014 1306 & 0.04 & 251.09 & 251.47 & 0.03 & 1.37 & 6.27 & 0.38 \\
\hline 720.714 & Max WS & $10-y r$ & 05Мay2014 1236 & 7.34 & 251.09 & 251.81 & 1.88 & 3.91 & 8.77 & 0.72 \\
\hline 720.714 & Max WS & $25-y r$ & 05Мay2014 1230 & 12.25 & 251.09 & 252 & 2.15 & 5.69 & 9.93 & 0.91 \\
\hline 720.714 & Max WS & $50-\mathrm{yr}$ & 05Маy2014 1230 & 13.73 & 251.09 & 252.05 & 2.2 & 6.23 & 10.24 & 0.96 \\
\hline 720.714 & Max WS & $100-\mathrm{yr}$ & 05Маy2014 1224 & 19.23 & 251.09 & 252.21 & 2.43 & 7.92 & 11.14 & 1.12 \\
\hline 720.714 & Max WS & $500-\mathrm{yr}$ & 05Маy2014 1218 & 29.02 & 251.09 & 252.43 & 2.78 & 10.45 & 12.37 & 1.34 \\
\hline 673.556 & Max WS & $2-\mathrm{yr}$ & 05Маy2014 1312 & 1.45 & 250.52 & 251.04 & 0.29 & 4.96 & 14.33 & 0.52 \\
\hline 673.556 & Max WS & $5-\mathrm{yr}$ & 05Мay2014 1306 & 1.15 & 250.52 & 250.98 & 0.28 & 4.18 & 13.48 & 0.46 \\
\hline 673.556 & Max WS & $10-y r$ & 05Мау2014 1236 & 7.25 & 250.52 & 251.52 & 0.53 & 13.7 & 21.67 & 1 \\
\hline 673.556 & Max WS & $25-y r$ & 05Мay2014 1230 & 12.17 & 250.52 & 251.78 & 0.62 & 19.64 & 25.61 & 1.26 \\
\hline 673.556 & Max WS & $50-\mathrm{yr}$ & 05May2014 1230 & 13.68 & 250.52 & 251.84 & 0.64 & 21.37 & 26.7 & 1.32 \\
\hline
\end{tabular}




\begin{tabular}{|c|c|c|c|c|c|c|c|c|c|c|}
\hline $\begin{array}{l}\text { River } \\
\text { Sta }\end{array}$ & Profile & Plan & Time at Max & $\begin{array}{c}\mathbf{Q} \\
\text { Total } \\
\left(\mathbf{m}^{3} / \mathbf{s}\right) \\
\end{array}$ & $\begin{array}{c}\text { Min } \\
\text { Ch El } \\
(\mathbf{m})\end{array}$ & $\begin{array}{l}\text { W.S. } \\
\text { Elev } \\
(\mathbf{m})\end{array}$ & $\begin{array}{l}\text { Vel } \\
\text { Chnl } \\
(\mathbf{m} / \mathbf{s})\end{array}$ & $\begin{array}{l}\text { Flow } \\
\text { Area } \\
\left(\mathbf{m}^{2}\right) \\
\end{array}$ & $\begin{array}{c}\text { Top } \\
\text { Width } \\
\text { (m) }\end{array}$ & $\begin{array}{c}\text { Max Chl } \\
\text { Dpth } \\
(\mathbf{m})\end{array}$ \\
\hline 673.556 & Max WS & $100-\mathrm{yr}$ & 05Маy2014 1224 & 19.1 & 250.52 & 252.03 & 0.72 & 26.61 & 30.02 & 1.51 \\
\hline 673.556 & Max WS & $500-\mathrm{yr}$ & 05Мау2014 1218 & 28.61 & 250.52 & 252.28 & 0.82 & 34.76 & 34.38 & 1.76 \\
\hline 625.562 & Max WS & $2-\mathrm{yr}$ & 05Мay2014 1312 & 1.44 & 250.47 & 250.97 & 0.51 & 2.81 & 9.31 & 0.5 \\
\hline 625.562 & Max WS & $5-\mathrm{yr}$ & 05Мау2014 1306 & 0.98 & 250.47 & 250.93 & 0.4 & 2.43 & 8.93 & 0.46 \\
\hline 625.562 & Max WS & $10-\mathrm{yr}$ & 05May2014 1236 & 7.13 & 250.47 & 251.42 & 0.91 & 7.85 & 13.33 & 0.95 \\
\hline 625.562 & Max WS & $25-\mathrm{yr}$ & 05Мау2014 1230 & 12.05 & 250.47 & 251.65 & 1.07 & 11.3 & 16.05 & 1.18 \\
\hline 625.562 & Max WS & $50-\mathrm{yr}$ & 05May2014 1230 & 13.61 & 250.47 & 251.72 & 1.11 & 12.31 & 16.81 & 1.25 \\
\hline 625.562 & Max WS & $100-\mathrm{yr}$ & 05Мау2014 1224 & 18.91 & 250.47 & 251.88 & 1.24 & 15.28 & 19.03 & 1.41 \\
\hline 625.562 & Max WS & $500-\mathrm{yr}$ & 05Мау2014 1218 & 28.07 & 250.47 & 252.12 & 1.41 & 20.43 & 23.56 & 1.65 \\
\hline 582.64 & Max WS & $2-\mathrm{yr}$ & 05Маy2014 1312 & 1.44 & 250.01 & 250.3 & 1.82 & 0.8 & 5.6 & 0.29 \\
\hline 582.64 & Max WS & $5-\mathrm{yr}$ & 05Мау2014 1306 & 0.05 & 250.01 & 250.37 & 0.04 & 1.23 & 6.81 & 0.36 \\
\hline 582.64 & Max WS & $10-\mathrm{yr}$ & 05May2014 1242 & 7.03 & 250.01 & 250.6 & 2.14 & 3.28 & 10.23 & 0.59 \\
\hline 582.64 & Max WS & $25-\mathrm{yr}$ & 05Мay2014 1230 & 11.98 & 250.01 & 250.76 & 2.35 & 5.1 & 12.79 & 0.75 \\
\hline 582.64 & Max WS & $50-\mathrm{yr}$ & 05May2014 1230 & 13.57 & 250.01 & 250.79 & 2.47 & 5.48 & 13.32 & 0.78 \\
\hline 582.64 & Max WS & $100-\mathrm{yr}$ & 05Мау2014 1224 & 18.82 & 250.01 & 250.87 & 2.86 & 6.58 & 14.77 & 0.86 \\
\hline 582.64 & Max WS & $500-\mathrm{yr}$ & 05Мay2014 1218 & 27.82 & 250.01 & 251 & 3.25 & 8.7 & 18.46 & 0.99 \\
\hline 543.04 & Max WS & $2-\mathrm{yr}$ & 05Мау2014 1318 & 1.43 & 249.4 & 249.8 & 0.49 & 2.91 & 12.21 & 0.4 \\
\hline 543.04 & Max WS & $5-\mathrm{yr}$ & 05Мау2014 1306 & 0.98 & 249.4 & 249.73 & 0.48 & 2.04 & 10.63 & 0.33 \\
\hline 543.04 & Max WS & $10-\mathrm{yr}$ & 05Мay2014 1242 & 7.02 & 249.4 & 250.11 & 0.92 & 7.61 & 17.58 & 0.71 \\
\hline 543.04 & Max WS & $25-\mathrm{yr}$ & 05Мay2014 1230 & 11.94 & 249.4 & 250.28 & 1.13 & 10.69 & & 0.88 \\
\hline 543.04 & Max WS & $50-\mathrm{yr}$ & 05Мay2014 1230 & 13.53 & 249.4 & 250.3 & 1.22 & 11.22 & 20.59 & 0.9 \\
\hline 543.04 & Max WS & $100-y r$ & 05Маy2014 1224 & 18.76 & 249.4 & 250.39 & 1.48 & 12.96 & 21.82 & 0.99 \\
\hline 543.04 & Max WS & $500-y r$ & 05May2014 1218 & 27.65 & 249.4 & 250.52 & 1.79 & 16.05 & 23.75 & 1.12 \\
\hline 496.118 & Max WS & $2-y r$ & 05Мay2014 1318 & 1.43 & 249.1 & 249.76 & 0.18 & 8.11 & 22.35 & 0.66 \\
\hline 496.118 & Max WS & $5-\mathrm{yr}$ & 05May2014 1312 & 0.93 & 249.1 & 249.69 & 0.14 & 6.61 & 20.47 & 0.59 \\
\hline 496.118 & Max WS & $10-y r$ & 05Мay2014 1242 & 6.99 & 249.1 & 250.04 & 0.45 & 15.43 & 30.06 & 0.94 \\
\hline 496.118 & Max WS & $25-\mathrm{yr}$ & 05May2014 1230 & 11.85 & 249.1 & 250.2 & 0.57 & 20.89 & 34.86 & 1.1 \\
\hline 496.118 & Max WS & $50-y r$ & 05Мау2014 1230 & 13.47 & 249.1 & 250.22 & 0.63 & 21.58 & 35.42 & 1.12 \\
\hline 496.118 & Max WS & $100-\mathrm{yr}$ & 05Мay2014 1224 & 18.68 & 249.1 & 250.29 & 0.79 & 23.87 & 37.04 & 1.19 \\
\hline 496.118 & Max WS & $500-\mathrm{yr}$ & 05May2014 1218 & 27.38 & 249.1 & 250.42 & 0.98 & 28.83 & 40.44 & 1.32 \\
\hline 428.594 & Max WS & $2-\mathrm{yr}$ & 05Мау2014 1318 & 1.42 & 248.79 & 248.98 & 1.31 & 1.09 & 10.58 & 0.19 \\
\hline 428.594 & Max WS & $5-\mathrm{yr}$ & 05Маy2014 1312 & -0.01 & 248.79 & 249.02 & 0 & 1.6 & 12.63 & 0.23 \\
\hline 428.594 & Max WS & $10-y r$ & 05Мау2014 1242 & 6.93 & 248.79 & 249.18 & 1.66 & 4.18 & 20.43 & 0.39 \\
\hline 428.594 & Max WS & $25-\mathrm{yr}$ & 05May2014 1230 & 11.68 & 248.79 & 249.28 & 1.83 & 6.54 & 25.34 & 0.49 \\
\hline 428.594 & Max WS & $50-\mathrm{yr}$ & 05Мау2014 1230 & 13.33 & 248.79 & 249.3 & 1.93 & 7.1 & 26.24 & 0.51 \\
\hline
\end{tabular}




\begin{tabular}{|c|c|c|c|c|c|c|c|c|c|c|}
\hline $\begin{array}{l}\text { River } \\
\text { Sta }\end{array}$ & Profile & Plan & Time at Max & $\begin{array}{c}\mathbf{Q} \\
\text { Total } \\
\left(\mathbf{m}^{3} / \mathbf{s}\right) \\
\end{array}$ & $\begin{array}{c}\text { Min } \\
\text { Ch El } \\
(\mathbf{m}) \\
\end{array}$ & $\begin{array}{l}\text { W.S. } \\
\text { Elev } \\
(\mathbf{m})\end{array}$ & $\begin{array}{c}\text { Vel } \\
\text { Chnl } \\
(\mathbf{m} / \mathbf{s})\end{array}$ & $\begin{array}{c}\text { Flow } \\
\text { Area } \\
\left(\mathbf{m}^{2}\right) \\
\end{array}$ & $\begin{array}{c}\text { Top } \\
\text { Width } \\
(\mathbf{m}) \\
\end{array}$ & $\begin{array}{c}\text { Max Chl } \\
\text { Dpth } \\
(\mathbf{m})\end{array}$ \\
\hline 428.594 & Max WS & $100-y r$ & 05Мау2014 1224 & 18.49 & 248.79 & 249.37 & 2.15 & 9.01 & 28.93 & 0.58 \\
\hline 428.594 & Max WS & $500-y r$ & 05Мay2014 1224 & 27.7 & 248.79 & 249.5 & 2.29 & 13.04 & 34.17 & 0.71 \\
\hline 389.142 & Max WS & $2-y r$ & 05Мау2014 1318 & 1.42 & 248.21 & 248.41 & 1.09 & 1.51 & 17.97 & 0.2 \\
\hline 389.142 & Max WS & $5-y r$ & 05Маy2014 1312 & 0 & 248.21 & 248.41 & 0 & 1.39 & 17.05 & 0.2 \\
\hline 389.142 & Max WS & $10-y r$ & 05Мay2014 1242 & 6.88 & 248.21 & 248.69 & 0.86 & 9.33 & 33.26 & 0.48 \\
\hline 389.142 & Max WS & $25-\mathrm{yr}$ & 05Мay2014 1236 & 11.42 & 248.21 & 248.83 & 0.92 & 14.2 & 37.11 & 0.62 \\
\hline 389.142 & Max WS & $50-y r$ & 05Маy2014 1230 & 13.13 & 248.21 & 248.87 & 0.97 & 15.56 & 38.05 & 0.66 \\
\hline 389.142 & Max WS & $100-\mathrm{yr}$ & 05Маy2014 1230 & 17.82 & 248.21 & 248.99 & 1.01 & 20.5 & 41.12 & 0.78 \\
\hline 389.142 & Max WS & $500-\mathrm{yr}$ & 05Маy2014 1224 & 27.57 & 248.21 & 249.18 & 1.13 & 28.67 & 45.35 & 0.97 \\
\hline 343.978 & Max WS & $2-y r$ & 05Мay2014 1318 & 1.41 & 247.75 & 248.02 & 0.6 & 2.36 & 12.95 & 0.27 \\
\hline 343.978 & Max WS & $5-y r$ & 05Мау2014 1312 & 1.49 & 247.75 & 248.02 & 0.64 & 2.34 & 12.92 & 0.27 \\
\hline 343.978 & Max WS & $10-\mathrm{yr}$ & 05Мay2014 1242 & 6.72 & 247.75 & 248.36 & 0.87 & 7.73 & 19.9 & 0.61 \\
\hline 343.978 & Max WS & $25-\mathrm{yr}$ & 05Маy2014 1236 & 11.32 & 247.75 & 248.54 & 0.98 & 11.77 & 24.36 & 0.79 \\
\hline 343.978 & Max WS & $50-y r$ & 05Мay2014 1236 & 12.7 & 247.75 & 248.57 & 1.04 & 12.59 & 25.16 & 0.82 \\
\hline 343.978 & Max WS & $100-y r$ & 05Маy2014 1230 & 17.74 & 247.75 & 248.69 & 1.18 & 15.71 & 27.88 & 0.94 \\
\hline 343.978 & Max WS & $500-y r$ & 05Маy2014 1224 & 27.18 & 247.75 & 248.88 & 1.36 & 21.56 & 32.46 & 1.13 \\
\hline 318.111 & Max WS & $2-y r$ & 05Маy2014 1318 & 1.41 & 247.65 & 247.91 & 0.78 & 1.81 & 10.95 & 0.26 \\
\hline 318.111 & Max WS & $5-\mathrm{yr}$ & 05May2014 1318 & -0.02 & 247.65 & 247.92 & -0.01 & 2 & 11.25 & 0.27 \\
\hline 318.111 & Max WS & $10-y r$ & 05Мау2014 1248 & 6.65 & 247.65 & 248.24 & 1.02 & 6.54 & 17.96 & 0.59 \\
\hline 318.111 & Max WS & $25-y r$ & 05Маy2014 1236 & 11.27 & 247.65 & 248.42 & 1.12 & 10.19 & 22.13 & 0.77 \\
\hline 318.111 & Max WS & $50-\mathrm{yr}$ & 05May2014 1236 & 12.68 & 247.65 & 248.45 & 1.18 & 10.91 & 22.89 & 0.8 \\
\hline 318.111 & Max WS & $100-\mathrm{yr}$ & 05May2014 1230 & 17.7 & 247.65 & 248.57 & 1.33 & 13.71 & 25.42 & 0.92 \\
\hline 318.111 & Max WS & $500-y r$ & 05May2014 1224 & 27.06 & 247.65 & 248.75 & 1.53 & 18.85 & 29.63 & 1.1 \\
\hline 284.899 & Max WS & $2-\mathrm{yr}$ & 05Маy2014 1318 & 1.41 & 247.49 & 247.77 & 0.64 & 2.2 & 12.12 & 0.28 \\
\hline 284.899 & Max WS & $5-y r$ & 05May2014 1318 & 1.46 & 247.49 & 247.76 & 0.68 & 2.13 & 11.99 & 0.27 \\
\hline 284.899 & Max WS & $10-\mathrm{yr}$ & 05Мау2014 1242 & 6.61 & 247.49 & 248.1 & 0.9 & 7.35 & 19.76 & 0.61 \\
\hline 284.899 & Max WS & $25-y r$ & 05May2014 1236 & 11.21 & 247.49 & 248.29 & 0.96 & 11.63 & 24.35 & 0.8 \\
\hline 284.899 & Max WS & $50-\mathrm{yr}$ & 05Мay2014 1236 & 12.65 & 247.49 & 248.32 & 1.02 & 12.46 & 25.09 & 0.83 \\
\hline 284.899 & Max WS & $100-\mathrm{yr}$ & 05May2014 1230 & 17.65 & 247.49 & 248.45 & 1.13 & 15.69 & 27.74 & 0.96 \\
\hline 284.899 & Max WS & $500-y r$ & 05Мay2014 1224 & 26.92 & 247.49 & 248.64 & 1.28 & 21.61 & 32.23 & 1.15 \\
\hline 244.681 & Max WS & $2-y r$ & 05Мay2014 1324 & 1.41 & 247.05 & 247.32 & 1.03 & 1.37 & 8.83 & 0.27 \\
\hline 244.681 & Max WS & $5-y r$ & 05Мay2014 1318 & -0.09 & 247.05 & 247.31 & -0.07 & 1.33 & 8.76 & 0.26 \\
\hline 244.681 & Max WS & $10-y r$ & 05Мay2014 1248 & 6.63 & 247.05 & 247.68 & 1.18 & 5.6 & 14.8 & 0.63 \\
\hline 244.681 & Max WS & $25-\mathrm{yr}$ & 05May2014 1236 & 11.05 & 247.05 & 247.84 & 1.34 & 8.22 & 18.02 & 0.79 \\
\hline 244.681 & Max WS & $50-\mathrm{yr}$ & 05Маy2014 1236 & 12.55 & 247.05 & 247.88 & 1.39 & 9.06 & 18.91 & 0.83 \\
\hline
\end{tabular}




\begin{tabular}{|c|c|c|c|c|c|c|c|c|c|c|}
\hline $\begin{array}{l}\text { River } \\
\text { Sta }\end{array}$ & Profile & Plan & Time at Max & $\begin{array}{c}Q \\
\text { Total } \\
\left(\mathbf{m}^{3} / \mathbf{s}\right)\end{array}$ & $\begin{array}{c}\text { Min } \\
\text { Ch El } \\
(\mathbf{m}) \\
\end{array}$ & $\begin{array}{l}\text { W.S. } \\
\text { Elev } \\
(\mathbf{m})\end{array}$ & $\begin{array}{c}\text { Vel } \\
\text { Chnl } \\
(\mathbf{m} / \mathbf{s})\end{array}$ & $\begin{array}{l}\text { Flow } \\
\text { Area } \\
\left(\mathbf{m}^{2}\right) \\
\end{array}$ & $\begin{array}{c}\text { Top } \\
\text { Width } \\
\text { (m) } \\
\end{array}$ & $\begin{array}{c}\text { Max Chl } \\
\text { Dpth } \\
(\mathbf{m})\end{array}$ \\
\hline 244.681 & Max WS & $100-\mathrm{yr}$ & 05Маy2014 1230 & 17.48 & 247.05 & 248.03 & 1.44 & 12.12 & 22.15 & 0.98 \\
\hline 244.681 & Max WS & $500-\mathrm{yr}$ & 05Мау2014 1224 & 26.55 & 247.05 & 248.19 & 1.66 & 16.02 & 25.97 & 1.14 \\
\hline 214.499 & Max WS & $2-y r$ & 05Мау2014 1324 & 1.41 & 246.61 & 247.2 & 0.23 & 6.09 & 16.73 & 0.59 \\
\hline 214.499 & Max WS & $5-\mathrm{yr}$ & 05Мау2014 1318 & 1.44 & 246.61 & 247.18 & 0.25 & 5.74 & 16.26 & 0.57 \\
\hline 214.499 & Max WS & $10-\mathrm{yr}$ & 05Мау2014 1248 & 6.59 & 246.61 & 247.61 & 0.45 & 14.56 & 25.55 & 1 \\
\hline 214.499 & Max WS & $25-y r$ & 05Мay2014 1236 & 10.94 & 246.61 & 247.76 & 0.59 & 18.91 & 29.07 & 1.15 \\
\hline 214.499 & Max WS & $50-\mathrm{yr}$ & 05Мау2014 1236 & 12.46 & 246.61 & 247.82 & 0.63 & 20.46 & 30.16 & 1.21 \\
\hline 214.499 & Max WS & $100-\mathrm{yr}$ & 05Мау2014 1230 & 17.36 & 246.61 & 247.98 & 0.72 & 25.62 & 33.76 & 1.37 \\
\hline 214.499 & Max WS & $500-\mathrm{yr}$ & 05Маy2014 1224 & 26.32 & 246.61 & 248.15 & 0.9 & 31.61 & 37.8 & 1.54 \\
\hline 214.498 & Max WS & $2-y r$ & 05Маy2014 1324 & 1.4 & 246.61 & 246.84 & 1.01 & 1.38 & 9.53 & 0.23 \\
\hline 214.498 & Max WS & $5-y r$ & 05May2014 1318 & 1.41 & 246.61 & 246.84 & 1.08 & 1.31 & 9.38 & 0.23 \\
\hline 214.498 & Max WS & $10-\mathrm{yr}$ & 05Мау2014 1248 & 6.53 & 246.61 & 247.12 & 1.38 & 4.74 & 14.89 & 0.51 \\
\hline 214.498 & Max WS & $25-\mathrm{yr}$ & 05Мay2014 1236 & 10.72 & 246.61 & 247.24 & 1.6 & 6.72 & 17.55 & 0.63 \\
\hline 214.498 & Max WS & $50-\mathrm{yr}$ & 05Мау2014 1236 & 12.27 & 246.61 & 247.29 & 1.63 & 7.54 & 18.53 & 0.68 \\
\hline 214.498 & Max WS & $100-\mathrm{yr}$ & 05Мау2014 1230 & 17.11 & 246.61 & 247.39 & 1.78 & 9.63 & 20.84 & 0.78 \\
\hline 214.498 & Max WS & $500-\mathrm{yr}$ & 05Мау2014 1224 & 25.84 & 246.61 & 247.53 & 2.04 & 12.65 & 23.79 & 0.92 \\
\hline 147.881 & Max WS & $2-y r$ & 05Мау2014 1324 & 1.4 & 245.82 & 246.04 & 1.2 & 1.16 & 8.26 & 0.22 \\
\hline 147.881 & Max WS & $5-\mathrm{yr}$ & 05Мay2014 1318 & 1.41 & 245.82 & 246.04 & 1.25 & 1.12 & 8.14 & 0.22 \\
\hline 147.881 & Max WS & $10-\mathrm{yr}$ & 05Мау2014 1248 & 6.48 & 245.82 & 246.35 & 1.34 & 4.83 & 14.77 & 0.53 \\
\hline 147.881 & Max WS & $25-\mathrm{yr}$ & 05Мау2014 1242 & 10.62 & 245.82 & 246.51 & 1.44 & 7.37 & 17.98 & 0.69 \\
\hline 147.881 & Max WS & $50-\mathrm{yr}$ & 05Маy2014 1236 & 12.1 & 245.82 & 246.56 & 1.44 & 8.38 & 19.07 & 0.74 \\
\hline 147.881 & Max WS & $100-\mathrm{yr}$ & 05Мау2014 1230 & 16.88 & 245.82 & 246.69 & 1.54 & 10.93 & 21.72 & 0.87 \\
\hline 147.881 & Max WS & $500-\mathrm{yr}$ & 05Маy2014 1230 & 25.57 & 245.82 & 246.91 & 1.58 & 16.15 & 26.25 & 1.09 \\
\hline 79.942 & Max WS & $2-y r$ & 05Мay2014 1330 & 1.4 & 245.12 & 245.49 & 0.66 & 2.12 & 8.94 & 0.37 \\
\hline 79.942 & Max WS & $5-y r$ & 05May2014 1324 & 0.02 & 245.12 & 245.5 & 0.01 & 2.24 & 9.1 & 0.38 \\
\hline 79.942 & Max WS & $10-y r$ & 05Мay2014 1254 & 6.34 & 245.12 & 245.89 & 0.95 & 6.69 & 14.01 & 0.77 \\
\hline 79.942 & Max WS & $25-y r$ & 05Мay2014 1242 & 10.59 & 245.12 & 246.09 & 1.08 & 9.83 & 16.7 & 0.97 \\
\hline 79.942 & Max WS & $50-\mathrm{yr}$ & 05May2014 1242 & 11.86 & 245.12 & 246.15 & 1.09 & 10.86 & 17.49 & 1.03 \\
\hline 79.942 & Max WS & $100-\mathrm{yr}$ & 05Мay2014 1236 & 16.48 & 245.12 & 246.32 & 1.18 & 13.97 & 19.92 & 1.2 \\
\hline 79.942 & Max WS & $500-\mathrm{yr}$ & 05Маy2014 1230 & 25.46 & 245.12 & 246.59 & 1.28 & 19.96 & 23.97 & 1.47 \\
\hline 53.415 & Max WS & $2-\mathrm{yr}$ & 05Маy2014 1330 & 1.4 & 244.76 & 245 & 1.69 & 0.82 & 5.41 & 0.24 \\
\hline 53.415 & Max WS & $5-y r$ & 05Мay2014 1324 & 0.08 & 244.76 & 245.01 & 0.1 & 0.87 & 5.5 & 0.25 \\
\hline 53.415 & Max WS & $10-\mathrm{yr}$ & 05Мay2014 1248 & 6.35 & 244.76 & 245.29 & 2.24 & 2.84 & 8.24 & 0.53 \\
\hline 53.415 & Max WS & $25-y r$ & 05Мay2014 1242 & 10.58 & 244.76 & 245.44 & 2.56 & 4.13 & 9.52 & 0.68 \\
\hline 53.415 & Max WS & $50-\mathrm{yr}$ & 05May2014 1242 & 11.86 & 244.76 & 245.48 & 2.61 & 4.54 & 9.88 & 0.72 \\
\hline
\end{tabular}




\begin{tabular}{|c|c|c|c|c|c|c|c|c|c|c|}
\hline $\begin{array}{c}\text { River } \\
\text { Sta }\end{array}$ & Profile & Plan & Time at Max & $\begin{array}{c}\mathbf{Q} \\
\text { Total } \\
\left(\mathbf{m}^{3} / \mathbf{s}\right) \\
\end{array}$ & $\begin{array}{c}\text { Min } \\
\text { Ch El } \\
(\mathbf{m})\end{array}$ & $\begin{array}{l}\text { W.S. } \\
\text { Elev } \\
(\mathbf{m})\end{array}$ & $\begin{array}{l}\text { Vel } \\
\text { Chnl } \\
(\mathbf{m} / \mathbf{s})\end{array}$ & $\begin{array}{l}\text { Flow } \\
\text { Area } \\
\left(\mathbf{m}^{2}\right) \\
\end{array}$ & $\begin{array}{c}\text { Top } \\
\text { Width } \\
(\mathbf{m})\end{array}$ & $\begin{array}{c}\text { Max Chl } \\
\text { Dpth } \\
\text { (m) }\end{array}$ \\
\hline 53.415 & Max WS & $100-\mathrm{yr}$ & 05Мay2014 1236 & 16.47 & 244.76 & 245.59 & 2.89 & 5.7 & 10.84 & 0.83 \\
\hline 53.415 & Max WS & $500-\mathrm{yr}$ & 05May2014 1230 & 25.43 & 244.76 & 245.77 & 3.27 & 7.77 & 12.36 & 1.01 \\
\hline 13.63 & Max WS & $2-\mathrm{yr}$ & 05Маy2014 1330 & 1.39 & 243.93 & 244.22 & 1.06 & 1.32 & 6.59 & 0.29 \\
\hline 13.63 & Max WS & $5-\mathrm{yr}$ & 05Мау2014 1324 & 0.02 & 243.93 & 244.5 & 0.01 & 3.57 & 9.17 & 0.57 \\
\hline 13.63 & Max WS & $10-y r$ & 05Мау2014 1254 & 6.34 & 243.93 & 244.53 & 1.65 & 3.85 & 9.42 & 0.6 \\
\hline 13.63 & Max WS & $25-\mathrm{yr}$ & 05Мay2014 1242 & 10.56 & 243.93 & 244.7 & 1.9 & 5.55 & 10.86 & 0.77 \\
\hline 13.63 & Max WS & $50-\mathrm{yr}$ & 05May2014 1242 & 11.86 & 243.93 & 244.74 & 1.98 & 6 & 11.2 & 0.81 \\
\hline 13.63 & Max WS & $100-\mathrm{yr}$ & 05May2014 1236 & 16.47 & 243.93 & 244.88 & 2.16 & 7.63 & 12.38 & 0.95 \\
\hline 13.63 & Max WS & $500-\mathrm{yr}$ & 05Маy2014 1230 & 25.39 & 243.93 & 245.09 & 2.42 & 10.48 & 14.33 & 1.16 \\
\hline
\end{tabular}

Table 26: Unsteady GLD (During mining) cross-sectional properties

\begin{tabular}{|c|c|c|c|c|c|c|c|c|c|c|}
\hline $\begin{array}{l}\text { River } \\
\text { Sta }\end{array}$ & Profile & Plan & Time at Max & $\begin{array}{c}\mathbf{Q} \\
\text { Total } \\
\left(\mathbf{m}^{3} / \mathbf{s}\right)\end{array}$ & $\begin{array}{l}\text { Min } \\
\text { Ch El } \\
(\mathbf{m})\end{array}$ & $\begin{array}{l}\text { W.S. } \\
\text { Elev } \\
(\mathbf{m})\end{array}$ & $\begin{array}{l}\text { Vel } \\
\text { Chnl } \\
(\mathbf{m} / \mathbf{s})\end{array}$ & $\begin{array}{l}\text { Flow } \\
\text { Area } \\
\left(\mathbf{m}^{2}\right)\end{array}$ & $\begin{array}{c}\text { Top } \\
\text { Width } \\
\text { (m) }\end{array}$ & $\begin{array}{c}\text { Max Chl } \\
\text { Dpth } \\
\text { (m) }\end{array}$ \\
\hline 2097.011 & Max WS & $2-\mathrm{yr}$ & 05Мау2014 1206 & 23.93 & 264.87 & 266.89 & 1.17 & 20.47 & 16.58 & 2.02 \\
\hline 2097.011 & Max WS & $5-\mathrm{yr}$ & 05May2014 1206 & 35.52 & 264.87 & 267.3 & 1.25 & 30.32 & 31.64 & 2.43 \\
\hline 2097.011 & Max WS & $10-\mathrm{yr}$ & 05Мay2014 1206 & 46.44 & 264.87 & 267.63 & 1.26 & 42.9 & 44.21 & 2.76 \\
\hline 2097.011 & Max WS & $25-\mathrm{yr}$ & 05Мay2014 1206 & 58.13 & 264.87 & 267.94 & 1.23 & 57.93 & 50.78 & 3.07 \\
\hline 2097.011 & Max WS & $50-\mathrm{yr}$ & 05Мау2014 1206 & 64 & 264.87 & 268.08 & 1.23 & 64.9 & 53.82 & 3.21 \\
\hline 2097.011 & Max WS & $100-\mathrm{yr}$ & 05May2014 1206 & 73.86 & 264.87 & 268.33 & 1.19 & 79.53 & 58.85 & 3.46 \\
\hline 2097.011 & Max WS & $500-\mathrm{yr}$ & 05Мay2014 1206 & 95.71 & 264.87 & 268.88 & 1.1 & 114.5 & 69.87 & 4.01 \\
\hline 2052.742 & Max WS & $2-\mathrm{yr}$ & 05Мау2014 1206 & 23.35 & 264.51 & 265.54 & 3.7 & 6.31 & 9.74 & 1.03 \\
\hline 2052.742 & Max WS & $5-\mathrm{yr}$ & 05May2014 1206 & 34.45 & 264.51 & 265.69 & 4.4 & 7.83 & 10.5 & 1.18 \\
\hline 2052.742 & Max WS & $10-\mathrm{yr}$ & 05Мау2014 1206 & 44.94 & 264.51 & 265.8 & 4.95 & 9.08 & 11.09 & 1.29 \\
\hline 2052.742 & Max WS & $25-\mathrm{yr}$ & 05Мау2014 1206 & 56.15 & 264.51 & 265.9 & 5.48 & 10.24 & 11.64 & 1.39 \\
\hline 2052.742 & Max WS & $50-y r$ & 05Мау2014 1206 & 61.8 & 264.51 & 265.95 & 5.74 & 10.77 & 11.88 & 1.44 \\
\hline 2052.742 & Max WS & $100-\mathrm{yr}$ & 05May2014 1206 & 71.31 & 264.51 & 266.01 & 6.22 & 11.46 & 12.19 & 1.5 \\
\hline 2052.742 & Max WS & $500-\mathrm{yr}$ & 05Мау2014 1206 & 91.99 & 264.51 & 266.11 & 7.19 & 12.8 & 12.77 & 1.6 \\
\hline 2009.086 & Max WS & $2-y r$ & 05Мау2014 1206 & 22.99 & 263.84 & 264.93 & 1.9 & 12.11 & 17 & 1.09 \\
\hline 2009.086 & Max WS & $5-\mathrm{yr}$ & 05May2014 1206 & 34.07 & 263.84 & 265.14 & 2.15 & 15.89 & 18.9 & 1.3 \\
\hline 2009.086 & Max WS & $10-y r$ & 05Маy2014 1206 & 44.46 & 263.84 & 265.31 & 2.35 & 19.12 & 20.36 & 1.47 \\
\hline 2009.086 & Max WS & $25-\mathrm{yr}$ & 05May2014 1206 & 55.65 & 263.84 & 265.43 & 2.6 & 21.68 & 21.44 & 1.59 \\
\hline 2009.086 & Max WS & $50-\mathrm{yr}$ & 05Маy2014 1206 & 61.28 & 263.84 & 265.52 & 2.64 & 23.67 & 22.25 & 1.68 \\
\hline 2009.086 & Max WS & $100-\mathrm{yr}$ & 05Мay2014 1206 & 70.67 & 263.84 & 265.65 & 2.73 & 26.61 & 23.46 & 1.81 \\
\hline 2009.086 & Max WS & $500-\mathrm{yr}$ & 05May2014 1206 & 91.25 & 263.84 & 265.82 & 3.08 & 30.91 & 25.21 & 1.98 \\
\hline
\end{tabular}




\begin{tabular}{|c|c|c|c|c|c|c|c|c|c|c|}
\hline $\begin{array}{c}\text { River } \\
\text { Sta }\end{array}$ & Profile & Plan & Time at Max & $\begin{array}{c}\mathbf{Q} \\
\text { Total } \\
\left(\mathbf{m}^{3} / \mathbf{s}\right)\end{array}$ & $\begin{array}{c}\text { Min } \\
\text { Ch El } \\
(\mathbf{m})\end{array}$ & $\begin{array}{l}\text { W.S. } \\
\text { Elev } \\
(m)\end{array}$ & $\begin{array}{l}\text { Vel } \\
\text { Chnl } \\
(\mathbf{m} / \mathbf{s})\end{array}$ & $\begin{array}{l}\text { Flow } \\
\text { Area } \\
\left(\mathbf{m}^{2}\right)\end{array}$ & $\begin{array}{c}\text { Top } \\
\text { Width } \\
\text { (m) }\end{array}$ & $\begin{array}{c}\text { Max Chl } \\
\text { Dpth } \\
\text { (m) }\end{array}$ \\
\hline 1964.49 & Max WS & $2-y r$ & 05Мау2014 1206 & 22.54 & 263.35 & 264.19 & 2.37 & 9.49 & 18.23 & 0.84 \\
\hline 1964.49 & Max WS & $5-\mathrm{yr}$ & 05May2014 1206 & 33.57 & 263.35 & 264.35 & 2.66 & 12.61 & 20.81 & 1 \\
\hline 1964.49 & Max WS & $10-y r$ & 05Мау2014 1206 & 43.78 & 263.35 & 264.46 & 2.91 & 15.06 & 22.67 & 1.11 \\
\hline 1964.49 & Max WS & $25-\mathrm{yr}$ & 05May2014 1206 & 54.97 & 263.35 & 264.57 & 3.12 & 17.63 & 24.47 & 1.22 \\
\hline 1964.49 & Max WS & $50-\mathrm{yr}$ & 05May2014 1206 & 60.58 & 263.35 & 264.61 & 3.26 & 18.58 & 25.06 & 1.26 \\
\hline 1964.49 & Max WS & $100-y r$ & 05May2014 1206 & 69.84 & 263.35 & 264.68 & 3.43 & 20.39 & 26.15 & 1.33 \\
\hline 1964.49 & Max WS & $500-\mathrm{yr}$ & 05Мау2014 1206 & 90.22 & 263.35 & 264.81 & 3.76 & 24.1 & 28.46 & 1.46 \\
\hline 1925.761 & Max WS & $2-\mathrm{yr}$ & 05May2014 1206 & 21.89 & 263.04 & 263.91 & 1.19 & 20.23 & 42.25 & 0.87 \\
\hline 1925.761 & Max WS & $5-y r$ & 05May2014 1206 & 32.82 & 263.04 & 264.1 & 1.3 & 28.85 & 50.82 & 1.06 \\
\hline 1925.761 & Max WS & $10-\mathrm{yr}$ & 05May2014 1206 & 42.64 & 263.04 & 264.24 & 1.39 & 36.69 & 62 & 1.2 \\
\hline 1925.761 & Max WS & $25-y r$ & 05Мау2014 1206 & 53.7 & 263.04 & 264.38 & 1.44 & 46.82 & 77.25 & 1.34 \\
\hline 1925.761 & Max WS & $50-\mathrm{yr}$ & 05May2014 1206 & 58.92 & 263.04 & 264.42 & 1.49 & 50.04 & 80.3 & 1.38 \\
\hline 1925.761 & Max WS & $100-\mathrm{yr}$ & 05May2014 1206 & 68.15 & 263.04 & 264.51 & 1.53 & 57.35 & 86.38 & 1.47 \\
\hline 1925.761 & Max WS & $500-\mathrm{yr}$ & 05Мay2014 1206 & 88.05 & 263.04 & 264.72 & 1.53 & 76.26 & 97.6 & 1.68 \\
\hline 1874.546 & Max WS & $2-\mathrm{yr}$ & 05May2014 1206 & 20.13 & 262.4 & 263.46 & 1.33 & 15.3 & 26.3 & 1.06 \\
\hline 1874.546 & Max WS & $5-\mathrm{yr}$ & 05May2014 1206 & 30.65 & 262.4 & 263.61 & 1.62 & 19.48 & 30.48 & 1.21 \\
\hline 1874.546 & Max WS & $10-\mathrm{yr}$ & 05May2014 1206 & 39.55 & 262.4 & 263.71 & 1.83 & 22.81 & 34.04 & 1.31 \\
\hline 1874.546 & Max WS & $25-\mathrm{yr}$ & 05May2014 1206 & 49.95 & 262.4 & 263.81 & 2.04 & 26.31 & 38.18 & 1.41 \\
\hline 1874.546 & Max WS & $50-\mathrm{yr}$ & 05May2014 1206 & 54.12 & 262.4 & 263.85 & 2.11 & 27.93 & 40.06 & 1.45 \\
\hline 1874.546 & Max WS & $100-\mathrm{yr}$ & 05May2014 1206 & 63.11 & 262.4 & 263.95 & 2.21 & 31.86 & 46.11 & 1.55 \\
\hline 1874.546 & Max WS & $500-\mathrm{yr}$ & 05Мay2014 1206 & 81.91 & 262.4 & 264.07 & 2.49 & 37.73 & 50.01 & 1.67 \\
\hline 1828.159 & Max WS & $2-\mathrm{yr}$ & 05May2014 1212 & 19.49 & 262.13 & 262.97 & 1.77 & 11.03 & 24.77 & 0.84 \\
\hline 1828.159 & Max WS & $5-\mathrm{yr}$ & 05May2014 1212 & 29.03 & 262.13 & 263.13 & 1.94 & 15.23 & 28.77 & 1 \\
\hline 1828.159 & Max WS & $10-y r$ & 05Мay2014 1212 & 37.91 & 262.13 & 263.25 & 2.08 & 18.97 & 32.12 & 1.12 \\
\hline 1828.159 & Max WS & $25-y r$ & 05Мay2014 1212 & 47.54 & 262.13 & 263.38 & 2.17 & 23.22 & 35.81 & 1.25 \\
\hline 1828.159 & Max WS & $50-\mathrm{yr}$ & 05May2014 1212 & 52.17 & 262.13 & 263.43 & 2.21 & 25.24 & 37.34 & 1.3 \\
\hline 1828.159 & Max WS & $100-\mathrm{yr}$ & 05Мay2014 1212 & 60.42 & 262.13 & 263.54 & 2.24 & 29.41 & 40.36 & 1.41 \\
\hline 1828.159 & Max WS & $500-y r$ & 05May2014 1212 & 78.28 & 262.13 & 263.78 & 2.22 & 39.92 & 48.39 & 1.65 \\
\hline 1788.723 & Max WS & $2-\mathrm{yr}$ & 05May2014 1212 & 19.43 & 261.54 & 262.8 & 0.87 & 23.16 & 33.97 & 1.26 \\
\hline 1788.723 & Max WS & $5-\mathrm{yr}$ & 05Мay2014 1212 & 28.97 & 261.54 & 263 & 1.02 & 30.25 & 38.03 & 1.46 \\
\hline 1788.723 & Max WS & $10-y r$ & 05Мay2014 1212 & 37.84 & 261.54 & 263.15 & 1.13 & 36.08 & 40.74 & 1.61 \\
\hline 1788.723 & Max WS & $25-y r$ & 05Мау2014 1212 & 47.4 & 261.54 & 263.3 & 1.22 & 42.55 & 43.42 & 1.76 \\
\hline 1788.723 & Max WS & $50-\mathrm{yr}$ & 05May2014 1212 & 52 & 261.54 & 263.36 & 1.26 & 45.29 & 44.5 & 1.82 \\
\hline 1788.723 & Max WS & $100-\mathrm{yr}$ & 05Мау2014 1212 & 60.14 & 261.54 & 263.49 & 1.31 & 50.91 & 46.52 & 1.95 \\
\hline 1788.723 & Max WS & $500-\mathrm{yr}$ & 05May2014 1212 & 77.78 & 261.54 & 263.75 & 1.38 & 63.78 & 51 & 2.21 \\
\hline
\end{tabular}




\begin{tabular}{|c|c|c|c|c|c|c|c|c|c|c|}
\hline $\begin{array}{l}\text { River } \\
\text { Sta }\end{array}$ & Profile & Plan & Time at Max & $\begin{array}{c}\mathbf{Q} \\
\text { Total } \\
\left(\mathbf{m}^{3} / \mathbf{s}\right)\end{array}$ & $\begin{array}{c}\text { Min } \\
\text { Ch El } \\
(\mathbf{m}) \\
\end{array}$ & $\begin{array}{l}\text { W.S. } \\
\text { Elev } \\
(\mathbf{m})\end{array}$ & $\begin{array}{c}\text { Vel } \\
\text { Chnl } \\
(\mathbf{m} / \mathbf{s}) \\
\end{array}$ & $\begin{array}{l}\text { Flow } \\
\text { Area } \\
\left(\mathbf{m}^{2}\right) \\
\end{array}$ & $\begin{array}{c}\text { Top } \\
\text { Width } \\
(\mathbf{m})\end{array}$ & $\begin{array}{c}\text { Max Chl } \\
\text { Dpth } \\
\text { (m) }\end{array}$ \\
\hline 1742.556 & Max WS & $2-y r$ & 05Мay2014 1212 & 19.33 & 261.5 & 262.71 & 0.98 & 20 & 29.32 & 1.21 \\
\hline 1742.556 & Max WS & $5-\mathrm{yr}$ & 05May2014 1212 & 28.87 & 261.5 & 262.89 & 1.17 & 25.62 & 32.9 & 1.39 \\
\hline 1742.556 & Max WS & $10-\mathrm{yr}$ & 05Мay2014 1212 & 37.72 & 261.5 & 263.03 & 1.3 & 30.46 & 35.67 & 1.53 \\
\hline 1742.556 & Max WS & $25-\mathrm{yr}$ & 05Мay2014 1212 & 47.16 & 261.5 & 263.18 & 1.4 & 36.02 & 38.67 & 1.68 \\
\hline 1742.556 & Max WS & $50-y r$ & 05Мay2014 1212 & 51.71 & 261.5 & 263.24 & 1.45 & 38.49 & 39.95 & 1.74 \\
\hline 1742.556 & Max WS & $100-\mathrm{yr}$ & 05May2014 1212 & 59.69 & 261.5 & 263.37 & 1.48 & 43.89 & 42.76 & 1.87 \\
\hline 1742.556 & Max WS & $500-\mathrm{yr}$ & 05Мау2014 1212 & 77.01 & 261.5 & 263.65 & 1.52 & 56.84 & 49.5 & 2.15 \\
\hline 1695.655 & Max WS & $2-y r$ & 05Мау2014 1212 & 19.19 & 261.28 & 262.33 & 1.8 & 10.73 & 18.4 & 1.05 \\
\hline 1695.655 & Max WS & $5-\mathrm{yr}$ & 05May2014 1212 & 28.67 & 261.28 & 262.58 & 1.87 & 16.19 & 25.31 & 1.3 \\
\hline 1695.655 & Max WS & $10-\mathrm{yr}$ & 05May2014 1212 & 37.35 & 261.28 & 262.79 & 1.88 & 22.4 & 36.63 & 1.51 \\
\hline 1695.655 & Max WS & $25-y r$ & 05Мау2014 1212 & 46.58 & 261.28 & 263.01 & 1.74 & 33.49 & 54.39 & 1.73 \\
\hline 1695.655 & Max WS & $50-\mathrm{yr}$ & 05May2014 1212 & 51 & 261.28 & 263.11 & 1.67 & 38.79 & 56.69 & 1.83 \\
\hline 1695.655 & Max WS & $100-\mathrm{yr}$ & 05May2014 1212 & 58.84 & 261.28 & 263.28 & 1.56 & 48.6 & 60.72 & 2 \\
\hline 1695.655 & Max WS & $500-\mathrm{yr}$ & 05Мay2014 1212 & 75.86 & 261.28 & 263.61 & 1.4 & 70 & 68.04 & 2.33 \\
\hline 1651.05 & Max WS & $2-\mathrm{yr}$ & 05May2014 1212 & 18.93 & 260.78 & 262.2 & 0.91 & 20.75 & 22.08 & 1.42 \\
\hline 1651.05 & Max WS & $5-\mathrm{yr}$ & 05May2014 1212 & 28.34 & 260.78 & 262.51 & 1.01 & 28.07 & 24.88 & 1.73 \\
\hline 1651.05 & Max WS & $10-\mathrm{yr}$ & 05May2014 1212 & 36.83 & 260.78 & 262.74 & 1.09 & 33.94 & 26.95 & 1.96 \\
\hline 1651.05 & Max WS & $25-\mathrm{yr}$ & 05May2014 1212 & 45.91 & 260.78 & 262.96 & 1.15 & 40.13 & 29.06 & 2.18 \\
\hline 1651.05 & Max WS & $50-\mathrm{yr}$ & 05May2014 1212 & 50.23 & 260.78 & 263.05 & 1.18 & 42.82 & 30 & 2.27 \\
\hline 1651.05 & Max WS & $100-\mathrm{yr}$ & 05May2014 1212 & 57.99 & 260.78 & 263.21 & 1.23 & 47.83 & 31.58 & 2.43 \\
\hline 1651.05 & Max WS & $500-\mathrm{yr}$ & 05Мay2014 1212 & 74.84 & 260.78 & 263.53 & 1.31 & 58.52 & 34.99 & 2.75 \\
\hline 1617.21 & Max WS & $2-\mathrm{yr}$ & 05May2014 1212 & 18.67 & 260.56 & 262.14 & 1.02 & 18.39 & 19.16 & 1.58 \\
\hline 1617.21 & Max WS & $5-y r$ & 05May2014 1212 & 28.06 & 260.56 & 262.45 & 1.14 & 24.65 & 21.35 & 1.88 \\
\hline 1617.21 & Max WS & $10-\mathrm{yr}$ & 05May2014 1212 & 36.52 & 260.56 & 262.67 & 1.24 & 29.56 & 22.79 & 2.11 \\
\hline 1617.21 & Max WS & $25-\mathrm{yr}$ & 05Мay2014 1212 & 45.57 & 260.56 & 262.89 & 1.31 & 34.72 & 24.21 & 2.33 \\
\hline 1617.21 & Max WS & $50-y r$ & 05May2014 1212 & 49.84 & 260.56 & 262.98 & 1.35 & 36.93 & 24.78 & 2.42 \\
\hline 1617.21 & Max WS & $100-\mathrm{yr}$ & 05May2014 1212 & 57.59 & 260.56 & 263.14 & 1.4 & 41.01 & 25.67 & 2.58 \\
\hline 1617.21 & Max WS & $500-y r$ & 05May2014 1212 & 74.34 & 260.56 & 263.46 & 1.5 & 49.54 & 27.64 & 2.9 \\
\hline 1577.381 & Max WS & $2-\mathrm{yr}$ & 05May2014 1212 & 18.27 & 260.48 & 262.13 & 0.42 & 43.79 & 35.23 & 1.65 \\
\hline 1577.381 & Max WS & $5-\mathrm{yr}$ & 05May2014 1212 & 27.61 & 260.48 & 262.45 & 0.5 & 56.03 & 41.67 & 1.97 \\
\hline 1577.381 & Max WS & $10-\mathrm{yr}$ & 05May2014 1212 & 35.94 & 260.48 & 262.68 & 0.56 & 67.44 & 53.1 & 2.2 \\
\hline 1577.381 & Max WS & $25-y r$ & 05Мay2014 1212 & 44.94 & 260.48 & 262.91 & 0.6 & 80.12 & 59.04 & 2.43 \\
\hline 1577.381 & Max WS & $50-\mathrm{yr}$ & 05May2014 1212 & 49.14 & 260.48 & 263 & 0.62 & 85.68 & 60.55 & 2.52 \\
\hline 1577.381 & Max WS & $100-\mathrm{yr}$ & 05Мay2014 1212 & 56.85 & 260.48 & 263.17 & 0.65 & 96.33 & 64.97 & 2.69 \\
\hline 1577.381 & Max WS & $500-\mathrm{yr}$ & 05May2014 1212 & 73.43 & 260.48 & 263.5 & 0.7 & 118.96 & 73.34 & 3.02 \\
\hline
\end{tabular}




\begin{tabular}{|c|c|c|c|c|c|c|c|c|c|c|}
\hline $\begin{array}{l}\text { River } \\
\text { Sta }\end{array}$ & Profile & Plan & Time at Max & $\begin{array}{c}\mathbf{Q} \\
\text { Total } \\
\left(\mathbf{m}^{3} / \mathbf{s}\right)\end{array}$ & $\begin{array}{c}\text { Min } \\
\text { Ch El } \\
(\mathbf{m}) \\
\end{array}$ & $\begin{array}{l}\text { W.S. } \\
\text { Elev } \\
(\mathbf{m})\end{array}$ & $\begin{array}{c}\text { Vel } \\
\text { Chnl } \\
(\mathbf{m} / \mathbf{s}) \\
\end{array}$ & $\begin{array}{l}\text { Flow } \\
\text { Area } \\
\left(\mathbf{m}^{2}\right) \\
\end{array}$ & $\begin{array}{c}\text { Top } \\
\text { Width } \\
(\mathbf{m})\end{array}$ & $\begin{array}{c}\text { Max Chl } \\
\text { Dpth } \\
\text { (m) }\end{array}$ \\
\hline 1542.946 & Max WS & $2-y r$ & 05Мay2014 1212 & 17.99 & 260.49 & 261.86 & 2.1 & 8.56 & 9.57 & 1.37 \\
\hline 1542.946 & Max WS & $5-\mathrm{yr}$ & 05May2014 1212 & 27.3 & 260.49 & 262.13 & 2.42 & 11.28 & 10.61 & 1.64 \\
\hline 1542.946 & Max WS & $10-\mathrm{yr}$ & 05Мay2014 1212 & 35.52 & 260.49 & 262.33 & 2.64 & 13.45 & 11.23 & 1.84 \\
\hline 1542.946 & Max WS & $25-\mathrm{yr}$ & 05Мay2014 1212 & 44.47 & 260.49 & 262.53 & 2.82 & 15.79 & 11.85 & 2.04 \\
\hline 1542.946 & Max WS & $50-y r$ & 05Мay2014 1212 & 48.62 & 260.49 & 262.61 & 2.9 & 16.75 & 12.1 & 2.12 \\
\hline 1542.946 & Max WS & $100-\mathrm{yr}$ & 05May2014 1212 & 56.29 & 260.49 & 262.76 & 3.03 & 18.56 & 12.55 & 2.27 \\
\hline 1542.946 & Max WS & $500-\mathrm{yr}$ & 05Мау2014 1212 & 72.75 & 260.49 & 263.06 & 3.22 & 22.58 & 13.54 & 2.57 \\
\hline 1504.079 & Max WS & $2-y r$ & 05Мау2014 1212 & 17.87 & 260.31 & 261.54 & 2.01 & 8.89 & 10.81 & 1.23 \\
\hline 1504.079 & Max WS & $5-\mathrm{yr}$ & 05Мay2014 1212 & 27.18 & 260.31 & 261.76 & 2.4 & 11.32 & 11.78 & 1.45 \\
\hline 1504.079 & Max WS & $10-y r$ & 05Мау2014 1212 & 35.38 & 260.31 & 261.9 & 2.71 & 13.04 & 12.43 & 1.59 \\
\hline 1504.079 & Max WS & $25-y r$ & 05Мау2014 1212 & 44.33 & 260.31 & 262.02 & 3.04 & 14.59 & 12.98 & 1.71 \\
\hline 1504.079 & Max WS & $50-\mathrm{yr}$ & 05May2014 1212 & 48.46 & 260.31 & 262.07 & 3.17 & 15.27 & 13.2 & 1.76 \\
\hline 1504.079 & Max WS & $100-\mathrm{yr}$ & 05May2014 1212 & 56.12 & 260.31 & 262.17 & 3.39 & 16.56 & 13.61 & 1.86 \\
\hline 1504.079 & Max WS & $500-\mathrm{yr}$ & 05Мay2014 1212 & 72.55 & 260.31 & 262.35 & 3.83 & 19.03 & 14.34 & 2.04 \\
\hline 1467.659 & Max WS & $2-\mathrm{yr}$ & 05May2014 1212 & 17.7 & 260.12 & 261.38 & 1.52 & 11.67 & 14.6 & 1.26 \\
\hline 1467.659 & Max WS & $5-\mathrm{yr}$ & 05May2014 1212 & 27.04 & 260.12 & 261.58 & 1.83 & 14.82 & 16.45 & 1.46 \\
\hline 1467.659 & Max WS & $10-\mathrm{yr}$ & 05May2014 1212 & 35.24 & 260.12 & 261.72 & 2.06 & 17.12 & 17.93 & 1.6 \\
\hline 1467.659 & Max WS & $25-y r$ & 05Мay2014 1212 & 44.15 & 260.12 & 261.85 & 2.27 & 19.63 & 19.94 & 1.73 \\
\hline 1467.659 & Max WS & $50-\mathrm{yr}$ & 05May2014 1212 & 48.18 & 260.12 & 261.95 & 2.26 & 21.8 & 24.19 & 1.83 \\
\hline 1467.659 & Max WS & $100-\mathrm{yr}$ & 05May2014 1212 & 55.86 & 260.12 & 262.1 & 2.3 & 26.1 & 33.29 & 1.98 \\
\hline 1467.659 & Max WS & $500-\mathrm{yr}$ & 05Мay2014 1212 & 72.1 & 260.12 & 262.44 & 2.17 & 38.5 & 37.48 & 2.32 \\
\hline 1425.307 & Max WS & $2-\mathrm{yr}$ & 05May2014 1212 & 17.49 & 259.66 & 260.73 & 2.39 & 7.31 & 12.01 & 1.07 \\
\hline 1425.307 & Max WS & $5-y r$ & 05May2014 1212 & 26.84 & 259.66 & 260.95 & 2.62 & 10.24 & 14.61 & 1.29 \\
\hline 1425.307 & Max WS & $10-\mathrm{yr}$ & 05May2014 1212 & 35.01 & 259.66 & 261.1 & 2.81 & 12.77 & 19.11 & 1.44 \\
\hline 1425.307 & Max WS & $25-\mathrm{yr}$ & 05Мay2014 1212 & 43.89 & 259.66 & 261.22 & 3.05 & 15.3 & 23.42 & 1.56 \\
\hline 1425.307 & Max WS & $50-\mathrm{yr}$ & 05May2014 1212 & 47.87 & 259.66 & 261.23 & 3.29 & 15.5 & 23.7 & 1.57 \\
\hline 1425.307 & Max WS & $100-\mathrm{yr}$ & 05May2014 1212 & 55.55 & 259.66 & 261.29 & 3.55 & 17.04 & 26.34 & 1.63 \\
\hline 1425.307 & Max WS & $500-y r$ & 05May2014 1212 & 71.56 & 259.66 & 261.36 & 4.21 & 19.06 & 29.5 & 1.7 \\
\hline 1392.843 & Max WS & $2-\mathrm{yr}$ & 05May2014 1212 & 17.35 & 259.14 & 260.26 & 2.22 & 7.8 & 11.12 & 1.12 \\
\hline 1392.843 & Max WS & $5-y r$ & 05May2014 1212 & 26.7 & 259.14 & 260.5 & 2.5 & 10.69 & 12.87 & 1.36 \\
\hline 1392.843 & Max WS & $10-\mathrm{yr}$ & 05May2014 1212 & 34.81 & 259.14 & 260.69 & 2.61 & 13.31 & 14.94 & 1.55 \\
\hline 1392.843 & Max WS & $25-y r$ & 05Мay2014 1212 & 43.63 & 259.14 & 260.86 & 2.73 & 16.31 & 23.6 & 1.72 \\
\hline 1392.843 & Max WS & $50-\mathrm{yr}$ & 05May2014 1212 & 47.63 & 259.14 & 260.94 & 2.73 & 18.4 & 30.12 & 1.8 \\
\hline 1392.843 & Max WS & $100-\mathrm{yr}$ & 05Мay2014 1212 & 55.28 & 259.14 & 261.06 & 2.74 & 22.49 & 35.06 & 1.92 \\
\hline 1392.843 & Max WS & $500-\mathrm{yr}$ & 05May2014 1212 & 71.18 & 259.14 & 261.33 & 2.58 & 32.58 & 38.25 & 2.19 \\
\hline
\end{tabular}




\begin{tabular}{|c|c|c|c|c|c|c|c|c|c|c|}
\hline $\begin{array}{l}\text { River } \\
\text { Sta }\end{array}$ & Profile & Plan & Time at Max & $\begin{array}{c}\mathbf{Q} \\
\text { Total } \\
\left(\mathbf{m}^{3} / \mathbf{s}\right)\end{array}$ & $\begin{array}{c}\text { Min } \\
\text { Ch El } \\
(\mathbf{m}) \\
\end{array}$ & $\begin{array}{l}\text { W.S. } \\
\text { Elev } \\
(\mathbf{m})\end{array}$ & $\begin{array}{l}\text { Vel } \\
\text { Chnl } \\
(\mathbf{m} / \mathbf{s}) \\
\end{array}$ & $\begin{array}{l}\text { Flow } \\
\text { Area } \\
\left(\mathbf{m}^{2}\right) \\
\end{array}$ & $\begin{array}{c}\text { Top } \\
\text { Width } \\
(\mathbf{m})\end{array}$ & $\begin{array}{c}\text { Max Chl } \\
\text { Dpth } \\
(\mathbf{m})\end{array}$ \\
\hline 1358.799 & Max WS & $2-y r$ & 05Мay2014 1212 & 17.23 & 258.63 & 259.65 & 2.54 & 6.79 & 10.53 & 1.02 \\
\hline 1358.799 & Max WS & $5-\mathrm{yr}$ & 05May2014 1212 & 26.56 & 258.63 & 259.87 & 2.86 & 9.28 & 11.89 & 1.24 \\
\hline 1358.799 & Max WS & $10-\mathrm{yr}$ & 05Мay2014 1212 & 34.61 & 258.63 & 260.04 & 3.04 & 11.37 & 12.94 & 1.41 \\
\hline 1358.799 & Max WS & $25-\mathrm{yr}$ & 05Мay2014 1212 & 43.36 & 258.63 & 260.2 & 3.2 & 13.54 & 14.29 & 1.57 \\
\hline 1358.799 & Max WS & $50-y r$ & 05Мay2014 1212 & 47.32 & 258.63 & 260.27 & 3.25 & 14.57 & 14.87 & 1.64 \\
\hline 1358.799 & Max WS & $100-\mathrm{yr}$ & 05May2014 1212 & 54.95 & 258.63 & 260.38 & 3.4 & 16.18 & 15.84 & 1.74 \\
\hline 1358.799 & Max WS & $500-\mathrm{yr}$ & 05Мау2014 1212 & 70.74 & 258.63 & 260.56 & 3.73 & 19.23 & 17.89 & 1.93 \\
\hline 1329.439 & Max WS & $2-y r$ & 05Мау2014 1212 & 17.11 & 258.21 & 259.36 & 2 & 8.56 & 11.66 & 1.15 \\
\hline 1329.439 & Max WS & $5-\mathrm{yr}$ & 05May2014 1212 & 26.39 & 258.21 & 259.65 & 2.15 & 12.28 & 13.45 & 1.44 \\
\hline 1329.439 & Max WS & $10-\mathrm{yr}$ & 05May2014 1212 & 34.43 & 258.21 & 259.86 & 2.27 & 15.21 & 14.61 & 1.65 \\
\hline 1329.439 & Max WS & $25-y r$ & 05Мау2014 1212 & 43.16 & 258.21 & 260.07 & 2.38 & 18.42 & 16.61 & 1.86 \\
\hline 1329.439 & Max WS & $50-\mathrm{yr}$ & 05May2014 1212 & 47.1 & 258.21 & 260.15 & 2.43 & 19.75 & 17.31 & 1.94 \\
\hline 1329.439 & Max WS & $100-\mathrm{yr}$ & 05May2014 1212 & 54.69 & 258.21 & 260.29 & 2.54 & 22.28 & 18.54 & 2.08 \\
\hline 1329.439 & Max WS & $500-\mathrm{yr}$ & 05Мay2014 1212 & 70.27 & 258.21 & 260.56 & 2.7 & 28.3 & 31.02 & 2.35 \\
\hline 1302.462 & Max WS & $2-\mathrm{yr}$ & 05May2014 1212 & 16.94 & 257.76 & 259.35 & 0.92 & 18.42 & 17.36 & 1.59 \\
\hline 1302.462 & Max WS & $5-\mathrm{yr}$ & 05May2014 1212 & 26.14 & 257.76 & 259.68 & 1.06 & 24.57 & 19.64 & 1.92 \\
\hline 1302.462 & Max WS & $10-\mathrm{yr}$ & 05May2014 1212 & 34.19 & 257.76 & 259.91 & 1.17 & 29.33 & 21.48 & 2.15 \\
\hline 1302.462 & Max WS & $25-y r$ & 05Мay2014 1212 & 42.81 & 257.76 & 260.14 & 1.25 & 34.55 & 23.68 & 2.38 \\
\hline 1302.462 & Max WS & $50-\mathrm{yr}$ & 05May2014 1212 & 46.73 & 257.76 & 260.23 & 1.29 & 36.81 & 32.41 & 2.47 \\
\hline 1302.462 & Max WS & $100-\mathrm{yr}$ & 05May2014 1212 & 54.11 & 257.76 & 260.39 & 1.34 & 43.52 & 51.12 & 2.63 \\
\hline 1302.462 & Max WS & $500-\mathrm{yr}$ & 05Мay2014 1212 & 69.41 & 257.76 & 260.68 & 1.38 & 59.28 & 56.54 & 2.92 \\
\hline 1264.23 & Max WS & $2-\mathrm{yr}$ & 05May2014 1218 & 16.22 & 257.59 & 258.72 & 2.12 & 7.67 & 10.53 & 1.13 \\
\hline 1264.23 & Max WS & $5-y r$ & 05May2014 1212 & 25.58 & 257.59 & 258.94 & 2.53 & 10.11 & 11.62 & 1.35 \\
\hline 1264.23 & Max WS & $10-\mathrm{yr}$ & 05May2014 1212 & 33.58 & 257.59 & 259.09 & 2.81 & 11.94 & 12.37 & 1.5 \\
\hline 1264.23 & Max WS & $25-\mathrm{yr}$ & 05Мay2014 1212 & 42.01 & 257.59 & 259.22 & 3.09 & 13.6 & 13 & 1.63 \\
\hline 1264.23 & Max WS & $50-\mathrm{yr}$ & 05May2014 1212 & 45.86 & 257.59 & 259.29 & 3.18 & 14.44 & 13.31 & 1.7 \\
\hline 1264.23 & Max WS & $100-\mathrm{yr}$ & 05May2014 1218 & 49.04 & 257.59 & 259.37 & 3.15 & 15.57 & 13.76 & 1.78 \\
\hline 1264.23 & Max WS & $500-y r$ & 05May2014 1218 & 64 & 257.59 & 259.64 & 3.3 & 19.4 & 15.19 & 2.05 \\
\hline 1230.005 & Max WS & $2-\mathrm{yr}$ & 05May2014 1218 & 16.2 & 257.24 & 258.59 & 1.37 & 11.8 & 13.42 & 1.35 \\
\hline 1230.005 & Max WS & $5-y r$ & 05May2014 1212 & 25.4 & 257.24 & 258.81 & 1.71 & 14.86 & 14.59 & 1.57 \\
\hline 1230.005 & Max WS & $10-\mathrm{yr}$ & 05May2014 1212 & 33.37 & 257.24 & 258.97 & 1.93 & 17.25 & 15.44 & 1.73 \\
\hline 1230.005 & Max WS & $25-y r$ & 05Мау2014 1218 & 38.79 & 257.24 & 259.11 & 1.99 & 19.49 & 16.34 & 1.87 \\
\hline 1230.005 & Max WS & $50-\mathrm{yr}$ & 05May2014 1218 & 42.54 & 257.24 & 259.2 & 2.04 & 20.97 & 17.31 & 1.96 \\
\hline 1230.005 & Max WS & $100-\mathrm{yr}$ & 05Мау2014 1218 & 48.99 & 257.24 & 259.32 & 2.13 & 23.87 & 28.67 & 2.08 \\
\hline 1230.005 & Max WS & $500-\mathrm{yr}$ & 05May2014 1218 & 63.65 & 257.24 & 259.69 & 1.97 & 40.04 & 53.14 & 2.45 \\
\hline
\end{tabular}




\begin{tabular}{|c|c|c|c|c|c|c|c|c|c|c|}
\hline $\begin{array}{l}\text { River } \\
\text { Sta }\end{array}$ & Profile & Plan & Time at Max & $\begin{array}{c}\mathbf{Q} \\
\text { Total } \\
\left(\mathbf{m}^{3} / \mathbf{s}\right)\end{array}$ & $\begin{array}{c}\text { Min } \\
\text { Ch El } \\
(\mathbf{m}) \\
\end{array}$ & $\begin{array}{l}\text { W.S. } \\
\text { Elev } \\
(\mathrm{m})\end{array}$ & $\begin{array}{c}\text { Vel } \\
\text { Chnl } \\
(\mathbf{m} / \mathbf{s}) \\
\end{array}$ & $\begin{array}{l}\text { Flow } \\
\text { Area } \\
\left(\mathbf{m}^{2}\right) \\
\end{array}$ & $\begin{array}{c}\text { Top } \\
\text { Width } \\
(\mathbf{m})\end{array}$ & $\begin{array}{c}\text { Max Chl } \\
\text { Dpth } \\
(\mathbf{m})\end{array}$ \\
\hline 1191.977 & Max WS & $2-y r$ & 05Мay2014 1218 & 16.14 & 256.91 & 258.44 & 1 & 16.2 & 18.14 & 1.53 \\
\hline 1191.977 & Max WS & $5-\mathrm{yr}$ & 05May2014 1218 & 23.95 & 256.91 & 258.63 & 1.2 & 21.37 & 33.48 & 1.72 \\
\hline 1191.977 & Max WS & $10-\mathrm{yr}$ & 05Мay2014 1218 & 30.85 & 256.91 & 258.79 & 1.3 & 27.83 & 49.44 & 1.88 \\
\hline 1191.977 & Max WS & $25-\mathrm{yr}$ & 05May2014 1218 & 38.65 & 256.91 & 258.99 & 1.27 & 38.56 & 60.11 & 2.08 \\
\hline 1191.977 & Max WS & $50-y r$ & 05Мay2014 1218 & 42.32 & 256.91 & 259.1 & 1.21 & 45.59 & 63.86 & 2.19 \\
\hline 1191.977 & Max WS & $100-\mathrm{yr}$ & 05May2014 1218 & 48.53 & 256.91 & 259.25 & 1.15 & 55.43 & 67.76 & 2.34 \\
\hline 1191.977 & Max WS & $500-\mathrm{yr}$ & 05Мау2014 1218 & 62.2 & 256.91 & 259.67 & 0.95 & 84.74 & 72.08 & 2.76 \\
\hline 1155.309 & Max WS & $2-y r$ & 05Мау2014 1218 & 16.07 & 257.11 & 258.37 & 1.15 & 17.37 & 40.27 & 1.26 \\
\hline 1155.309 & Max WS & $5-y r$ & 05May2014 1218 & 23.91 & 257.11 & 258.58 & 1.12 & 26.72 & 45.86 & 1.47 \\
\hline 1155.309 & Max WS & $10-\mathrm{yr}$ & 05May2014 1212 & 31.4 & 257.11 & 258.75 & 1.09 & 34.88 & 48.64 & 1.64 \\
\hline 1155.309 & Max WS & $25-y r$ & 05Мау2014 1218 & 38.52 & 257.11 & 258.96 & 0.99 & 45.3 & 52.4 & 1.85 \\
\hline 1155.309 & Max WS & $50-\mathrm{yr}$ & 05May2014 1218 & 42.13 & 257.11 & 259.08 & 0.93 & 51.48 & 54.51 & 1.97 \\
\hline 1155.309 & Max WS & $100-\mathrm{yr}$ & 05May2014 1218 & 48.21 & 257.11 & 259.23 & 0.9 & 59.97 & 57.07 & 2.12 \\
\hline 1155.309 & Max WS & $500-\mathrm{yr}$ & 05Мay2014 1218 & 61.37 & 257.11 & 259.65 & 0.8 & 86.53 & 66.28 & 2.54 \\
\hline 1124.025 & Max WS & $2-\mathrm{yr}$ & 05May2014 1218 & 15.95 & 255.94 & 256.85 & 3.15 & 5.06 & 8.64 & 0.91 \\
\hline 1124.025 & Max WS & $5-\mathrm{yr}$ & 05May2014 1218 & 23.85 & 255.94 & 257.05 & 3.48 & 6.85 & 9.46 & 1.11 \\
\hline 1124.025 & Max WS & $10-\mathrm{yr}$ & 05May2014 1218 & 30.84 & 255.94 & 257.18 & 3.79 & 8.14 & 10 & 1.24 \\
\hline 1124.025 & Max WS & $25-\mathrm{yr}$ & 05May2014 1212 & 38.02 & 255.94 & 257.31 & 4.02 & 9.45 & 10.53 & 1.37 \\
\hline 1124.025 & Max WS & $50-\mathrm{yr}$ & 05May2014 1218 & 41.95 & 255.94 & 257.34 & 4.27 & 9.82 & 10.67 & 1.4 \\
\hline 1124.025 & Max WS & $100-\mathrm{yr}$ & 05May2014 1218 & 47.92 & 255.94 & 257.41 & 4.53 & 10.58 & 10.96 & 1.47 \\
\hline 1124.025 & Max WS & $500-\mathrm{yr}$ & 05Мay2014 1218 & 60.6 & 255.94 & 257.51 & 5.22 & 11.61 & 11.35 & 1.57 \\
\hline 1083.982 & Max WS & $2-\mathrm{yr}$ & 05May2014 1218 & 15.89 & 255 & 256.49 & 1.4 & 11.35 & 11.26 & 1.49 \\
\hline 1083.982 & Max WS & $5-y r$ & 05May2014 1218 & 23.81 & 255 & 256.78 & 1.62 & 14.71 & 12.44 & 1.78 \\
\hline 1083.982 & Max WS & $10-\mathrm{yr}$ & 05May2014 1218 & 30.81 & 255 & 256.98 & 1.79 & 17.25 & 13.27 & 1.98 \\
\hline 1083.982 & Max WS & $25-\mathrm{yr}$ & 05Мay2014 1212 & 37.67 & 255 & 257.14 & 1.93 & 19.55 & 17.38 & 2.14 \\
\hline 1083.982 & Max WS & $50-\mathrm{yr}$ & 05May2014 1218 & 41.94 & 255 & 257.17 & 2.1 & 20.09 & 19.5 & 2.17 \\
\hline 1083.982 & Max WS & $100-\mathrm{yr}$ & 05May2014 1218 & 47.88 & 255 & 257.27 & 2.23 & 22.61 & 30.27 & 2.27 \\
\hline 1083.982 & Max WS & $500-y r$ & 05May2014 1218 & 60.59 & 255 & 257.4 & 2.51 & 26.72 & 32.94 & 2.4 \\
\hline 1018.257 & Max WS & $2-\mathrm{yr}$ & 05May2014 1218 & 15.78 & 254.8 & 255.97 & 2.04 & 7.74 & 9.94 & 1.17 \\
\hline 1018.257 & Max WS & $5-\mathrm{yr}$ & 05May2014 1218 & 23.71 & 254.8 & 256.21 & 2.31 & 10.27 & 10.86 & 1.41 \\
\hline 1018.257 & Max WS & $10-\mathrm{yr}$ & 05May2014 1218 & 30.73 & 254.8 & 256.39 & 2.51 & 12.36 & 16.19 & 1.59 \\
\hline 1018.257 & Max WS & $25-y r$ & 05Мау2014 1218 & 38.3 & 254.8 & 256.54 & 2.66 & 15.49 & 23.27 & 1.74 \\
\hline 1018.257 & Max WS & $50-\mathrm{yr}$ & 05May2014 1218 & 41.79 & 254.8 & 256.61 & 2.68 & 17.21 & 25.65 & 1.81 \\
\hline 1018.257 & Max WS & $100-\mathrm{yr}$ & 05Мау2014 1218 & 47.68 & 254.8 & 256.7 & 2.77 & 19.59 & 28.69 & 1.9 \\
\hline 1018.257 & Max WS & $500-\mathrm{yr}$ & 05May2014 1218 & 60.3 & 254.8 & 256.89 & 2.81 & 25.63 & 33.85 & 2.09 \\
\hline
\end{tabular}




\begin{tabular}{|c|c|c|c|c|c|c|c|c|c|c|}
\hline $\begin{array}{c}\text { River } \\
\text { Sta }\end{array}$ & Profile & Plan & Time at Max & $\begin{array}{c}\mathbf{Q} \\
\text { Total } \\
\left(\mathrm{m}^{3} / \mathbf{s}\right)\end{array}$ & $\begin{array}{c}\text { Min } \\
\text { Ch El } \\
(\mathbf{m})\end{array}$ & $\begin{array}{l}\text { W.S. } \\
\text { Elev } \\
(\mathbf{m})\end{array}$ & $\begin{array}{l}\text { Vel } \\
\text { Chnl } \\
(\mathrm{m} / \mathrm{s})\end{array}$ & $\begin{array}{l}\text { Flow } \\
\text { Area } \\
\left(\mathbf{m}^{2}\right) \\
\end{array}$ & $\begin{array}{c}\text { Top } \\
\text { Width } \\
\text { (m) }\end{array}$ & $\begin{array}{c}\text { Max Chl } \\
\text { Dpth } \\
(\mathrm{m})\end{array}$ \\
\hline 959.582 & Max WS & $2-y r$ & 05Мay2014 1218 & 15.65 & 254.42 & 255.65 & 1.51 & 10.37 & 12.29 & 1.23 \\
\hline 959.582 & Max WS & $5-y r$ & 05May2014 1218 & 23.55 & 254.42 & 255.92 & 1.7 & 13.88 & 15.48 & 1.5 \\
\hline 959.582 & Max WS & $10-\mathrm{yr}$ & 05May2014 1218 & 30.53 & 254.42 & 256.12 & 1.78 & 18.36 & 26.83 & 1.7 \\
\hline 959.582 & Max WS & $25-\mathrm{yr}$ & 05May2014 1218 & 37.95 & 254.42 & 256.33 & 1.78 & 24.63 & 35.26 & 1.91 \\
\hline 959.582 & Max WS & $50-\mathrm{yr}$ & 05May2014 1218 & 41.46 & 254.42 & 256.4 & 1.79 & 27.24 & 38.04 & 1.98 \\
\hline 959.582 & Max WS & $100-y r$ & 05May2014 1218 & 47.15 & 254.42 & 256.51 & 1.79 & 31.91 & 43.3 & 2.09 \\
\hline 959.582 & Max WS & $500-y r$ & 05Мау2014 1218 & 59.55 & 254.42 & 256.75 & 1.73 & 43.03 & 50.32 & 2.33 \\
\hline 917.744 & Max WS & $2-y r$ & 05May2014 1218 & 15.44 & 253.94 & 255.2 & 1.73 & 8.92 & 11.01 & 1.26 \\
\hline 917.744 & Max WS & $5-\mathrm{yr}$ & 05May2014 1218 & 23.32 & 253.94 & 255.48 & 1.92 & 12.17 & 12.26 & 1.54 \\
\hline 917.744 & Max WS & $10-\mathrm{yr}$ & 05May2014 1218 & 30.2 & 253.94 & 255.69 & 2.03 & 14.87 & 13.18 & 1.75 \\
\hline 917.744 & Max WS & $25-\mathrm{yr}$ & 05Мау2014 1218 & 37.55 & 253.94 & 255.91 & 2.1 & 18.32 & 20.21 & 1.97 \\
\hline 917.744 & Max WS & $50-y r$ & 05May2014 1218 & 40.96 & 253.94 & 256 & 2.11 & 20.41 & 23.05 & 2.06 \\
\hline & Max WS & $100-\mathrm{yr}$ & 05May2014 1218 & 46.32 & 253.94 & 256.15 & 2.08 & & 27.06 & 2.21 \\
\hline 917.744 & Max WS & $500-y r$ & 05May2014 1218 & 58.41 & 253.94 & 256.45 & 2 & 33.21 & 33.16 & 2.51 \\
\hline 885.843 & Max WS & $2-y r$ & 05May2014 1218 & 15.36 & 253.61 & 254.93 & 1.94 & 7.92 & 9.91 & 1.32 \\
\hline 885.843 & Max WS & $5-\mathrm{yr}$ & 05May2014 1218 & 23.24 & 253.61 & 255.23 & 2.09 & 11.09 & 11.05 & 1.62 \\
\hline 885.843 & Max WS & $10-\mathrm{yr}$ & 05May2014 1218 & 30.1 & 253.61 & 255.45 & 2.21 & 13.62 & 11.78 & 1.84 \\
\hline 885.843 & Max WS & $25-\mathrm{yr}$ & 05May2014 1218 & 37.43 & 253.61 & 255.68 & 2.28 & 16.45 & 12.56 & 2.07 \\
\hline 885.843 & Max WS & $50-y r$ & 05May2014 1218 & 40.78 & 253.61 & 255.78 & 2.31 & 17.88 & 17.59 & 2.17 \\
\hline 885.843 & Max WS & $100-\mathrm{yr}$ & 05May2014 1218 & 46.03 & 253.61 & 255.94 & 2.3 & 20.98 & 21.33 & 2.33 \\
\hline 885.843 & Max WS & $500-y r$ & 05May2014 1218 & 57.97 & 253.61 & 256.3 & 2.16 & 29.95 & 28.02 & 2.69 \\
\hline 831.018 & Max WS & $2-y r$ & 05May2014 1218 & 15.25 & 252.63 & 253.48 & 3.2 & 4.76 & 8.19 & 0.85 \\
\hline 831.018 & Max WS & $5-\mathrm{yr}$ & 05May2014 1218 & 23.12 & 252.63 & 253.66 & 3.61 & 6.4 & 9.16 & 1.03 \\
\hline 831.018 & Max WS & $10-y r$ & 05Мay2014 1218 & 29.99 & 252.63 & 253.79 & 3.95 & 7.6 & 9.79 & 1.16 \\
\hline 831.018 & Max WS & $25-\mathrm{yr}$ & 05Мау2014 1218 & 37.28 & 252.63 & 253.91 & 4.25 & 8.77 & 10.33 & 1.28 \\
\hline 831.018 & Max WS & $50-\mathrm{yr}$ & 05May2014 1218 & 40.61 & 252.63 & 253.96 & 4.36 & 9.32 & 10.57 & 1.33 \\
\hline 831.018 & Max WS & $100-\mathrm{yr}$ & 05Мay2014 1218 & 45.72 & 252.63 & 254.02 & 4.56 & 10.02 & 10.87 & 1.39 \\
\hline 831.018 & Max WS & $500-y r$ & 05May2014 1218 & 57.53 & 252.63 & 254.14 & 5.08 & 11.32 & 11.42 & 1.51 \\
\hline 794.448 & Max WS & $2-y r$ & 05May2014 1218 & 15.15 & 251.86 & 253.12 & 1.54 & 9.85 & 11.95 & 1.26 \\
\hline 794.448 & Max WS & $5-\mathrm{yr}$ & 05Мау2014 1218 & 23.03 & 251.86 & 253.38 & 1.75 & 13.14 & 13.42 & 1.52 \\
\hline 794.448 & Max WS & $10-y r$ & 05Мау2014 1218 & 29.9 & 251.86 & 253.57 & 1.88 & 15.88 & 14.36 & 1.71 \\
\hline 794.448 & Max WS & $25-y r$ & 05Мау2014 1218 & 37.17 & 251.86 & 253.75 & 2.01 & 18.55 & 15.27 & 1.89 \\
\hline 794.448 & Max WS & $50-\mathrm{yr}$ & 05May2014 1218 & 40.5 & 251.86 & 253.83 & 2.06 & 19.74 & 15.67 & 1.97 \\
\hline 794.448 & Max WS & $100-\mathrm{yr}$ & 05Мау2014 1218 & 45.58 & 251.86 & 253.93 & 2.15 & 21.32 & 16.18 & 2.07 \\
\hline 794.448 & Max WS & $500-y r$ & 05May2014 1218 & 57.38 & 251.86 & 254.13 & 2.37 & 24.62 & 17.19 & 2.27 \\
\hline
\end{tabular}




\begin{tabular}{|c|c|c|c|c|c|c|c|c|c|c|}
\hline $\begin{array}{l}\text { River } \\
\text { Sta }\end{array}$ & Profile & Plan & Time at Max & $\begin{array}{c}\mathbf{Q} \\
\text { Total } \\
\left(\mathbf{m}^{3} / \mathbf{s}\right)\end{array}$ & $\begin{array}{c}\text { Min } \\
\text { Ch El } \\
(\mathbf{m})\end{array}$ & $\begin{array}{l}\text { W.S. } \\
\text { Elev } \\
(m)\end{array}$ & $\begin{array}{c}\text { Vel } \\
\text { Chnl } \\
(\mathbf{m} / \mathbf{s})\end{array}$ & $\begin{array}{l}\text { Flow } \\
\text { Area } \\
\left(\mathbf{m}^{2}\right)\end{array}$ & $\begin{array}{c}\text { Top } \\
\text { Width } \\
\text { (m) }\end{array}$ & $\begin{array}{c}\text { Max Chl } \\
\text { Dpth } \\
\text { (m) }\end{array}$ \\
\hline 753.27 & Max WS & $2-y r$ & 05Мау2014 1218 & 15.02 & 251.5 & 252.57 & 2.28 & 6.59 & 9.89 & 1.07 \\
\hline 753.27 & Max WS & $5-\mathrm{yr}$ & 05May2014 1218 & 22.91 & 251.5 & 252.78 & 2.63 & 8.72 & 10.85 & 1.28 \\
\hline 753.27 & Max WS & $10-y r$ & 05Мау2014 1218 & 29.78 & 251.5 & 252.93 & 2.85 & 10.46 & 11.53 & 1.43 \\
\hline 753.27 & Max WS & $25-\mathrm{yr}$ & 05May2014 1218 & 37.04 & 251.5 & 253.07 & 3.07 & 12.06 & 12.13 & 1.57 \\
\hline 753.27 & Max WS & $50-\mathrm{yr}$ & 05May2014 1218 & 40.35 & 251.5 & 253.14 & 3.13 & 12.88 & 12.42 & 1.64 \\
\hline 753.27 & Max WS & $100-y r$ & 05May2014 1218 & 45.4 & 251.5 & 253.23 & 3.22 & 14.11 & 12.85 & 1.73 \\
\hline 753.27 & Max WS & $500-\mathrm{yr}$ & 05Мау2014 1218 & 57.14 & 251.5 & 253.48 & 3.27 & 17.46 & 13.95 & 1.98 \\
\hline 720.714 & Max WS & $2-\mathrm{yr}$ & 05Мay2014 1224 & 14.62 & 251.09 & 252.08 & 2.23 & 6.56 & 10.42 & 0.99 \\
\hline 720.714 & Max WS & $5-y r$ & 05May2014 1218 & 22.84 & 251.09 & 252.29 & 2.6 & 8.8 & 11.58 & 1.2 \\
\hline 720.714 & Max WS & $10-\mathrm{yr}$ & 05May2014 1218 & 29.7 & 251.09 & 252.44 & 2.78 & 10.68 & 12.47 & 1.35 \\
\hline 720.714 & Max WS & $25-y r$ & 05Мау2014 1218 & 36.96 & 251.09 & 252.57 & 3.02 & 12.24 & 13.1 & 1.48 \\
\hline 720.714 & Max WS & $50-\mathrm{yr}$ & 05May2014 1218 & 40.27 & 251.09 & 252.61 & 3.14 & 12.84 & 13.41 & 1.52 \\
\hline 720.714 & Max WS & $100-\mathrm{yr}$ & 05May2014 1218 & 45.3 & 251.09 & 252.68 & 3.3 & 13.73 & 13.86 & 1.59 \\
\hline 720.714 & Max WS & $500-\mathrm{yr}$ & 05Мay2014 1218 & 57 & 251.09 & 252.8 & 3.71 & 15.46 & 14.7 & 1.71 \\
\hline 673.556 & Max WS & $2-\mathrm{yr}$ & 05May2014 1224 & 14.6 & 250.52 & 251.88 & 0.65 & 22.39 & 27.34 & 1.36 \\
\hline 673.556 & Max WS & $5-\mathrm{yr}$ & 05May2014 1218 & 22.55 & 250.52 & 252.12 & 0.77 & 29.39 & 31.52 & 1.6 \\
\hline 673.556 & Max WS & $10-\mathrm{yr}$ & 05May2014 1218 & 29.36 & 250.52 & 252.3 & 0.83 & 35.54 & 34.76 & 1.78 \\
\hline 673.556 & Max WS & $25-\mathrm{yr}$ & 05May2014 1218 & 36.63 & 250.52 & 252.46 & 0.89 & 41.35 & 37.57 & 1.94 \\
\hline 673.556 & Max WS & $50-y r$ & 05May2014 1218 & 39.94 & 250.52 & 252.52 & 0.93 & 43.51 & 38.64 & 2 \\
\hline 673.556 & Max WS & $100-\mathrm{yr}$ & 05May2014 1218 & 44.93 & 250.52 & 252.6 & 0.98 & 46.69 & 40.23 & 2.08 \\
\hline 673.556 & Max WS & $500-y r$ & 05Мay2014 1218 & 56.66 & 250.52 & 252.75 & 1.09 & 53.1 & 43.25 & 2.23 \\
\hline 625.562 & Max WS & $2-\mathrm{yr}$ & 05May2014 1224 & 14.56 & 250.47 & 251.75 & 1.13 & 12.9 & 17.24 & 1.28 \\
\hline 625.562 & Max WS & $5-\mathrm{yr}$ & 05May2014 1218 & 22.18 & 250.47 & 251.96 & 1.32 & 16.92 & 20.64 & 1.49 \\
\hline 625.562 & Max WS & $10-y r$ & 05Мay2014 1218 & 28.88 & 250.47 & 252.15 & 1.42 & 20.96 & 23.96 & 1.68 \\
\hline 625.562 & Max WS & $25-y r$ & 05Мау2014 1218 & 36.18 & 250.47 & 252.3 & 1.52 & 25 & 26.79 & 1.83 \\
\hline 625.562 & Max WS & $50-\mathrm{yr}$ & 05May2014 1218 & 39.53 & 250.47 & 252.35 & 1.59 & 26.25 & 27.82 & 1.88 \\
\hline 625.562 & Max WS & $100-\mathrm{yr}$ & 05Мay2014 1218 & 44.48 & 250.47 & 252.42 & 1.69 & 28.16 & 29.06 & 1.95 \\
\hline 625.562 & Max WS & $500-y r$ & 05Мay2014 1218 & 56.22 & 250.47 & 252.53 & 1.93 & 31.63 & 30.87 & 2.06 \\
\hline 582.64 & Max WS & $2-y r$ & 05May2014 1224 & 14.54 & 250.01 & 250.8 & 2.56 & 5.67 & 13.58 & 0.79 \\
\hline 582.64 & Max WS & $5-\mathrm{yr}$ & 05Мау2014 1218 & 21.98 & 250.01 & 250.92 & 3.02 & 7.3 & 16.08 & 0.91 \\
\hline 582.64 & Max WS & $10-y r$ & 05Мау2014 1218 & 28.65 & 250.01 & 251.01 & 3.28 & 8.91 & 18.8 & 1 \\
\hline 582.64 & Max WS & $25-y r$ & 05Мау2014 1218 & 35.91 & 250.01 & 251.09 & 3.53 & 10.66 & 21.72 & 1.08 \\
\hline 582.64 & Max WS & $50-\mathrm{yr}$ & 05May2014 1218 & 39.32 & 250.01 & 251.12 & 3.67 & 11.33 & 22.73 & 1.11 \\
\hline 582.64 & Max WS & $100-\mathrm{yr}$ & 05Мау2014 1218 & 44.24 & 250.01 & 251.17 & 3.84 & 12.34 & 24.32 & 1.16 \\
\hline 582.64 & Max WS & $500-\mathrm{yr}$ & 05May2014 1224 & 55.92 & 250.01 & 251.28 & 4.05 & 15.3 & 27.98 & 1.27 \\
\hline
\end{tabular}




\begin{tabular}{|c|c|c|c|c|c|c|c|c|c|c|}
\hline $\begin{array}{l}\text { River } \\
\text { Sta }\end{array}$ & Profile & Plan & Time at Max & $\begin{array}{c}\mathbf{Q} \\
\text { Total } \\
\left(\mathrm{m}^{3} / \mathbf{s}\right) \\
\end{array}$ & $\begin{array}{c}\text { Min } \\
\text { Ch El } \\
(\mathbf{m}) \\
\end{array}$ & $\begin{array}{l}\text { W.S. } \\
\text { Elev } \\
(\mathbf{m})\end{array}$ & $\begin{array}{l}\text { Vel } \\
\text { Chnl } \\
(\mathbf{m} / \mathbf{s})\end{array}$ & $\begin{array}{c}\text { Flow } \\
\text { Area } \\
\left(\mathbf{m}^{2}\right) \\
\end{array}$ & $\begin{array}{c}\text { Top } \\
\text { Width } \\
\text { (m) }\end{array}$ & $\begin{array}{c}\text { Max Chl } \\
\text { Dpth } \\
(\mathbf{m})\end{array}$ \\
\hline 543.04 & Max WS & $2-y r$ & 05Мау2014 1224 & 14.52 & 249.4 & 250.32 & 1.28 & 11.49 & 20.78 & 0.92 \\
\hline 543.04 & Max WS & $5-\mathrm{yr}$ & 05May2014 1218 & 21.86 & 249.4 & 250.44 & 1.6 & 14.09 & 22.54 & 1.04 \\
\hline 543.04 & Max WS & $10-y r$ & 05Мау2014 1218 & 28.52 & 249.4 & 250.53 & 1.83 & 16.23 & 23.85 & 1.13 \\
\hline 543.04 & Max WS & $25-\mathrm{yr}$ & 05May2014 1218 & 35.75 & 249.4 & 250.61 & 2.08 & 18.11 & 24.95 & 1.21 \\
\hline 543.04 & Max WS & $50-\mathrm{yr}$ & 05Мау2014 1218 & 39.18 & 249.4 & 250.63 & 2.2 & 18.81 & 25.35 & 1.23 \\
\hline 543.04 & Max WS & $100-y r$ & 05Мау2014 1218 & 44.08 & 249.4 & 250.67 & 2.36 & 19.75 & 25.87 & 1.27 \\
\hline 543.04 & Max WS & $500-y r$ & 05Мау2014 1218 & 55.76 & 249.4 & 250.76 & 2.7 & 22.04 & 27.14 & 1.36 \\
\hline 496.118 & Max WS & $2-y r$ & 05Мay2014 1218 & 13.66 & 249.1 & 250.23 & 0.63 & 21.9 & 35.68 & 1.13 \\
\hline 496.118 & Max WS & $5-y r$ & 05May2014 1218 & 21.66 & 249.1 & 250.33 & 0.87 & 25.55 & 38.14 & 1.23 \\
\hline 496.118 & Max WS & $10-y r$ & 05Мау2014 1218 & 28.3 & 249.1 & 250.42 & 1.01 & 29.03 & 40.58 & 1.32 \\
\hline 496.118 & Max WS & $25-\mathrm{yr}$ & 05Мay2014 1218 & 35.56 & 249.1 & 250.49 & 1.16 & 31.85 & 42.45 & 1.39 \\
\hline 496.118 & Max WS & $50-y r$ & 05Мау2014 1218 & 39.04 & 249.1 & 250.51 & 1.25 & 32.7 & 42.96 & 1.41 \\
\hline 496.118 & Max WS & $100-y r$ & 05Мау2014 1218 & 43.93 & 249.1 & 250.53 & 1.37 & 33.77 & 43.6 & 1.43 \\
\hline 496.118 & Max WS & $500-y r$ & 05Мay2014 1218 & 55.56 & 249.1 & 250.6 & 1.6 & 36.79 & 45.44 & 1.5 \\
\hline 428.594 & Max WS & $2-y r$ & 05Маy2014 1224 & 14.48 & 248.79 & 249.32 & 1.99 & 7.53 & 26.9 & 0.53 \\
\hline 428.594 & Max WS & $5-\mathrm{yr}$ & 05Мay2014 1224 & 21.49 & 248.79 & 249.41 & 2.21 & 10.3 & 30.73 & 0.62 \\
\hline 428.594 & Max WS & $10-y r$ & 05Мay2014 1224 & 27.89 & 248.79 & 249.5 & 2.29 & 13.18 & 34.33 & 0.71 \\
\hline 428.594 & Max WS & $25-\mathrm{yr}$ & 05Мay2014 1224 & 34.86 & 248.79 & 249.58 & 2.38 & 16.07 & 37.57 & 0.79 \\
\hline 428.594 & Max WS & $50-\mathrm{yr}$ & 05Мay2014 1224 & 38.33 & 248.79 & 249.61 & 2.44 & 17.29 & 38.81 & 0.82 \\
\hline 428.594 & Max WS & $100-y r$ & 05Мay2014 1224 & 43.53 & 248.79 & 249.66 & 2.5 & 19.25 & 40.55 & 0.87 \\
\hline 428.594 & Max WS & $500-y r$ & 05Мay2014 1224 & 55.94 & 248.79 & 249.78 & 2.58 & 24.26 & 44.77 & 0.99 \\
\hline 389.142 & Max WS & $2-y r$ & 05Мay2014 1224 & 14.35 & 248.21 & 248.9 & 0.98 & 16.91 & 38.89 & 0.69 \\
\hline 389.142 & Max WS & $5-\mathrm{yr}$ & 05Мay2014 1224 & 21.42 & 248.21 & 249.06 & 1.05 & 23.63 & 42.78 & 0.85 \\
\hline 389.142 & Max WS & $10-y r$ & 05Мay2014 1224 & 27.83 & 248.21 & 249.19 & 1.13 & 28.99 & 45.5 & 0.98 \\
\hline 389.142 & Max WS & $25-\mathrm{yr}$ & 05Маy2014 1224 & 34.8 & 248.21 & 249.3 & 1.19 & 34.44 & 48.02 & 1.09 \\
\hline 389.142 & Max WS & $50-\mathrm{yr}$ & 05May2014 1224 & 38.28 & 248.21 & 249.36 & 1.22 & 37.1 & 49.17 & 1.15 \\
\hline 389.142 & Max WS & $100-\mathrm{yr}$ & 05Мау2014 1224 & 43.44 & 248.21 & 249.43 & 1.26 & 40.96 & 50.76 & 1.22 \\
\hline 389.142 & Max WS & $500-y r$ & 05May2014 1224 & 55.81 & 248.21 & 249.59 & 1.36 & 49.09 & 53.91 & 1.38 \\
\hline 343.978 & Max WS & $2-y r$ & 05Маy2014 1224 & 13.96 & 247.75 & 248.6 & 1.09 & 13.28 & 25.78 & 0.85 \\
\hline 343.978 & Max WS & $5-y r$ & 05Мay2014 1224 & 21.16 & 247.75 & 248.77 & 1.24 & 18.05 & 29.78 & 1.02 \\
\hline 343.978 & Max WS & $10-\mathrm{yr}$ & 05Мay2014 1224 & 27.62 & 247.75 & 248.89 & 1.37 & 21.82 & 32.64 & 1.14 \\
\hline 343.978 & Max WS & $25-y r$ & 05Мау2014 1224 & 34.6 & 247.75 & 249 & 1.49 & 25.53 & 34.93 & 1.25 \\
\hline 343.978 & Max WS & $50-\mathrm{yr}$ & 05Мay2014 1224 & 38.07 & 247.75 & 249.06 & 1.53 & 27.49 & 36.13 & 1.31 \\
\hline 343.978 & Max WS & $100-y r$ & 05Мау2014 1224 & 43.16 & 247.75 & 249.13 & 1.59 & 30.24 & 37.68 & 1.38 \\
\hline 343.978 & Max WS & $500-y r$ & 05Мау2014 1224 & 55.46 & 247.75 & 249.28 & 1.75 & 35.91 & 40.79 & 1.53 \\
\hline
\end{tabular}




\begin{tabular}{|c|c|c|c|c|c|c|c|c|c|c|}
\hline $\begin{array}{l}\text { River } \\
\text { Sta }\end{array}$ & Profile & Plan & Time at Max & $\begin{array}{c}\mathbf{Q} \\
\text { Total } \\
\left(\mathrm{m}^{3} / \mathbf{s}\right) \\
\end{array}$ & $\begin{array}{c}\text { Min } \\
\text { Ch El } \\
(\mathbf{m}) \\
\end{array}$ & $\begin{array}{l}\text { W.S. } \\
\text { Elev } \\
(\mathbf{m})\end{array}$ & $\begin{array}{c}\text { Vel } \\
\text { Chnl } \\
(\mathbf{m} / \mathbf{s})\end{array}$ & $\begin{array}{c}\text { Flow } \\
\text { Area } \\
\left(\mathbf{m}^{2}\right) \\
\end{array}$ & $\begin{array}{c}\text { Top } \\
\text { Width } \\
\text { (m) }\end{array}$ & $\begin{array}{c}\text { Max Chl } \\
\text { Dpth } \\
(\mathbf{m})\end{array}$ \\
\hline 318.111 & Max WS & $2-y r$ & 05Мау2014 1224 & 13.86 & 247.65 & 248.48 & 1.23 & 11.48 & 23.43 & 0.83 \\
\hline 318.111 & Max WS & $5-y r$ & 05Мау2014 1224 & 21.08 & 247.65 & 248.65 & 1.39 & 15.89 & 27.3 & 1 \\
\hline 318.111 & Max WS & $10-y r$ & 05Мау2014 1224 & 27.56 & 247.65 & 248.76 & 1.54 & 19.08 & 29.79 & 1.11 \\
\hline 318.111 & Max WS & $25-\mathrm{yr}$ & 05Мay2014 1224 & 34.54 & 247.65 & 248.87 & 1.67 & 22.37 & 31.73 & 1.22 \\
\hline 318.111 & Max WS & $50-\mathrm{yr}$ & 05Мау2014 1224 & 38 & 247.65 & 248.92 & 1.71 & 24.16 & 32.86 & 1.27 \\
\hline 318.111 & Max WS & $100-\mathrm{yr}$ & 05Мау2014 1224 & 43.09 & 247.65 & 248.99 & 1.78 & 26.48 & 34.32 & 1.34 \\
\hline 318.111 & Max WS & $500-\mathrm{yr}$ & 05Мау2014 1224 & 55.36 & 247.65 & 249.13 & 1.96 & 31.35 & 37.06 & 1.48 \\
\hline 284.899 & Max WS & $2-y r$ & 05Мay2014 1224 & 13.73 & 247.49 & 248.35 & 1.04 & 13.16 & 25.67 & 0.86 \\
\hline 284.899 & Max WS & $5-y r$ & 05Мау2014 1224 & 20.97 & 247.49 & 248.54 & 1.16 & 18.29 & 29.66 & 1.05 \\
\hline 284.899 & Max WS & $10-y r$ & 05Мау2014 1224 & 27.47 & 247.49 & 248.65 & 1.29 & 21.82 & 32.4 & 1.16 \\
\hline 284.899 & Max WS & $25-\mathrm{yr}$ & 05Мay2014 1224 & 34.46 & 247.49 & 248.76 & 1.41 & 25.49 & 34.9 & 1.27 \\
\hline 284.899 & Max WS & $50-y r$ & 05Мау2014 1224 & 37.91 & 247.49 & 248.82 & 1.44 & 27.51 & 36 & 1.33 \\
\hline 284.899 & Max WS & $100-\mathrm{yr}$ & 05Мау2014 1224 & 43 & 247.49 & 248.89 & 1.51 & 30.05 & 37.34 & 1.4 \\
\hline 284.899 & Max WS & $500-\mathrm{yr}$ & 05Мay2014 1224 & 55.23 & 247.49 & 249.02 & 1.68 & 35.33 & 40.15 & 1.53 \\
\hline 244.681 & Max WS & $2-y r$ & 05Мay2014 1230 & 13.46 & 247.05 & 247.91 & 1.39 & 9.71 & 19.64 & 0.87 \\
\hline 244.681 & Max WS & $5-y r$ & 05Мay2014 1224 & 20.72 & 247.05 & 248.1 & 1.52 & 13.66 & 23.7 & 1.05 \\
\hline 244.681 & Max WS & $10-y r$ & 05Мay2014 1224 & 27.23 & 247.05 & 248.21 & 1.65 & 16.5 & 26.4 & 1.16 \\
\hline 244.681 & Max WS & $25-y r$ & 05Мay2014 1224 & 34.22 & 247.05 & 248.34 & 1.69 & 20.2 & 29.45 & 1.29 \\
\hline 244.681 & Max WS & $50-\mathrm{yr}$ & 05Мay2014 1224 & 37.67 & 247.05 & 248.4 & 1.72 & 21.94 & 30.8 & 1.35 \\
\hline 244.681 & Max WS & $100-\mathrm{yr}$ & 05Мay2014 1224 & 42.75 & 247.05 & 248.46 & 1.81 & 23.72 & 32.11 & 1.41 \\
\hline 244.681 & Max WS & $500-\mathrm{yr}$ & 05May2014 1224 & 54.95 & 247.05 & 248.59 & 1.98 & 28.26 & 35.59 & 1.54 \\
\hline 214.499 & Max WS & $2-y r$ & 05May2014 1230 & 13.41 & 246.61 & 247.86 & 0.64 & 21.68 & 31 & 1.25 \\
\hline 214.499 & Max WS & $5-\mathrm{yr}$ & 05May2014 1224 & 20.58 & 246.61 & 248.04 & 0.79 & 27.89 & 35.41 & 1.43 \\
\hline 214.499 & Max WS & $10-y r$ & 05May2014 1224 & 27.09 & 246.61 & 248.17 & 0.91 & 32.42 & 38.28 & 1.56 \\
\hline 214.499 & Max WS & $25-\mathrm{yr}$ & 05Мay2014 1224 & 34.06 & 246.61 & 248.31 & 0.99 & 38.11 & 41.48 & 1.7 \\
\hline 214.499 & Max WS & $50-\mathrm{yr}$ & 05May2014 1224 & 37.51 & 246.61 & 248.37 & 1.03 & 40.68 & 42.89 & 1.76 \\
\hline 214.499 & Max WS & $100-\mathrm{yr}$ & 05Мay2014 1224 & 42.62 & 246.61 & 248.43 & 1.11 & 43.34 & 44.24 & 1.82 \\
\hline 214.499 & Max WS & $500-\mathrm{yr}$ & 05May2014 1224 & 54.82 & 246.61 & 248.58 & 1.25 & 50.06 & 47.47 & 1.97 \\
\hline 214.498 & Max WS & $2-y r$ & 05Мay2014 1230 & 13.33 & 246.61 & 247.31 & 1.66 & 8.05 & 19.07 & 0.7 \\
\hline 214.498 & Max WS & $5-\mathrm{yr}$ & 05May2014 1224 & 20.27 & 246.61 & 247.44 & 1.9 & 10.64 & 21.86 & 0.83 \\
\hline 214.498 & Max WS & $10-\mathrm{yr}$ & 05May2014 1224 & 26.79 & 246.61 & 247.54 & 2.07 & 12.93 & 24.09 & 0.93 \\
\hline 214.498 & Max WS & $25-\mathrm{yr}$ & 05May2014 1224 & 33.75 & 246.61 & 247.63 & 2.23 & 15.22 & 26.12 & 1.02 \\
\hline 214.498 & Max WS & $50-\mathrm{yr}$ & 05May2014 1224 & 37.16 & 246.61 & 247.68 & 2.28 & 16.47 & 27.2 & 1.07 \\
\hline 214.498 & Max WS & $100-\mathrm{yr}$ & 05Мау2014 1224 & 42.33 & 246.61 & 247.73 & 2.39 & 17.93 & 28.36 & 1.12 \\
\hline 214.498 & Max WS & $500-\mathrm{yr}$ & 05May2014 1224 & 54.51 & 246.61 & 247.85 & 2.6 & 21.5 & 30.88 & 1.24 \\
\hline
\end{tabular}




\begin{tabular}{|c|c|c|c|c|c|c|c|c|c|c|}
\hline $\begin{array}{c}\text { River } \\
\text { Sta }\end{array}$ & Profile & Plan & Time at Max & $\begin{array}{c}\mathbf{Q} \\
\text { Total } \\
\left(\mathbf{m}^{3} / \mathbf{s}\right) \\
\end{array}$ & $\begin{array}{c}\text { Min } \\
\text { Ch El } \\
(\mathbf{m}) \\
\end{array}$ & $\begin{array}{l}\text { W.S. } \\
\text { Elev } \\
(\mathrm{m})\end{array}$ & $\begin{array}{c}\text { Vel } \\
\text { Chnl } \\
(\mathbf{m} / \mathbf{s}) \\
\end{array}$ & $\begin{array}{l}\text { Flow } \\
\text { Area } \\
\left(\mathbf{m}^{2}\right)\end{array}$ & $\begin{array}{c}\text { Top } \\
\text { Width } \\
\text { (m) }\end{array}$ & $\begin{array}{c}\text { Max Chl } \\
\text { Dpth } \\
\text { (m) }\end{array}$ \\
\hline 147.881 & Max WS & $2-y r$ & 05Мау2014 1230 & 13.25 & 245.82 & 246.6 & 1.45 & 9.11 & 19.86 & 0.78 \\
\hline 147.881 & Max WS & $5-\mathrm{yr}$ & 05May2014 1230 & 19.72 & 245.82 & 246.77 & 1.54 & 12.78 & 23.38 & 0.95 \\
\hline 147.881 & Max WS & $10-y r$ & 05Мау2014 1224 & 26.5 & 245.82 & 246.92 & 1.61 & 16.46 & 26.5 & 1.1 \\
\hline 147.881 & Max WS & $25-y r$ & 05Мау2014 1224 & 33.47 & 245.82 & 247.05 & 1.68 & 20.05 & 29.3 & 1.23 \\
\hline 147.881 & Max WS & $50-\mathrm{yr}$ & 05May2014 1224 & 36.85 & 245.82 & 247.11 & 1.71 & 21.81 & 30.67 & 1.29 \\
\hline 147.881 & Max WS & $100-y r$ & 05May2014 1224 & 41.9 & 245.82 & 247.2 & 1.74 & 24.73 & 32.86 & 1.38 \\
\hline 147.881 & Max WS & $500-\mathrm{yr}$ & 05Мау2014 1224 & 54.01 & 245.82 & 247.41 & 1.77 & 32.21 & 38.33 & 1.59 \\
\hline 79.942 & Max WS & $2-\mathrm{yr}$ & 05May2014 1230 & 13.09 & 245.12 & 246.21 & 1.11 & 11.81 & 18.19 & 1.09 \\
\hline 79.942 & Max WS & $5-y r$ & 05May2014 1230 & 19.71 & 245.12 & 246.43 & 1.22 & 16.13 & 21.54 & 1.31 \\
\hline 79.942 & Max WS & $10-\mathrm{yr}$ & 05May2014 1224 & 26.04 & 245.12 & 246.61 & 1.29 & 20.3 & 24.18 & 1.49 \\
\hline 79.942 & Max WS & $25-y r$ & 05Мау2014 1224 & 33.04 & 245.12 & 246.79 & 1.35 & 24.89 & 26.85 & 1.67 \\
\hline 79.942 & Max WS & $50-\mathrm{yr}$ & 05May2014 1224 & 36.39 & 245.12 & 246.86 & 1.38 & 26.94 & 28.11 & 1.74 \\
\hline 79.942 & Max WS & $100-\mathrm{yr}$ & 05May2014 1224 & 41.23 & 245.12 & 246.98 & 1.4 & 30.43 & 30.52 & 1.86 \\
\hline 79.942 & Max WS & $500-\mathrm{yr}$ & 05Мay2014 1224 & 53.06 & 245.12 & 247.25 & 1.44 & 40.19 & 46.83 & 2.13 \\
\hline 53.415 & Max WS & $2-\mathrm{yr}$ & 05May2014 1230 & 13.05 & 244.76 & 245.52 & 2.65 & 4.92 & 10.21 & 0.76 \\
\hline 53.415 & Max WS & $5-\mathrm{yr}$ & 05May2014 1230 & 19.7 & 244.76 & 245.66 & 3.06 & 6.43 & 11.4 & 0.9 \\
\hline 53.415 & Max WS & $10-\mathrm{yr}$ & 05May2014 1224 & 25.91 & 244.76 & 245.78 & 3.29 & 7.87 & 12.43 & 1.02 \\
\hline 53.415 & Max WS & $25-\mathrm{yr}$ & 05May2014 1224 & 32.93 & 244.76 & 245.89 & 3.56 & 9.26 & 13.34 & 1.13 \\
\hline 53.415 & Max WS & $50-y r$ & 05May2014 1224 & 36.26 & 244.76 & 245.93 & 3.68 & 9.85 & 13.71 & 1.17 \\
\hline 53.415 & Max WS & $100-\mathrm{yr}$ & 05May2014 1224 & 41.07 & 244.76 & 245.98 & 3.89 & 10.57 & 14.16 & 1.22 \\
\hline 53.415 & Max WS & $500-y r$ & 05Мay2014 1224 & 52.8 & 244.76 & 246.09 & 4.34 & 12.18 & 15.07 & 1.33 \\
\hline 13.63 & Max WS & $2-\mathrm{yr}$ & 05May2014 1230 & 13 & 243.93 & 244.78 & 2.03 & 6.4 & 11.5 & 0.85 \\
\hline 13.63 & Max WS & $5-\mathrm{yr}$ & 05May2014 1230 & 19.69 & 243.93 & 244.96 & 2.27 & 8.67 & 13.09 & 1.03 \\
\hline 13.63 & Max WS & $10-y r$ & 05Мау2014 1224 & 25.79 & 243.93 & 245.1 & 2.43 & 10.6 & 14.42 & 1.17 \\
\hline 13.63 & Max WS & $25-y r$ & 05Мау2014 1224 & 32.8 & 243.93 & 245.24 & 2.58 & 12.85 & 19.78 & 1.31 \\
\hline 13.63 & Max WS & $50-\mathrm{yr}$ & 05May2014 1224 & 36.13 & 243.93 & 245.3 & 2.63 & 14.15 & 23.26 & 1.37 \\
\hline 13.63 & Max WS & $100-\mathrm{yr}$ & 05Мау2014 1224 & 40.91 & 243.93 & 245.37 & 2.72 & 15.82 & 26.92 & 1.44 \\
\hline 13.63 & Max WS & $500-\mathrm{yr}$ & 05May2014 1224 & 52.62 & 243.93 & 245.5 & 2.91 & 19.97 & 34.92 & 1.57 \\
\hline
\end{tabular}

Table 27: Unsteady GLD (Post mining) cross-sectional properties

\begin{tabular}{|c|c|c|c|c|c|c|c|c|c|c|}
\hline $\begin{array}{l}\text { River } \\
\text { Sta }\end{array}$ & Profile & Plan & Time of Max & $\begin{array}{c}\mathbf{Q} \\
\text { Total } \\
\left(\mathbf{m}^{3} / \mathbf{s}\right)\end{array}$ & $\begin{array}{c}\text { Min } \\
\text { Ch EI } \\
\text { (m) }\end{array}$ & $\begin{array}{l}\text { W.S. } \\
\text { Elev } \\
(\mathbf{m})\end{array}$ & $\begin{array}{l}\text { Vel } \\
\text { Chnl } \\
(\mathbf{m} / \mathbf{s})\end{array}$ & $\begin{array}{l}\text { Flow } \\
\text { Area } \\
\left(\mathbf{m}^{2}\right)\end{array}$ & $\begin{array}{c}\text { Top } \\
\text { Width } \\
\text { (m) }\end{array}$ & $\begin{array}{c}\text { Max Chl } \\
\text { Dpth } \\
\text { (m) }\end{array}$ \\
\hline 2097.011 & Max WS & $2-y r$ & 05Мау2014 1212 & 4.28 & 264.87 & 265.82 & 0.69 & 6.22 & 10 & 0.95 \\
\hline 2097.011 & Max WS & $5-\mathrm{yr}$ & 05Мay2014 1212 & 8.62 & 264.87 & 266.16 & 0.87 & 9.92 & 11.84 & 1.29 \\
\hline 2097.011 & Max WS & $10-\mathrm{yr}$ & 05Маy2014 1212 & 13.19 & 264.87 & 266.42 & 0.99 & 13.26 & 13.62 & 1.55 \\
\hline
\end{tabular}




\begin{tabular}{|c|c|c|c|c|c|c|c|c|c|c|}
\hline $\begin{array}{l}\text { River } \\
\text { Sta }\end{array}$ & Profile & Plan & Time of Max & $\begin{array}{c}\mathbf{Q} \\
\text { Total } \\
\left(\mathrm{m}^{3} / \mathbf{s}\right)\end{array}$ & $\begin{array}{c}\text { Min } \\
\text { Ch El } \\
\text { (m) }\end{array}$ & $\begin{array}{l}\text { W.S. } \\
\text { Elev } \\
(\mathbf{m})\end{array}$ & $\begin{array}{c}\text { Vel } \\
\text { Chnl } \\
(\mathbf{m} / \mathbf{s})\end{array}$ & $\begin{array}{c}\text { Flow } \\
\text { Area } \\
\left(\mathbf{m}^{2}\right) \\
\end{array}$ & $\begin{array}{c}\text { Top } \\
\text { Width } \\
\text { (m) }\end{array}$ & $\begin{array}{c}\text { Max Chl } \\
\text { Dpth } \\
\text { (m) } \\
\end{array}$ \\
\hline 2097.011 & Max WS & $25-\mathrm{yr}$ & 05May2014 1212 & 18.63 & 264.87 & 266.68 & 1.09 & 17.12 & 15.33 & 1.81 \\
\hline 2097.011 & Max WS & $50-\mathrm{yr}$ & 05Мay2014 1212 & 21.54 & 264.87 & 266.81 & 1.13 & 19.04 & 16.06 & 1.94 \\
\hline 2097.011 & Max WS & $100-y r$ & 05Маy2014 1212 & 26.63 & 264.87 & 267.02 & 1.18 & 22.67 & 19.28 & 2.15 \\
\hline 2097.011 & Max WS & $500-\mathrm{yr}$ & 05Мay2014 1212 & 38.64 & 264.87 & 267.42 & 1.24 & 34.42 & 38.6 & 2.55 \\
\hline 2052.742 & Max WS & $2-\mathrm{yr}$ & 05May2014 1212 & 4.23 & 264.51 & 265.03 & 2.05 & 2.06 & 6.7 & 0.52 \\
\hline 2052.742 & Max WS & $5-\mathrm{yr}$ & 05May2014 1212 & 8.54 & 264.51 & 265.19 & 2.6 & 3.28 & 7.82 & 0.68 \\
\hline 2052.742 & Max WS & $10-\mathrm{yr}$ & 05May2014 1212 & 13.09 & 264.51 & 265.33 & 2.99 & 4.38 & 8.68 & 0.82 \\
\hline 2052.742 & Max WS & $25-\mathrm{yr}$ & 05Мау2014 1212 & 18.51 & 264.51 & 265.44 & 3.43 & 5.4 & 9.25 & 0.93 \\
\hline 2052.742 & Max WS & $50-y r$ & 05May2014 1212 & 21.41 & 264.51 & 265.5 & 3.59 & 5.97 & 9.56 & 0.99 \\
\hline 2052.742 & Max WS & $100-\mathrm{yr}$ & 05May2014 1212 & 26.43 & 264.51 & 265.59 & 3.87 & 6.82 & 10 & 1.08 \\
\hline 2052.742 & Max WS & $500-y r$ & 05Маy2014 1212 & 38.33 & 264.51 & 265.73 & 4.6 & 8.34 & 10.74 & 1.22 \\
\hline 2009.086 & Max WS & $2-\mathrm{yr}$ & 05Мay2014 1212 & 4.16 & 263.84 & 264.31 & 1.2 & 3.47 & 10.81 & 0.47 \\
\hline 2009.086 & Max WS & $5-\mathrm{yr}$ & 05Мay2014 1212 & 8.47 & 263.84 & 264.5 & 1.48 & 5.74 & 12.79 & 0.66 \\
\hline 2009.086 & Max WS & $10-\mathrm{yr}$ & 05Мay2014 1212 & 13.01 & 263.84 & 264.67 & 1.64 & 7.95 & 14.43 & 0.83 \\
\hline 2009.086 & Max WS & $25-\mathrm{yr}$ & 05May2014 1212 & 18.41 & 263.84 & 264.83 & 1.77 & 10.4 & 16.02 & 0.99 \\
\hline 2009.086 & Max WS & $50-\mathrm{yr}$ & 05May2014 1212 & 21.31 & 263.84 & 264.89 & 1.85 & 11.51 & 16.67 & 1.05 \\
\hline 2009.086 & Max WS & $100-y r$ & 05May2014 1212 & 26.33 & 263.84 & 264.99 & 2 & 13.15 & 17.54 & 1.15 \\
\hline 2009.086 & Max WS & $500-y \mathrm{r}$ & 05Мay2014 1212 & 38.19 & 263.84 & 265.21 & 2.22 & 17.28 & 19.54 & 1.37 \\
\hline 1964.49 & Max WS & $2-y r$ & 05May2014 1212 & 4.07 & 263.35 & 263.74 & 1.37 & 2.97 & 11.37 & 0.39 \\
\hline 1964.49 & Max WS & $5-y r$ & 05Маy2014 1212 & 8.38 & 263.35 & 263.89 & 1.73 & 4.84 & 13.58 & 0.54 \\
\hline 1964.49 & Max WS & $10-\mathrm{yr}$ & 05Мay2014 1212 & 12.89 & 263.35 & 264.01 & 1.98 & 6.5 & 15.31 & 0.66 \\
\hline 1964.49 & Max WS & $25-\mathrm{yr}$ & 05Мay2014 1212 & 18.26 & 263.35 & 264.13 & 2.16 & 8.43 & 17.22 & 0.78 \\
\hline 1964.49 & Max WS & $50-y r$ & 05Мay2014 1212 & 21.19 & 263.35 & 264.17 & 2.3 & 9.23 & 17.98 & 0.82 \\
\hline 1964.49 & Max WS & $100-y r$ & 05May2014 1212 & 26.18 & 263.35 & 264.25 & 2.46 & 10.62 & 19.24 & 0.9 \\
\hline 1964.49 & Max WS & $500-y r$ & 05May2014 1212 & 37.99 & 263.35 & 264.41 & 2.71 & 14 & 21.88 & 1.06 \\
\hline 1925.761 & Max WS & $2-\mathrm{yr}$ & 05May2014 1212 & 3.98 & 263.04 & 263.4 & 0.87 & 4.56 & 19.46 & 0.36 \\
\hline 1925.761 & Max WS & $5-\mathrm{yr}$ & 05May2014 1212 & 8.24 & 263.04 & 263.58 & 0.95 & 8.7 & 26.59 & 0.54 \\
\hline 1925.761 & Max WS & $10-\mathrm{yr}$ & 05Мay2014 1212 & 12.71 & 263.04 & 263.71 & 1.05 & 12.47 & 32.76 & 0.67 \\
\hline 1925.761 & Max WS & $25-\mathrm{yr}$ & 05Мay2014 1212 & 17.99 & 263.04 & 263.84 & 1.12 & 17.23 & 38.96 & 0.8 \\
\hline 1925.761 & Max WS & $50-y r$ & 05Маy2014 1212 & 20.89 & 263.04 & 263.91 & 1.15 & 19.91 & 41.96 & 0.87 \\
\hline 1925.761 & Max WS & $100-y r$ & 05May2014 1212 & 25.87 & 263.04 & 264 & 1.21 & 23.88 & 45.48 & 0.96 \\
\hline 1925.761 & Max WS & $500-y r$ & 05May2014 1212 & 37.53 & 263.04 & 264.18 & 1.32 & 33.28 & 56.64 & 1.14 \\
\hline 1874.546 & Max WS & $2-\mathrm{yr}$ & 05Маy2014 1218 & 3.85 & 262.4 & 263.01 & 0.67 & 5.72 & 16.04 & 0.61 \\
\hline 1874.546 & Max WS & $5-\mathrm{yr}$ & 05May2014 1212 & 7.72 & 262.4 & 263.18 & 0.89 & 8.71 & 19.86 & 0.78 \\
\hline 1874.546 & Max WS & $10-\mathrm{yr}$ & 05Маy2014 1212 & 12.14 & 262.4 & 263.29 & 1.09 & 11.1 & 22.26 & 0.89 \\
\hline
\end{tabular}




\begin{tabular}{|c|c|c|c|c|c|c|c|c|c|c|}
\hline $\begin{array}{l}\text { River } \\
\text { Sta }\end{array}$ & Profile & Plan & Time of Max & $\begin{array}{c}\mathbf{Q} \\
\text { Total } \\
\left(\mathrm{m}^{3} / \mathbf{s}\right)\end{array}$ & $\begin{array}{c}\text { Min } \\
\text { Ch El } \\
\text { (m) }\end{array}$ & $\begin{array}{l}\text { W.S. } \\
\text { Elev } \\
(\mathbf{m})\end{array}$ & $\begin{array}{c}\text { Vel } \\
\text { Chnl } \\
(\mathbf{m} / \mathbf{s})\end{array}$ & $\begin{array}{c}\text { Flow } \\
\text { Area } \\
\left(\mathbf{m}^{2}\right) \\
\end{array}$ & $\begin{array}{c}\text { Top } \\
\text { Width } \\
\text { (m) }\end{array}$ & $\begin{array}{c}\text { Max Chl } \\
\text { Dpth } \\
\text { (m) } \\
\end{array}$ \\
\hline 1874.546 & Max WS & $25-y r$ & 05May2014 1212 & 17.21 & 262.4 & 263.42 & 1.23 & 14.05 & 25.19 & 1.02 \\
\hline 1874.546 & Max WS & $50-\mathrm{yr}$ & 05Мay2014 1212 & 20.05 & 262.4 & 263.46 & 1.33 & 15.18 & 26.18 & 1.06 \\
\hline 1874.546 & Max WS & $100-\mathrm{yr}$ & 05Маy2014 1212 & 24.96 & 262.4 & 263.53 & 1.49 & 17.03 & 28.04 & 1.13 \\
\hline 1874.546 & Max WS & $500-y r$ & 05Мay2014 1212 & 36.22 & 262.4 & 263.68 & 1.75 & 21.6 & 32.78 & 1.28 \\
\hline 1828.159 & Max WS & $2-\mathrm{yr}$ & 05May2014 1218 & 3.82 & 262.13 & 262.55 & 1.27 & 3.02 & 12.92 & 0.42 \\
\hline 1828.159 & Max WS & $5-\mathrm{yr}$ & 05May2014 1218 & 7.55 & 262.13 & 262.68 & 1.52 & 4.98 & 16.82 & 0.55 \\
\hline 1828.159 & Max WS & $10-\mathrm{yr}$ & 05May2014 1212 & 11.9 & 262.13 & 262.82 & 1.59 & 7.48 & 20.52 & 0.69 \\
\hline 1828.159 & Max WS & $25-\mathrm{yr}$ & 05Мау2014 1212 & 16.93 & 262.13 & 262.93 & 1.71 & 9.89 & 23.6 & 0.8 \\
\hline 1828.159 & Max WS & $50-y r$ & 05May2014 1212 & 19.79 & 262.13 & 262.97 & 1.8 & 10.99 & 24.73 & 0.84 \\
\hline 1828.159 & Max WS & $100-y r$ & 05May2014 1212 & 24.64 & 262.13 & 263.05 & 1.91 & 13.01 & 26.68 & 0.92 \\
\hline 1828.159 & Max WS & $500-y r$ & 05Маy2014 1212 & 35.78 & 262.13 & 263.22 & 2.07 & 17.82 & 31.09 & 1.09 \\
\hline 1788.723 & Max WS & $2-y r$ & 05Мay2014 1218 & 3.76 & 261.54 & 262.28 & 0.45 & 8.42 & 21.95 & 0.74 \\
\hline 1788.723 & Max WS & $5-y r$ & 05May2014 1218 & 7.53 & 261.54 & 262.44 & 0.61 & 12.36 & 26.01 & 0.9 \\
\hline 1788.723 & Max WS & $10-\mathrm{yr}$ & 05Мay2014 1212 & 11.58 & 261.54 & 262.6 & 0.7 & 16.78 & 29.72 & 1.06 \\
\hline 1788.723 & Max WS & $25-\mathrm{yr}$ & 05May2014 1212 & 16.6 & 261.54 & 262.73 & 0.83 & 20.66 & 32.38 & 1.19 \\
\hline 1788.723 & Max WS & $50-\mathrm{yr}$ & 05May2014 1212 & 19.41 & 261.54 & 262.79 & 0.88 & 22.83 & 33.76 & 1.25 \\
\hline 1788.723 & Max WS & $100-y r$ & 05May2014 1212 & 24.22 & 261.54 & 262.89 & 0.97 & 26.4 & 36 & 1.35 \\
\hline 1788.723 & Max WS & $500-y r$ & 05Мay2014 1212 & 35.23 & 261.54 & 263.09 & 1.11 & 34.01 & 39.84 & 1.55 \\
\hline 1742.556 & Max WS & $2-y r$ & 05May2014 1218 & 3.64 & 261.5 & 262.23 & 0.43 & 8.38 & 19.6 & 0.73 \\
\hline 1742.556 & Max WS & $5-y r$ & 05Мay2014 1218 & 7.49 & 261.5 & 262.37 & 0.66 & 11.32 & 22.52 & 0.87 \\
\hline 1742.556 & Max WS & $10-\mathrm{yr}$ & 05Мay2014 1212 & 11.13 & 261.5 & 262.52 & 0.74 & 15.01 & 25.75 & 1.02 \\
\hline 1742.556 & Max WS & $25-\mathrm{yr}$ & 05Мay2014 1212 & 16.19 & 261.5 & 262.63 & 0.91 & 17.88 & 27.87 & 1.13 \\
\hline 1742.556 & Max WS & $50-y r$ & 05Мay2014 1212 & 18.88 & 261.5 & 262.7 & 0.97 & 19.7 & 29.14 & 1.2 \\
\hline 1742.556 & Max WS & $100-y r$ & 05May2014 1212 & 23.65 & 261.5 & 262.79 & 1.08 & 22.48 & 30.84 & 1.29 \\
\hline 1742.556 & Max WS & $500-\mathrm{yr}$ & 05May2014 1212 & 34.53 & 261.5 & 262.98 & 1.26 & 28.73 & 34.62 & 1.48 \\
\hline 1695.655 & Max WS & $2-y r$ & 05Мay2014 1224 & 3.6 & 261.28 & 261.74 & 1.38 & 2.6 & 9.54 & 0.46 \\
\hline 1695.655 & Max WS & $5-\mathrm{yr}$ & 05May2014 1218 & 7.44 & 261.28 & 261.9 & 1.68 & 4.42 & 11.97 & 0.62 \\
\hline 1695.655 & Max WS & $10-\mathrm{yr}$ & 05Мay2014 1218 & 11.51 & 261.28 & 262.08 & 1.72 & 6.7 & 14.16 & 0.8 \\
\hline 1695.655 & Max WS & $25-\mathrm{yr}$ & 05Мay2014 1218 & 16.11 & 261.28 & 262.24 & 1.77 & 9.08 & 16.41 & 0.96 \\
\hline 1695.655 & Max WS & $50-y r$ & 05Маy2014 1218 & 18.6 & 261.28 & 262.32 & 1.77 & 10.58 & 18.21 & 1.04 \\
\hline 1695.655 & Max WS & $100-\mathrm{yr}$ & 05May2014 1218 & 22.9 & 261.28 & 262.44 & 1.81 & 12.91 & 21.17 & 1.16 \\
\hline 1695.655 & Max WS & $500-\mathrm{yr}$ & 05May2014 1218 & 33.09 & 261.28 & 262.71 & 1.84 & 19.67 & 30.15 & 1.43 \\
\hline 1651.05 & Max WS & $2-\mathrm{yr}$ & 05Маy2014 1224 & 3.58 & 260.78 & 261.37 & 0.64 & 5.55 & 14.42 & 0.59 \\
\hline 1651.05 & Max WS & $5-y r$ & 05Мay2014 1224 & 6.9 & 260.78 & 261.64 & 0.71 & 9.79 & 17.03 & 0.86 \\
\hline 1651.05 & Max WS & $10-\mathrm{yr}$ & 05Маy2014 1218 & 11.36 & 260.78 & 261.88 & 0.81 & 14.06 & 19.23 & 1.1 \\
\hline
\end{tabular}




\begin{tabular}{|c|c|c|c|c|c|c|c|c|c|c|}
\hline $\begin{array}{l}\text { River } \\
\text { Sta }\end{array}$ & Profile & Plan & Time of Max & $\begin{array}{c}\mathbf{Q} \\
\text { Total } \\
\left(\mathrm{m}^{3} / \mathbf{s}\right)\end{array}$ & $\begin{array}{c}\text { Min } \\
\text { Ch El } \\
(\mathbf{m})\end{array}$ & $\begin{array}{l}\text { W.S. } \\
\text { Elev } \\
(m)\end{array}$ & $\begin{array}{c}\text { Vel } \\
\text { Chnl } \\
(\mathrm{m} / \mathrm{s})\end{array}$ & $\begin{array}{l}\text { Flow } \\
\text { Area } \\
\left(\mathbf{m}^{2}\right)\end{array}$ & $\begin{array}{c}\text { Top } \\
\text { Width } \\
\text { (m) }\end{array}$ & $\begin{array}{c}\text { Max Chl } \\
\text { Dpth } \\
\text { (m) }\end{array}$ \\
\hline 1651.05 & Max WS & $25-y r$ & 05Мay2014 1218 & 15.98 & 260.78 & 262.09 & 0.87 & 18.4 & 21.15 & 1.31 \\
\hline 1651.05 & Max WS & $50-\mathrm{yr}$ & 05Мay2014 1218 & 18.45 & 260.78 & 262.19 & 0.89 & 20.63 & 22.03 & 1.41 \\
\hline 1651.05 & Max WS & $100-\mathrm{yr}$ & 05Маy2014 1218 & 22.76 & 260.78 & 262.35 & 0.94 & 24.11 & 23.36 & 1.57 \\
\hline 1651.05 & Max WS & $500-\mathrm{yr}$ & 05Мay2014 1218 & 32.89 & 260.78 & 262.65 & 1.04 & 31.65 & 26.17 & 1.87 \\
\hline 1617.21 & Max WS & $2-y r$ & 05Мay2014 1230 & 3.44 & 260.56 & 261.31 & 0.62 & 5.52 & 11.77 & 0.75 \\
\hline 1617.21 & Max WS & $5-y r$ & 05Маy2014 1224 & 6.89 & 260.56 & 261.58 & 0.76 & 9.1 & 14.23 & 1.02 \\
\hline 1617.21 & Max WS & $10-y r$ & 05Мay2014 1218 & 11.2 & 260.56 & 261.81 & 0.88 & 12.67 & 16.39 & 1.25 \\
\hline 1617.21 & Max WS & $25-\mathrm{yr}$ & 05Мay2014 1218 & 15.84 & 260.56 & 262.03 & 0.97 & 16.38 & 18.25 & 1.47 \\
\hline 1617.21 & Max WS & $50-y r$ & 05Мay2014 1218 & 18.3 & 260.56 & 262.13 & 1 & 18.32 & 19.13 & 1.57 \\
\hline 1617.21 & Max WS & $100-\mathrm{yr}$ & 05Мау2014 1218 & 22.63 & 260.56 & 262.28 & 1.06 & 21.3 & 20.23 & 1.72 \\
\hline 1617.21 & Max WS & $500-\mathrm{yr}$ & 05Маy2014 1218 & 32.76 & 260.56 & 262.58 & 1.18 & 27.69 & 22.25 & 2.02 \\
\hline 1577.381 & Max WS & $2-y r$ & 05Маy2014 1230 & 3.44 & 260.48 & 261.28 & 0.2 & 17.08 & 27.29 & 0.8 \\
\hline 1577.381 & Max WS & $5-\mathrm{yr}$ & 05Мау2014 1224 & 6.87 & 260.48 & 261.57 & 0.27 & 25.18 & 30.12 & 1.09 \\
\hline 1577.381 & Max WS & $10-y r$ & 05Мay2014 1218 & 10.94 & 260.48 & 261.8 & 0.34 & 32.59 & 32.22 & 1.32 \\
\hline 1577.381 & Max WS & $25-y r$ & 05May2014 1218 & 15.6 & 260.48 & 262.02 & 0.39 & 39.95 & 34.48 & 1.54 \\
\hline 1577.381 & Max WS & $50-y r$ & 05Мay2014 1218 & 18.06 & 260.48 & 262.13 & 0.41 & 43.66 & 35.2 & 1.65 \\
\hline 1577.381 & Max WS & $100-\mathrm{yr}$ & 05Мay2014 1218 & 22.41 & 260.48 & 262.28 & 0.46 & 49.35 & 38.81 & 1.8 \\
\hline 1577.381 & Max WS & $500-\mathrm{yr}$ & 05Маy2014 1218 & 32.51 & 260.48 & 262.59 & 0.53 & 62.91 & 51.47 & 2.11 \\
\hline 1542.946 & Max WS & $2-y r$ & 05Мay2014 1230 & 3.43 & 260.49 & 261.15 & 1.15 & 2.98 & 6.27 & 0.66 \\
\hline 1542.946 & Max WS & $5-\mathrm{yr}$ & 05Мay2014 1224 & 6.85 & 260.49 & 261.39 & 1.48 & 4.61 & 7.38 & 0.9 \\
\hline 1542.946 & Max WS & $10-y r$ & 05Мay2014 1218 & 10.75 & 260.49 & 261.59 & 1.76 & 6.11 & 8.29 & 1.1 \\
\hline 1542.946 & Max WS & $25-\mathrm{yr}$ & 05May2014 1218 & 15.43 & 260.49 & 261.77 & 2 & 7.73 & 9.17 & 1.28 \\
\hline 1542.946 & Max WS & $50-\mathrm{yr}$ & 05Мay2014 1218 & 17.9 & 260.49 & 261.86 & 2.1 & 8.54 & 9.56 & 1.37 \\
\hline 1542.946 & Max WS & $100-\mathrm{yr}$ & 05Мау2014 1218 & 22.25 & 260.49 & 261.99 & 2.25 & 9.88 & 10.15 & 1.5 \\
\hline 1542.946 & Max WS & $500-\mathrm{yr}$ & 05May2014 1218 & 32.33 & 260.49 & 262.25 & 2.56 & 12.61 & 11 & 1.76 \\
\hline 1504.079 & Max WS & $2-y r$ & 05Мау2014 1230 & 3.43 & 260.31 & 260.89 & 1.21 & 2.84 & 7.85 & 0.58 \\
\hline 1504.079 & Max WS & $5-y r$ & 05Мay2014 1224 & 6.84 & 260.31 & 261.12 & 1.45 & 4.7 & 8.87 & 0.81 \\
\hline 1504.079 & Max WS & $10-\mathrm{yr}$ & 05May2014 1218 & 10.67 & 260.31 & 261.3 & 1.68 & 6.36 & 9.68 & 0.99 \\
\hline 1504.079 & Max WS & $25-\mathrm{yr}$ & 05May2014 1218 & 15.36 & 260.31 & 261.46 & 1.91 & 8.03 & 10.44 & 1.15 \\
\hline 1504.079 & Max WS & $50-\mathrm{yr}$ & 05Мау2014 1218 & 17.82 & 260.31 & 261.54 & 2 & 8.9 & 10.81 & 1.23 \\
\hline 1504.079 & Max WS & $100-y r$ & 05Мay2014 1218 & 22.18 & 260.31 & 261.66 & 2.17 & 10.21 & 11.35 & 1.35 \\
\hline 1504.079 & Max WS & $500-\mathrm{yr}$ & 05Мay2014 1218 & 32.26 & 260.31 & 261.86 & 2.58 & 12.52 & 12.24 & 1.55 \\
\hline 1467.659 & Max WS & $2-\mathrm{yr}$ & 05Маy2014 1224 & 3.38 & 260.12 & 260.72 & 0.88 & 3.82 & 9.31 & 0.6 \\
\hline 1467.659 & Max WS & $5-\mathrm{yr}$ & 05Маy2014 1224 & 6.82 & 260.12 & 260.93 & 1.14 & 5.99 & 10.85 & 0.81 \\
\hline 1467.659 & Max WS & $10-\mathrm{yr}$ & 05May2014 1218 & 10.57 & 260.12 & 261.13 & 1.28 & 8.23 & 12.32 & 1.01 \\
\hline
\end{tabular}




\begin{tabular}{|c|c|c|c|c|c|c|c|c|c|c|}
\hline $\begin{array}{l}\text { River } \\
\text { Sta }\end{array}$ & Profile & Plan & Time of Max & $\begin{array}{c}\mathbf{Q} \\
\text { Total } \\
\left(\mathrm{m}^{3} / \mathbf{s}\right) \\
\end{array}$ & $\begin{array}{c}\text { Min } \\
\text { Ch El } \\
\text { (m) }\end{array}$ & $\begin{array}{l}\text { W.S. } \\
\text { Elev } \\
(\mathbf{m})\end{array}$ & $\begin{array}{c}\begin{array}{c}\text { Vel } \\
\text { Chnl } \\
(\mathbf{m} / \mathbf{s})\end{array} \\
\end{array}$ & $\begin{array}{c}\text { Flow } \\
\text { Area } \\
\left(\mathbf{m}^{2}\right)\end{array}$ & $\begin{array}{c}\text { Top } \\
\text { Width } \\
\text { (m) }\end{array}$ & $\begin{array}{c}\text { Max Chl } \\
\text { Dpth } \\
(\mathbf{m}) \\
\end{array}$ \\
\hline 1467.659 & Max WS & $25-y r$ & 05May2014 1218 & 15.26 & 260.12 & 261.29 & 1.47 & 10.38 & 13.77 & 1.17 \\
\hline 1467.659 & Max WS & $50-y r$ & 05May2014 1218 & 17.72 & 260.12 & 261.39 & 1.51 & 11.72 & 14.62 & 1.27 \\
\hline 1467.659 & Max WS & $100-y r$ & 05May2014 1218 & 22.1 & 260.12 & 261.49 & 1.66 & 13.32 & 15.59 & 1.37 \\
\hline 1467.659 & Max WS & $500-y r$ & 05May2014 1218 & 32.19 & 260.12 & 261.7 & 1.93 & 16.72 & 17.59 & 1.58 \\
\hline 1425.307 & Max WS & $2-\mathrm{yr}$ & 05May2014 1230 & 3.43 & 259.66 & 260.17 & 1.62 & 2.11 & 6.96 & 0.51 \\
\hline 1425.307 & Max WS & $5-y r$ & 05May2014 1224 & 6.79 & 259.66 & 260.36 & 1.91 & 3.55 & 8.52 & 0.7 \\
\hline 1425.307 & Max WS & $10-\mathrm{yr}$ & 05Мay2014 1218 & 10.47 & 259.66 & 260.49 & 2.18 & 4.81 & 9.7 & 0.83 \\
\hline 1425.307 & Max WS & $25-\mathrm{yr}$ & 05May2014 1218 & 15.14 & 259.66 & 260.66 & 2.32 & 6.52 & 11.27 & 1 \\
\hline 1425.307 & Max WS & $50-\mathrm{yr}$ & 05Мay2014 1218 & 17.59 & 259.66 & 260.73 & 2.4 & 7.33 & 12.03 & 1.07 \\
\hline 1425.307 & Max WS & $100-y r$ & 05May2014 1218 & 21.99 & 259.66 & 260.83 & 2.56 & 8.59 & 13.11 & 1.17 \\
\hline 1425.307 & Max WS & $500-y r$ & 05May2014 1218 & 32.07 & 259.66 & 261.05 & 2.75 & 11.8 & 17.28 & 1.39 \\
\hline 1392.843 & Max WS & $2-\mathrm{yr}$ & 05Мay2014 1230 & 3.43 & 259.14 & 259.68 & 1.49 & 2.31 & 7.4 & 0.54 \\
\hline 1392.843 & Max WS & $5-y r$ & 05May2014 1224 & 6.77 & 259.14 & 259.87 & 1.73 & 3.92 & 8.98 & 0.73 \\
\hline 1392.843 & Max WS & $10-\mathrm{yr}$ & 05Мay2014 1224 & 10.42 & 259.14 & 260.03 & 1.94 & 5.36 & 9.83 & 0.89 \\
\hline 1392.843 & Max WS & $25-\mathrm{yr}$ & 05Мay2014 1218 & 15.06 & 259.14 & 260.18 & 2.17 & 6.95 & 10.69 & 1.04 \\
\hline 1392.843 & Max WS & $50-y r$ & 05May2014 1218 & 17.5 & 259.14 & 260.27 & 2.22 & 7.87 & 11.15 & 1.13 \\
\hline 1392.843 & Max WS & $100-y r$ & 05May2014 1218 & 21.91 & 259.14 & 260.38 & 2.38 & 9.21 & 11.88 & 1.24 \\
\hline 1392.843 & Max WS & $500-y r$ & 05May2014 1218 & 31.96 & 259.14 & 260.64 & 2.55 & 12.53 & 14.35 & 1.5 \\
\hline 1358.799 & Max WS & $2-y r$ & 05Мay2014 1230 & 3.42 & 258.63 & 259.14 & 1.57 & 2.18 & 7.28 & 0.51 \\
\hline 1358.799 & Max WS & $5-y r$ & 05May2014 1224 & 6.75 & 258.63 & 259.3 & 1.93 & 3.49 & 8.43 & 0.67 \\
\hline 1358.799 & Max WS & $10-\mathrm{yr}$ & 05Маy2014 1224 & 10.42 & 258.63 & 259.45 & 2.19 & 4.77 & 9.29 & 0.82 \\
\hline 1358.799 & Max WS & $25-\mathrm{yr}$ & 05Мay2014 1218 & 14.99 & 258.63 & 259.59 & 2.43 & 6.17 & 10.16 & 0.96 \\
\hline 1358.799 & Max WS & $50-\mathrm{yr}$ & 05Мay2014 1218 & 17.41 & 258.63 & 259.66 & 2.54 & 6.85 & 10.56 & 1.03 \\
\hline 1358.799 & Max WS & $100-y r$ & 05May2014 1218 & 21.83 & 258.63 & 259.77 & 2.7 & 8.07 & 11.25 & 1.14 \\
\hline 1358.799 & Max WS & $500-y r$ & 05May2014 1218 & 31.86 & 258.63 & 259.98 & 2.99 & 10.66 & 12.59 & 1.35 \\
\hline 1329.439 & Max WS & $2-\mathrm{yr}$ & 05May2014 1224 & 3.3 & 258.21 & 258.73 & 1.34 & 2.47 & 7.69 & 0.52 \\
\hline 1329.439 & Max WS & $5-\mathrm{yr}$ & 05May2014 1224 & 6.73 & 258.21 & 258.95 & 1.55 & 4.34 & 9.22 & 0.74 \\
\hline 1329.439 & Max WS & $10-\mathrm{yr}$ & 05Мау2014 1224 & 10.41 & 258.21 & 259.1 & 1.8 & 5.77 & 10.11 & 0.89 \\
\hline 1329.439 & Max WS & $25-\mathrm{yr}$ & 05Мау2014 1218 & 14.89 & 258.21 & 259.29 & 1.91 & 7.8 & 11.26 & 1.08 \\
\hline 1329.439 & Max WS & $50-\mathrm{yr}$ & 05May2014 1218 & 17.34 & 258.21 & 259.37 & 2 & 8.67 & 11.72 & 1.15 \\
\hline 1329.439 & Max WS & $100-y r$ & 05May2014 1218 & 21.75 & 258.21 & 259.51 & 2.09 & 10.38 & 12.57 & 1.3 \\
\hline 1329.439 & Max WS & $500-\mathrm{yr}$ & 05May2014 1218 & 31.77 & 258.21 & 259.8 & 2.23 & 14.29 & 14.26 & 1.59 \\
\hline 1302.462 & Max WS & $2-\mathrm{yr}$ & 05Мay2014 1224 & 3.29 & 257.76 & 258.63 & 0.43 & 7.67 & 12.71 & 0.87 \\
\hline 1302.462 & Max WS & $5-\mathrm{yr}$ & 05May2014 1224 & 6.69 & 257.76 & 258.88 & 0.6 & 11.1 & 14.31 & 1.12 \\
\hline 1302.462 & Max WS & $10-\mathrm{yr}$ & 05May2014 1224 & 10.4 & 257.76 & 259.05 & 0.76 & 13.63 & 15.44 & 1.29 \\
\hline
\end{tabular}




\begin{tabular}{|c|c|c|c|c|c|c|c|c|c|c|}
\hline $\begin{array}{l}\text { River } \\
\text { Sta }\end{array}$ & Profile & Plan & Time of Max & $\begin{array}{c}\mathbf{Q} \\
\text { Total } \\
\left(\mathrm{m}^{3} / \mathbf{s}\right) \\
\end{array}$ & $\begin{array}{l}\text { Min } \\
\text { Ch El } \\
\text { (m) }\end{array}$ & $\begin{array}{l}\text { W.S. } \\
\text { Elev } \\
(\mathbf{m})\end{array}$ & $\begin{array}{c}\begin{array}{c}\text { Vel } \\
\text { Chnl } \\
(\mathbf{m} / \mathbf{s})\end{array} \\
\end{array}$ & $\begin{array}{c}\text { Flow } \\
\text { Area } \\
\left(\mathbf{m}^{2}\right) \\
\end{array}$ & $\begin{array}{c}\text { Top } \\
\text { Width } \\
\text { (m) }\end{array}$ & $\begin{array}{c}\text { Max Chl } \\
\text { Dpth } \\
(\mathbf{m}) \\
\end{array}$ \\
\hline 1302.462 & Max WS & $25-\mathrm{yr}$ & 05May2014 1218 & 14.75 & 257.76 & 259.27 & 0.86 & 17.1 & 16.85 & 1.51 \\
\hline 1302.462 & Max WS & $50-y r$ & 05May2014 1218 & 17.22 & 257.76 & 259.36 & 0.93 & 18.6 & 17.43 & 1.6 \\
\hline 1302.462 & Max WS & $100-y r$ & 05May2014 1218 & 21.61 & 257.76 & 259.51 & 1.01 & 21.44 & 18.51 & 1.75 \\
\hline 1302.462 & Max WS & $500-y r$ & 05May2014 1218 & 31.64 & 257.76 & 259.84 & 1.14 & 27.82 & 20.82 & 2.08 \\
\hline 1264.23 & Max WS & $2-\mathrm{yr}$ & 05May2014 1236 & 3.38 & 257.59 & 258.15 & 1.35 & 2.5 & 7.22 & 0.56 \\
\hline 1264.23 & Max WS & $5-y r$ & 05May2014 1230 & 6.53 & 257.59 & 258.35 & 1.59 & 4.1 & 8.68 & 0.76 \\
\hline 1264.23 & Max WS & $10-\mathrm{yr}$ & 05Мay2014 1224 & 10.36 & 257.59 & 258.52 & 1.83 & 5.65 & 9.53 & 0.93 \\
\hline 1264.23 & Max WS & $25-\mathrm{yr}$ & 05May2014 1224 & 14.59 & 257.59 & 258.67 & 2.04 & 7.14 & 10.28 & 1.08 \\
\hline 1264.23 & Max WS & $50-\mathrm{yr}$ & 05Мay2014 1224 & 16.82 & 257.59 & 258.74 & 2.14 & 7.87 & 10.62 & 1.15 \\
\hline 1264.23 & Max WS & $100-y r$ & 05May2014 1218 & 21.26 & 257.59 & 258.85 & 2.35 & 9.06 & 11.16 & 1.26 \\
\hline 1264.23 & Max WS & $500-y r$ & 05May2014 1218 & 31.29 & 257.59 & 259.06 & 2.72 & 11.52 & 12.2 & 1.47 \\
\hline 1230.005 & Max WS & $2-\mathrm{yr}$ & 05Мay2014 1236 & 3.38 & 257.24 & 258 & 0.68 & 4.93 & 9.66 & 0.76 \\
\hline 1230.005 & Max WS & $5-y r$ & 05May2014 1230 & 6.53 & 257.24 & 258.19 & 0.94 & 6.93 & 10.89 & 0.95 \\
\hline 1230.005 & Max WS & $10-\mathrm{yr}$ & 05Мay2014 1224 & 10.32 & 257.24 & 258.39 & 1.12 & 9.2 & 12.13 & 1.15 \\
\hline 1230.005 & Max WS & $25-\mathrm{yr}$ & 05Мay2014 1224 & 14.57 & 257.24 & 258.54 & 1.32 & 11.06 & 13.07 & 1.3 \\
\hline 1230.005 & Max WS & $50-y r$ & 05May2014 1224 & 16.81 & 257.24 & 258.61 & 1.39 & 12.08 & 13.54 & 1.37 \\
\hline 1230.005 & Max WS & $100-y r$ & 05May2014 1224 & 20.69 & 257.24 & 258.73 & 1.51 & 13.68 & 14.16 & 1.49 \\
\hline 1230.005 & Max WS & $500-y \mathrm{r}$ & 05May2014 1218 & 31.15 & 257.24 & 258.94 & 1.86 & 16.76 & 15.27 & 1.7 \\
\hline 1191.977 & Max WS & $2-y r$ & 05Мay2014 1236 & 3.36 & 256.91 & 257.93 & 0.38 & 8.76 & 12.8 & 1.02 \\
\hline 1191.977 & Max WS & $5-y r$ & 05May2014 1230 & 6.51 & 256.91 & 258.09 & 0.59 & 10.97 & 13.87 & 1.18 \\
\hline 1191.977 & Max WS & $10-\mathrm{yr}$ & 05Маy2014 1224 & 10.21 & 256.91 & 258.27 & 0.75 & 13.56 & 15.03 & 1.36 \\
\hline 1191.977 & Max WS & $25-\mathrm{yr}$ & 05Мay2014 1224 & 14.49 & 256.91 & 258.39 & 0.94 & 15.41 & 15.86 & 1.48 \\
\hline 1191.977 & Max WS & $50-\mathrm{yr}$ & 05Мay2014 1224 & 16.74 & 256.91 & 258.46 & 1.02 & 16.55 & 20.32 & 1.55 \\
\hline 1191.977 & Max WS & $100-y r$ & 05May2014 1224 & 20.67 & 256.91 & 258.56 & 1.12 & 19.19 & 28.79 & 1.65 \\
\hline 1191.977 & Max WS & $500-y r$ & 05May2014 1224 & 29.76 & 256.91 & 258.77 & 1.29 & 26.69 & 47.93 & 1.86 \\
\hline 1155.309 & Max WS & $2-\mathrm{yr}$ & 05Маy2014 1236 & 3.35 & 257.11 & 257.87 & 0.7 & 4.85 & 12.19 & 0.76 \\
\hline 1155.309 & Max WS & $5-\mathrm{yr}$ & 05May2014 1230 & 6.5 & 257.11 & 258.01 & 1.02 & 7.02 & 21.97 & 0.9 \\
\hline 1155.309 & Max WS & $10-\mathrm{yr}$ & 05Мау2014 1224 & 10.1 & 257.11 & 258.18 & 1.05 & 11.53 & 28.46 & 1.07 \\
\hline 1155.309 & Max WS & $25-\mathrm{yr}$ & 05Мау2014 1224 & 14.42 & 257.11 & 258.31 & 1.13 & 15.42 & 31.97 & 1.2 \\
\hline 1155.309 & Max WS & $50-\mathrm{yr}$ & 05May2014 1224 & 16.68 & 257.11 & 258.39 & 1.17 & 18.18 & 41.21 & 1.28 \\
\hline 1155.309 & Max WS & $100-y r$ & 05May2014 1224 & 20.63 & 257.11 & 258.5 & 1.13 & 23.03 & 44.1 & 1.39 \\
\hline 1155.309 & Max WS & $500-\mathrm{yr}$ & 05May2014 1224 & 29.72 & 257.11 & 258.73 & 1.07 & 33.7 & 48.19 & 1.62 \\
\hline 1124.025 & Max WS & $2-\mathrm{yr}$ & 05Мay2014 1236 & 3.34 & 255.94 & 256.41 & 1.97 & 1.7 & 6.59 & 0.47 \\
\hline 1124.025 & Max WS & $5-\mathrm{yr}$ & 05May2014 1230 & 6.47 & 255.94 & 256.55 & 2.48 & 2.61 & 7.33 & 0.61 \\
\hline 1124.025 & Max WS & $10-\mathrm{yr}$ & 05May2014 1224 & 9.91 & 255.94 & 256.68 & 2.7 & 3.67 & 7.92 & 0.74 \\
\hline
\end{tabular}




\begin{tabular}{|c|c|c|c|c|c|c|c|c|c|c|}
\hline $\begin{array}{l}\text { River } \\
\text { Sta }\end{array}$ & Profile & Plan & Time of Max & $\begin{array}{c}\mathbf{Q} \\
\text { Total } \\
\left(\mathrm{m}^{3} / \mathbf{s}\right) \\
\end{array}$ & $\begin{array}{c}\text { Min } \\
\text { Ch El } \\
\text { (m) }\end{array}$ & $\begin{array}{l}\text { W.S. } \\
\text { Elev } \\
(\mathbf{m})\end{array}$ & $\begin{array}{c}\begin{array}{c}\text { Vel } \\
\text { Chnl } \\
(\mathbf{m} / \mathbf{s})\end{array} \\
\end{array}$ & $\begin{array}{c}\text { Flow } \\
\text { Area } \\
\left(\mathbf{m}^{2}\right) \\
\end{array}$ & $\begin{array}{c}\text { Top } \\
\text { Width } \\
\text { (m) }\end{array}$ & $\begin{array}{c}\text { Max Chl } \\
\text { Dpth } \\
(\mathbf{m}) \\
\end{array}$ \\
\hline 1124.025 & Max WS & $25-y r$ & 05May2014 1224 & 14.29 & 255.94 & 256.81 & 3.05 & 4.69 & 8.46 & 0.87 \\
\hline 1124.025 & Max WS & $50-y r$ & 05May2014 1224 & 16.57 & 255.94 & 256.87 & 3.18 & 5.21 & 8.71 & 0.93 \\
\hline 1124.025 & Max WS & $100-\mathrm{yr}$ & 05May2014 1224 & 20.54 & 255.94 & 256.98 & 3.33 & 6.17 & 9.17 & 1.04 \\
\hline 1124.025 & Max WS & $500-y r$ & 05May2014 1224 & 29.68 & 255.94 & 257.16 & 3.75 & 7.91 & 9.9 & 1.22 \\
\hline 1083.982 & Max WS & $2-\mathrm{yr}$ & 05May2014 1236 & 3.33 & 255 & 255.8 & 0.73 & 4.56 & 8.36 & 0.8 \\
\hline 1083.982 & Max WS & $5-y r$ & 05May2014 1230 & 6.46 & 255 & 256.04 & 0.96 & 6.7 & 9.43 & 1.04 \\
\hline 1083.982 & Max WS & $10-\mathrm{yr}$ & 05Мay2014 1230 & 9.83 & 255 & 256.22 & 1.16 & 8.46 & 10.16 & 1.22 \\
\hline 1083.982 & Max WS & $25-\mathrm{yr}$ & 05Мay2014 1224 & 14.24 & 255 & 256.43 & 1.34 & 10.64 & 11 & 1.43 \\
\hline 1083.982 & Max WS & $50-\mathrm{yr}$ & 05Мay2014 1224 & 16.53 & 255 & 256.52 & 1.42 & 11.63 & 11.35 & 1.52 \\
\hline 1083.982 & Max WS & $100-y r$ & 05May2014 1224 & 20.5 & 255 & 256.67 & 1.53 & 13.37 & 11.98 & 1.67 \\
\hline 1083.982 & Max WS & $500-y r$ & 05May2014 1224 & 29.65 & 255 & 256.94 & 1.77 & 16.78 & 13.12 & 1.94 \\
\hline 1018.257 & Max WS & $2-y r$ & 05Мay2014 1236 & 3.31 & 254.8 & 255.37 & 1.32 & 2.51 & 7.31 & 0.57 \\
\hline 1018.257 & Max WS & $5-y r$ & 05May2014 1230 & 6.42 & 254.8 & 255.59 & 1.52 & 4.22 & 8.49 & 0.79 \\
\hline 1018.257 & Max WS & $10-\mathrm{yr}$ & 05Мay2014 1230 & 9.83 & 254.8 & 255.74 & 1.75 & 5.6 & 9.09 & 0.94 \\
\hline 1018.257 & Max WS & $25-\mathrm{yr}$ & 05Мay2014 1224 & 14.13 & 254.8 & 255.92 & 1.96 & 7.2 & 9.74 & 1.11 \\
\hline 1018.257 & Max WS & $50-y r$ & 05Мay2014 1224 & 16.42 & 254.8 & 255.99 & 2.06 & 7.96 & 10.03 & 1.19 \\
\hline 1018.257 & Max WS & $100-\mathrm{yr}$ & 05May2014 1224 & 20.41 & 254.8 & 256.12 & 2.19 & 9.3 & 10.53 & 1.32 \\
\hline 1018.257 & Max WS & $500-y r$ & 05May2014 1224 & 29.57 & 254.8 & 256.37 & 2.46 & 12.06 & 14.59 & 1.57 \\
\hline 959.582 & Max WS & $2-y r$ & 05Мay2014 1236 & 3.29 & 254.42 & 255.02 & 0.91 & 3.62 & 8.99 & 0.6 \\
\hline 959.582 & Max WS & $5-y r$ & 05May2014 1230 & 6.37 & 254.42 & 255.23 & 1.13 & 5.64 & 10.23 & 0.81 \\
\hline 959.582 & Max WS & $10-\mathrm{yr}$ & 05Мау2014 1230 & 9.81 & 254.42 & 255.41 & 1.3 & 7.55 & 11.26 & 0.99 \\
\hline 959.582 & Max WS & $25-\mathrm{yr}$ & 05Маy2014 1224 & 14.01 & 254.42 & 255.59 & 1.46 & 9.61 & 12.02 & 1.17 \\
\hline 959.582 & Max WS & $50-\mathrm{yr}$ & 05Мay2014 1224 & 16.3 & 254.42 & 255.67 & 1.52 & 10.69 & 12.41 & 1.25 \\
\hline 959.582 & Max WS & $100-\mathrm{yr}$ & 05May2014 1224 & 20.29 & 254.42 & 255.82 & 1.62 & 12.52 & 13.03 & 1.4 \\
\hline 959.582 & Max WS & $500-\mathrm{yr}$ & 05May2014 1224 & 29.4 & 254.42 & 256.1 & 1.77 & 17.64 & 25.67 & 1.68 \\
\hline 917.744 & Max WS & $2-\mathrm{yr}$ & 05Маy2014 1242 & 3.29 & 253.94 & 254.54 & 1.23 & 2.66 & 7.77 & 0.6 \\
\hline 917.744 & Max WS & $5-\mathrm{yr}$ & 05May2014 1236 & 6.3 & 253.94 & 254.76 & 1.39 & 4.55 & 8.88 & 0.82 \\
\hline 917.744 & Max WS & $10-\mathrm{yr}$ & 05Мау2014 1230 & 9.77 & 253.94 & 254.97 & 1.52 & 6.44 & 9.88 & 1.03 \\
\hline 917.744 & Max WS & $25-\mathrm{yr}$ & 05Мау2014 1224 & 13.83 & 253.94 & 255.14 & 1.69 & 8.19 & 10.69 & 1.2 \\
\hline 917.744 & Max WS & $50-\mathrm{yr}$ & 05May2014 1224 & 16.12 & 253.94 & 255.23 & 1.74 & 9.25 & 11.15 & 1.29 \\
\hline 917.744 & Max WS & $100-y r$ & 05May2014 1224 & 20.11 & 253.94 & 255.37 & 1.85 & 10.85 & 11.78 & 1.43 \\
\hline 917.744 & Max WS & $500-\mathrm{yr}$ & 05May2014 1224 & 29.15 & 253.94 & 255.66 & 2.02 & 14.44 & 13.04 & 1.72 \\
\hline 885.843 & Max WS & $2-\mathrm{yr}$ & 05Мау2014 1242 & 3.29 & 253.61 & 254.29 & 1.24 & 2.65 & 6.37 & 0.68 \\
\hline 885.843 & Max WS & $5-y r$ & 05Мay2014 1236 & 6.3 & 253.61 & 254.48 & 1.57 & 4.01 & 7.5 & 0.87 \\
\hline 885.843 & Max WS & $10-\mathrm{yr}$ & 05May2014 1230 & 9.76 & 253.61 & 254.68 & 1.72 & 5.66 & 8.67 & 1.07 \\
\hline
\end{tabular}




\begin{tabular}{|c|c|c|c|c|c|c|c|c|c|c|}
\hline $\begin{array}{l}\text { River } \\
\text { Sta }\end{array}$ & Profile & Plan & Time of Max & $\begin{array}{c}\mathbf{Q} \\
\text { Total } \\
\left(\mathrm{m}^{3} / \mathbf{s}\right)\end{array}$ & $\begin{array}{c}\text { Min } \\
\text { Ch El } \\
\text { (m) }\end{array}$ & $\begin{array}{l}\text { W.S. } \\
\text { Elev } \\
(\mathrm{m})\end{array}$ & $\begin{array}{l}\text { Vel } \\
\text { Chnl } \\
(\mathbf{m} / \mathbf{s})\end{array}$ & $\begin{array}{l}\text { Flow } \\
\text { Area } \\
\left(\mathbf{m}^{2}\right)\end{array}$ & $\begin{array}{c}\text { Top } \\
\text { Width } \\
\text { (m) }\end{array}$ & $\begin{array}{c}\text { Max Chl } \\
\text { Dpth } \\
\text { (m) }\end{array}$ \\
\hline 885.843 & Max WS & $25-\mathrm{yr}$ & 05Мау2014 1224 & 13.75 & 253.61 & 254.86 & 1.9 & 7.24 & 9.64 & 1.25 \\
\hline 885.843 & Max WS & $50-\mathrm{yr}$ & 05Мау2014 1224 & 16.05 & 253.61 & 254.96 & 1.95 & 8.21 & 10.03 & 1.35 \\
\hline 885.843 & Max WS & $100-\mathrm{yr}$ & 05Мay2014 1224 & 20.05 & 253.61 & 255.11 & 2.05 & 9.77 & 10.63 & 1.5 \\
\hline 885.843 & Max WS & $500-\mathrm{yr}$ & 05Мay2014 1224 & 29.08 & 253.61 & 255.41 & 2.21 & 13.15 & 11.65 & 1.8 \\
\hline 831.018 & Max WS & $2-y r$ & 05Мay2014 1242 & 3.28 & 252.63 & 253.01 & 2.13 & 1.54 & 5.78 & 0.38 \\
\hline 831.018 & Max WS & $5-y r$ & 05Мay2014 1236 & 6.3 & 252.63 & 253.17 & 2.49 & 2.53 & 6.63 & 0.54 \\
\hline 831.018 & Max WS & $10-y r$ & 05Мay2014 1230 & 9.73 & 252.63 & 253.31 & 2.82 & 3.45 & 7.31 & 0.68 \\
\hline 831.018 & Max WS & $25-y r$ & 05Мay2014 1230 & 13.75 & 252.63 & 253.44 & 3.08 & 4.47 & 8 & 0.81 \\
\hline 831.018 & Max WS & $50-\mathrm{yr}$ & 05Мау2014 1224 & 15.95 & 252.63 & 253.49 & 3.25 & 4.9 & 8.27 & 0.86 \\
\hline 831.018 & Max WS & $100-\mathrm{yr}$ & 05Маy2014 1224 & 19.96 & 252.63 & 253.59 & 3.48 & 5.74 & 8.78 & 0.96 \\
\hline 831.018 & Max WS & $500-y r$ & 05Маy2014 1224 & 28.99 & 252.63 & 253.78 & 3.89 & 7.46 & 9.72 & 1.15 \\
\hline 794.448 & Max WS & $2-y r$ & 05Мay2014 1242 & 3.28 & 251.86 & 252.45 & 1 & 3.28 & 7.79 & 0.59 \\
\hline 794.448 & Max WS & $5-y r$ & 05Мау2014 1236 & 6.29 & 251.86 & 252.71 & 1.15 & 5.45 & 9.38 & 0.85 \\
\hline 794.448 & Max WS & $10-\mathrm{yr}$ & 05Мay2014 1230 & 9.71 & 251.86 & 252.87 & 1.36 & 7.12 & 10.43 & 1.01 \\
\hline 794.448 & Max WS & $25-\mathrm{yr}$ & 05Мay2014 1230 & 13.74 & 251.86 & 253.07 & 1.49 & 9.24 & 11.63 & 1.21 \\
\hline 794.448 & Max WS & $50-\mathrm{yr}$ & 05Мay2014 1230 & 15.82 & 251.86 & 253.15 & 1.55 & 10.19 & 12.13 & 1.29 \\
\hline 794.448 & Max WS & $100-\mathrm{yr}$ & 05Мay2014 1224 & 19.88 & 251.86 & 253.28 & 1.68 & 11.82 & 12.89 & 1.42 \\
\hline 794.448 & Max WS & $500-\mathrm{yr}$ & 05Маy2014 1224 & 28.91 & 251.86 & 253.55 & 1.86 & 15.55 & 14.25 & 1.69 \\
\hline 753.27 & Max WS & $2-y r$ & 05Мay2014 1242 & 3.27 & 251.5 & 252.06 & 1.45 & 2.25 & 6.69 & 0.56 \\
\hline 753.27 & Max WS & $5-\mathrm{yr}$ & 05Маy2014 1236 & 6.28 & 251.5 & 252.25 & 1.71 & 3.67 & 8.26 & 0.75 \\
\hline 753.27 & Max WS & $10-\mathrm{yr}$ & 05Мay2014 1230 & 9.68 & 251.5 & 252.39 & 1.99 & 4.87 & 9 & 0.89 \\
\hline 753.27 & Max WS & $25-\mathrm{yr}$ & 05Мay2014 1230 & 13.72 & 251.5 & 252.52 & 2.24 & 6.12 & 9.66 & 1.02 \\
\hline 753.27 & Max WS & $50-\mathrm{yr}$ & 05Мay2014 1224 & 15.76 & 251.5 & 252.59 & 2.31 & 6.81 & 9.99 & 1.09 \\
\hline 753.27 & Max WS & $100-\mathrm{yr}$ & 05Мay2014 1224 & 19.78 & 251.5 & 252.7 & 2.51 & 7.87 & 10.49 & 1.2 \\
\hline 753.27 & Max WS & $500-\mathrm{yr}$ & 05Мay2014 1224 & 28.82 & 251.5 & 252.91 & 2.82 & 10.22 & 11.44 & 1.41 \\
\hline 720.714 & Max WS & $2-y r$ & 05Маy2014 1242 & 3.27 & 251.09 & 251.59 & 1.51 & 2.16 & 7.22 & 0.5 \\
\hline 720.714 & Max WS & $5-\mathrm{yr}$ & 05Мay2014 1236 & 6.27 & 251.09 & 251.76 & 1.82 & 3.45 & 8.43 & 0.67 \\
\hline 720.714 & Max WS & $10-y r$ & 05May2014 1230 & 9.66 & 251.09 & 251.9 & 2.02 & 4.78 & 9.39 & 0.81 \\
\hline 720.714 & Max WS & $25-\mathrm{yr}$ & 05Мay2014 1230 & 13.71 & 251.09 & 252.05 & 2.2 & 6.22 & 10.23 & 0.96 \\
\hline 720.714 & Max WS & $50-\mathrm{yr}$ & 05Мау2014 1230 & 15.81 & 251.09 & 252.12 & 2.27 & 6.95 & 10.63 & 1.03 \\
\hline 720.714 & Max WS & $100-\mathrm{yr}$ & 05Мay2014 1230 & 19.37 & 251.09 & 252.22 & 2.42 & 8.01 & 11.19 & 1.13 \\
\hline 720.714 & Max WS & $500-\mathrm{yr}$ & 05Мау2014 1224 & 28.75 & 251.09 & 252.43 & 2.75 & 10.45 & 12.37 & 1.34 \\
\hline 673.556 & Max WS & $2-y r$ & 05Мау2014 1248 & 3.21 & 250.52 & 251.27 & 0.37 & 8.63 & 17.66 & 0.75 \\
\hline 673.556 & Max WS & $5-\mathrm{yr}$ & 05Маy2014 1236 & 6.23 & 250.52 & 251.47 & 0.5 & 12.55 & 20.84 & 0.95 \\
\hline 673.556 & Max WS & $10-\mathrm{yr}$ & 05Мay2014 1230 & 9.56 & 250.52 & 251.65 & 0.58 & 16.48 & 23.57 & 1.13 \\
\hline
\end{tabular}




\begin{tabular}{|c|c|c|c|c|c|c|c|c|c|c|}
\hline $\begin{array}{l}\text { River } \\
\text { Sta }\end{array}$ & Profile & Plan & Time of Max & $\begin{array}{c}\text { Q } \\
\text { Total } \\
\left(\mathbf{m}^{3} / \mathbf{s}\right) \\
\end{array}$ & $\begin{array}{c}\text { Min } \\
\text { Ch El } \\
\text { (m) }\end{array}$ & $\begin{array}{l}\text { W.S. } \\
\text { Elev } \\
(\mathbf{m})\end{array}$ & $\begin{array}{c}\text { Vel } \\
\text { Chnl } \\
(\mathbf{m} / \mathbf{s})\end{array}$ & $\begin{array}{l}\text { Flow } \\
\text { Area } \\
\left(\mathbf{m}^{2}\right)\end{array}$ & $\begin{array}{c}\text { Top } \\
\text { Width } \\
(\mathbf{m}) \\
\end{array}$ & $\begin{array}{c}\text { Max Chl } \\
\text { Dpth } \\
(\mathbf{m}) \\
\end{array}$ \\
\hline 673.556 & Max WS & $25-y r$ & 05May2014 1230 & 13.64 & 250.52 & 251.84 & 0.64 & 21.33 & 26.68 & 1.32 \\
\hline 673.556 & Max WS & $50-y r$ & 05May2014 1230 & 15.75 & 250.52 & 251.92 & 0.67 & 23.55 & 28.08 & 1.4 \\
\hline 673.556 & Max WS & $100-y r$ & 05May2014 1230 & 19.36 & 250.52 & 252.04 & 0.72 & 27.01 & 30.24 & 1.52 \\
\hline 673.556 & Max WS & $500-y r$ & 05May2014 1224 & 28.48 & 250.52 & 252.28 & 0.82 & 34.85 & 34.42 & 1.76 \\
\hline 625.562 & Max WS & $2-y r$ & 05May2014 1248 & 3.21 & 250.47 & 251.2 & 0.62 & 5.17 & 11.39 & 0.73 \\
\hline 625.562 & Max WS & $5-\mathrm{yr}$ & 05May2014 1236 & 6.18 & 250.47 & 251.37 & 0.85 & 7.26 & 12.92 & 0.9 \\
\hline 625.562 & Max WS & $10-\mathrm{yr}$ & 05May2014 1230 & 9.43 & 250.47 & 251.52 & 1.02 & 9.29 & 14.4 & 1.05 \\
\hline 625.562 & Max WS & $25-\mathrm{yr}$ & 05May2014 1230 & 13.56 & 250.47 & 251.71 & 1.1 & 12.29 & 16.8 & 1.24 \\
\hline 625.562 & Max WS & $50-\mathrm{yr}$ & 05May2014 1230 & 15.67 & 250.47 & 251.79 & 1.16 & 13.54 & 17.7 & 1.32 \\
\hline 625.562 & Max WS & $100-y r$ & 05Мay2014 1230 & 19.33 & 250.47 & 251.9 & 1.25 & 15.56 & 19.24 & 1.43 \\
\hline 625.562 & Max WS & $500-y r$ & 05Мay2014 1224 & 28.12 & 250.47 & 252.13 & 1.41 & 20.5 & 23.62 & 1.66 \\
\hline 582.64 & Max WS & $2-\mathrm{yr}$ & 05Мay2014 1248 & 3.2 & 250.01 & 250.47 & 1.59 & 2.02 & 8.7 & 0.46 \\
\hline 582.64 & Max WS & $5-y r$ & 05May2014 1236 & 6.15 & 250.01 & 250.57 & 2.08 & 2.96 & 9.86 & 0.56 \\
\hline 582.64 & Max WS & $10-\mathrm{yr}$ & 05Мay2014 1236 & 9.42 & 250.01 & 250.68 & 2.25 & 4.18 & 11.37 & 0.67 \\
\hline 582.64 & Max WS & $25-\mathrm{yr}$ & 05Мay2014 1230 & 13.51 & 250.01 & 250.79 & 2.47 & 5.47 & 13.3 & 0.78 \\
\hline 582.64 & Max WS & $50-\mathrm{yr}$ & 05May2014 1230 & 15.63 & 250.01 & 250.82 & 2.65 & 5.9 & 13.89 & 0.81 \\
\hline 582.64 & Max WS & $100-y r$ & 05May2014 1230 & 19.31 & 250.01 & 250.88 & 2.89 & 6.68 & 14.86 & 0.87 \\
\hline 582.64 & Max WS & $500-\mathrm{yr}$ & 05May2014 1224 & 27.95 & 250.01 & 251 & 3.26 & 8.74 & 18.5 & 0.99 \\
\hline 543.04 & Max WS & $2-y r$ & 05Мay2014 1248 & 3.2 & 249.4 & 249.94 & 0.66 & 4.82 & 14.89 & 0.54 \\
\hline 543.04 & Max WS & $5-\mathrm{yr}$ & 05May2014 1236 & 6.13 & 249.4 & 250.06 & 0.91 & 6.74 & 16.86 & 0.66 \\
\hline 543.04 & Max WS & $10-\mathrm{yr}$ & 05Мay2014 1236 & 9.41 & 249.4 & 250.23 & 0.98 & 9.7 & 19.38 & 0.83 \\
\hline 543.04 & Max WS & $25-\mathrm{yr}$ & 05Мay2014 1230 & 13.47 & 249.4 & 250.3 & 1.22 & 11.15 & 20.54 & 0.9 \\
\hline 543.04 & Max WS & $50-\mathrm{yr}$ & 05Мay2014 1230 & 15.61 & 249.4 & 250.33 & 1.34 & 11.83 & 21.02 & 0.93 \\
\hline 543.04 & Max WS & $100-\mathrm{yr}$ & 05May2014 1230 & 19.31 & 249.4 & 250.39 & 1.52 & 13.04 & 21.87 & 0.99 \\
\hline 543.04 & Max WS & $500-y r$ & 05May2014 1224 & 27.85 & 249.4 & 250.52 & 1.81 & 15.99 & 23.71 & 1.12 \\
\hline 496.118 & Max WS & $2-\mathrm{yr}$ & 05Мay2014 1248 & 3.19 & 249.1 & 249.89 & 0.28 & 11.26 & 25.97 & 0.79 \\
\hline 496.118 & Max WS & $5-\mathrm{yr}$ & 05May2014 1236 & 6.09 & 249.1 & 249.98 & 0.44 & 13.86 & 28.49 & 0.88 \\
\hline 496.118 & Max WS & $10-\mathrm{yr}$ & 05Мay2014 1236 & 9.37 & 249.1 & 250.16 & 0.48 & 19.49 & 33.68 & 1.06 \\
\hline 496.118 & Max WS & $25-\mathrm{yr}$ & 05May2014 1230 & 13.42 & 249.1 & 250.22 & 0.63 & 21.42 & 35.29 & 1.12 \\
\hline 496.118 & Max WS & $50-y r$ & 05May2014 1224 & 14.58 & 249.1 & 250.24 & 0.66 & 22.28 & 35.99 & 1.14 \\
\hline 496.118 & Max WS & $100-y r$ & 05May2014 1224 & 18.72 & 249.1 & 250.29 & 0.8 & 23.89 & 37.05 & 1.19 \\
\hline 496.118 & Max WS & $500-\mathrm{yr}$ & 05May2014 1224 & 27.67 & 249.1 & 250.41 & 1 & 28.56 & 40.26 & 1.31 \\
\hline 428.594 & Max WS & $2-\mathrm{yr}$ & 05Мay2014 1248 & 3.17 & 248.79 & 249.04 & 1.74 & 1.82 & 13.45 & 0.25 \\
\hline 428.594 & Max WS & $5-\mathrm{yr}$ & 05May2014 1242 & 6.09 & 248.79 & 249.15 & 1.67 & 3.64 & 19.22 & 0.36 \\
\hline 428.594 & Max WS & $10-y r$ & 05May2014 1236 & 9.29 & 248.79 & 249.25 & 1.62 & 5.81 & 24.12 & 0.46 \\
\hline
\end{tabular}




\begin{tabular}{|c|c|c|c|c|c|c|c|c|c|c|}
\hline $\begin{array}{c}\text { River } \\
\text { Sta }\end{array}$ & Profile & Plan & Time of Max & $\begin{array}{c}Q \\
\text { Total } \\
\left(\mathrm{m}^{3} / \mathrm{s}\right)\end{array}$ & $\begin{array}{c}\text { Min } \\
\text { Ch El } \\
(\mathbf{m})\end{array}$ & $\begin{array}{l}\text { W.S. } \\
\text { Elev } \\
(\mathbf{m})\end{array}$ & $\begin{array}{c}\text { Vel } \\
\text { Chnl } \\
(\mathrm{m} / \mathrm{s})\end{array}$ & $\begin{array}{l}\text { Flow } \\
\text { Area } \\
\left(\mathbf{m}^{2}\right)\end{array}$ & $\begin{array}{c}\text { Top } \\
\text { Width } \\
\text { (m) }\end{array}$ & $\begin{array}{c}\text { Max Chl } \\
\text { Dpth } \\
\text { (m) }\end{array}$ \\
\hline 428.594 & Max WS & $25-\mathrm{yr}$ & 05Мay2014 1230 & 13.31 & 248.79 & 249.3 & 1.93 & 7.1 & 26.24 & 0.51 \\
\hline 428.594 & Max WS & $50-\mathrm{yr}$ & 05May2014 1230 & 15.56 & 248.79 & 249.33 & 2.04 & 7.94 & 27.56 & 0.54 \\
\hline 428.594 & Max WS & $100-y r$ & 05May2014 1230 & 19.27 & 248.79 & 249.38 & 2.16 & 9.38 & 29.46 & 0.59 \\
\hline 428.594 & Max WS & $500-y r$ & 05May2014 1230 & 27.9 & 248.79 & 249.5 & 2.29 & 13.18 & 34.33 & 0.71 \\
\hline 389.142 & Max WS & $2-\mathrm{yr}$ & 05May2014 1254 & 3.14 & 248.21 & 248.52 & 0.94 & 4.11 & 27.57 & 0.31 \\
\hline 389.142 & Max WS & $5-y r$ & 05May2014 1242 & 6.07 & 248.21 & 248.67 & 0.82 & 8.63 & 32.61 & 0.46 \\
\hline 389.142 & Max WS & $10-\mathrm{yr}$ & 05May2014 1236 & 9.23 & 248.21 & 248.76 & 0.9 & 11.76 & 35.37 & 0.55 \\
\hline 389.142 & Max WS & $25-\mathrm{yr}$ & 05May2014 1236 & 13.1 & 248.21 & 248.87 & 0.95 & 15.87 & 38.24 & 0.66 \\
\hline 389.142 & Max WS & $50-y r$ & 05May2014 1230 & 15.42 & 248.21 & 248.93 & 0.99 & 17.98 & 39.53 & 0.72 \\
\hline 389.142 & Max WS & $100-y r$ & 05May2014 1230 & 19.17 & 248.21 & 249.01 & 1.03 & 21.53 & 41.67 & 0.8 \\
\hline 389.142 & Max WS & $500-y r$ & 05May2014 1230 & 27.82 & 248.21 & 249.19 & 1.13 & 28.94 & 45.48 & 0.98 \\
\hline 343.978 & Max WS & $2-y r$ & 05May2014 1254 & 3.12 & 247.75 & 248.19 & 0.65 & 4.79 & 16.04 & 0.44 \\
\hline 343.978 & Max WS & $5-y r$ & 05Мay2014 1242 & 5.99 & 247.75 & 248.33 & 0.84 & 7.16 & 19.14 & 0.58 \\
\hline 343.978 & Max WS & $10-\mathrm{yr}$ & 05May2014 1242 & 9.03 & 247.75 & 248.46 & 0.92 & 9.88 & 22.31 & 0.71 \\
\hline 343.978 & Max WS & $25-\mathrm{yr}$ & 05May2014 1236 & 13.05 & 247.75 & 248.58 & 1.05 & 12.8 & 25.35 & 0.83 \\
\hline 343.978 & Max WS & $50-\mathrm{yr}$ & 05May2014 1236 & 15.06 & 247.75 & 248.63 & 1.11 & 14.02 & 26.43 & 0.88 \\
\hline 343.978 & Max WS & $100-y r$ & 05May2014 1230 & 18.86 & 247.75 & 248.72 & 1.21 & 16.42 & 28.47 & 0.97 \\
\hline 343.978 & Max WS & $500-y r$ & 05May2014 1230 & 27.57 & 247.75 & 248.89 & 1.37 & 21.79 & 32.62 & 1.14 \\
\hline 318.111 & Max WS & $2-y r$ & 05May2014 1254 & 3.11 & 247.65 & 248.08 & 0.78 & 3.98 & 14.42 & 0.43 \\
\hline 318.111 & Max WS & $5-\mathrm{yr}$ & 05May2014 1242 & 5.97 & 247.65 & 248.21 & 0.99 & 6.03 & 17.23 & 0.56 \\
\hline 318.111 & Max WS & $10-\mathrm{yr}$ & 05May2014 1242 & 9.03 & 247.65 & 248.34 & 1.05 & 8.59 & 20.48 & 0.69 \\
\hline 318.111 & Max WS & $25-\mathrm{yr}$ & 05May2014 1236 & 13.03 & 247.65 & 248.46 & 1.19 & 11.1 & 23.07 & 0.81 \\
\hline 318.111 & Max WS & $50-y r$ & 05May2014 1236 & 15.05 & 247.65 & 248.5 & 1.26 & 12.16 & 24.06 & 0.85 \\
\hline 318.111 & Max WS & $100-\mathrm{yr}$ & 05May2014 1230 & 18.77 & 247.65 & 248.59 & 1.36 & 14.33 & 26.01 & 0.94 \\
\hline 318.111 & Max WS & $500-\mathrm{yr}$ & 05May2014 1230 & 27.5 & 247.65 & 248.76 & 1.54 & 19.05 & 29.78 & 1.11 \\
\hline 284.899 & Max WS & $2-\mathrm{yr}$ & 05May2014 1254 & 3.1 & 247.49 & 247.94 & 0.67 & 4.6 & 15.78 & 0.45 \\
\hline 284.899 & Max WS & $5-\mathrm{yr}$ & 05May2014 1242 & 5.95 & 247.49 & 248.07 & 0.88 & 6.75 & 18.86 & 0.58 \\
\hline 284.899 & Max WS & $10-\mathrm{yr}$ & 05May2014 1242 & 9.02 & 247.49 & 248.21 & 0.92 & 9.8 & 22.55 & 0.72 \\
\hline 284.899 & Max WS & $25-\mathrm{yr}$ & 05May2014 1236 & 13 & 247.49 & 248.33 & 1.03 & 12.68 & 25.28 & 0.84 \\
\hline 284.899 & Max WS & $50-\mathrm{yr}$ & 05May2014 1236 & 15.04 & 247.49 & 248.38 & 1.09 & 13.85 & 26.29 & 0.89 \\
\hline 284.899 & Max WS & $100-y r$ & 05May2014 1230 & 18.65 & 247.49 & 248.47 & 1.14 & 16.43 & 28.28 & 0.98 \\
\hline 284.899 & Max WS & $500-\mathrm{yr}$ & 05May2014 1230 & 27.41 & 247.49 & 248.65 & 1.29 & 21.81 & 32.39 & 1.16 \\
\hline 244.681 & Max WS & $2-\mathrm{yr}$ & 05May2014 1300 & 3.07 & 247.05 & 247.48 & 1.01 & 3.06 & 11.5 & 0.43 \\
\hline 244.681 & Max WS & $5-\mathrm{yr}$ & 05May2014 1248 & 5.91 & 247.05 & 247.64 & 1.15 & 5.13 & 14.22 & 0.59 \\
\hline 244.681 & Max WS & $10-\mathrm{yr}$ & 05May2014 1242 & 8.99 & 247.05 & 247.77 & 1.26 & 7.11 & 16.76 & 0.72 \\
\hline
\end{tabular}




\begin{tabular}{|c|c|c|c|c|c|c|c|c|c|c|}
\hline $\begin{array}{c}\text { River } \\
\text { Sta }\end{array}$ & Profile & Plan & Time of Max & $\begin{array}{c}\mathbf{Q} \\
\text { Total } \\
\left(\mathrm{m}^{3} / \mathbf{s}\right)\end{array}$ & $\begin{array}{c}\text { Min } \\
\text { Ch El } \\
(\mathbf{m})\end{array}$ & $\begin{array}{l}\text { W.S. } \\
\text { Elev } \\
(\mathbf{m})\end{array}$ & $\begin{array}{c}\text { Vel } \\
\text { Chnl } \\
(\mathrm{m} / \mathrm{s})\end{array}$ & $\begin{array}{l}\text { Flow } \\
\text { Area } \\
\left(\mathbf{m}^{2}\right)\end{array}$ & $\begin{array}{c}\text { Top } \\
\text { Width } \\
\text { (m) }\end{array}$ & $\begin{array}{c}\text { Max Chl } \\
\text { Dpth } \\
\text { (m) }\end{array}$ \\
\hline 244.681 & Max WS & $25-\mathrm{yr}$ & 05May2014 1236 & 12.91 & 247.05 & 247.89 & 1.39 & 9.26 & 19.14 & 0.84 \\
\hline 244.681 & Max WS & $50-\mathrm{yr}$ & 05May2014 1236 & 14.97 & 247.05 & 247.96 & 1.4 & 10.71 & 20.7 & 0.91 \\
\hline 244.681 & Max WS & $100-y r$ & 05May2014 1236 & 18.41 & 247.05 & 248.06 & 1.45 & 12.69 & 22.73 & 1.01 \\
\hline 244.681 & Max WS & $500-y r$ & 05May2014 1230 & 27.17 & 247.05 & 248.21 & 1.65 & 16.46 & 26.37 & 1.16 \\
\hline 214.499 & Max WS & $2-y r$ & 05Мay2014 1300 & 3.07 & 246.61 & 247.38 & 0.33 & 9.32 & 20.5 & 0.77 \\
\hline 214.499 & Max WS & $5-\mathrm{yr}$ & 05May2014 1248 & 5.89 & 246.61 & 247.57 & 0.43 & 13.72 & 24.79 & 0.96 \\
\hline 214.499 & Max WS & $10-\mathrm{yr}$ & 05Мay2014 1242 & 8.96 & 246.61 & 247.7 & 0.53 & 17.07 & 27.7 & 1.09 \\
\hline 214.499 & Max WS & $25-\mathrm{yr}$ & 05May2014 1236 & 12.84 & 246.61 & 247.83 & 0.64 & 20.83 & 30.42 & 1.22 \\
\hline 214.499 & Max WS & $50-y r$ & 05Мay2014 1236 & 14.9 & 246.61 & 247.91 & 0.67 & 23.4 & 32.19 & 1.3 \\
\hline 214.499 & Max WS & $100-\mathrm{yr}$ & 05Мay2014 1236 & 18.38 & 246.61 & 248 & 0.73 & 26.52 & 34.44 & 1.39 \\
\hline 214.499 & Max WS & $500-\mathrm{yr}$ & 05May2014 1230 & 27.03 & 246.61 & 248.17 & 0.91 & 32.36 & 38.25 & 1.56 \\
\hline 214.498 & Max WS & $2-y r$ & 05Мay2014 1300 & 3.06 & 246.61 & 246.96 & 1.17 & 2.61 & 11.81 & 0.35 \\
\hline 214.498 & Max WS & $5-\mathrm{yr}$ & 05Маy2014 1248 & 5.86 & 246.61 & 247.1 & 1.31 & 4.46 & 14.5 & 0.49 \\
\hline 214.498 & Max WS & $10-\mathrm{yr}$ & 05May2014 1242 & 8.9 & 246.61 & 247.19 & 1.53 & 5.81 & 16.35 & 0.58 \\
\hline 214.498 & Max WS & $25-\mathrm{yr}$ & 05May2014 1236 & 12.67 & 246.61 & 247.3 & 1.63 & 7.77 & 18.78 & 0.69 \\
\hline 214.498 & Max WS & $50-\mathrm{yr}$ & 05May2014 1236 & 14.76 & 246.61 & 247.35 & 1.69 & 8.74 & 19.85 & 0.74 \\
\hline 214.498 & Max WS & $100-\mathrm{yr}$ & 05Мay2014 1236 & 18.33 & 246.61 & 247.41 & 1.83 & 10.01 & 21.24 & 0.8 \\
\hline 214.498 & Max WS & $500-\mathrm{yr}$ & 05May2014 1230 & 26.75 & 246.61 & 247.54 & 2.07 & 12.92 & 24.08 & 0.93 \\
\hline 147.881 & Max WS & $2-y r$ & 05May2014 1300 & 3.06 & 245.82 & 246.17 & 1.25 & 2.44 & 11.51 & 0.35 \\
\hline 147.881 & Max WS & $5-\mathrm{yr}$ & 05Мay2014 1248 & 5.83 & 245.82 & 246.33 & 1.3 & 4.48 & 14.34 & 0.51 \\
\hline 147.881 & Max WS & $10-\mathrm{yr}$ & 05Мay2014 1242 & 8.85 & 245.82 & 246.44 & 1.43 & 6.18 & 16.6 & 0.62 \\
\hline 147.881 & Max WS & $25-\mathrm{yr}$ & 05 May2014 1242 & 12.49 & 245.82 & 246.58 & 1.43 & 8.75 & 19.46 & 0.76 \\
\hline 147.881 & Max WS & $50-y r$ & 05May2014 1236 & 14.65 & 245.82 & 246.63 & 1.5 & 9.78 & 20.62 & 0.81 \\
\hline 147.881 & Max WS & $100-y r$ & 05May2014 1236 & 18.27 & 245.82 & 246.73 & 1.54 & 11.83 & 22.55 & 0.91 \\
\hline 147.881 & Max WS & $500-y r$ & 05May2014 1236 & 26.52 & 245.82 & 246.92 & 1.6 & 16.61 & 26.61 & 1.1 \\
\hline 79.942 & Max WS & $2-\mathrm{yr}$ & 05Мay2014 1300 & 3.04 & 245.12 & 245.66 & 0.8 & 3.81 & 11.07 & 0.54 \\
\hline 79.942 & Max WS & $5-\mathrm{yr}$ & 05May2014 1248 & 5.8 & 245.12 & 245.86 & 0.92 & 6.28 & 13.61 & 0.74 \\
\hline 79.942 & Max WS & $10-\mathrm{yr}$ & 05May2014 1242 & 8.77 & 245.12 & 246.01 & 1.04 & 8.46 & 15.59 & 0.89 \\
\hline 79.942 & Max WS & $25-\mathrm{yr}$ & 05May2014 1242 & 12.47 & 245.12 & 246.18 & 1.1 & 11.35 & 17.85 & 1.06 \\
\hline 79.942 & Max WS & $50-y r$ & 05May2014 1242 & 14.34 & 245.12 & 246.25 & 1.14 & 12.61 & 18.83 & 1.13 \\
\hline 79.942 & Max WS & $100-y r$ & 05May2014 1236 & 18.16 & 245.12 & 246.38 & 1.2 & 15.08 & 20.76 & 1.26 \\
\hline 79.942 & Max WS & $500-y r$ & 05Мay2014 1236 & 26.47 & 245.12 & 246.62 & 1.29 & 20.63 & 24.37 & 1.5 \\
\hline 53.415 & Max WS & $2-\mathrm{yr}$ & 05May2014 1300 & 3.04 & 244.76 & 245.13 & 1.9 & 1.6 & 6.65 & 0.37 \\
\hline 53.415 & Max WS & $5-\mathrm{yr}$ & 05Мay2014 1248 & 5.78 & 244.76 & 245.27 & 2.17 & 2.67 & 8.05 & 0.51 \\
\hline 53.415 & Max WS & $10-\mathrm{yr}$ & 05Мay2014 1248 & 8.74 & 244.76 & 245.37 & 2.46 & 3.55 & 8.98 & 0.61 \\
\hline
\end{tabular}




\begin{tabular}{|c|c|c|c|c|c|c|c|c|c|c|}
\hline $\begin{array}{l}\text { River } \\
\text { Sta }\end{array}$ & Profile & Plan & Time of Max & $\begin{array}{c}\mathbf{Q} \\
\text { Total } \\
\left(\mathbf{m}^{3} / \mathbf{s}\right)\end{array}$ & $\begin{array}{c}\text { Min } \\
\text { Ch El } \\
(\mathbf{m})\end{array}$ & $\begin{array}{l}\text { W.S. } \\
\text { Elev } \\
\text { (m) }\end{array}$ & $\begin{array}{l}\text { Vel } \\
\text { Chnl } \\
(\mathbf{m} / \mathbf{s})\end{array}$ & $\begin{array}{l}\text { Flow } \\
\text { Area } \\
\left(\mathbf{m}^{2}\right)\end{array}$ & $\begin{array}{c}\text { Top } \\
\text { Width } \\
\text { (m) }\end{array}$ & $\begin{array}{c}\text { Max Chl } \\
\text { Dpth } \\
\text { (m) }\end{array}$ \\
\hline 53.415 & Max WS & $25-y r$ & 05Мау2014 1242 & 12.46 & 244.76 & 245.5 & 2.63 & 4.74 & 10.05 & 0.74 \\
\hline 53.415 & Max WS & $50-\mathrm{yr}$ & 05May2014 1236 & 14.43 & 244.76 & 245.55 & 2.74 & 5.26 & 10.48 & 0.79 \\
\hline 53.415 & Max WS & $100-\mathrm{yr}$ & 05Маy2014 1236 & 18.12 & 244.76 & 245.62 & 2.99 & 6.07 & 11.12 & 0.87 \\
\hline 53.415 & Max WS & $500-\mathrm{yr}$ & 05Мay2014 1236 & 26.45 & 244.76 & 245.79 & 3.3 & 8.02 & 12.52 & 1.03 \\
\hline 13.63 & Max WS & $2-y r$ & 05Маy2014 1300 & 3.03 & 243.93 & 244.35 & 1.34 & 2.26 & 7.82 & 0.42 \\
\hline 13.63 & Max WS & $5-y r$ & 05Мау2014 1248 & 5.77 & 243.93 & 244.5 & 1.62 & 3.57 & 9.17 & 0.57 \\
\hline 13.63 & Max WS & $10-\mathrm{yr}$ & 05Мay2014 1248 & 8.74 & 243.93 & 244.63 & 1.82 & 4.8 & 10.25 & 0.7 \\
\hline 13.63 & Max WS & $25-\mathrm{yr}$ & 05Мау2014 1242 & 12.45 & 243.93 & 244.76 & 2.01 & 6.21 & 11.36 & 0.83 \\
\hline 13.63 & Max WS & $50-\mathrm{yr}$ & 05Мay2014 1236 & 14.37 & 243.93 & 244.82 & 2.08 & 6.9 & 11.87 & 0.89 \\
\hline 13.63 & Max WS & $100-\mathrm{yr}$ & 05Мay2014 1236 & 18.09 & 243.93 & 244.92 & 2.22 & 8.15 & 12.74 & 0.99 \\
\hline 13.63 & Max WS & $500-y r$ & 05Мay2014 1236 & 26.43 & 243.93 & 245.12 & 2.45 & 10.8 & 14.55 & 1.19 \\
\hline
\end{tabular}




\section{Appendix C - Steady Longtudinal Profiles, 2-, 100-, and 500-yr}

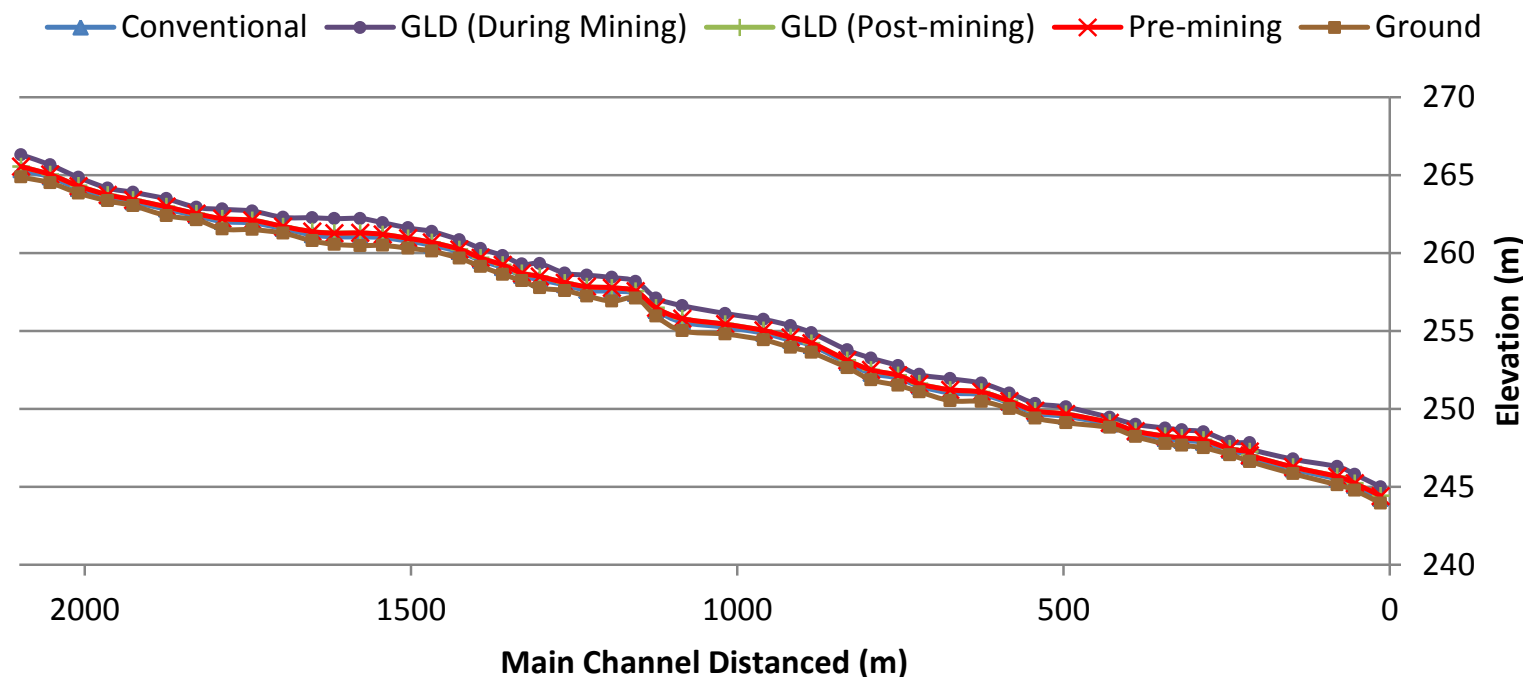

Figure 52: Steady 2-yr water surface longitudinal profile

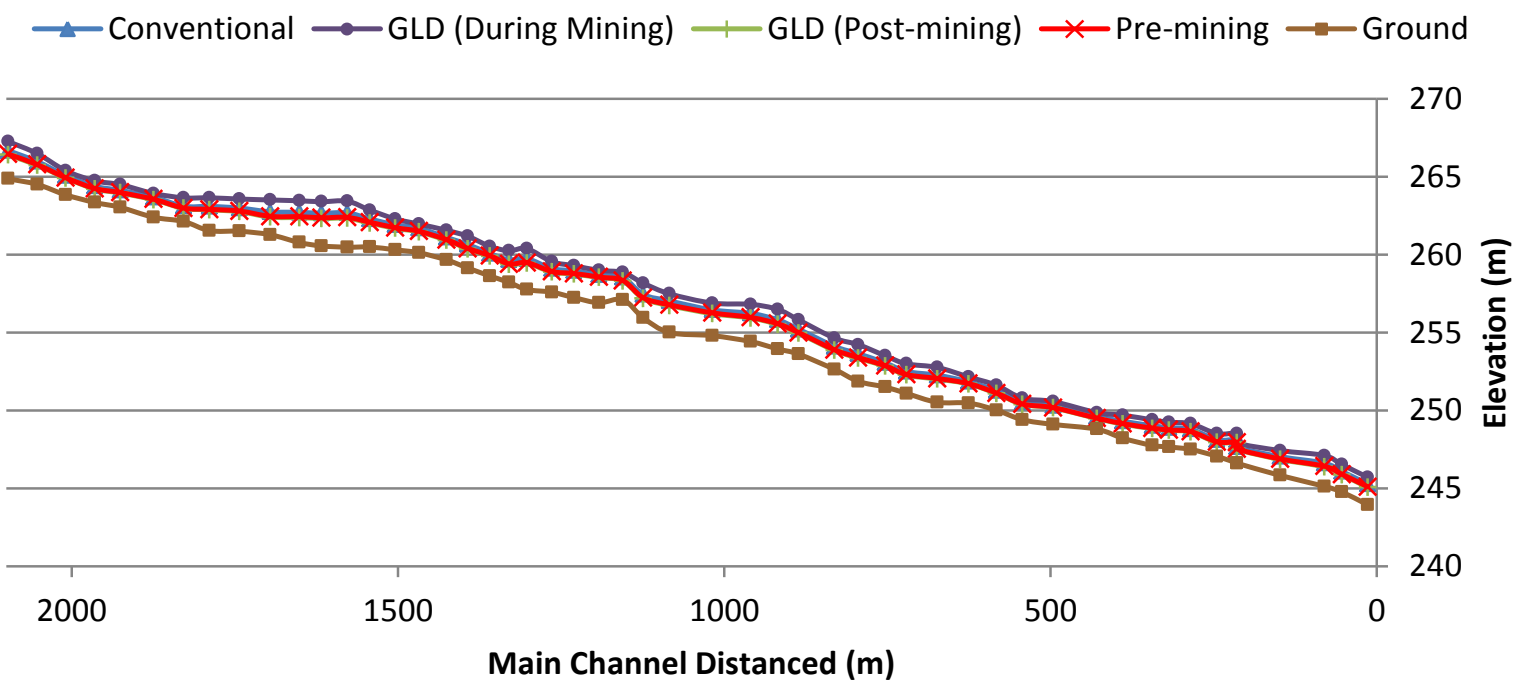

Figure 53: Steady 100-yr water surface longitudinal profile 


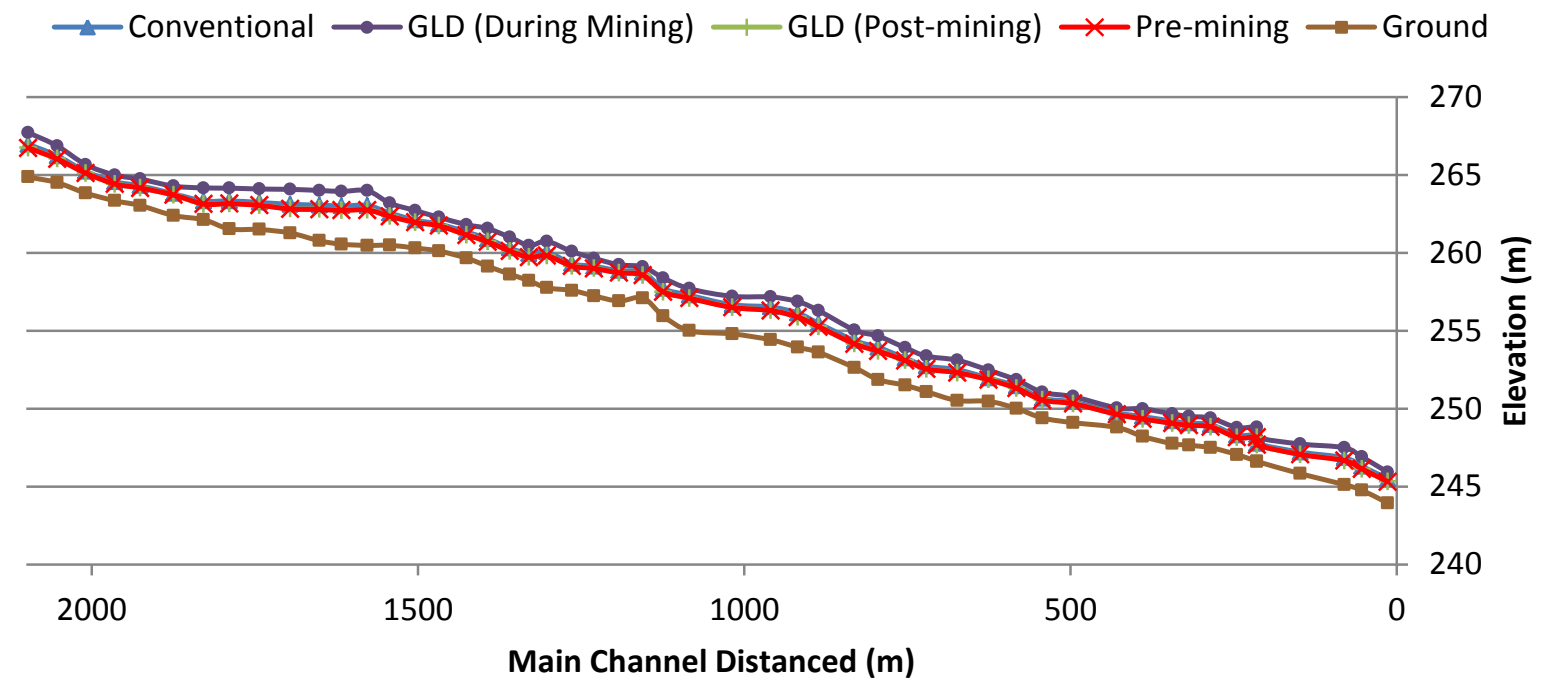

Figure 54: Steady 500-yr water surface longitudinal profile

Unsteady Max WS Longitudinal Profiles, 5-, 10-, and 25-yr

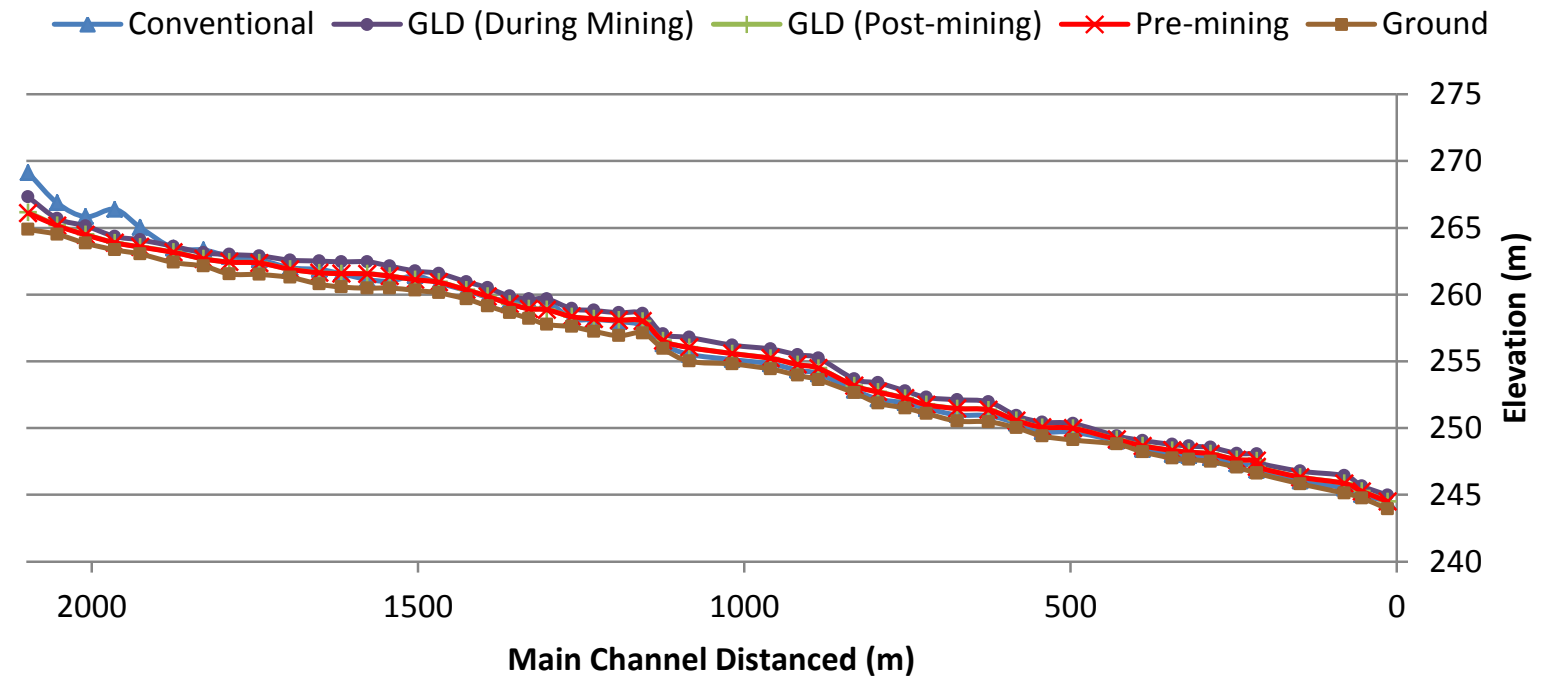

Figure 55: Unsteady 5-yr water surface longitudinal profile 


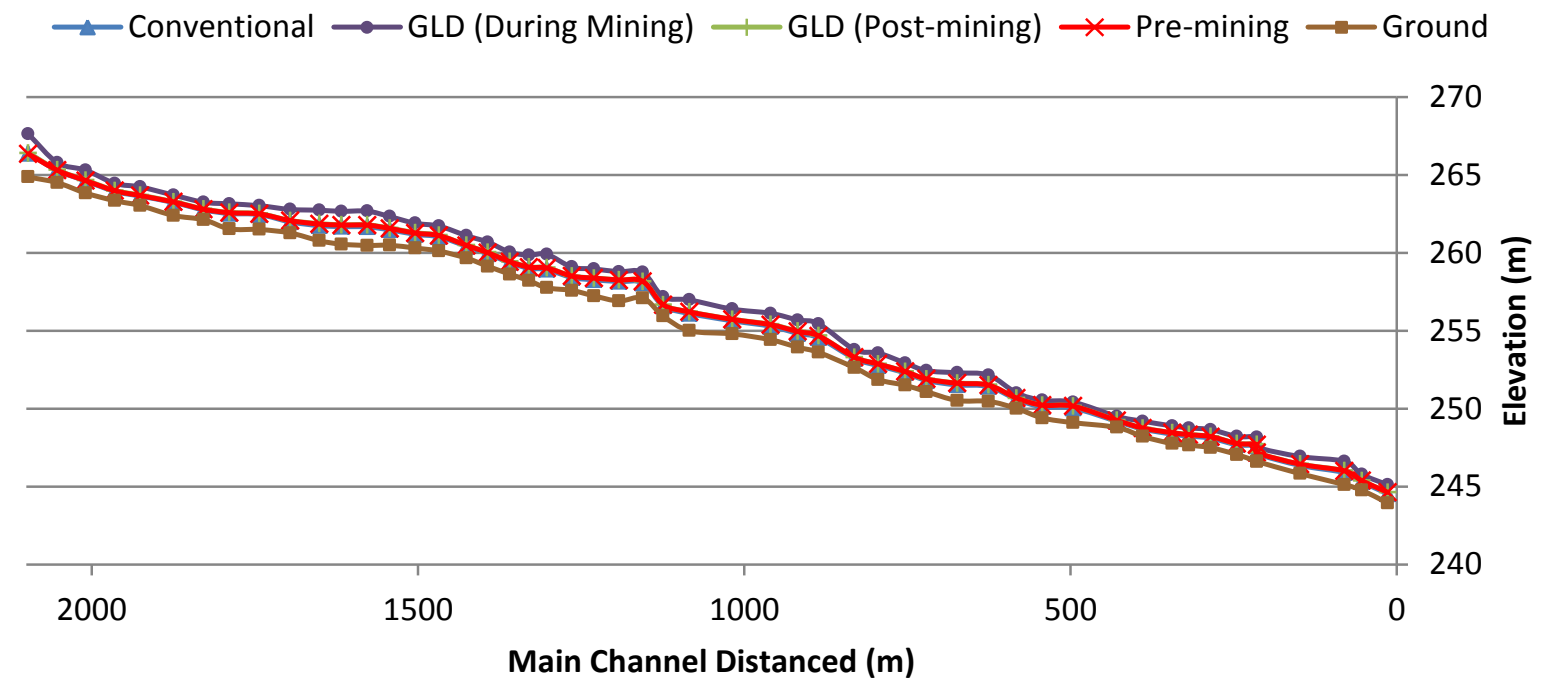

Figure 56: Unsteady 10-yr water surface longitudinal profile

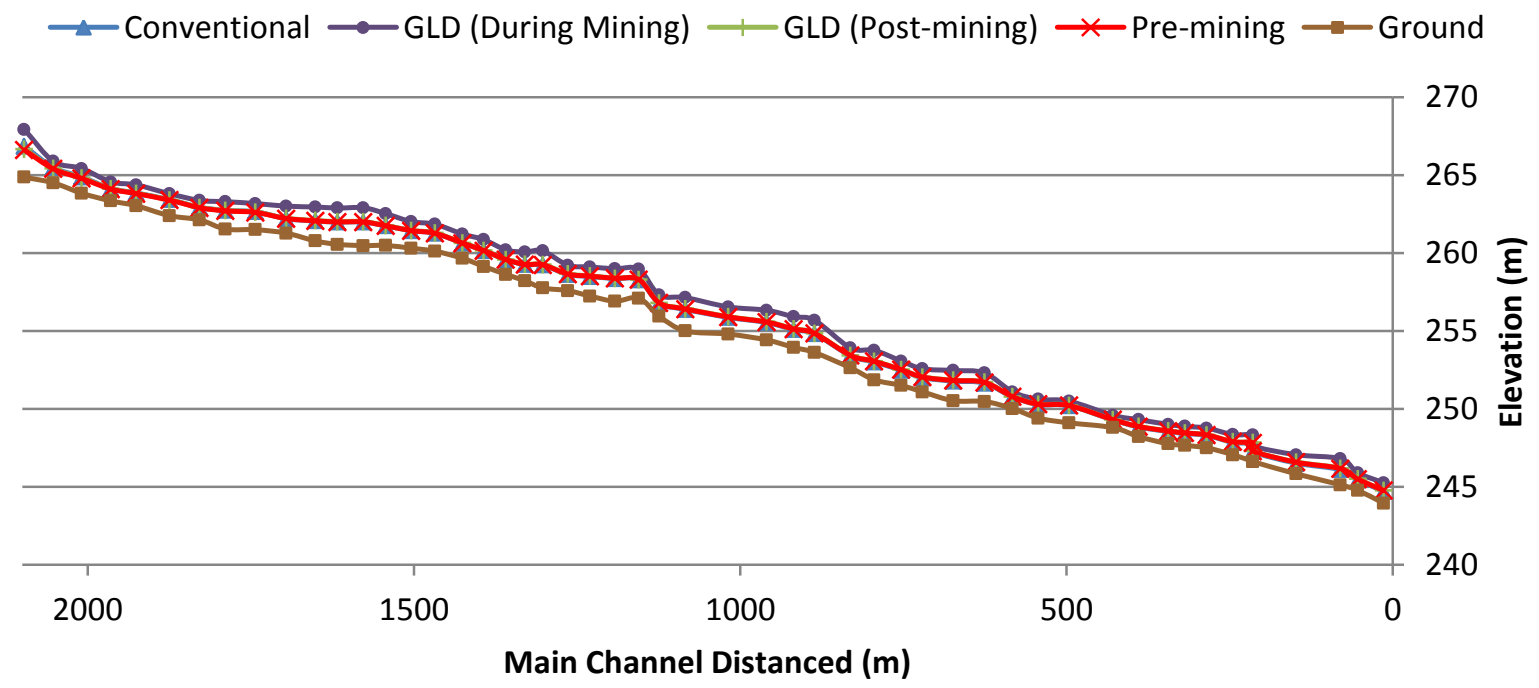

Figure 57: Unsteady 25-yr water surface longitudinal profile 